\title{
FIGHIING THE INSECTS
}

THE STORT OD AN ENT OMOLOGIST

\section{0. HOWARD}



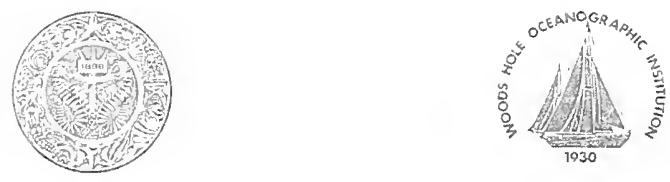

MBL/WHOI LIBRARI

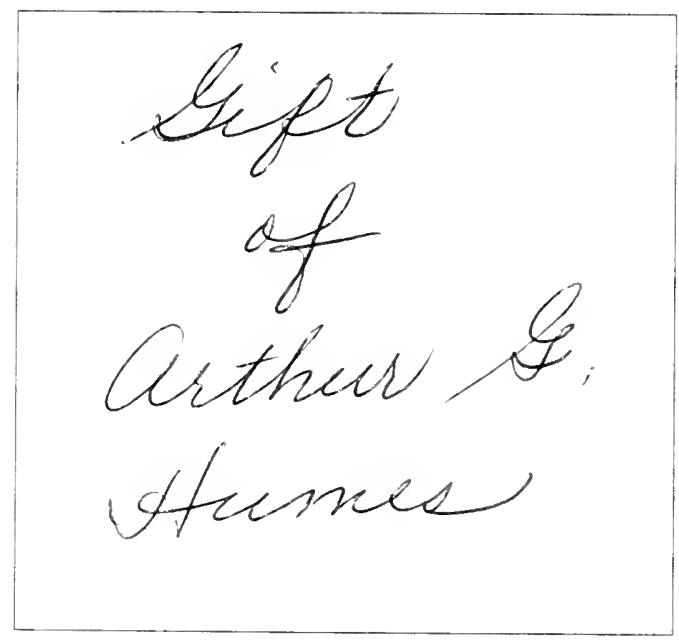




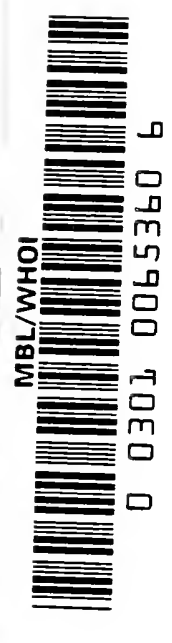



FIGHTING THE INSECTS

THE STORY OF AN ENTOMOLOGIST 


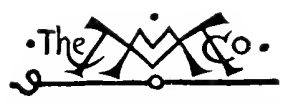

THE MACMILLAN COMPANY

NEW YORK - BOSTON - CHICAGO - DALLAS

ATLANTA - SAN FRANCISCO

MACMILLAN \& CO., Limited

LONDON - BOMBAY - CALCUTTA MELBOURNE

THE MACMILLAN COMPANY

OF CANADA, LIMITED

TORONTO 


\title{
FIGHTING THE INSECTS \\ THE STORY OF A N EN T OMOLOGIST
}

\section{Telling of the Life and Experiences of the Writer}

\author{
By \\ L. O. HOWARD
}

$\frac{\text { New York } \cdot 1933}{\text { THE MACMILLAN COMPANY }}$ 
Copyright, 1933, by

THE MACMILLAN COMPANY.

All rights reserved-no part of this book may be reproduced in any form without permission in writing from the publisher, except by a reviewer who wishes to quote brief passages in connection with a review written for inclusion in magazine or newspaper.

Set $u p$ and printed.

PUBLISHED FEBRUARY, 1933. 


\section{Introduction}

F

IFTEEN years ago I used my spare time for several weeks in writing about thirty thousand words in which I gave a sort of record of my life, but this was my personal story and I did it for my daughters' reading. It so happened that once my mother wrote, largely from her mother's dictation, the story of her mother's life, and that later she wrote a long account of her own. So this little story of mine, added to the two that my mother did, carries the personal records and family incidents through three generations, covering considerably more than a hundred years, since my grandmother was born in 1800 . There are a lot of things in the three stories that might be of interest to others, and if anyone wishes to consult these manuscripts for historical or other reasons, I am sure that my daughters will be very willing.

And now there comes a somewhat imaginative publisher who thinks that "The Story of an Entomologist" might be done in a very readable way. He has evidently read about some of the big and interesting things that have been done by entomologists and that have come from the study of insects by men who have devoted their lives to this study. I am sure that he has no interest 


\section{INTRODUCTION}

in my personal life, but he seems sure that "there is a story there," and I am inclined to agree with him.

Some people would read such a story to know just what kind of odd creature an entomologist usually is. Many reminiscent books have been written recently by scientific men, including naturalists. Two of these are quite charming and seem to have been widely read--those by David Fairchild and Frank M. Chapman, the one a botanist and the other a famous student of birds. No entomologist has ever told in book form of his life experiences, yet surely there is much romance and even drama in the lives of many of these men.

The trouble is that most of them have been men who have lived and worked in such a way that the world has not known of them. Until recently their pursuits were thought to be trivial. Insects were deemed small and insignificant-not worth the attention of a man in his right mind. Until quite recently many men were ashamed to let their friends know that they were studying insects and making collections.

Almost all of this is changed, as we shall see. But an entomologist is still a queer fellow in the eyes of many. And it must be confessed that many entomologists are queer fellows in the eyes of everyday conventional people. I remember that once many years ago a group of us were standing at luncheon time under the trees behind the building of the old Department of Agriculture at Washington when a tall, rather extraordinary-looking individual with pompadour hair and a strange two-pointed beard and not too careful dress (although perfectly neat) came out of an adjoining building.

"Who is that?" asked one of the bystanders.

"Oh, that's just one of Howard's entomological freaks," replied one of the group (he was a botanist, by the way).

Thus he spoke carelessly and laughingly of August Busck, 


\section{INTRODUCTION}

a Dane by birth and education, who has carried out most valuable investigations for us in foreign lands, and who is today a world authority on an important group of insects.

Very likely people might find the story of an entomologistthat is, an average, typical entomologist-interesting; but the particular entomologist who writes this, being perhaps more like the average man than is the average entomologist, has had the good luck to be thrown into positions in which he has been able to draw forcible attention to the insect problem, since he has in the course of the years taken part (usually a very small part) in many investigations that have been successful and have proved useful to all humanity. So why should not his life be interesting?

In the pages that will follow I hope to say many things that are far from entomology. I bring them in because I think them interesting, and because, after all, they help to prove my point, which is that an entomologist is very much like other people. The telling of these stories, relating as they do to an interesting period of sixty-odd years and to many interesting people and events, shows that he may be like other men. And then, too, many of these rather gossipy notes would be lost if I did not put them down here. Possibly this would not be a very great loss, but the reader will decide. 


\section{Contents}

INTRODUCTION

PAGE V

Chapter I

PAGE I

Parents, their birth in Central New York-Scientific ancestors of scientific men-Boyhood in Ithaca, New York-The Promethia Cocoons at Jamaica, Long Island-The Beginning of a collection of insects at Ithaca-The founding, by the boys, of the Ithaca Natural History Society-Early schooling-Death of my father-Entering Cornell University-First meeting with J. H. Comstock-More about boy life-The catching of the first Luna Moth-The non-resident lecturers in the early days at Cornell-Louis Agassiz-The first appearance of the European Cabbage Butterfly in Central New YorkC. V. Riley's lecture at Cornell-Graduation from the UniversityChoice of career-Post-graduate year preparatory to MedicineCornell in its early days, and more about life on Lake Cayuga-Frank Cushing at Cornell, Philadelphia, Washington-A walking trip to Eastern Pennsylvania-An offer to go to Washington as an assistant entomologist in the Department of Agriculture-S. H. Gage and the post-graduate year-Studies in the anatomy of insects in addition to the pre-medical studies-Riley's bad break in anatomy-Later years at Cornell as trustee-The dropping of the School of ForestryPresident Schurman-Ithaca of later years-Anecdote of Hiram Corson-Professor Prentiss and the Master's degree-Social life in 


\section{CONTENTS}

small towns, how it centers around the churches-Small town church life transferred to large cities.

\section{Chapter II}

PAGE 25

Work on the University farm and in the library-Departure for Washington-Visit in New York on the way-Journey from New York to Washington, and the old train of mules in BaltimoreJ. McK. Borden and his stepfather and mother, Colonel and Mrs. Carter-First impressions of the old Department of AgricultureFirst glimpse of C. V. Riley-Theodor Pergande and his attempts to write fine English-Disappointment at being used first as a clerkThe first manual of silk culture-The system in vogue at that time of credit to assistants-The resignation of C. V. Riley and the appointment of J. H. Comstock-The way the Comstocks and I lived and worked-First field trip-Congressional influence and appointments to public service-The consternation of office-holders at Cleveland's first election-Clerks' contributions to campaign funds-The great change with the coming of the Civil Service Law-Talks with General Black and John R. Proctor on state representation-Beginning of my study of the parasitic Hymenoptera-C. H. Fernald and his summer in Washington-The way he handled beggars-A story about Controller Trenholm-Garfield's election and Riley's reappointment-Doubt about staying in Washington-Sent on a field trip to Illinois-The sight of Garfield's assassination in the railway stationTrip to Savannah, Georgia, to study rice insects-Colonel Scriven and an anecdote of the fall of Savannah during the Civil War-A somewhat earlier trip to Louisiana, with anecdotes of a travelling Englishman-His account of the journey in his book-Investigation of sugar cane insects-Joe Jefferson's place in the Bayou Têche country-Somewhat later field trip to Huntsville, Alabama-Extraordinary work of parasites on the Army Worm-The 1884 stay in New Orleans-Victor Béro and his restaurant-Later work under Riley-The beginning of the journal "Insect Life"-The introduction of the Australian Ladybird into California-The disputed credit for this work-More about life in Washington-Music and a sudden cessation in the pleasure of listening to it-Riley's resignation and my appointment as Chief in $1894-$ Early studies in Medicine-The

$$
[\mathrm{x}]
$$




\section{CONTENTS}

old Colombian Medical College-A. F. A. King and his early ideas about malaria-The old faculty-A hospital anecdote-Later medical studies and later vivid interest in medical work.

\section{Chapter III}

OTHER occupations in Washington in the early days-The Scientific Societies and their beginnings-The old high bicycle and the Capitol Bicycle Club-The men who rode-Other bicycle clubs-S. S. McClure, Joseph Pennell-L. Warren Seely and one of his impromptu poems-Whist at the White House-Washington at that time-Congress-Blaine and Lamar-Logan, Vorhees and Edmunds-The proportion of college bred men in Congress-A debate on the Geological and Topographical Surveys-E. C. Manners and misquotationsAnother congressional incident-J. D. Cox-Early appropriations; a story about Congressman Hatch-Another about Senator Warner Miller-Congressman Wadsworth and his son, the Senator-The hearings before the Committee on Agriculture-The Boll Weevil and the committee-Burleson and Lamb-Congressmen and field laboratories-Congressional and political influence and appointmentsWilliam E. Chandler and the Cosmos Club-Uncle Joe Cannon's remark about the Club-Further about the Riley administrationStory of the Hop Plant-louse.

\section{Chapter IV}

PAGE 75

THE simple and inexpensive living of the young government workers in Washington in the early I880's-The small salaries of the young scientific men-Rare chances for outside work- "The Youths' Companion"- "The Century Dictionary"-Elliot Coues-New words in the Dictionary-My supposed knowledge of Sanskrit— "The Standard Dictionary" and "The New International Encyclopedia"-President Taylor of Vassar-First lecture without manuscript, a Vassar incident -The Lowell Institute-A St. Botolph Club experience with Wilton Lockwood-Married life-The Onteora Club-The wives of the scientific men in Washington.

\section{Chapter V}

EARLY interest in the natural control of pests-Beginning of study of parasites-Especial study of parasites of cosmopolitan insects-A

$$
\text { [xi ] }
$$




\section{CONTENTS}

catalogue of the recorded host-relations-The Australian Ladybird and its success in California-Later successes in Hawaii, Italy, Fiji and elsewhere-Work done in Washington-Coöperation with other countries-Search for European insect enemies of the Gipsy Moth and the Brown-tail Moth-Work in France, Italy, Austria, Hungary, Germany and Russia-Fritz Wagner-Josef Jablonowski-René Oburthür -André Vuillet-Mistral-J. Henri Fabre-Théophile GautierMarie Ruhl-Kiew-Waldemar Pospelow-Sebastopol and Simferopol -Sigismond Mokrzecki-Bachtisserai-Mayor Maximoff's estate at Balaklava-The Crimean War Museum-The Palace of the Khan of the Crimea at Bachtisserai-The Coming of the World War-Mokrzecki again-Later work on Gipsy Moth parasites in Europe-Socalled American Blight-Aphelinus mali, its introduction into Europe and throughout the world-The general subject-Albert KoebeleW. F. Fiske-Frederick Muir-Fiske again.

Chapter Vi

PAGE II6 MY VERY early observations on mosquitoes and the use of keroseneMalaria in Washington, open windows at night, and "Miasma"-The malarial "flats" at Ithaca-Later use of kerosene in the Catskills and publication in $1892-$ Bulletin on household insects in 1896 and on mosquitoes in 1898-First life history of Anopheles worked outConsultations with Reed, Carroll and Lazear-Results of their work -A book on mosquitoes in $190 \mathrm{I}-$ The beginning of the four-volume Carnegie monograph-The much later revision of the taxonomic portion in one volume by Dyar-How Dyar became interested in mosquitoes-Walter Reed's chagrin at statements in the rgor mosquito book-Later articles and lectures-The Panama Canal and interview with President Roosevelt-Gorgas and Le Prince at my office-An extraordinary earlier coincidence in Canada-An anecdote of General Gorgas-An anecdote of Dr. W. S. Thayer-Sir Ronald Ross and his I905 visit to America-The Yellow Fever Mosquito at the St. Louis World's Fair-Sir Rubert Boyce and Lord Mountmorris-Visit to New Orleans at the close of the epidemic of $1905-A$ Texas Yellow Fever story-The Roman Campagna and Malaria-Angelo Celli and a trip with him on the Campagna-Our "triumphal return" to Rome -First call on Grassi-His Germanisms-Grassi after the War-

$$
\text { [xii ] }
$$




\section{CONTENTS}

Visit with him to Fumacino-What he said about Ross-A Grassi anecdote-His ideas on Pellagra and Simulium and what he thought of bat roosts-Medical Entomology in the World War-The Housefly-Housefly discussion at two big functions at Washington.

\section{Chapter VII}

PAGE I44

EARLY silk culture in the United States-Experiments at Washington -Philip Walker-The McKinley Tariff Bill; effort to introduce a tariff on raw silk-Later experimental work under Secretary James Wilson-Miss Henrietta Aiken Kelly-Trip to Europe in Igo2 to study the industry and to buy reeling machinery-Silk culture on an old Italian estate-Abandonment of department work-Guy Wilkinson's experiments in California-The present experiment at Ensenada, California.

\section{Chapter VIII}

PAGE I55

RAPID growth of the Service at Washington-The San José Scale, the Mexican Cotton Boll Weevil and the discovery of the transfer of disease by insects-The broadening of the concept of.insect potentialities -Certain contrasts-Executive work interrupting personal investigations-The difficulties of the Field Assistant-Visits of the Chief to the field laboratories-Dudley Moulton and the Pear Thrips-The value of these visits to the workers-Their value before congressional committees-The Klamath Falls incident-Annual reports-Newspaper publicity-F. W. Clarke-How the newspapers improved in their treatment of science-The old days of the Huxley lectures-F. G. Novy and his Chicago address-Theodore Waters as press secretary of the American Association for the Advancement of Science-E. E. Slosson, Mr. Scripps, W. E. Ritter and Science Service-Austin H. Clark and the present press service of the American Association for the Advancement of Science.

\section{Chapter IX}

PAGE 169

UNINTENTIONAL interchange of injurious insects between countries through commerce-Early appreciation of this fact-Action of foreign governments-California's early quarantine law-Addresses in I895, urging necessity of national protection-Study of foreign pests liable to 


\section{CONTENTS}

be introduced-Mexican Orange Maggot-I 898 trip to Mexico-A suspected person who turned out to be very innocent and friendlyParodi at San José de Guaymas-No Orange Maggots in SonoraInternational episode at Hildalgo on a later trip-The incident of the Governor of Oaxaca-Dr. Liceaga and his inspection force-Patriotic incident at Córdoba-School histories-Yellow Fever at Laredo in I904-Yaqui prisoners on way to Yucatan-A. L. Herrera and his troubles during the Revolution-Alfonso Dampf-Late Coöperation with Mexico-Efforts to pass a Plant Quarantine Law in the United States-Efforts in I9I2 to strengthen European inspection servicesPassage of the United States law-Individual credit to C. L. MarlattInternational conference at Wageningen-The Plant Quarantine Service-Difficulties of the Service-The Rice Stem-borer as an example-Present conditions.

Chapter X

PAGE I84

International congresses-The Congress of Arts and Sciences at St. Louis in 1904-Simon Newcomb-Henri Poincaré-The International Congress of Zoölogy at Boston in 1907-Charles Sedgwick Minot and his dinner at the St. Botolph Club-The German professor at New York-Secretary James Wilson and Ralphael Blanchard at Washington-The International Congress of Agriculture at Vienna in I907-Franz Josef-The arguments of the bird lovers-Monsieur de Méline-The International Commission of Agriculture-Its meeting in Paris-The Marquis de Voguë-Monsieur de Tisserand-The Lamarck Centenary Fête in Paris in I908-Notable men presentThe Künckel d'Herculais incident-The incident of Dr. von GraffThe Darwin Centenary in England in 1907-Dr. Arthur ShipleyThe Two Hundred and Fiftieth Anniversary of the Royal Society in rgI2-Services at Westminster Abbey-The opening meeting-The incident of the German delegation-Banquet at Guild Hall-Speech of the Prime Minister-Speech of Lord Morley-Garden parties at Syon House and Windsor Castle-International Congress of Entomology at Oxford in 1912-E. B. Poulton-G. B. Grosvenor-The section on applied entomology-Anton Handlirsch-International Congress of Economic Entomologists and Phytopathologists at Wageningen, Holland in 1923-Attitude of the Germans-Discus- 


\section{CONTENTS}

sion of the title of the congress-The European use of the term phytopathology-The International Olive Fly Conference in Madrid, 1923-The earlier incident of the visit of the Principessa Brancaccio to Washington-Count Montornes-The International Congress of Agriculture at Paris in 1923-Secretary Wallace's comment on my speech-The Pan-Pacific Conservation Conference in Honolulu in I924-Internationalism and Sovietism-David Starr Jordan-Sir Joseph Carruthers-Accident on the way to Europe in 1925-The Glasgow Nursing Home-The Third International Congress of Entomology at Zürich in 1925-The International Congress of Zoölogy at Budapest in 1927-Dr. G. Horvath-The Fourth International Congress of Entomology at Ithaca in 1928-Some Pan-American Congresses at Washington-Dr. Zort and the Hygienic Congress.

\section{Chapter XI}

PAGE 2 I 8

THE American Association for the Advancement of Science-Early officers-Election as Permanent Secretary in 1898-Migratory meetings-The Toronto meeting of the British Association for the Advancement of Science in 1898 -Lord Kelvin, Lord Lister and Sir John Evans-Anecdote of Lord Lister-Sir John Evans and archæologyThe Red Lion Club-General Greely's initiation-The New Orleans meeting of the American Association for the Advancement of Science in 1905-Dr. Wiley's speech at the Boston Club Smoker-Investigation by the Postal Service-James J. McLaughlin's speech-The Denver meeting-John Hayes Hammond's dinner-Hammond's speech, years later, at an engineers' dinner in Washington-Franklin K. Lane's following speech-The Toronto meeting of $192 \mathrm{I}$-Professor William Bateson's lecture-An anecdote about Bateson-Charles W. Eliot's presidency at the Pittsburgh meeting during the War-An incident of this meeting-The Boston meeting in 1899-Josiah Quincy's dinner -W. G. Farlow-Farlow's address at New Orleans.

Chapter XII

PAGE 233

Concerning Presidents of the United States-Rutherford B. Hayes and Mrs. Hayes-A White House incident of his administrationPresident Garfield-His murder-Theodore Roosevelt-Roosevelt's address before the Biological Society of Washington while he was a 


\section{CONTENTS}

member of the U. S. Civil Service Commission-W. Hallett Phillips and his death-The dedication of Rudyard Kipling's poem, "The Red Gods"- The Panama Canal incident-The first conservation conference-William J. Bryan's comments and President Roosevelt's reply -The Pan-American Health Congress and the introduction of the delegates to President Roosevelt-Colonel Roosevelt and Sleeping Sickness-Ralphael Blanchard's conversation with Colonel Roosevelt in Paris-Colonel Roosevelt's final call on Kaiser Wilhelm-Gifford Pinchot's story-President Taft-Dinner conversation with George W. Wickersham-President Taft's address to the American Association for the Advancement of Science-Woodrow Wilson-Early meeting at the Hamilton Club in Brooklyn, and his speech on that occasion -Warren G. Harding-The first conference of Chiefs of BureausSpeech by Charles G. Dawes, first director of the budget-President Harding's support of a new Boll Weevil remedy-Dr. Sawyer-Incident of the birthday luncheon to Secretary Wallace-President Hoover-His address while Secretary of Commerce on the Delights of Fishing.

\section{Chapter XIII}

PAGE 253

The Cosmos Club of Washington-Comparison to other clubsEarly membership-Why I joined-Distinguished visitors-The incident of Lord Kelvin and Senator Jo Hawley-Conversation at the Club -The Wiley Scotch-Wiley and the New York dinner-Some billiard room small talk-Paul Bartlett-More about $\mathrm{H}$. W. Wiley-The chemical spelling match-The Club during the World War-Austin H. Clark-Reception during the War-German-American members of the Club-Dr. A. Caccini, his prognostications-L. P. DeBussy and his war stories-Major Plotz and his stories-Herbert QuickJohn H. Wigmore and his book on higher education in FranceMaurice Francis Egan-William Kent-A. B. MacCallum-R. V. V. Sewell and his offer to the Club-Frank P. Millet and his work-His ability as a linguist-An incident of his service at the U. S. Legation in Rome-The Millet Memorial meeting-Story of Millet and E. A. Schwarz-The Luncheon Club of Secretaries of national organizations -The discussion of Lincoln Memorials at this club and Millet's final words-Brander Matthews' story of the visit to the Millets by Lawrence

$$
\text { [xvi] }
$$




\section{CONTENTS}

Hutton and his wife-Dangerfield and the Spanish Mackerel-New England cooking-Arctic explorers.

ChApter XIV

PAGE 283

Alexander Graham Bell-The probable origin of his famous Wednesday evenings-What was done at those evenings and how it was done-Langley and his flying machine-Bell's interest in flyingHis tetrahedral kite-McCurdy, Orville Wright, Santos Dumont and Glenn Curtiss-C. M. Manly-Incident of the Contessa MontessoriDr. Bell's three cigars a day-Physicians and tobacco-The origin of the Walter Reed Memorial-The wide reputation of the Wednesday evenings-Echoes from France and Hawaii-Spencer Miller and his remarks-The World War and the discussion after the United States entered it-Duca Litta's letter-Remarks of Meyer, the agricultural explorer-Dr. Bell's character-James Harvey Robinson on such men - Voltaire on the inventor-Personal acquaintance with five generations of the family-Herbert Putnam and the Round Table ClubThe reunion after the World War-Remarks of Roland Cotton Smith and M. Jusserand-A meeting with Dr. Bell's great-granddaughter in Japan in I93I.

\section{Chapter XV}

PAGE 300

THE Clover-seed Midge-Theodor Pergande's story-SpiritualismSir Alfred Russell Wallace-Bernard E. Fernow and the School of Forestry at Cornell-Poulton and Fernow climb a mountain-The Capri Fig Story-The two Wileys and the Legion of Honor-The Commissioners and the Secretaries of Agriculture-General Le DucSir Basil Zaharoff-An episode concerning Nicolas CholodkowskyCredit to Dr. Holland for a story in "The Insect Menace"-End of official career-Colonel Charles E. Davis-Recent book-The Celebration of the Centenary of the French Entomological Society-The Fifth International Congress of Entomology in Paris. 


\section{Chapter I}

I

F THERE be such a thing as an average boy, I believe I was one. My father, Ossian Gregory Howard, was born in Delhi, New York, and my mother, Lucy Dunham Thurber, was born in the same little town two years later. My father studied law with a law firm at Ithaca, and after he was admitted to the bar he married and started for the west with his young wife to begin life in a new and growing country. They settled at Rockford, Illinois, fifty miles or more west of Chicago, and I was born near the close of their first year there. Then the law firm with which he had studied offered him a partnership, and the young father, mother and baby went back east to Ithaca, and there I grew up and went to school.

My friend, C. B. Davenport, the head of the Eugenics Laboratory at Cold Spring Harbor, is very keen on the subject of the genealogy of men of science and has collected the data concerning all of the members of the National Academy of Science, as well as of many other scientific men, in the effort to find out any evidences of heredity in scientific tastes. Such evidence in my own case is very slight. My paternal ancestors were for the most part physicians and preachers, with an occasional farmer, and the same holds for my maternal ancestors. However, my 


\section{FIGHTING THE INSECTS}

paternal grandfather, Dr. Calvin Howard of Delhi, was an amateur astronomer and founded a local Natural History Society in the $1840^{\circ}$ 's. Moreover, my maternal great-grandmother was Lois Pickering, coming from the famous Pickering family of Massachusetts, in which there has been, here and there, a man of science, notably the late Professor E. C. Pickering of Harvard, the noted astronomer and member of many foreign scientific academies, and Dr. Charles Pickering of Philadelphia (of the class of 1826 at Harvard), who was prominent in the early days of the Philadelphia Academy of Natural Sciences. He was greatly interested in the geographical distribution of plants and animals, and travelled much. ${ }^{1}$

Other instances of this sort are lacking as far as I know. Even, however, had there been no ancestry of scientific accomplishment, it is the most natural thing in the world that a boy brought up in the Central New York environment should be attracted to nature, and many of my boyhood friends were so attracted. But that I happened to be the only one who followed one aspect of nature study as a pursuit was more or less accidental.

Ithaca is at the head of a beautiful lake, and is in a valley surrounded by hills, except on the lake side, and these hills in my time were rather well-wooded. The boys rowed and sailed on the lake, camped in the woods in huts that they made of poles and the dense foliage of the hemlock, and fished in all the tributary streams. Some of them collected birds' eggs and studied

${ }^{1}$ Lacking near ancestors of scientific attainment, I have been a little more fortunate with men who have come into the public eye in other ways. Jacob $\mathrm{M}$. Howard, United States Senator for Michigan, and one of the founders of the Republican Party, was my grandfather's first cousin. General O. O. Howard, of Civil War fame, belonged to the same line. The former President and Chief Justice, William Howard Taft, was rather proud of his middle name, which is that of his grandmother, who was a cousin of my grandfather. The present Secretary of State, Henry L. Stimson, by the way, is my mother's grandnephew. 


\section{THE STORY OF AN ENTOMOLOGIST}

birds; one or two others became interested in land shells; but that was as far as any specific interest in natural history went until, when I was seven or eight years old, I visited an aunt, Mrs. Candace Wheeler, who lived near Jamaica, Long Island. There one winter I met the children of some neighbors named Stewart, and two of the boys were collecting cocoons. I became interested at once when they told me that beautiful moths would issue from these cocoons in the late spring. I took some of the cocoons home with me to Ithaca, and was entranced when the moths (Crecopia and Promethia) burst out the following May. From that time on I collected moths and butterflies. Rather strangely, my mother and father encouraged me. They bought me a little book by Mrs. Mary Treat called "The Butterfly Hunters," and when I was ten years old my father gave me the wonderful book by T. W. Harris-"Insects Injurious to Vegetation."

Boys are imitative, and occupations of that sort are attractive, so a dozen of us organized The Ithaca Natural History Society. We had weekly meetings and read papers and talked over many puzzling things. In the meantime Cornell University had been started, and soon there was established a University Natural History Society. But the meetings of that society were not half so interesting as were those of our little group. We made no attempt to build up a society collection, but nearly every one of the boys had his own private collection, and the collector's spirit was almost as intense as that shown by many older people in many different directions. This little society lasted till some of us were ready to enter college, and even afterwards.

My father was not a college man. In the old-fashioned way he studied law in a law office, and was admitted to the Bar on examination. He thought that a college education was not necessary, that it was in a way a waste of time, and it had been his intention to place me in his office as a student at the age of six- 


\section{FIGHTING THE INSECTS}

teen. In the meantime I had done fairly well at school (The Ithaca Academy). About $187 \mathrm{I}$ I got into some difficulty with the Principal, was feruled, and indignantly left school. My father took my side enthusiastically and put me into an excellent private school of which Mr. William Kinne was Headmaster. It was really a Latin school, but taught mathematics and other things, and was an accepted preparatory school for the universities.

Then suddenly, in the night, in March, 1873, my father died, at the age of forty. He left my mother with three boys to care for and to educate. I was fifteen, my brother George ten, and my brother Frank six. She took up the burden bravely. Her financial means were comparatively small, although she had some valuable real estate, and a big house that my father had built two years before.

Both father and mother had associated much with the young professors of the University and their families, and my mother realized that I should enter the University immediately. So on my sixteenth birthday I passed the entrance examination and registered as a freshman in September, 1873 .

I entered in the course of Civil Engineering, although I wanted to study Natural History. My mother's professorial friends, however, assured her that there was no future in Natural History, except possibly an underpaid professorship in some small college. Civil Engineering was then very much in the public eye. Great railroads were being built, American engineers were being sent to South America and all over the world to build railroads, and the engineering courses were filled with students.

It proved to be an interesting experience, but when I got into Differential Calculus it was too much for me, and I failed in my examinations. Then, without telling my mother, I took the studies I liked best. I was J. H. Comstock's first laboratory student, and I spent many hours in his laboratory. I studied 


\section{THE STORY OF AN ENTOMOLOGIST}

botany, geology, and chemistry, and also went in for history and - perhaps especially-the French, Italian and German languages.

I had first met Comstock before entering college. I was out collecting and for the first time had found the very beautiful Huntera butterfly, flying rather abundantly in a field of blossoming buckwheat. A strange young man walked up and said to me, "C-c-catching insects?" I replied affirmatively, and he said, "M-m-my name is Comstock, and I t-t-teach entomology in the college. C-c-c-come and see me." This was the beginning of a lifelong friendship. I went to see him, gave him insects for his newly started collection, and read his books, for the first time making the acquaintance of Lyonnet, Réaumur, Westwood, Kirby and Spence, Rennie, John Curtiss, Fitch, Walsh, and a lot of others; for Comstock was already beginning a library in entomology which has since become one of the most important in Americá.

But we have gone ahead too rapidly. It is true that this is the story of an entomologist, but it is also the story of an average boy. From what has been said before, it is not to be supposed that the boy collector of insects has anything more than the same collector's spirit that always shows itself with boys, whether they gather postage stamps or old coins or birds' eggs or match-boxes, or glittering things as a jackdaw does. My real interests were in baseball, rowing, sailing on the lake, camping in the woods, and boy games of all kinds. I had to practise on the piano, and what a struggle it was when the other boys were playing baseball almost under the window!

In the collecting of insects there was a rivalry among the boys. I remember how jealous I was when one of them caught the first Red Admiral. When we saw Sonrel's wonderful woodcut of the Luna Moth in Harris we were all agog to see who should catch the first one. 


\section{FIGHTING THE INSECTS}

One day when we were in swimming one of the boys, Henry White, the son of the Presbyterian clergyman, dressed first, took his elaborate butterfly net, and started off into the woods. My brother George, who had no butterfly net, and whose collecting apparatus consisted of an old straw hat, followed him. As I was leisurely dressing, I heard yells of delight in the woods beyond and voices crying excitedly, "A Luna! A Luna!" "Thunder!" I said to myself. "Henry has caught the first one." Without waiting to draw on my shoes, I started after them, and when I got there, beheld the kid brother on his hands and knees, with the Luna under his straw hat, while Henry with his expensive butterfly net stood by trembling with jealous rage!

In those early days the University wisely drew in a number of prominent non-resident lecturers. Among them was the elder Agassiz, and as a boy I heard several of his lectures. I was not so much interested in his subject, which mainly concerned sea forms of life, but I was greatly interested in the man himself and in his rapid and picturesque way of presenting his subject. Of course this was before the days of lantern slides, and while the lectures were profusely illustrated, it was all done with crayon on a great blackboard. And for the first time I saw a man draw with a bit of chalk in each hand, using both simultaneously. It was arresting; it was beautiful! And how much easier it was to draw a bi-symmetrical figure with two hands than with one! Years later I saw the late E. S. Morse (a student of Agassiz) do the same thing and even better. And still later C. V. Riley, but hardly with the same success, although he sketched normally in an exquisite way.

Before each lecture Agassiz allowed the students to ask questions for a few minutes. I remember with great joy that a fellow named Charley Raymond stood up very impressively one night and said, "Professor, is there such a place as Hell?" The rotund 


\section{THE STORY OF AN ENTOMOLOGIST}

and genial Swiss smiled, shrugged his shoulders and answered: "I wish I knew!"

I am sure that in those boyhood days I did not appreciate the importance of studying insects from the life history point of view, and not at all from the economic. In fact, although I subsequently gave my collection to Cornell University, I believe that I made only one observation of any especial interest. It happened in this way: I spent the summer of 1870 or $187 \mathrm{II}$ (I forget which) at my grandfather's in Delhi, Delaware County, New York, and while there collected butterflies, incidentally interesting one or two of the local boys. There I found in some number a white butterfly which I identified in Harris as Pontia oleracea, and Harris stated that its larva fed on cabbage and other cruciferous plants. I took a dozen of these butterflies back with me to Ithaca, where the species had not been found, and traded them with some of the other boys. The next summer I wanted some more for trading purposes, so I wrote to Charley Frost, a Delhi boy, and asked him to send me some, since I knew that they had been very common down there the summer before. To my great surprise, he sent me back an entirely different species. It was white like the other, but it had some black spots on the wings.

Now, as it happens, this incident fixes the date at which the European Cabbage Butterfly (Pieris rapa) reached that part of New York. It had been accidentally imported at Montreal, Canada, a few years before, and its rapid spreading over the United States was a matter of much interest to naturalists and to cabbage-growers.

This was all written up later by S. H. Scudder in an important paper, and he was able to fix the date of the entry of the species into the lower Catskill regions by this boyhood observation by Charley Frost and myself. So that even small boys sometimes hit upon a good thing. 


\section{FIGHTING THE INSECTS}

It seems rather astonishing to me now that, although Cornell was founded upon somewhat utilitarian lines, and included a College of Agriculture, the courses in entomology had very little reference to possible practical applications. But perhaps this was not to be wondered at, for, aside from the not very well known writings of Harris, Fitch and Walsh, almost nothing was being done in this direction. In fact, the science of applied entomology was only just beginning.

There was a young man down in Missouri named C. V. Riley, who had been publishing a few annual reports on noxious insects and had created quite a sensation, partly by the admirable way in which he presented his subject, and partly by the extraordinarily clever illustrations. In 187 I or 1872 Professor Comstock managed to have Riley invited to come to Ithaca to deliver two or three non-resident lectures. We boys of the Natural History Society attended in a body. We were much disappointed in the lectures. We cared nothing about agriculture, and were interested only in the strange things about insects. Some of the farmers who came were disappointed because the lectures were not practical enough to suit them. And some of the professors who came out of curiosity were outraged because this young man ventured to criticize the recently published classification by Packard, a representative of the New England School, and a student of Louis Agassiz, then in the height of his fame. The one thing that pleased all of us was Riley's extraordinary ability as a blackboard artist.

Looking back at the college days, between September, 1873 and June, I877, when I took my Baccalaureate degree, I see very well that entomology was not my principal interest. I played baseball on the class team, and football as well, rowed on the crew of the Tom Hughes Boat Club, and entered into many of 


\section{THE STORY OF AN ENTOMOLOGIST}

the undergraduate activities. As pointed out in an earlier paragraph, I took the studies I liked, and indeed I have found since that the studies that I chose of my own volition have been of much use to me-I like to think much more so than any of the prescribed courses would have been. But when it came to graduation, it was a somewhat different story. The Faculty Committee insisted that I should round matters up, and I had to do some intense cramming in physics before I was given my B.S. When it came to a thesis, howvever, I went back to my first love and prepared a rather elaborate treatise on the "Respiratory System of the Larva of Corydalis cornuta," an aquatic insect largely used by bass fishermen as bait, and often known by the curious name of Hellgrammite.

And now came the question of career. I wanted to be a teacher of natural history, but the men in the Faculty who were friends of my mother told her that it would be foolish to rely on anything of that sort, and advised her to place me in line for a medical career. As this probably would have been my second choice, I entered the University for a post-graduate course in studies preparatory to medicine, taking up histology, chemistry and advanced botany (including what was then known of mycology, and what was then beginning to be known as bacteriology). And I also took up comparative anatomy. I entered upon all these studies with enthusiasm and learned a lot. Dear old Professor S. H. Gage and I, working together in Burt G. Wilder's laboratory, learned a great deal and enjoyed every minute of our association. Gage had graduated with me and was now instructor. We had many funny experiences, for example: Gage had seen in a microscope journal that a new reagent-osmic acid-had been found to be an excellent stainer of nerve tissues, and he promptly ordered an ounce. When the bill came in it proved to be something like one hundred dollars, 


\section{FIGHTING THE INSECTS}

which wrecked the laboratory appropriation for a year. We dissected dogs and cats, and later still-born babies which were sent to us from New York, and we had many a dirty mess in our early efforts to inject in the veins and arteries colored plasterof-paris in liquid form.

The Cornell University of my undergraduate days seemed wonderful to us small-town people, and yet in the light of its subsequent growth, and in comparison with the many great universities which have sprung up since in the United States, it now seems to have been rather a primitive affair. Still there were many things connected with it that made it stand out prominently and brought upon it a great deal of criticism and abuse. In the first place it was non-sectarian, and that was almost unheard of in American collegiate institutions. And then it introduced many innovations in its line of studies. Ezra Cornell, its founder, was a self-made, self-educated man, who had big but rather indefinite ideas. His oft-quoted statement, "I would found an institution where any man can find instruction in any study," was high-sounding, rather grandiloquent, and, in a way, rather naïvely stupid, but it was very impressive to lots of us. In the early Faculty there were men who had been chosen for such things as a knowledge of Sanskrit, for instance, although I do not remember that anyone ever took any instruction in Sanskrit. However, all this has been written up again and again, and the controversies of that time are now matters of history. In spite of all its crudities, there was a great deal that was sound and fine about the University in those days, and the fact that Andrew D. White was its first President, and the other fact that no less a person than Professor Goldwin Smith, who had recently left the Regius Professorship of History at Oxford, and had come over to Canada, came down to Ithaca and gave annual [10] 


\section{THE STORY OF AN ENTOMOLOGIST}

courses of lectures, and eventually left a large share of his fortune to the institution, speak more for the ideals and the atmosphere than any amount of argument.

I have indicated my interest in many other things besides entomology. My summer vacations were spent largely in camping on the shores of Lake Cayuga. In the summer of I876 I saw the intercollegiate boat races on Lake Saratoga, where, incidentally, Cornell won the 'Varsity race, the Freshman race and the single sculls against Yale, Harvard, Columbia and eight or ten other universities. And later in the same summer I went to the Centennial Exposition at Philadelphia-an extremely broadening and interesting experience for a boy who had never left Central New York before, except for occasional visits to New York City.

There is an interesting little story connected with this Exposition. There was a boy named Frank Cushing who came to Cornell in 1875 and joined our Natural History Society. He was a keen observer, and was especially interested in archæology, notably the archrology of the American Indian. He had an extraordinary aptitude for finding Indian relics. For example, one day he and I were looking out of the upper windows of one of the university buildings across the valley to the western hills, two miles or more away, and he pointed out a certain spot on the hillside and said to me: "By George! I'm sure there must have been an Indian camp at that spot." Next day he went over there alone and returned at night with arrowheads and other Indian relics that proved the accuracy of his long-range judgment.

In the winter of 1875 to 1876 the Smithsonian Institution sent out letters to persons interested in Indian relics, and asked them to contribute to the exhibit that would be made by the Smithsonian at the Exposition. Frank Cushing sent in a wonderful lot 


\section{FIGHTING THE INSECTS}

of things, and in the spring of 1876 he was asked to go to Philadelphia to help in the installation of the exhibit. When he arrived everything was in confusion, and even the floors of some of the buildings had not been laid. In walking through Machinery Hall the toe of his boot struck a bit of stone projecting from the earthen floor. No one knows how many boots had hit this obstruction, but Cushing dug around it and exhumed the old object, which proved to be a very remarkable Indian pestle. In fact, he proved so interesting and so apt and so well informed that the Smithsonian took him away from his college course, and he went to Washington with the exhibit at the end of the Exposition. That was Frank Cushing's chance, and, as we all know, he developed into one of the most remarkable students of the American Indian that the United States has ever produced. $\mathrm{He}$ got to know the Zuñis, that extraordinary tribe in the Southwest, and in fact was adopted into the tribe.

I think that I should mention one more little expedition. In the late summer of 1877 a half dozen of us started south on a walking trip. We had intended to explore the coal-mining region of eastern Pennsylvania. When we reached Towanda we were already footsore, and, finding there the eastern branch of the Susquehanna river, we bought a flat-bottomed boat for four dollars, cut ourselves out some paddles from stolen fence-boards, loaded our packs and supplies in the boat, and cruised for a large part of the rest of our journey. We cooked our own meals on shore at camp-fires, and spent the nights in chance haymows. We overturned at least once, and had many more or less commonplace adventures which were very exciting to our inexperience. There is no doubt that we looked like tramps. We indulged in a dinner at a little hotel at Pittston and were served by a pretty country girl. One of us passed some chaffing remark to her, and she flushed and ran into the adjoining room, and we 


\section{THE STORY OF AN ENTOMOLOGIST}

heard her say to the landlady that she would not have anything more to do with such a job. And the landlady said to her, "My dear girl, when you took this place you must have known that you would have to wait upon all sorts of impossible people." That was rather a shock to half a dozen boys who had just graduated from college. But another shock came later. I left the party at Wilkes-Barre and went into a barber shop to get cleaned up before taking the train for home. As I entered the shop, the German barber greeted me enthusiastically and said, "Vell, old man, how you vas?" I told him that I was very well and asked him where he thought he had known me. "Oh, go 'vay, you tended bar next my shop at de Exposition las' year."

To go back to the post-graduate year. I don't think I ever enjoyed a year more than that one. There were eight or ten advanced students in Gage's laboratory, and we worked with unequalled enthusiasm, inspired largely by Gage, and I got many ideas that have proved of great value to me, and so, I am sure, did the other men. Most of them went into medicine.

At the end of the college year, in June, 1878, Professor C. V. Riley, who had just been brought from Missouri to take the post of Entomologist to the U. S. Department of Agriculture, which had long been filled by the Englishman, Townend Glover, was about to begin an investigation of the cotton caterpillar in the south. He knew Professor Comstock from having given the non-resident lectures at Cornell referred to in an earlier paragraph, and wrote to him offering him a job as Field Agent in the southern cotton fields during the long summer vacation. Comstock accepted, went South and spent most of the summer in Selma, Alabama, sticking to his work indomitably in spite of the fact that it was a yellow fever summer and conditions throughout the southern states were very alarming. 


\section{FIGHTING THE INSECTS}

On his way through Washington in June, Professor Riley asked him whether he had at Cornell an advanced student of good appearance, fairly good manners and ability, who could come to Washington as his assistant. Comstock was good enough to recommend me, and in July I received a letter from Riley asking me if I would come to Washington in the autumn at a salary of one hundred dollars a month. Of course I wanted to go, but I talked it over with my mother, my father's old law partner, Judge Beers, and a number of the professors in the University. They all said that I would never be rich and that they doubted whether I would ever be able to marry and live comfortably. The opinion that weighed most with me was voiced by Professor Burt G. Wilder, who said to me that naturalists as a rule did not care at all about money, and not especially about comfort; that naturalists were born and not made, and that he thought on the whole that I was a born naturalist. And so I accepted.

In early November, I878, I started for Washington. My friends gave me a send-off, and Professor Gage, going to the train, shook hands in parting and said, "Now, Brother Howard, you and I are going to devote our lives to science. We are not going to let any confounded girls come between us and our work." I quite endorsed this sentiment, and was greatly disappointed when, a year later, I received Gage's wedding cards. The next time I saw him I taxed him as a backslider, and he said, "Well, you see, Brother Howard, I discovered what a great thing it is to find someone who believes in you thoroughly and thinks that you are quite the greatest person in the world." As a matter of fact, Gage's married life was very happy. His wife was a true helpmate, gave him a brilliant son, and herself did some biological work of high character. Her papers were signed Susanna Phelps Gage. The son, Phelps Gage, who has grown into a 


\section{THE STORY OF AN ENTOMOLOGIST}

physicist of great ability, was an eccentric youth. In the basement of the so-called McGraw Building Dr. Wilder used to keep the cats and dogs and other animals that were used in his laboratory, and the place was overrun with fleas. The janitor used to roll sheets of sticky fly-paper about his ankles in cylindrical form, with the sticky surface outside. This, of course, inflicted great mortality on the fleas because of their pernicious habit of jumping from the floor to one's ankles. Four-year old Phelps was much intrigued by this process, and insisted on having his own ankles similarly wrapped. But he carelessly brought his legs together, and then there was a howl for his father to come and "unstick" him. Phelps had an ingenious way of simplifying the English language. For example, when asked where his father was, he replied, "He's gone to the Uni to study the mike." Meaning, of course, that he had gone to the University to study the microscope.

Just one more story about Phelps. Once, at a Rochester meeting of the American Association for the Advancement of Science, his father was Chairman of the Section of Zoology, and the delivery of his address as Chairman was listened to by a large audience. The subject was an important one relating to physiology. Phelps and his mother were present on seats near the front. Phelps, who must have been about six or seven years of age, was dressed in a bright blue suit. He was obviously much concerned about the effect of his father's speech, because after nearly an hour he climbed up in his seat and said in his clear, childish voice, "Father, you've talked too long already."

November third, I878, I cast my first vote. It was mid-term elections, and I voted for Alonzo B. Cornell, the son of old Ezra, for Governor. I had known Governor Cornell as a boy knows an older man, and his son Charles had been a boyhood friend 


\section{FIGHTING THE INSECTS}

of mine. So also was Fred White, the son of the President of the University. I should also state that another old boyhood friend was Frank Finch, the oldest son of Francis M. Finch, later Judge of the Supreme Court of New York, who during his early days was a poet of much ability. When he was a student at Yale he wrote a number of Yale songs, and at the close of the Civil War he published that wonderful and beautiful poem, "The Blue and the Gray," which has been recited at the Decoration Day exercises all over the north on every thirtieth of May since that time. It may interest many to know that Judge Finch was at that time a Democrat in politics. In those days of high political excitement he was even called a "Copperhead." Therefore, the following will, I am sure, be interesting. In the spring of 1866 I was walking up the hill one day towards our house when I saw Judge Finch leaning against the fence and sobbing. I was shocked and curious, and said, "Why, Mr. Finch, what is the matter?" He turned and choked out between sobs, "Leal, the news has just come that President Lincoln has been murdered."

Possibly I have said more than enough about the boyhood days in Ithaca and the student life at Cornell. But it is hard to leave that period. I suppose that everyone feels the same way about that sort of thing. At the age of nearly seventy-five, writing, as it happens, at the present moment in Paris, and having lived for much more than two-thirds of my life away from Ithaca, my mind goes back constantly to college days. I often think, for example, of stealing hickory nuts on the margin of Ezra Cornell's big place, and I can visualize old Ezra himself, with his long black coat and his stove-pipe hat and his big stick, coming out of his house in a very bad temper to stop the pilfering. The old gentleman (he wasn't so very old then, but he seemed so to me) always wore a stove-pipe hat, and I smiled to myself 


\section{THE STORY OF AN ENTOMOLOGIST}

when I heard that some famous artist had made a statue of him that has been placed somewhere on the campus. It did not seem to me that a stove-pipe hat belonged on an artistic statue, but it was impossible for me to think of the old gentleman without that headgear.

Of the pre-college days I think mainly of outdoor games and of the boys with whom I played. Of the college days I think also mainly of baseball, football and rowing, and of the boys I knew in my own class and in the classes next to it. At that time I was very greatly interested in the Ithaca Natural History Society, which I had helped to found, and in my own collection of insects, which gradually grew to contain a very fair local representation of the butterflies, moths and grasshoppers. After I entered college I found that Professor Comstock had brought together a good collection of European books, many of them old, and I read them hungrily. I was fascinated by Kirby and Spence, by Rennie's "Insect Architecture," by Réamur's great work, and especially by the wonderfully illustrated book by the French writer Lyonnet on the anatomy of the Cossus. This insect is a great wood-boring caterpillar that lives in the trunks of trees in France. I was so fascinated by Lyonnet's engravings that I began at once to study the anatomy of the large American caterpillars, and as a result, as already stated, my graduation thesis was entitled, "The Respiratory System of the Larva of Corydalis cornuta."

Apropos of this anatomical work, I am tempted to tell a story. Professor Riley, good entomologist that he was in many ways, had apparently never paid much attention to insect anatomy, and when in one of his latest Missouri reports he published an illustration of one of the almost transparent larvx of the Grapevine Phylloxera, the tracheal system was plainly indicated. In his text he referred to it as the nervous system. During the 


\section{FIGHTING THE INSECTS}

winter of 1878-79, while I was working with Riley in Washington, Professor E. L. Mark of Harvard, then recently returned from long studies in Germany, published a note in The Canadian Entomologist, calling attention to this rather absurd error. When he read this article Riley called me into his office and with the Missouri report open at the figure in question asked me what I thought of it. I said, "It is a very fine drawing, and I wonder at the accuracy with which the tracheal system is drawn." $\mathrm{He}$ thanked me and dismissed me.

It will be noticed that all along I had studied insects simply because I liked to do so. It was not my prime interest, but it was one of my prime interests. I had no idea of becoming a specialist, and of course the future was all in the air. But everything that I learned about them and, in fact, everything that I learned about other things, was well worth while, and it has all proved of much use to me at one time or another.

As a matter of fact, I never really worked until the postgraduate year. It is true that I had very good marks on the whole, but that is because I chose only the subjects that were most interesting to me. But when the post-graduate year came and I spent all my time on Natural History, Comparative Anatomy, Histology and the subjects leading up to Medicine, I regretted the hours that I could not spend in one laboratory or another. My eyes were opened to the immense importance of many fields. I must say, however, that the practical importance of entomology did not appeal to me, and I studied insects simply as fascinating forms of life. Of course I was not alone in this, and no one at that time had the faintest idea of what insects were then doing to the human race, and still less of what they were likely to do in the future. In fact, when in the early summer of 1878 Professor Riley began to correspond with me about going to Washington I looked upon this suggested post as simply an 


\section{THE STORY OF AN ENTOMOLOGIST}

agreeable way of earning a living until I could go into something bigger and broader.

I think this will be a good place to tell what more I have to say about Ithaca and Cornell. In I884, after a short residence in New York, my mother had married a second time. My stepfather, George William Harris, a Nova Scotian by birth, held the position of librarian in Cornell University for many years, succeeding the well-known Willard Fiske, the Dante and Icelandic scholar. So it was that I went back to Cornell annually until the time of my mother's death in 1893 .

After that, for a period of years, I did not return. But in 1900 I was elected to a five-year term as Alumni Trustee, and this brought me back twice a year, in the autumn and in the spring, to the Trustee meetings. In the meantime Andrew D. White had resigned as president to become Ambassador to Germany. Charles Kendall Adams of Ann Arbor was president for a few years, when he resigned and was succeeded by Jacob G. Schurman, who held the office for many years, including those of my term as trustee. Schurman, also a Nova Scotian by birth, had studied philosophy in Germany and had occupied the professorship of philosophy at Cornell. He was a young, charming, high-minded, almost spiritual personality. He married a delightful and wealthy lady from New York and was very successful in his management of the affairs of the University.

I went back to Ithaca to the first meeting of the Board of Trustees in a very modest frame of mind, but impressed with the responsibilities of my new office. I soon found that the Board and the President were virtually controlled by the executive committee, composed of local residents, and I thought I saw that their horizon was very limited. The out-of-town members of the Board, coming to Ithaca only twice a year, had apparently little 


\section{FIGHTING THE INSECTS}

weight. The President with his broader outlook carried tact to the extreme, it seemed to me. On thinking it over, however, I realized that he had to live with these people, while we outsiders did not. And, after all, things went well. But there were two emergencies that aroused my rather strenuous opposition to the local people. One was the typhoid epidemic in Ithaca and in the University, and the other the abolition of the School of Forestry. These are old stories, and it is unnecessary to retell them. Typhoid dangers have largely passed away, and the School of Forestry has been reëstablished. The saddest thing about the latter, however, was the dismissal of my old friend, B. E. Fernow. I shall say something about this fine man and the Forestry episode in later pages.

During his term of office as President of the University, Dr. Schurman was twice given long leaves of absence, the first to go as a commissioner to the Philippine Islands and the other to serve as Minister to Greece. When he finally gave up his position at Cornell, he was made Minister to China, and later, after we had resumed diplomatic relations with Germany, ambassador to that country. He filled all of these posts very acceptably.

After the expiration of my trusteeship in 1905, there followed another long absence from Central New York. I went back to the University at the time of the impressive semi-centennial of its founding in 1918 and again to the semi-centennial of the graduation of my class in 1927. And once more I returned in 1928 as President of the Fourth International Congress of Entomology that was held at Ithaca, for the first time in the United States, previous meetings having been held in Brussels, Oxford and Zürich.

I think of Ithaca as the wooded village of my boyhood, and, after all, it has not changed so greatly. It has more than trebled in size, but that is nothing in our country of rapidly growing cities. It is still densely shaded, its gardens are beautiful, its 


\section{THE STORY OF AN ENTOMOLOGIST}

people are still of the fine Central New York type, with an added culture brought there by the University. But I think they are rather too aware of the latter. Still, judging superficially from my occasional visits, the atmosphere of the town has changed somewhat. It is no longer quite so much of a country village, but has become metropolitanized to a certain extent.

In Ithaca, they tell a story about Professor Hiram Corson that is worth repeating. This man who was very much of a scholar, and who had been with the University almost since its beginning, was slender and solemn, and had a sepulchral voice. When he allowed himself small conversation he did it in a sepulchral way. The Professor had a keen sense of humor, but no trace of it ever appeared in his face. When, after prolonged efforts, the trolley line was first established, the service for a while was not satisfactory. One day he joined a young lady standing on a corner awaiting a car. She said, "Good morning, Professor Corson. I am greatly annoyed: I have been waiting for a car for twenty minutes." "Madame," replied Professor Corson in a deep voice (he was an extraordinary elocutionist), "I have been waiting for this car for twenty years."

Here is another anecdote about Professor Corson that has not been told in print. My parents were giving an evening reception, and I, a small boy, was allowed to stay up and stand around in corners. Coffee was always served at these evening affairs, and I happened to be standing near Corson and Professor Prentiss, the botanist, also a tall, solemn and rather lugubrious person, and I overheard this conversation between the two. "Corson," said Prentiss, "what would life be without coffee?" Corson thought a moment and said, as though plunged into infinite sadness, "Prentiss, after all, what is life even with coffee?" That conversation I have never forgotten. In fact, it rather saddened my life for several days.

But later in student days and afterwards I found that both 


\section{FIGHTING THE INSECTS}

Corson and Prentiss were very good fellows. After I had been in Washington for a few years, it occurred to me that I would try for a Master's Degree, and I wrote to Cornell about it. They replied that they would take my year's post-graduate study at Ithaca into account as well as the papers I had published, but that they would require a thesis and an examination in botany. I submitted as a thesis a paper that I had recently prepared and that was ready for publication. I remember that its title was "The Morphology of the Chalcididx." I wrote to Professor Prentiss and asked him about the botany examination. He replied that I should prepare an herbarium of one hundred species of plants to which I should attach the names, and that I should then come to Ithaca and undergo an oral examination. I enjoyed the preparation of the herbarium and took it with me to Ithaca. This was the oral examination:

Prentiss: "Good day, Mr. Howard. I have looked at your herbarium and find the specimens neatly mounted and correctly named. You enjoy your work in Washington, I hope? Professor Comstock has told me nice things about it. How is your mother now? And where is she?"

Howard: "She is very well, Professor, and happens just now to be in London."

Prentiss: "Will you please give her my cordial greetings when you write? That is all. The examination is finished."

And I got my Master's Degree at Commencement in 1886 . Since that time I have always thought of Professor Prentiss in a most friendly way. He was a fine man and a very kindly one. He was an admirable botanist and would probably have made a great name, had he not died at a comparatively early age.

Many of my early recollections of Ithaca were connected with the church. My parents belonged to the First Presbyterian Church, 


\section{THE STORY OF AN ENTOMOLOGIST}

and I went to Sunday School and usually to two services on Sunday. The Presbyterian Church in those days was rather puritanical and was based on the Scotch type of Presbyterianismforeordination, infant damnation and all that. I am rather glad to remember that my mind rebelled at many of the tenets and that when I had grown almost to manhood I welcomed what I heard of the lectures of Robert G. Ingersoll.

In those days the social life of the small towns and villages, not only in Central New York and in New England, but elsewhere in the United States, centered around the churches. There was nothing else around which it could center. It was a distinct survival of Puritanism, and it still holds. Thousands upon thousands of men in public life have come from such an environment, and, on the whole, it is a good and healthy one. There was, of course, not enough of outdoor life, and the girls were really confined (out of doors) to croquet, and they laced and wore hoop skirts and were old-fashionedly feminine. But the boys thought them perfect and went to church and Sunday School and the "sociables" and picnics largely on their account. No one was what we call socially ambitious, and all seemed comparatively content. As I look back, I can see the beginning of social strata, but these were based almost entirely on financial standing. It seemed to me that the families who had pews on the central aisle of the church, well toward the front, carried themselves with a faint superiority toward those behind them and on the side aisles.

On the whole, however, the men and women who have transferred themselves or who have been transferred elsewhere from such beginnings have proved progressive and adaptable. Many of them hold high places and have fitted readily into much more complicated environments. Many of them have, in fact, gone on and far surpassed those who have spent their early life in 


\section{FIGHTING THE INSECTS}

large cities. But there are thousands and thousands of them who have simply taken the small town life into the cities. And it must be said that there are many city-bred people who seem to prefer or at least do confine their social activities to the simple church life, somewhat like that of the little towns. Perhaps this is best all around, but I confess to a not unmalicious enjoyment of a passage in a letter received recently from a New York friend who found herself temporarily and more or less accidentally in contact with such an environment, and who is still young:

"Anyone who thinks that good, smug, virtuous young people are no longer extant should see that bunch up there-some five hundred of them, under thirty-five, women and men, and all of them vitally interested in the church and all of them spending most of their time at the church. Every evening in the week is alive with some activity and swarming with people. They are all half-baked and without any background and rather blind, but nice. New York as I know it, or as you know it, or as anyone I've ever known knows it, doesn't exist for them. To me they are a brand new chapter and as such interesting, and they were very nice to me. I felt like a pilgrim in a far land, and I wonder if I seemed as unique to them as they to me. They don't smoke or drink. After their activities in the church they foregather at a restaurant on Broadway, where the upper floor is reserved for the 'Guild,' and eat ice cream (vanilla) and drink lemonade and sing the good old songs in loud voices and off the key. The men are rather handsome and the girls, most of them, pretty, and they look like other people, but they aren't. There is a certain blank quality in them on which I can't put my finger. It is a little the same quality that one feels in most clergymen."

Of course my friend who wrote this is much younger than I am and didn't have the "advantages" of my early education, and I wonder whether the people she describes are not happier than she is. 


\section{Chapter II}

\section{S}

THE boyhood days at Ithaca and at Cornell were finished, and I was at last starting out on my own. It is true that I had helped a little towards the earning of what was called my education by working occasionally on the University farm at the munificent wage of ten cents an hour, and that I had also worked a bit in the University Library on the annual dusting of the books, and a very little at the delivery desk, at the same rate of pay.

One incident of the latter employment stands out in my memory. A young student (I think he was a Sophomore) came to the desk one day and asked me whether the Library contained a periodical known as the Revue du Demi-Monde!

But now I was to be entirely on my own. I stopped in New York City on my way to Washington. Most of my mother's family lived there. Two of her brothers, Horace K. and Francis B. Thurber, were the heads of a great wholesale grocery house, one of the largest in the world, with branches in London, Bordeaux, Calcutta and elsewhere, and my brother George was living with the head of the firm. There were three incidents connected with my New York stop that may be worth telling. Uncle Horace, austere, absorbed, religious man that he was, laid down his breakfast newspaper, went with me to the front door and 


\section{FIGHTING THE INSECTS}

shook hands, saying as a farewell: "Well, my boy, perhaps there is something in the world that is bigger than business, and perhaps some day you will be a bigger man than I am." A younger brother of his, Abner G. Thurber, lived over in Brooklyn. His farewell to me was quite different. He walked out of the house to the street and, taking me by the coat lapel in a confidential way, he said, "Old boy, if you ever get into a scrape, and don't want your mother to know about it, and need a friend, call on me." That went to my heart. That uncle surely knew young men. But the incident that interested me most was that my dear old grandmother, who was then living with my Uncle Horace, remarked to her son and daughter-in-law after I had left, "Yes, Leland is a nice boy, but I do wish that he was not in such a trifling business."

The journey from New York to Washington was especially interesting since the train passed from New York across New Jersey into Pennsylvania, and thence through Delaware and Maryland, before reaching the District of Columbia. That fact in itself was quite exciting to an up-State New York boy who had never been out of his own state except to the Philadelphia Centennial. And then it was quite interesting when, at Baltimore, the engine was unfastened from the train and the train itself was drawn across the city by a chain of mules, led by one extremely intelligent old white horse, to be met on the other side of the city by another engine and pulled on to Washington, forty miles away. Later I was to know Baltimore very well, as may appear in subsequent pages.

In the class behind me in Cornell, there was a joyous, sandyhaired, freckled youth, named J. McK. Borden, commonly known as "Mac" or as "Judge." He had graduated the previous June, and had gone to Washington to become a draughtsman in 


\section{THE STORY OF AN ENTOMOLOGIST}

the topographic division of the Post Office Department. He was the only person I knew in Washington, and I had written to him, asking him to engage a boarding house for me, and he had answered that I could room with him over Kennedy's grocery store at I209 F Street. I reached Washington about dinner-time, and went at once to Borden's boarding house at the northwest corner of F and I $3^{\text {th }}$ Streets. I found Mac and his mother and his stepfather at dinner, and after dinner we went to our lodgings. The stepfather, Colonel Carter, and Mrs. Carter, Mac's mother, had rooms directly below us.

The Carters were most interesting people. The Colonel was a politician, and I think that his wife, who was very handsome, was something of a lobbyist. The Colonel, although a Virginian, was a Republican, and was called a "Carpet-bagger" by the Democrats, since he had gone to Louisiana after the War, and had become Speaker of the State Legislature. He held that post at the time of the Warmoth riots, in the course of which the Lieutenant-Governor, a negro, was killed. The Colonel was very hard of hearing, and once told me that that disability had been of great service to him in presiding over the Legislature, since he could recognize anyone he pleased and lay his inability to recognize the first man who arose to his deafness. He was a good stump speaker, and was used by the Republican Party as a campaign orator. After the election of President Garfield, he was rewarded by an appointment as Minister to Venezuela. After Garfield died, however, in the summer of $188 \mathrm{r}$, he had to resign, and was succeeded by some other man appointed by President Arthur.

The Colonel, I am afraid, was something of a poseur, and had greatly impressed his wife and his stepson with his importance. I came into the room one evening and found him playing euchre with Mac, and with one of Nick Carter's (no relation) dime 


\section{FIGHTING THE INSECTS}

novels open on the table beside him. As I came in, Mrs. Carter put her finger to her lips and said, "Be quiet, the Colonel is composing a great speech."

I should like to tell more about the Carters, for the type was new to me, and was most interesting. My education as to people was beginning. But this is the story of an entomologist rather than of a Northern boy who was meeting Southerners for the first time.

The next morning (it was the thirteenth of November, 1878 ) I walked down I $3^{\text {th }}$ Street to the old building of the Department of Agriculture on the Mall, which, it will be remembered, shut off all the north and south streets between the Monument and the Capitol, except Four-and-a-half, Sixth, Seventh, Ninth, Twelfth, and Fourteenth. It was an ugly, old, red-brick, mansardroofed building of the architectural style not uncommon at that period, and, although not large, it housed the whole Department. The Weather Bureau had not yet been added to the Department, and was still under the control of the Signal Service of the War Department, and, in fact, the Department of Agriculture comprised only a division of Chemistry, one of Botany, one of Microscopy, one of Statistics and one of Seed Distribution. Of these the latter was by far the most important. On the second floor there was a museum which contained principally models of fruit (especially apples) which had been made by and were under the charge of the former entomologist, Townend Glover. I found the Division of Entomology in two rather large rooms and a small hall-room at the west end of the Museum. I have called it the Division of Entomology, but as a matter of fact it was not called a "Division" until some years later.

I have told the story of those early days in my "History of Applied Entomology" (Smithsonian Miscellaneous Collections, vol. 84, 1930). Professor Riley was then thirty-five years of age. $\mathrm{He}$ 


\section{THE STORY OF AN ENTOMOLOGIST}

was about five feet ten inches in height, and was slender and active. He looked more like a poet or an artist, or possibly an actor, than a man of science. I had seen him six years before at Ithaca. He greeted me with sufficient cordiality, and introduced me to his only other assistant, Theodor Pergande, a little German of forty, with a heavy brown beard, who spoke fluent but rather ungrammatical English, and who had charge of the rearing of the insects and the making of the notes. Pergande was conscious of his poor English, and was anxious to better it in order to make his notes more readable. Knowing that I was college bred, he consulted me as to the best way to bring this about. I suggested that he should read the masters of English style. Some months later I discovered that he had been reading Spenser's "Faërie Queene" and G. W. P. James' novels. There was a distinct difference in the wording of his notes. For example, a record of the biology of, let us say, a species of Smerinthus would begin: "The sun was setting behind the distant hills when a solitary horseman" ... and so on, and so on. But there will be more of Pergande later.

Much to my disappointment, I found that Professor Riley wished to use me at the beginning more as a clerk than as a scientific assistant. The typewriter had not come into use, but for a few weeks I was able to take his dictation in a bastard shorthand that $I$ had invented during college lectures, and to write his letters by longhand.

At the end of three or four weeks, however, he asked me to prepare for him a manual of silk culture, which I did without much trouble, after consulting the books on the subject, both French and Italian, and the Bulletin was published under his authorship.

Life in Washington in those early days was intensely interesting to me, but I much doubt its interest to other people. Pro- 


\section{FIGHTING THE INSECTS}

fessionally I hadn't much chance. In those days it was the custom of scientific men to take all of the credit for work done by their assistants. This was considered quite ethical, in fact, the proper thing to do. The assistants accepted the situation, not because it was right, but because there was nothing they could do about it. I seldom looked at a scientific paper published during that period without wondering who really wrote it. A most interesting and lengthy treatise could be written under some such title as "Hidden Bibliography." But it would require enormous research, and probably would involve some injustices to famous names. I heard the question argued as late as 1895 at the Cosmos Club, and remember that Major C. E. Dutton, a very well-known seismologist, and Colonel Garrick Mallory, an equally wellknown ethnologist, were especially vehement in their claims that the chief owns the brains of his assistant, who is paid for their use. It is true that both these men were army officers, and perhaps this accounted for the vehemence, but the same attitude was held by many other heads of investigatory work.

From this prevalent fashion, it resulted that my chief signed everything I wrote, and often without changing a word. It is true that I did not do much during the six or seven months that followed, since Professor Riley resigned in a fit of temper, and my old teacher, Professor Comstock, was appointed as his successor.

Quite recently, in looking over some letters I wrote to my mother during these early days, I found one written in $\mathbf{I} 88$, which expresses, rather sententiously, my ideas at that time on this subject. I said, "Whenever you see a treatise by Professor or Dr. So-and-so in which he says in his introduction, 'I cheerfully acknowledge the help of my assistant, Mr. - ', or words to that effect, you can make up your mind that the professor wrote the introduction and the assistant the treatise."

$$
\text { [30] }
$$




\section{THE STORY OF AN ENTOMOLOGIST}

Of late I have been thinking over the situation as it appeared to me then. In other words, I have put myself in the place of the assistants of those times, and I must confess that they exaggerated their own importance. There is much to be said for the director. But undoubtedly, after I became a chief myself, I went very far in the other direction. I had suffered so much from what I considered to be bad treatment that I was very keen to give everyone his just dues. In fact, John B. Smith, who had become State Entomologist in New Jersey, wrote me once that I went to an absurd extreme in that way. But I think I was right, and, whether my example helped or not, there has been a great reform. Of course nowadays a chief is not likely to hear complaints of that kind, and in the last thirty or more years but one complaint has ever reached my ears so far as my own personal actions are concerned. That was rather an interesting case, and I am inclined to tell about it.

About 1898, especially after the Spanish-American War, I became greatly impressed by the extraordinary extent of food pollution brought about mainly by the house fly, particularly in cases where large numbers of people were concentrated for more or less temporary purposes, and I began an investigation of the insect fauna of human excreta. It was a very disagreeable subject, but, as I thought, a very important one. I could not do all the work myself, but I planned it, and sought the assistance of many people in different parts of the United States. Most of them helped me by collecting the insects that were attracted to exposed food, but many of them collected the insects that were attracted to excreta, either in the open or in privies, and still others, specialists in the different groups, named the collected material for me. Of course the help of all of these men was thankfully acknowledged, and each one was mentioned personally. There was one young man, F. C. Pratt, an Englishman, 


\section{FIGHTING THE INSECTS}

then in the employ of the Bureau, who was especially apt in rearing insects, and he did a great deal of the work in the actual breeding of the specimens. When I came to publish the paper, which, by the way, was rather lengthy, I called especial attention to Mr. Pratt's work, and, as I thought, treated him rather handsomely. Many years later, however, after his death, I learned that he had complained to certain other people that I had not treated him justly and that he should have been the joint author of the paper, although, as a matter of fact, he had nothing to do with its planning, wrote not a word of it, and did not appreciate its importance until he had read it.

Comstock, who had not been married long, was building a little house on the Cornell campus. He got leave of absence from the University and came to Washington, where he worked peacefully and successfully for two years. His salary as entomologist was, I think, two thousand dollars a year. His wife was appointed a clerk, and was given twelve hundred dollars a year. They lived economically in rooms on F Street, ate at restaurants with very reasonable prices (in those days a good dinner cost twenty-five cents), and saved as much money as possible to help meet the payments on the little house building at Ithaca. We lived on terms of the greatest intimacy, ate together, and at least once a week went to the theater. They met the financial demands from Ithaca so carefully that when we wanted to go to the theater it was frequently necessary for me to pawn my watch to buy the tickets. I believe that Professor Comstock had no watch to pawn.

We worked very ardently, and I wrote many papers, some of them based on careful, original investigation. Much to my discomfort, Comstock cheerfully assumed the authorship of these papers, and I entered no protest. I had worked up two of them 


\section{THE STORY OF AN ENTOMOLOGIST}

as a basis for a thesis for a Master's degree at Cornell, but when Professor Comstock asked me to let him publish them in his Annual Report, I consented, and thus their titles do not appear in my personal bibliography. But I enjoyed the work, and we published in Comstock's Annual Report some excellent articles about the life histories of several important crop pests.

It was then that I first became interested in parasitic insects, and I will tell how this came about when I come to write about the subject of natural control by parasites and predators. The study of these little creatures and of their extraordinary interactions fascinated me. It is an interest that has continued all my life. Comstock, at that time, thought that he had tuberculosis, and I believe that he did have it in an incipient form. He was thin and pale, coughed frequently, and I often noticed that his handkerchief was spotted with blood. He thought it necessary to go to Florida in search of a milder winter climate, and it was there that he began his study of the scale-insects, which proved to be of great value, and which soundly established his early reputation. Much of his material was sent to Washington, and from it issued many parasites. I studied these, named, described them, and published my first big paper over my own name under the title "Report on the Parasites of the Coccidx," etc.

It is interesting to remember that while the Comstocks were south I made my first field trip. A planter at Portsmouth, Virginia, who was growing a large acreage of timothy grass, sent to Washington an appeal for help against the army worm, which was threatening the complete destruction of his crop. I boarded a Potomac boat and went down to Portsmouth by night, and then by carriage out through the swampy region to the plantation. It was then that I had my first sight of the true Southern negro. It happened to be Saturday, the big market day in Portsmouth, and I met hundreds of colored families in their 


\section{FIGHTING THE INSECTS}

mule carts travelling in from the country to market. When I reached the farm (or plantation) I found no mansion, but simply an overseer's house, and the overseer himself was a plain, uneducated man, who at once took me out to the infested fields. The scene was extraordinary. Over many acres there was hardly a stem that did not bear one or more of the voracious caterpillars. In those days there was little that could be done except to stop the march of the army by ditching or something of the sort. But the first caterpillar that I examined had some white eggs on its back, and these I at once identified as the eggs of a tachina fly. This was encouraging, and I examined other caterpillars. In fact, I spent four hours in the field trying to find a caterpillar that did not bear the parasite eggs, but without success. Thus I was able to assure the overseer that although there was no help for the bad damage that had been done, it would not continue, and that probably no more army worms would be seen in that vicinity for some years to come.

All this had been done in the morning, and we returned to the overseer's little house, where the trap was waiting to take me back to Portsmouth. The overseer suggested that perhaps I would like something to eat. Not wishing to put his household to any trouble, I suggested that I might like a sandwich.

"A sangwich?" he said. "Do you know that I saw one of them things once. I had a big trip to New York, and went down to Coney Island, and there I saw one of them things. I cayn't git you a sangwich, but I kin rustle up some corn pone."

And then I made my first acquaintance with the Southern corn pone and hog. It seemed to me very disagreeable, soggy and unappetizing, but I was hungry and I ate it. I have since learned to like corn pone as it should be cooked, but this was the first experience with it, and it did not taste good to the boy from Central New York. 


\section{THE STORY OF AN ENTOMOLOGIST}

A detailed account of those early days would not be of especial interest, but people under the present Civil Service cannot realize the conditions that existed then. Appointments in Washington below the rank of Cabinet officers, and possibly their immediate entourage, were made solely by what was called "congressional influence." Persons wanting government jobs appealed to their members of Congress, and a considerable part of the time of members was taken up in going from department to department to look for jobs for clamoring constituents. And the appointees themselves were constantly trying to strengthen their hold upon these members to fix their continued backing. With a change of administration, everyone was fearful, and there was a decided overturn in the office-holders.

I remember vividly that Cleveland's first election marked a radical change. The Democrats had not been in power for many years. One day while I was sitting at my desk, a shadow fell on the papers in front of me, and I looked up to find a tall, gaunt Southerner in a white linen duster, with the corners of his mouth stained with tobacco juice. He grinned at me and said, "Don't disturb yourself, sonny. I'm just lookin' around tryin' to find a desk that will suit me, and I rather think that yours is about right." And then, too, I remember that it was considered the just thing for every employee to contribute to the election funds of the party in power to the extent of one month's salary. For example, I was asked to give one hundred dollars to the Republican Congressional Fund during the first year I held office. The man who solicited these funds was the private secretary to the then Head of the Department. Thus it was equivalent to an order. I paid it the first time, but never paid it later. It is only fair to state, however, that during my whole residence in Washington of more than fifty-three years I never knew of a single case in which a scientific man lost his position for any reason 


\section{FIGHTING THE INSECTS}

other than incompetency. As a matter of fact, their politics were never asked. I doubt whether in later years any of the Cabinet officers knew the politics of their subordinates any more than they knew their religion, except possibly of the few men immediately surrounding them. But what a great relief it was, not only to the government employees, but even to the members of Congress themselves, when the Civil Service reformers, headed, I remember, by George William Curtis, finally secured the passage of the Civil Service Law, and the Civil Service Commission was eventually established!

But the Civil Service Law is by no means perfect. I was the head of a Bureau for many years, and the Bureau grew rapidly in size. My personal acquaintance with entomologists and with teachers of entomology was very great, and I always felt that I could pick my assistants much better than any Commission with its series of examinations. And then, too, I always objected to the clause in the law that provides for State representation in the Civil Service, since it was always obvious to me that the Government wanted the best men and women utterly irrespective of the states in which they voted. In the early days, meeting from time to time socially with General Black and John R. Proctor, each of whom for a time was President of the Commission, I always tried to discuss this question. General Black, I remember, defended the clause, but Proctor agreed that I was right.

I should like to say more about the poor clerks and the lazy clerks of those days. But I must confine myself more to scientific matters, and more especially to entomology.

It was difficult to learn the exact names of many of the insects we were studying in Comstock's time. I had taken up the parasitic Hymenoptera, and Comstock had taken up the scale-insects. 


\section{THE STORY OF AN ENTOMOLOGIST}

When we were studying beetles we got the names from Henry Ulke, who was an amateur in science, but who was locally famous as a portrait painter, and at the same time was a pianist. When we wanted to know the names of the little flies we sent them to Edward Burgess of Boston, who was also more or less of an amateur, but whose real interest during his later years was centered in the designing of yachts. It will be remembered that he was the designer of the famous Mayflower I, which won its race against the British competitor some time during the ' 80 's. We were constantly rearing little moths, and the American who then knew the most about these forms was Professor C. H. Fernald, of Amherst, Massachusetts. During one of his summer vacations (I think it was in I880) Fernald and his wife came to Washington and spent part of July and August in the Department of Agriculture, working in the same room with me, Comstock and his wife being absent in California, where Comstock had gone to round out his knowledge of the scale-insects of the United States. The Fernalds were delightful people, Professor Fernald having a somewhat boyish humor that filled me with joy. At that time beggars and selling agents of all kinds had the run of the government offices, and I shall never forget the dear old Professor's method of getting rid of them. When an unmistakable beggar entered the room, Fernald would immediately jump to his feet, rush over to him, grasp him by the hand, and say, "How do you do? I am so glad to see you. How did you leave the folks at home?" Almost invariably this so embarrassed the beggar that he turned and left.

And this reminds me of a story that was told at that time of a certain high official of the Treasury Department, named Trenholm - a very dignified and cultured South Carolina gentleman. He had issued strict orders that no beggars were to be allowed to enter his office. One day a deaf mute slipped by the 


\section{FIGHTING THE INSECTS}

door-keeper, went up to Mr. Trenholm's desk and laid before him a card on which was printed the deaf-mute alphabet. The high official looked up, greatly irritated. He realized that he could not say anything that would be understood, so he called to the door watchman, "John, convey to this mendicant the idea that he cannot vend his wares here." Taking in the situation, John resorted to the sign-language. He patted the man on the shoulder, pointed to the door, and kicked violently with his foot. The beggar understood and left.

And so time went on for the better part of two years, and then came a Presidential election. The Republicans won, and on the fourth of March James R. Garfield was sworn in as President. He appointed a new Cabinet, and a new Commissioner of Agriculture. The Department of Agriculture was not then represented in the Cabinet. It was a so-called independent department. The new commissioner's name was George B. Loring of Massachusetts, and he was immediately overwhelmed by a mass of demands from all over the country that C. V. Riley be reappointed U. S. Entomologist. Although Comstock was a good man and had done very good work, the political pressure was too strong and Riley was reappointed, Comstock going back to Ithaca with a sop of one thousand dollars, given to him for the completion of his work on scale-insects.

I have told the story of this period rather fully in my "History of Applied Entomology." It is only necessary to say here that although I fully expected to be discharged and to go to New York for my medical studies, I was retained and was soon designated as first assistant.

But before Riley had fully made up his mind about me I was sent on three field trips. The first was to Illinois, Indiana and Wisconsin, to investigate serious outbreaks of the army worm. I started from the old Pennsylvania Railroad Station at 


\section{THE STORY OF AN ENTOMOLOGIST}

Sixth Street, and as it happened was only a short distance behind President Garfield and Secretary Blaine when the President was shot in the back by the crazy office-seeker, Jules Guiteau. The station was crowded at the time, and many people did not realize the situation. My train was due to start, and I felt that I would only make one more in the mass of curious people that would get in the way, and so I boarded the train and left for Chicago. On my return from that trip I was sent south, this time to investigate damage done by insects to the rice crop on certain of the sea islands off the coast of Georgia. This was a fascinating trip. I was the house guest of Colonel Scriven in Savannah, and the trip was full of delightful and interesting experiences. It was also successful from the scientific point of view, and I accumulated a lot of notes, afterwards published in one of Riley's reports, which constituted our first authentic information concerning the insect enemies of this important crop.

One evening, sitting on the veranda of the Scriven mansion in Savannah with the Colonel and his wife, eating delicious rice-birds on toast (a heavenly dish), Mrs. Scriven, a beautiful and charming lady, laughed girlishly when I asked about the Colonel's military title. She told me that he had been in command of the defenses of Savannah. They had expected an attack by the water-front, so the Colonel had spent many weeks filling up the channel of the Savannah River with all sorts of obstructions. Finally, however, the army of General Sherman captured the city by an overland attack. Then she said with malicious glee, "The only thing that the Colonel's obstructions in the river ever did was to wreck one of his own rice-boats coming back from the plantations some years after the war!"

I was about to state that this was my first trip south since my journey down the Potomac to Portsmouth. But there was 


\section{FIGHTING THE INSECTS}

another trip during the Comstock régime that should be mentioned.

One day Professor Comstock came to me and said that he had just met an interesting travelling Englishman, who was apparently a man of wealth and who was going south by way of New Orleans to Mexico. He was writing a book on his travels and needed a secretary for an hour or two every evening. Comstock recommended me for the job, and I went that night to Welcker's Hotel, where I found the English traveller. He was a man in the late fifties, rather short, with a bushy beard, and I saw at once that he was a character entirely new to my experience. He began to dictate to me his experiences in Canada. It was in the early spring, and he had just come from Montreal, where he had seen the ice carnival, about which he was very enthusiastic. After dictation he invited me to dine with him. He was a good diner-knew good things, and liked them.

For some days we followed the same program. He spent his days going about the city, visiting Congress and the museums and other public institutions. He was a chatty man, and occasionally picked up some American and invited him to dine with us (I dined with him every day). I remember that one day he had invited a curious old German professor, an ethnologist, who was connected with the Smithsonian Institution. When the man appeared at the hotel his polite opening remark was "So, Mr. — , you are an Englishman. Do you know I consider your Queen a very ordinary old woman?" The Englishman's tact was quite sufficient, and the incident passed off pleasantly enough, but I have often wondered what would have happened had the host been a less tactful man.

At the end of a week or so Mr. — asked me whether I would go to New Orleans with him. It so happened that complaints had been received at the Department of much damage 


\section{THE STORY OF AN ENTOMOLOGIST}

that had been done by a borer in the stalks of the sugar cane, but there were no funds that could be used for investigation, so the Englishman's proposal to pay my expenses was gladly accepted, and we started south together.

Some years afterwards the Englishman published a book about his travels around the world, and I looked up a copy in one of the libraries, reading with great interest the part that related to the time when I was with him. It was truthful in the main, but the facts were varied from time to time, probably in order to make it more interesting. For example, the passenger train ahead of us going through the Carolinas was purposely derailed, plunder being the probable object. When we arrived at the spot in the middle of the night we were held for a long time, and finally were put out of our train, and had to walk until we had passed the derailed train, mounting an emergency car on the far side to be carried to the nearest town. The car, in which we were placed on the emergency train was a freight car, lighted by a lantern, and partly filled with the more important luggage from the wrecked train. The conductor and the engineer of that train were binding pistol wounds they had received after the derailing. Altogether it was rather exciting. The book account simply made all this happen to our own train-not to the one ahead of us.

Another time, when we were going through the flat land between Mobile and New Orleans, we saw that the marshes were on fire some miles away. As described in the book, this incident was illustrated by a full page in vivid color, showing great flames and dense smoke, with the legend, "The Pampas on Fire Near the Gulf of Mexico," and the text stated that the Americans in the train, with their accustomed gambling propensity, were laying wagers on whether we should get through alive. But enough about the book. It can doubtless be found without 


\section{FIGHTING THE INSECTS}

difficulty, although I am not telling its name nor that of its author. We finally reached New Orleans, and I was fascinated by the still very Frenchified city (this was in the spring of 1879). The French Quarter was still perfectly French, and, in fact, on one side of Canal Street, it was as though you were in France.

It so happened that my chum, Mac Borden, had spent his early boyhood in New Orleans. One thing he said to me before I left Washington illustrated the inconsequence of some of childhood's most vivid recollections. He said, "When you get to New Orleans, go to Number —- Esplanade Street. Go through the iron gate, down the brick walk to the front door of the house. Ask for permission to go through into the back yard, and then go down the brick walk to the stable. When you get to the stable door count four rows of brick from the left edge of the door towards yourself, and then three rows to the left, and see if the brick is still there that has a little hole in it where I fell down and broke off my tooth."

We went to the old St. Charles Hotel, a distinctly American institution, and paid six dollars a day each, American plan, which, of course, included our meals. But the food did not suit my English companion, and we dined every day at a famous French restaurant on Canal Street. My economical mind was shocked at the amount of the bill, which was seldom less than fifteen dollars. We went to the French opera, and it must have been then in its prime, for the performance was very good. The audience was brilliant, and the conversation around us was wholly in French.

My English companion had been spending money like water, apparently without the slightest regret. One day, however, we boarded the ferry-boat to cross the Mississippi to Algiers. We decided not to leave the boat, and returned to New Orleans 


\section{THE STORY OF AN ENTOMOLOGIST}

without paying another fare. It delighted my companion to find that we had crossed back and forth on the single fare, and so we stayed on the boat for several hours, going across the river and back again. I don't think that he saved enough money to pay for the dinner that night, but we had a long and interesting conversation. Among other things we talked about the Bible. He was a Bible student and said that he understood all the texts perfectly. I remarked to him, "How would you explain the one that goes 'Ye are the salt of the earth. Now if the salt hath lost its savor, wherewithal shall it be salted?'"

"Why," he said, "that's very simple. Suppose that you and a lot of other chaps were the aristocracy of a certain country. If you were not perfectly moral and upright, and all that sort of thing, what the deuce would become of the country?"

It was a wonderful experience for me, and with all of his apparent eccentricities I admired the Englishman greatly. When he had to go on to Mexico he asked me to go with him, but I had my work to do in Louisiana, and this, together with the fact that there was to be a change of administration in Washington, made me think it wise to decline. I gave him a letter of introduction to a classmate of mine who had taken a minor engineering job in the City of Mexico, and he acted as the Englishman's secretary for a few weeks after his arrival.

Then I went into the Bayou Têche country to a large sugar plantation, the owner of which had appealed to Washington for help against a beetle (Ligyrus) that was boring into the bases of the cane stalks. I found that I had known the son of the planter at Cornell. He was W. J. Thompson of the class of 1875. His father, an austere, bearded man, had come from Chicago, and had bought this big plantation on the Têche. He told me that in those days (possibly it is so now) sugar planting was something of a gamble. Two years out of three the crop 


\section{FIGHTING THE INSECTS}

might fail, but the profits on the third year would exceed a hundred thousand dollars, and this enabled him to carry on. Here is a curious instance of the importance to some people of little technical points. The elder Thompson said to me the first night I was there, "So you are an assistant to Professor Comstock? I don't believe that he is a very good entomologist."

I said, "Why? What makes you think that?"

"Well," he said, "I sent samples of this beetle to him, and also to the great entomologist, Professor Riley. Comstock wrote me that it was Ligyrus rugiceps and Riley wrote me that it was Ligyrus ruginasus." (Henry Ulke had identified the beetle for Comstock, and E. A. Schwarz had determined it for Riley.) I wonder if Mr. Thompson thought that the proper Latin name had any effect upon the remedial treatment.

The next few days we spent in the cane fields. It was a new crop to me, and I learned a lot.

One interesting incident connected with my stay at Calumet Plantation was a visit to Joe Jefferson, the actor, who had a house in the swampy woods some thirty miles away. It does not seem to be generally known among the thousands of admirers of Jefferson that he had this place in Louisiana, and that he spent his time there painting swamp landscapes. As I recollect, the canvases were not especially good, but Jefferson was cordial to us, and was quite as charming off the stage as on.

On my return to Washington, I wrote a circular about this damage to sugar-cane by Ligyrus, and it was published by the Department, of course over Comstock's signature.

There was one more trip to the south in those early days, and it happened after my return from the Georgia rice-fields. The same old northern army worm turned up in great numbers in the wheat-fields of northern Alabama, around Huntsville, 


\section{THE STORY OF AN ENTOMOLOGIST}

and Professor Riley sent me down to investigate. At Huntsville I met the editor of the local newspaper, who introduced me to a number of charming gentlemen with various titles, such as Judge, General, Senator, and so on. They treated me with the most perfect courtesy, and gave me the highest opinion of the Southern gentleman. The insect outbreak was, of course, a temporary one, and has probably never been repeated down there since. But it gave me a very emphatic opinion of the value of natural enemies. At one point the marching army of caterpillars had met a rather deep railway excavation, and had fallen in by the millions, so as to cover the rails and fill the excavation to a depth of several feet. Such a sanguinary scene I have never met with since. Carnivorous ground beetles, predatory bugs, Tachina flies, Ichneumon flies, and other predators and parasites had flown in, evidently from many miles around, and were either feasting upon the caterpillars, or laying their eggs in or on their wriggling bodies.

Similar things have been noticed by other observers, but no one has yet explained how these carnivorous insects discover from long distances the presence of the food in such profusion.

While I am thinking of the South, I remember that there was another trip during this same general period. There was an international celebration called The Cotton Exposition, that was held in New Orleans in $188_{4}-85$, and I was sent down by Professor Riley to install a rather elaborate exhibit illustrating applied entomology. John Boutelle of the Coast and Geodetic Survey, who knew New Orleans well, gave me a letter of introduction to Victor Béro, who kept a delightful little French restaurant on the Rue Bourbon. While Americans who liked French food went there, the clientele was largely French, and French was the predominant spoken language. There were not 


\section{FIGHTING THE INSECTS}

many tables, and the floor was uncarpeted and sanded. Béro himself was a well-known character in New Orleans, and a man of considerable weight in the community. He gave me a room in a building adjoining the restaurant, and I took all of my meals with him, to the great improvement of my poor college French. I spent a very enjoyable and improving month, and a large share of my pleasure was due to Victor Béro.

Fifteen or sixteen years later I entered New Orleans from the west. I had with me three travelling companions whom I had met on the through train from California. We reached the city about nine o'clock at night, registered at the St. Charles Hotel, and then went around to Victor's restaurant to dine. The table d'hôte dinner was over, and so, with the consent of my companions, I asked Victor to get us up something nice. And he did. There was an inimitable French soup, a broiled red snapper, a canvasback duck, a wonderful salad and an ice. And there were some excellent white and red wines as well, followed by coffee and cognac. I asked for the bill (mind you there were four of us), and when Victor himself brought it (it was twelve dollars) two of my companions (not very well-bred men) protested rather vociferously about the amount. Victor shrugged his shoulders and said calmly, "You will pay me nothing," and walked back to his desk. I rushed after him, explained the men were not friends of mine but simply compagnons de voyage, and insisted on paying the bill.

Victor made money. He bought a farm, on which he raised his own poultry and vegetables for his restaurant, and he bought a hotel, which he managed on the side. But his health failed, and he died. Some years afterward, I went to New Orleans again, and of course to the old place on Bourbon Street. It was greatly changed. More tables had been put in, and the sanded floors no longer existed. The room was filled with 


\section{THE STORY OF AN ENTOMOLOGIST}

diners, nearly all Americans, and the French atmosphere was largely non-existent. However, I took a seat, and remarked cheerfully to the waiter, "Il y a beaucoup de monde ici ce soir."

He scratched his head and said in Hibernian English, "This is a French place all right, but I don't understand the lingo."

Possibly this anecdote illustrates well the change that had come to New Orleans.

Now followed a long period of about thirteen years under Professor Riley. He seemed gradually to rely upon me more and more, and although we had a number of other assistants, he soon made me the principal one. His health was not good, and he travelled a great deal, leaving me in charge of the office at Washington during his many and frequently long absences. Gradually he allowed me to publish shorter articles under my own signature, and in 1889 he was able to begin the publication of a periodical journal known as Insect Life, intended at first to be issued monthly, but which became more or less irregular. However six volumes were published under our joint editorship. During the years of Professor Riley's incumbency of the office of Chief of the Service (I88I to I894) the work was interesting enough. Admirable annual reports and many bulletins were published, and, in fact, it was a period of marked progress. The establishment of the journal just referred to, the founding of the Association of Economic Entomologists, the establishment of State Experiment Stations, under the so-called Hatch Act, and the consequent impetus to the teaching of entomology in the state colleges and universities, all contributed largely to this result.

The most dramatic episode of this period was the extraordinary success of the introduction from Australia of a little beetle of the so-called lady-bird family that utterly destroyed the fluted scale 


\section{FIGHTING THE INSECTS}

that was threatening to exterminate the citrus orchards of California. Later we will consider the whole question of the practical use of insect parasites and predators, and this particular introduction will be mentioned. But we may well say something more about it here.

The scale-insect in question was very difficult to kill by means of washes, since the female carried her eggs in a dense mass covered by fluted wax, that was impermeable to nearly all liquids, and treatment by hydrocyanic acid gas had not been invented. Two of our agents, Albert Koebele and D. W. Coquillet, had been spending their time in different experiments, searching for some means of control. Riley, by correspondence, had learned that the original home of the scale was probably Australia, and that, although it occurred there, it did little damage. He urged one of his correspondents, Mr. Frazer S. Crawford of Adelaide, South Australia, to try to find out whether the scale had insect enemies. Crawford succeeded in rearing a little parasitic fly, and sent specimens to Washington. Then Riley wanted to go to Australia to send this parasite over in large numbers. But the regulations would not permit him to do so. Eventually he secured permission from the Department of State to send two men over under funds that had been appropriated for United States representation at an exposition about to be held in Melbourne. Koebele, a remarkable collector, was sent over to attend to the parasites, and another assistant, F. M. Webster, went along to prepare a report on agricultural features of the exposition. This last was a quid pro quo to compensate the exposition fund for its payment of Koebele's expenses.

In the meantime Coquillet at Los Angeles had prepared an orange tree, well stocked with scales and covered by a close gauze tent, to receive the parasites.

Koebele found the parasitic fly in small numbers, but he also 


\section{THE STORY OF AN ENTOMOLOGIST}

found the little predatory beetle that was to become so famous. Both were sent to Coquillet.

The results startled the whole biological and horticultural world. In less than a year all threat of damage by this particular scale-insect was a thing of the past. And it was the little beetle that had done the work.

The beneficial insect was known then as Vedalia cardinalis, but the genus was later changed to Novius (by skilled experts). It became generally known as the "Australian Ladybird," and the incident has become an entomological and horticultural classic.

The credit for this fine accomplishment has been disputed by Californians, notably by a prominent citizen of that state named Frank McCoppin, who was the United States Commissioner to the Melbourne Exposition. Moreover, there is a recent tendency in Germany to call all of this assisted natural control work the "Koebele Method." The Germans are rather partial to their own people-quite properly so-and Koebele was born in Germany. The truth is, that the main credit belongs to Riley. I remember with some confusion that when he talked over the plan with $\mathrm{E}$. A. Schwarz and myself we told him that in our opinion there was little chance of success, since Australia was in an entirely different life zone, as well as in the other hemisphere.

In spite of the fact that I was slowly given more and more credit for what I did, I was by no means satisfied; nor was I by any means entirely wrapped up in my work. I made many friends among other young men, in and out of the government service, rode the tall bicycle, belonged to an admirable bicycle club, went constantly to the theater and the opera, and joined a musical society. Many of my friends were German, and I went 


\section{FIGHTING THE INSECTS}

often to their beer-gardens and to their Sängerbund concerts, and in general led a not unusual life.

It may be of interest here to say a few words about music. My mother was a charming singer, and my father had a good tenor voice. Both their families were musical. In college I sang in the University Glee Club, and played the bass viol in the Curtis Society Orchestra. As a substitute I also sang with my mother in one of the church choirs. She was the leading soprano in the quartet, and whenever the bass or tenor or alto was ill, I took his or her part. Soon after I came to Washington, I joined the old Philharmonic Society-a choral society which occasionally gave concerts throughout the winter. It was led by Dr. John P. Caulfield, an Irishman, who was a doctor of music from the University of Dublin. I remember that we sang several oratorios, and on one occasion, with great success, Rossini's "Stabat Mater."

In fact, it was through music that I met my wife. She was a girl of twenty-one and had a glorious soprano voice. The old Philharmonic Society died and was succeeded by the Washington Choral Society under the leadership of Harry Sherman, a man famous in musical circles in Washington at that time. I had met Miss Clifton, and at the opening meeting of the Choral Society I discovered her among the sopranos, so during the first winter I took her to rehearsals. She was then singing in the Choir of St. Matthews, the principal Catholic Church in Washington. We were married a year later, and in the six years before children began to make their appearance we went constantly to musical things. Every winter we went to New York to hear the Nibelungen Ring at the Metropolitan.

I am bringing in this reference to music to make an interesting psychological point. In spite of my devotion to the best music, there came a time when my liking for it left me sud-

$$
\left[5^{0}\right]
$$




\section{THE STORY OF AN ENTOMOLOGIST}

denly. It happened in the Dresden Opera House, and I think it was in 1905 (I was then forty-eight years old). The opera was "Tannhäuser," and I listened to the overture with all of the old thrills and a deep appreciation of the deep silence on the part of the audience. But after the beginning of the first act I found that I could not stand it, and went out into the open air. From that time for ten years I could not listen to music. This was not physiological as far as I could tell. My health was perfect, and I was conscious of no change until ten years later when I happened to hear an orchestra playing something by Brahms. And then the old love came back. Let the psychologists explain this.

In spite of the fact that Professor Riley was constantly throwing more and more responsibility upon my shoulders, I had a distinct feeling that I did not satisfy him. In fact, I learned later that he told Professor S. W. Williston, then of Yale and afterwards of Kansas and Chicago, that I was by no means an ideal assistant, and, in fact, Williston said that Riley offered him my job. Williston declined with thanks, and I am not sure whether I was lucky or not. At that time, Williston was possibly more interested in the Diptera than he was in his paleontological studies, in which he afterwards became famous and which brought him his election to the National Academy.

At all events, I stayed on, although other positions were occasionally offered to me. I remember that J. A. Holmes, much later Director of the U. S. Bureau of Mines, wanted me to go to the University of North Carolina at Chapel Hill. I remember also that Morris K. Jesup, then President of the American Museum of Natural History in New York, spoke to me about taking a post there, and would have given it to me had the Museum been able to meet my modest financial demands. But they were 


\section{FIGHTING THE INSECTS}

restricted in funds at that time, and the post was given to William Beutenmüller for a few years until the financial weather brightened, when W. M. Wheeler (then of Clark University and later of Harvard) was appointed.

I think that I must have had an idea that if I held to my Washington position I would eventually become Chief. I was not especially ambitious, and had no idea whether I was good at executive work, but I liked Washington and had adopted a kind of laissez-faire policy of life. In fact, it was comparative poverty that finally made me begin to work in earnest. I remember that once David Starr Jordan, in speaking of his college days, used the expression "and we were so helped by that blessed poverty." That was the first time that I ever heard poverty called blessed. But it was a very significant saying, since at least comparative poverty has been the great incentive that has led many men to success of one kind or another. At all events, I began to be more active in my work, and to look about for chances to spread out. These chances, however, were few and far between so long as my Chief was in the saddle.

However, in the spring of 1894 , after rather serious misunderstandings with the then Secretary of Agriculture, Sterling J. Morton, Riley, on his return from a West Indian trip, resigned, and his resignation was promptly accepted. Here apparently was my chance. But the authorities, knowing that I had been what is termed a "loyal assistant," feared that I might be a difficult person, and so they sent out letters to James Fletcher of Canada, to S. H. Scudder, of Boston, and to A. J. Cook, of Michigan, asking for suggestions as to the most competent man to succeed to the office. Rather to their surprise, I think, all of these men recommended me, and in June, I894, I received the appointment as Chief of the Service. 


\section{THE STORY OF AN ENTOMOLOGIST}

As it happened, in the decade following 1889 , four remarkable things occurred. The first was the discovery of the Gipsy Moth in New England in 1889; the second was the finding of the Mexican Cotton Boll Weevil in Texas in 1893; the third was the appearance of the San José Scale in eastern orchards about the same time; and the fourth was the discovery by Ronald Ross of the carriage of malaria by certain mosquitoes. The first three were of tremendous importance to the United States, and involved the loss of many millions of dollars. The fourth was of the greatest importance to all mankind, for malaria, while not so great in mortality as cholera and the plague and certain other diseases, was responsible for a tremendous lowering of vitality and for the bringing about of conditions leading up to mortality from other causes.

Thus the horizon opened up very greatly. I felt that I was no longer engaged in work that might be called of comparatively little importance. One of the four discoveries mentioned above leads naturally to a digression and takes us back to an earlier period.

In the early I880's, being by no means convinced of the certainty of a remunerative career in entomology, I decided to follow my early medical inclination, and at least to gain the degree of Doctor of Medicine. As it happened, the old Columbian University, an institution founded and largely sustained by the Baptist Church (it is now the George Washington University, a non-sectarian institution), had a medical department founded seventy or eighty years earlier. The professors were practically all men who were in medical practice in Washington, and, for the convenience of government employees, the lectures began at four-thirty in the afternoons and continued until ninethirty, after which all dissecting and certain other things had to be done. Office hours for government employees were then from 


\section{FIGHTING THE INSECTS}

nine A. м. to four P. M., so that a medical student after a hard day's work had to eat a hurried dinner and go to a four-thirty lecture. By the time he left the dissecting room it was usually nearly midnight, and he was a very tired man.

There were some mighty good men in the Faculty in those days. The lecturer on anatomy was no less a person than Elliot Coues, a retired army surgeon, and a brilliant man who had made his reputation largely on his work in comparative anatomy. A. F. A. King was the lecturer on gynæcology and obstetrics. He was a first-rate man of a speculative turn of mind, whose fame today rests largely on the fact that as early as $188 \mathrm{r}$ he published a long essay seeking to prove that malaria was a mosquito-born disease. This essay was theoretical, not based on actual experimentation, but it brought together a host of facts and marshalled them in logical order. I remember very well that when he read his first paper on this subject before the Philosophical Society of Washington, he came down to Professor Riley's office and discussed the matter with Riley and myself. To my eternal shame, I confess that we both pooh-poohed the idea, and as a matter of fact, no one took any stock in it until Ross's triumphant demonstration in Calcutta seventeen years later.

Then there was Daniel Webster Prentiss, lecturer on Materia Medica; George W. Acker, teacher of the microscope; J. Ford Thompson, lecturer on surgery, and a brilliant surgeon. I think that I will be pardoned if I tell a little yarn at this point.

A group of us, all students, were told to go to a certain hospital to watch certain operations. The first operation, which was very gory, was the excision of one of the super-maxillary bones, and it was done by a surgeon known among the boys as the "butcher." Half sickened at the sight, we gathered around another table, fearful of what we were going to see. This time the operation was 


\section{THE STORY OF AN ENTOMOLOGIST}

on an Irishman, and was of slight importance. It was simply the removal of a gangrened toe. The patient was partially under the influence of ether, Ford Thompson was operating, and almost with a single flick of his wrist the work was done. So great was the feeling of relief after the other operation that we involuntarily laughed with pleasure. The Irishman, only partially unconscious, had been crooning to himself, and, hearing the laugh, said rather mumblingly, "Docther, docther, cut aff anither one. It amuses the bhoys."

But the work was hard. I contracted malaria, and I married, and the combination of the two things was too much for the medical studies, so they stopped long before I got my degree. But I never regretted them, and my interest in medicine, begun during my post-graduate studies at Cornell, has continued ever since.

In fact, not only have medical studies always interested me, but medical men as well. During the years from 1886 to 1898 , however, I read little medicine (although I used to look over the Lancet and the Journal of the American Medical Association at the Club), and it was not until the epoch-making discoveries of the relation of insects to human disease were announced that I got back into the medical field. Then I pitched in rather strenuously. But I shall tell of this somewhat at length in another place. Medical investigators soon began to realize that not only was it necessary to know mosquitoes well, but that when a disease is shown to have an insect vector, the economic entomologist, by his training, is the man above all others to point out the best way of controlling this vector.

And so, after some years in which I had published articles and books, the bright idea occurred to some of the members of the faculty of the Medical College of George Washington University that I ought to have a medical degree. They pushed the matter 


\section{FIGHTING THE INSECTS}

and succeeded, and in IgI I was given an M.D. Honoris Causa, partly for the work I had done in the college many years before, but mainly because of my later services to public health and my investigations of the insects that carry disease. An honorary degree in medicine is an unusual thing, and I was very proud of this recognition. I later joined the Medical Society of the District of Columbia, and am now on its honorary membership list.

As the force of the Bureau of Entomology grew, its library was enlarged, and it was necessary to employ several trained librarians. I was able from an early date to use these people as readers and so to go through a great deal of medical literature with little loss of time.

Here I should like to revert a moment to the subject of honorary degrees in medicine. Back in the middle of the last century-of course before and later-men were licensed to practise medicine in New York State without necessarily having attended a medical college. They studied in some doctor's office, later passed an examination by State authorities and were then admitted to practise. That, I believe, was the way that my grandfather, Dr. Calvin Howard, of Delhi, New York, followed. At all events, I was delighted to find some years ago that his name was among the few that had been given an honorary medical degree in $18+2$ by Columbian College of Washington. From this old college grew the Medical College of George Washington University. Thus my grandfather was given the same degree by the same college over sixty years before me. 


\section{Chapter III}

\section{$\mathrm{M}$}

Y LIFE in Washington as Riley's first assistant from I88I to 1894 was not so very different from that of many hundreds of other government employees. The scientific aspects of the life have been touched upon in a previous chapter. As to the other aspects, down to the time of my marriage in I886, something really ought to be said. At first there were no scientific societies except the old Philosophical Society, but that soon began to split, and the Biological, the Anthropological, the Chemical, the Entomological, and other societies in increasing number, were formed. The Philosophical Society was not especially interesting to a very young man, and conditions in the office, as described in the previous chapter, were decidedly not such as would compel my serious absorption.

The old high bicycle had made its appearance upon the streets, and it fascinated a lot of us. The Capitol Bicycle Club was founded. Many college-bred men had come to Washington, attracted by the short working hours (nine o'clock until four) and the comparatively good salaries. By making use of the admirable night schools, they expected to get their professional educations in law or medicine without expense to their families. Many of the fine young men who did this afterwards became 


\section{FIGHTING THE INSECTS}

prominent in the professions. Others who began in this way have eventually come back to Washington as Senators or as members of the House of Representatives.

When the tall bicycle first came into use it was rather expensive. I think that an old so-called Columbia wheel cost one hundred and fifty dollars-perhaps more. Living was very cheap, and these boys who were drawing one hundred to one hundred and fifty dollars a month were able to buy wheels. On the whole, it was a well-educated and rather financially independent set of young men who started the club, and it stayed in existence for many years. Friendships were formed that lasted through life. There were long runs and race meetings, and there was a club house and congenial club life and college songs and dances. In fact, it opened up a side of life quite new to a young fellow who had come from an outside environment. It must be confessed that during the years prior to 1886 this club, with its many activities, its visits from the clubs of other cities and its visits to other cities, filled more of my mind than it should have done. But on the other hand it was broadening to a certain point, and it kept us all out of doors much of the time, so on the whole it made us healthier and better men.

It is difficult for people nowadays to realize the activities of the old tall bicycle clubs. The men of my age who could afford it nearly all belonged to one or another of these organizations. There was a national group, and it published its own journal, The American Wheelman, which, by the way, was founded and edited by S. S. McClure, who became so prominent in later years as the head of a publishing house, the founder of a magazine, and later as a writer. In fact, many men of later prominence belonged to those old clubs. I remember, for example, a visit we once had from the Germantown (Pennsylvania) club. One of 


\section{THE STORY OF AN ENTOMOLOGIST}

its members interested us greatly by making some impromptu and very clever pencil sketches. His name was Joseph J. Pennell. This man reached exceptional fame, but it is also true that there were many others who reached high rank in many lines of thought and action.

As it happened, I presided rather recently at a big dinner celebrating the fiftieth anniversary of the founding of the Capitol Club. It was attended by seventy or eighty gray-haired veterans, and I had much sly pleasure in complimenting patronizingly the after-dinner speech of a retired Major General of the U. S. Army, who, as a long-legged boy, had ridden a sixty-inch wheel on many of our runs.

I could tell many stories about these young men, but I can spend very little time on these side matters. I should, however, mention one forgotten genius who, in fact, did not live long enough to become well known. His name was L. Warren Seely. He had never been to college, and, as is so often the case with men so placed, he greatly exaggerated the value of a college education. This man had an extremely bright mind and wrote with great ability and charm. He was a patent lawyer and his occupation irked him. One especial instance of his cleverness sticks in my mind. We were calling together one night on some girls. It was in the days of autograph albums, and one of the girls said, "Oh, Mr. Seely, you are so clever, won't you write something in my album?" And Seely sat down and spontaneously wrote the following lines:

When old Ulysses on his path of duty

Close by the Sirens' Islands sailed his ships,

He saw there forms of more than mortal beauty,

And heard celestial music from their lips.

'Tis said he sailed away, but I'm afraid

Had you been one of them he must have stayed. 


\section{FIGHTING THE INSECTS}

I begged Seely to send this to Life. He protested, but finally did so, and it was published. He received a check, I think, for two dollars, which he kept as a souvenir and never cashed.

But enough about the Capitol Bicycle Club and about the tall bicycle. That extraordinary machine was succeeded, after the invention of the chain wheel, by the low-wheeled machines, and for me, at least, the spirit of adventure in whecling was lost. But at the same time the tall bicycle and the bicycle organizations constituted an early and very strong impetus to the Good Roads Movement which, through the much later invention of the automobile, has revolutionized road travel in most countries. Contrast in your mind, if you can, the roads of today and those of fifty years ago!

But time did not hang heavily on my hands outside of office hours, even in the days before the bicycle. Mac Borden and I were very fond of whist, and had played against each other in interfraternity tournaments at Cornell. President Hayes was in the White House, and one of his sons, Rutherford B. Hayes, Jr., had also been at Cornell with us and had played for his fraternity in the same tournaments. Young Hayes looked us up during the first winter, and we played whist at the White House at least once a week. We saw little of the President, but Mrs. Hayes was a charming woman, who treated us quite as members of the family and was utterly devoid of pretense.

Those were rather primitive days in Washington. The downtown parts of the city had already been paved with asphalt, and the early marked improvements carried out under Boss Shepard had been finished, but the northwest quarter had not been developed, although the tendency was in that direction. Pennsylvania Avenue and Seventh Street out as far as K Street were the only important business thoroughfares, although shops were encroach- 


\section{THE STORY OF AN ENTOMOLOGIST}

ing on F Street. It seems strange to think of the present busy F Street between Seventh and Fourteenth as still bordered in part by residences. The First Congregational Church at the corner of Tenth and $G$ had been built, and a fine organ had been installed. We often went there Sundays, to hear Professor Bischoff, the famous blind organist, and also to listen to the excellent sermons preached by the Reverend Doctor Rankin.

Carl Schurz was then Secretary of the Interior, and people spoke of his culture and of his ability as a pianist.

It is really surprising that a man can live in Washington as I have for more than fifty years and yet see very little of Congress, even though connected with a government department. That may be due to my individual tastes. Politics has never interested me as much as it should a good American citizen, and the professional politician has not appealed to me as an agreeable companion. In my boyhood, a professional politician was not an agreeable person, even though he tried to be all things to all men. Of late years the general average is higher, and many admirable men have gone into politics and pushed to the front.

When I first came to Washington I was naturally interested in Congress as one of the sights of the city, and several times went to evening sessions and, from the galleries, watched the men on the floors of both houses. In the House at that time were several men of mark, notably James G. Blaine and L. Q. C. Lamar, the leaders of the two sides of the chamber. I liked Lamar, although he was a new type to me, as he was typically Southern. Blaine I did not like from the start. On several occasions I happened to see him acting in what I considered to be a brutally discourteous manner, and that was probably the beginning of an antipathy which continued until the time of his death. A man in the House at that time whom I admired very much was the Honorable J. D. Cox. 


\section{FIGHTING THE INSECTS}

I also visited the Senate on several occasions (Blaine and Lamar shortly went from the House to the Senate). In the Senate I was interested in John A. Logan and in Senator Vorhees, who was then called the "Tall Sycamore of the Wabash," and who was an orator of the florid type. The man who impressed me most was George F. Edmunds of Vermont, who seemed to have a very clear intellect and a tremendous grasp of all the subjects that came up. I listened with intentness to everything that he said. His adroitness in debate was extraordinary, and, as everyone knows, he was the author of several laws of great importance. It is curious to recollect that he impressed me at that time as a venerable old man, already bald-headed, and with a nearly white beard, but I learned many years later that he was still living (in Pasadena, California), and in I9I8 my friend, Dr. J. H. McBride, of that city, told me that Edmunds was his neighbor and that he frequently called on him. He further said that at that time he was intellectually as much alive as ever, although it was forty years earlier when I had thought of him as a venerable old man.

Both House and Senate in those days were largely composed of veterans of the Civil War. From a cultural standpoint, they did not rank high, but, though I was disappointed in the general character of the men I saw on the floor of the House and whom I occasionally met in the boarding-houses and at the hotels, I reflected that each was a representative selected from a hundred thousand or more American citizens, and that there must be something in his character that brought him out of the mass. The country at that time worshipped war heroes, and in a democracy where there is universal suffrage the demagogue naturally has a very good chance.

During this early period it happened that the alumni of Cornell University who were living in Washington formed an 


\section{THE STORY OF AN ENTOMOLOGIST}

association, and I was one of the early presidents. Before our first dinner I went through the Congressional Directory in order to get an idea as to the number of men in Congress who were college-bred. It was surprisingly small. If I am not mistaken, there were not a dozen men in either house at that time who had ever seen the inside of a college. But, of course, I remembered that many of these men were fighting in the Civil War during the years that some of them, at least, would have been at college. I may state here incidentally that many years afterwards-I think it was in 1913 or 1914-I went again over the Congressional Directory with this point in mind and found that then the proportion of college-bred men in Congress was very much higher. The majority-a considerable majority-of the men then serving had received some kind of college education, and men from the principal universities of the country were very much in evidence.

It must have been about I88I, when the House of Representatives was discussing the combining of the Wheeler and the Hayden Surveys into the United States Geological Survey, that E. C. Manners, a charming and sophisticated Columbia graduate, who was private secretary to Clarence King (chief of the Wheeler Survey), asked me to go to the Capitol with him one night to listen to the debate.

I recall only one incident, but it amused me greatly. A youngish member of Congress from Colorado (I have forgotten his name) was discussing the bill in opposition. As I remember it, he said substantially this:

"Upon whose advice are we supposed to take this action? On that of the so-called National Academy of Sciences? What is this National Academy? A scientific organization is usually judged by the character of its publications. Now, what has this Academy published? So far as Mr. Spoffard, the Librarian of Congress, 


\section{FIGHTING THE INSECTS}

can tell me, it has published (at the Government Printing Officeat Government expense!) only a short series of biographic accounts of deceased members. Now, I put it to you, gentlemen, if this futile and pointless body of mutual flatterers attempts to interfere with the actions of the law-makers of this great people, would it not have been far better for the United States if the number of laudatory obituaries had been far greater than it is?"

As a much later member of the Academy, and as a writer of one of these biographical accounts (that of Stephen A. Forbes), I am now in a position to appreciate that speech even better than at that time.

The mention of E. C. Manners reminds me that once, when we were walking along a Washington street, I made a quotation from something or other, and he remarked in his supercilious way, "It's astonishing how many people there are with just enough knowledge to misquote!" This remark rankled until later I discovered that his statement itself was a misquotation!

And, speaking of the Academy of Sciences, I always recall a remark made by Professor J. McKecn Cattell, referring to the springtime beauty of Washington: "The best reason known to me for the existence of the National Academy of Sciences is that it meets in Washington during the third week in April each year!" Nevertheless, we are all proud of the Academy and its beautiful building and its vigorous and useful child-the National Research Council. It is not so old as the Royal Society of England nor as the Académie des Sciences of France, nor as the Academia dei Lincei of Rome, but it ranks as one of the foremost National Academies of Science in the world.

And as for the United States Geological Survey, it has justified its existence, and the bill which the member for Colorado was opposing has proved its value a thousand times. 


\section{THE STORY OF AN ENTOMOLOGIST}

One more Congressional incident apropos to this general subject. Fifty years ago the final reading of the Appropriations Bill for the Department of the Interior was before the House, and I happened to be in the Visitors' Gallery. The Honorable J. D. Cox of Ohio, Chairman of the Appropriations Committee (and himself a naturalist), had the bill in charge and was making slight verbal corrections and corrections in punctuation, to which the members were perfunctorily and sleepily agreeing. Coming to the portion on the Hayden Survey of the Territories, and to the paragraph relating to permission to publish, he suggested the addition of the words "and the allied sciences" to the words "on geology," and the House assented without awakening. This enabled the publication by the gevernment of many important monographs which would have seemed trivial and possibly useless to the then average congressional intelligence.

Since those days, fortunately, Congress has become better educated in such matters, and here and there in the House and in the Senate are to be found men with a keen appreciation of the value of practically all sorts of scientific work-many, in fact, who realize that research work without an immediate practical end is quite worth while and worthy of even government support.

But my initial interest in Congress didn't last. Holding an assistant's position in a small department, I had nothing to do with the appropriations which were then handled entirely for our department by the Commissioner of Agriculture. In fact, the Department did not develop to the point where the Commissioner, or later the Secretary, needed any assistance before the Agricultural Committee until after I became Chief of the Bureau in 1894. Before that time my chief, Professor Riley, was always worrying about appropriations, and, without the consent of his superior officer, was constantly pulling wires of different kinds 


\section{FIGHTING THE INSEC'TS}

to get more money. I remember that once in the I880's he was out of town when the Appropriation Bill was about to be reported and that he telegraphed me to call on Congressman Hatch of Missouri (the author of the Hatch Act, under which all the State Experiment Stations of the country were founded), who was then Chairman of the Agricultural Committee of the House, and urge him to use his influence for a certain small appropriation. I found Congressman Hatch in his rooms on the second story of a building on F Street, I think between Tenth and Eleventh, where he was living with his family. He came out into the room that was used as a parlor to see me-a bluff, democratic, Western sort of man-and told me very plainly that he had no opinion of my chief and that he would better stay in Washington and attend to his business than go to Florida on a junket.

On a later occasion, when Professor Riley was in Europe, the appropriation for entomological work seemed to be in danger. It happened that Dr. C. Hart Merriam had just come to Washington to undertake work on the food habits of native birds as a branch of the division of entomology. He did not like Riley, but he was a great friend of mine and told me that he would go with me to his cousin, Warner Miller, who was then U. S. Senator from New York. We went together in the evening to call on Senator Miller in a beautiful house on $\mathrm{K}$ Street near Fourteenth. I found the Senator a charming and well-educated gentleman, who told me that, while he did not approve of Professor Riley, he knew that the work was important, and that he would do what he could to put the appropriation through. He succeeded. I think that those were the only two bits of lobbying I ever tried to do.

While we are on the subject of Congress and Congressmen, 


\section{THE STORY OF AN ENTOMOLOGIST}

I may as well go further, although it takes the story out of its chronological order.

Shortly after I became Chief of the Service, Congressman Wadsworth of New York (father of the later Senator Wadsworth of New York) was Chairman of the Agricultural Committee of the House. He conceived the idea that it was his duty to know more about the workings of the Department than had been the custom with chairmen of that special committee. One day, therefore, he appeared at the Department with four or five other members of the committee (one of whom was John Sharp Williams, later U. S. Senator from Mississippi, a great speaker and one of the personalities of the Senate), and went through all the bureaus, going into the insectary, looking at the insect breeding in the cages and examining all the details of the work. The next year he had the chiefs of the different branches appear one after another before the committee to explain fully what they were trying to do and why they wanted the amounts of money that were estimated. From that year, which must have been about 1896 , such hearings have been held at the beginning of every session of Congress.

These hearings were very trying to the bureau chiefs, partly on account of the ignorance of many members of the committee -an ignorance, in most cases, combined with egotism and pride of place-and partly on account of the fact that they put the Bureau Chief in the position of a defendant at the bar, apparently taking the stand (and many of the committee men were country lawyers) that there was some graft going on and that it was their duty to expose it. Doubtless this attitude on the part of members, which the Bureau Chiefs used to resent, was largely a matter of imagination, and really as time went on it grew less every year. It became obvious, in fact, that many of the members of the committee were very earnest in their desire to do what 


\section{FIGHTING THE INSECTS}

was right by the country and by the department and to inform themselves as accurately as possible concerning what was going on. Nevertheless, the task continued to be an onerous one for the Bureau Chief, and he found himself in a distressing position when he was not accurately informed upon every subject that came up and not able to answer cleverly and satisfactorily every question that was asked him, whether pertinent or not. I have myself wriggled internally under such conditions, and, with a sort of malicious joy, have watched other Bureau Chiefs wriggling when I happened in toward the end of one hearing or stayed on into the beginning of another.

The general effect of these hearings, however, is very good. Twelve or fifteen years ago, when I happened to be in the Secretary of Agriculture's antechamber, ex-Congressman James Wadsworth entered with a tall, smooth-faced young man. $\mathrm{He}$ greeted me with his usual cordiality and introduced the young man with great pride as his son, the newly elected Senator from New York. The young Senator said that he knew me well by reputation and remembered with the greatest interest that once years ago, when he was on a vacation from Yale College and had come down to visit his father, he went with him to one of these meetings of the Committee on Agriculture. He said that he listened to the statements by the Bureau Chiefs with the most intense interest, and that he considered the general education he gained in that way was rather better than anything he got at Yale.

One funny incident that happened while Mr. Wadsworth was Chairman of the Committee was in the early part of the century, when the first application was made to Congress for a considerable appropriation to fight the Cotton Boll Weevil. I had had a large papier-mâché model made of the weevil. It was about two feet long, and I had it sent up to the Committee room in 


\section{THE STORY OF AN ENTOMOLOGIST}

a dry goods box. When Mr. Wadsworth said, "We will now hear from Dr. Howard about this appropriation for the Cotton Boll Weevil," I took the cover from the box, lifted out the model and put it on the table in front of me. Captain Lamb of Virginia (then a member and afterwards chairman of the Committee) turned with amazement to Congressman Burleson of Texas (later Postmaster General), and said, "My God, Burleson, is it as big as that?"

Mr. Wadsworth, by the way, was a Congressman of the very highest type. He afterwards had trouble with President Roosevelt, and there was a newspaper spat between them that was very warm.

During the early days of the Cotton Boll Weevil investigation I had rather disagreeable experiences with several of the Southern members of Congress who wanted the headquarters for the investigation located in their districts. In fact, as the service was extended and other large projects were taken up, I had other disagreeable experiences of this kind, not only in the location of stations, but in moving the stations from one point to another when it became necessary.

I should explain that it became the policy of the Bureau rather early to carry the laboratory to the problem rather than the problem to the laboratory. Having arrived at a satisfactory agreement with the state authorities, a proper point in the field was picked by the expert in charge of the investigation, a house or a small farm or both would be rented at some strategic point, assistants would be sent there, and supplies would be bought. And then, when it seemed desirable to change the location, this place was given up and another one found. But the inhabitants of a country community do not wish to lose these stations, and they naturally appeal to their members of Congress. Many a time I have had a Congressman come and argue the question 


\section{FIGHTING THE INSECTS}

with me and then go to appeal from me to the Secretary of Agriculture. In the case of some large stations he might even go to the President of the United States and appeal from the Secretary of Agriculture. I believe that such men have always been referred back to the Secretary, and by him back to me, and of course I relied entirely on the judgment of my field assistants. I actually had one Congressman tell me once at my desk, with his voice trembling, that his reëlection depended upon his success in retaining a certain station for a certain district. Surely the Congressman has a hard time!

I think I have already mentioned the fact that when I first came to Washington political influence was paramount and that almost every clerk had his backer in Congress and held his place so long as he held the good opinion of his or her special Congressman. This was before the days of the Civil Service Commission. Conditions were about as bad as they possibly could be. I am sure that Congressmen themselves felt a decided sense of relief when the first Civil Service Commission took office since they could tell all office-seekers that their Congressmen could be of no help and they must pass the examinations. I have heard that the idea "to the victor belong the spoils" still holds with certain of the states, and that office-holders are not only political partisans but are contributors to campaign funds. I have already stated that the first year I was in Washington I was asked to contribute one month's salary to the campaign fund. Imagine a man with a family on a salary of one hundred dollars a month obliged to meet a demand like that!

Probably one reason why I have seen so little of Congressmen is because I have spent so much of my spare time at the Cosmos Club, and there you very seldom see a Congressman. In the early days of the Club there was only one member from the Hill, and he was Congressman Everett from Massachusetts, an old school- 


\section{THE STORY OF AN ENTOMOLOGIST}

master, and I think at one time a Harvard professor-a retiring man of much culture and rather out of place in Congress, though quite at home at the Club. Later William E. Chandler, a brilliant man who had been United States Senator and a member of the Cabinet, was proposed for membership but was blackballed by some of the Survey men on the ground that he had successfully opposed one of their appropriations when he was in the Senate. Of course it was a disgraceful thing to do and was a blot on the fair record of the Club. Senator Chandler was a brilliant man and one of the most interesting individuals I have ever met. He used to come to the Club very often as a visitor before this incident, and it was a liberal education to hear him talk to a group of men.

Later, as the Club became rather broader, blackballing by members was done away with, and a number of Congressmen passed the Committee-William Kent of California, later a member of the Tariff Board; John J. Fitzgerald of Brooklyn, at that time Chairman of the Appropriations Committee; Townsend of New Jersey, an old newspaper man and author of the "Chimmie Fadden" stories; Senator Owen of Oklahoma, a man of very broad culture; Small of North Carolina, a quiet, retiring individual but a delightful man when you drew him out; Redfield of Brooklyn, later Secretary of Commerce, a wonderfully able man of commercial training and one of the most eloquent speakers I ever heard; Dr. H. W. Temple of Pennsylvania, a cultured man who had been a college professor; and perhaps a dozen or more others who need not be mentioned.

Since the William E. Chandler incident, I believe that there have been no unpleasantnesses connected with such memberships. I remember to have heard, however, that Uncle Joe Cannon, who was a frequent visitor at the Club, once said in a speech, "I know of a certain club in Washington where more schemes 


\section{FIGHTING THE INSECTS}

are hatched against the United States Treasury than in any other one place."

The thirteen years of $188 \mathrm{I}$ to $\mathrm{I} 894$, filling the time between Comstock's departure and Riley's resignation as Chief of the Service, must not be dismissed summarily, since it was a time of achievement as well as of development and education. In the last chapter I have mentioned what was perhaps the crowning achievement of Riley's second régime, namely the introduction of the Australian Ladybird, which really started the important line of natural control work. But there were other rather big things.

A notable one, now almost forgotten, was the solving of the problem of the hop plant-louse. Although it was only one of several important studies, it had interesting and unique features. This was long before the sad days of Prohibition. The beermanufacturing industry was very important. Hops were grown extensively in many regions, although the landscape was not dotted with hop yards as, for example, are certain regions in Kent and in the country south of Budapest. The largest centers of hop production in the States were probably in portions of New York, Wisconsin and Washington. It had been known in England that the worst insect pest of the hop crop, namely the hop plant-louse, occurred both on the hop and on the plum. But its rather extraordinary life history had not been worked out. Riley started an investigation which was successfully carried on by his assistants to a rather brilliant conclusion. The field work was done at Richfield Springs, New York, practically wholly by Theodor Pergande, who spent the better part of 1886 at that point. Professor Riley was in Europe at the time, and I visited the field in the summer of 1886 to check up Pergande's observations. W. B. Allwood was there, engaged largely on the subject 


\section{THE STORY OF AN ENTOMOLOGIST}

of sprays and spraying machinery. But the result of Pergande's work completely negatived the necessity of sprays on the hop crop. And this was the first experience that started in my mind the idea that while sprays are of temporary value, that value lasts only until the entomologist is able by his life history studies to find something cheaper and easier and more natural, which will bring about a more perfect control. In other words, while we welcome the activity of the spray machine manufacturers, at least temporarily, are we really not trying to put them out of business?

The result of all the work here was to show that the plum is the necessary secondary host of the plant-louse. The plum, of course, is a perennial, while the hop vine is an annual. The winter eggs of the plant-louse are laid upon the plum in the autumn. In the spring they hatch, and there comes forth a generation of wingless virgin females but no males. These females are called the stem mothers. They give birth to living young that feed upon the sap of the plum leaves. Growth is very rapid and there soon develops a generation of virgin females that are winged. By that time the hop crop has been planted, and all of this new winged generation fly to the hop (deserting the plum) and give birth parthenogenetically to successive generations of wingless females, all feeding upon the hop leaves and frequently blighting the crop. Then, about the time of hop-picking, a winged generation (all females) comes forth and flies back to the plum trees. From these there comes a generation composed of both males and females, and from this generation comes the winter egg on the plum. What an extraordinary thing! The removal of all plum trees near the hop yard or the destruction of the lice on the plum in the spring by means of sprays perhaps will free the ensuing hop yard from all possible danger from this source. 
FIGHTING THE INSECTS

Careful studies by later students of plant-lice have turned up many life histories as interesting as this, showing a relation between annual and perennial plants as to their plant-louse populations.

While this study showed a comparatively easy method of control, I think that perhaps it was this close and accurate investigation of plant-louse methods of life (although already known in a general way) that really started me thinking about insect possibilities. And I was hardly astonished when Professor Glen W. Herrick brought out his extraordinary calculation that the ponderable mass of the offspring of a single cabbage aphis in five months' time in Central New York would, without accident or control, exceed the ponderable mass of all humanity on the globe by at least five times. 


\section{Chapter IV}

L

IFE in Washington at that early time was not expensive, and it seems to me that the government clerks got along very well, in fact, quite as well as they do today, on what seem now pitifully small salaries. The one hundred dollars a month that was all I got for the first few years was ample. In fact, I put forty dollars of it in the savings bank each month for the first year. The room that Mac Borden and I lived in cost us ten dollars a month each, and there were several restaurants that gave us very good meals for twenty-five cents each. I remember especially one called the Holly Tree Inn, on Ninth Street just below F. It was kept by a dear lady named Mrs. La Fetra, whose husband was a pleasant bearded man, a clerk in the Post Office Department. They had a little boy who, I think, has grown up to be some distinguished person. Another restaurant that I remember very well was Fred Evans', on F Street between Ninth and Tenth. It seems to me that he raised his price to thirty-five cents a meal, and that it was considered to be rather a spree to dine there.

Living for us was very simple, you see, and the married clerks got along very well, too. A good colored maid-of-all-work could be had for ten dollars a month or even less, and some of them 


\section{FIGHTING THE INSECTS}

were fine. A very fair six-room house could be rented for twentyfive dollars a month, and I never heard any of my married friends in the departments complain seriously about financial difficulties.

All salaries under the government were small. My friends were mainly among the young fellows recently graduated from college, and most of them were connected with the more or less scientific branches, such as the Smithsonian, the National Museum, the Geological and Topographical Surveys, the Coast and Geodetic Survey, or the Topographic Division of the Post Office Department. Some of them were in the Patent Office and the Land Office. Then, too, there were some who were studying law or medicine, who held temporarily any clerkships they could get. It was a simple, happy life.

When a man married he needed a little more money, and so he began to reach out and do different things. Among others I felt this necessity. When I married in I 886 my salary was raised to eighteen hundred dollars, which was not bad when you consider that the Chief of the Service got only twenty-five hundred dollars. But opportunities for making outside sums began to open up. Professor Riley, although his salary was so small, had married into a family of means and had no financial worries. He was, however, in many ways the foremost light of his kind in the country, and was occasionally asked to write articles for journals of one kind or another.

I remember for example that the Youths' Companion asked him to do a series of illustrated articles on household insects. He got me to write them for him, signed them and sent them in. They were published, and he gave me half the money, which I was very glad to get. This seemed all right to me at the time, since his prominent name was surely worth that much to the journal. 


\section{THE STORY OF AN ENTOMOLOGIST}

And now I think I must say something about the Century Dictionary. About 1885 , when the Century Company was planning its great dictionary, they appointed Dr. Elliot Coues as Zoölogical Editor. He was one of the foremost men in the public eye at that time. He looked about for illustrations, and was recommended to use the beautiful woodcuts belonging to Professor Riley, which the latter had made to illustrate his Missouri reports. He had been wise enough to have them done at his own expense, so that he still owned the original blocks. The Century Company paid him a large price for electrotypes of these blocks, and he sold them with the proviso that he should write the definitions of the words so illustrated. During the winter of $1885-86$ he worked a little at these definitions with the assistance of E. A. Schwarz and myself, and when he went to Paris as the representative of the Department of Agriculture at the French Exposition of that year he told me to go ahead and finish up the definitions for him and to help Dr. Coues out in any way I could. It was evidently his understanding that he was to remain the entomological contributor of the dictionary, and that I was to receive only perfunctory acknowledgment if any.

I called on Dr. Coues shortly after Riley's departure, and found him in Dr. Theodore Gill's room in one of the towers of the Smithsonian Institution. I turned over to him some definitions of words illustrated by the Riley cuts, but he stopped me as I was going out of the door and asked me whether I had written them myself or whether Riley had. I told him that I had done them after Riley's departure, and he remarked that evidently I was just the man he was looking for. He told me he knew Riley had no knowledge of many things that a dictionary man should know, and he asked me if I would take over the entomology on my own account under him. I said that I would, and I did all of the entomological definitions from that time on. 


\section{FIGHTING THE INSECTS}

The business manager of the dictionary at that time was Dr. Benjamin E. Smith. He had a cousin, Herbert H. Smith, who was a great collector of insects and had made several expeditions to South America and the West Indies, where he had got a vast amount of material, some of which is now at Cornell University and more at the Carnegie Museum in Pittsburgh. He also made afterwards the collections on St. Vincent and Granada for the British Association for the Advancement of Science. The bulk of that material is now in the British Museum of Natural History. It should be noted here that the Chalcidide of this St. Vincent collection were afterwards monographed by Dr. W. H. Ashmead and myself, that the Granada Chalcididie were turned over to me, and that at a much later date I published a paper on them in one of the English Transactions.

Owing to this relationship between Benjamin E. Smith and Herbert H. Smith, Herbert had been employed at some entomological definitions before I took hold. These occur only in the first part of the original twenty-six parts of the dictionary.

In talking over the general style of the definitions, Dr. Coues made this extraordinary remark to me: "You need not confine yourself to words actually in existence, but if you think of any useful new word put it in." And this remark suggests a digression. Some years later, Professor E. B. Poulton, arriving in this country from Oxford during one of Riley's frequent absences from the United States, said to me, "By the way, Howard, Professor Murray, while engaged in his work upon the great Oxford Dictionary, has found certain words in the Century Dictionary which he is unable to trace, and, knowing that I was coming to this country, he wrote me a letter in which he said that these words must have been invented by some Yankee schoolmaster who had a penchant for invention and had seized the chance 'to inflict new atrocities upon the English language." " And then 


\section{THE STORY OF AN ENTOMOLOGIST}

Poulton showed me the list. He was surprised when I told him that I was the man who wrote the definitions, but he was still more surprised when, after looking at the list of words, I told him that I had found them all in Kirby and Spence, a classical English work published about I834. I wrote an explanation to Professor Murray, and received a courteous reply, but he evidently never knew that I had seen his letter to Poulton.

I think I will allow myself to step aside from the dictionary for a moment. When I first came to Washington, in the fall of $1878, \mathrm{I}$ brought with me, among other letters of introduction, one to Dr. Coues from Burt G. Wilder. I called on him and was received pleasantly. After chatting a few moments, I told him that I was assisting Riley, and then left. As it happened, while working with Wilder and Gage during my post-graduate year at Cornell, I had become much interested in the general subject of vestigial structures, inspired by one I had found while dissecting a still-born infant. I had looked up the general subject in the University Library and had started a small card catalogue of such structures. I had, I think, twenty or thirty references. When it appeared during the spring of 1879 that Riley was likely to use me quite as much as a clerk as a laboratory assistant, I thought about going back into medicine, and called on Dr. Coues again to see if he could give me further references to this anatomical line of work. I found him in a bad humor, in an office across Pennsylvania Avenue-on Tenth Street, I think. He received me brusquely and I explained my errand. "Oh, why? I thought you were an entomologist and not an anatomist." I held out my twenty or thirty cards, and he said, "Humph, do you call that a bibliography? Look here"-and he pointed to an array of card cases-" "here are twenty thousand cards, forming my bibliography of North American birds." I was very much abashed 


\section{FIGHTING THE INSECTS}

and left as speedily as possible. I had not seen him from that day until the Century Dictionary call.

I worked on the dictionary at odd times until it was completed, and my relations with Coues were extremely pleasant. He was a very extraordinary and very eccentric man. After he married his second wife, he had a beautiful furnished house on N Street, between Seventeenth and Eighteenth, and no matter how late in the evening I called I found him at work in his study, with a coffee-pot and with innumerable cigarette butts scattered about, but always ready for a chat. He pretended to be interested in Spiritualism and was a great friend of Madame Blavatsky. Before he died he told me that his Spiritualism was only a pose, and that he was really slyly investigating Spiritualism and Theosophy,

As the dictionary approached its close, he went through Scudder's "Nomenclator Zoölogicus," and discovered that the last word was entomological. In great glee he said to me, "You are going to have the honor to define the last word in the English language." I asked him what it was and he told me that it was Zyxomma. It would be difficult to follow that if one were to preserve alphabetic order. I told him that it was the name of a very obscure genus that had no business in the dictionary, and he said that that did not make any difference. "For the honor of Zoölogy we must have the last word." Curiously enough, two years later, Captain Prince, the librarian of the Patent Office, told me one night that his son had come home from school and told him that his teacher had instructed the class that they must bring in next day the definition of the last word in the English language. The boy asked his father what that word was. The Captain told me that it gave him great joy to tell the boy that he knew the word and that he knew the man who wrote the definition. The boy, undoubtedly, as boys will, told the others the next day in a boy's boasting way that his father knew the man 


\section{THE STORY OF AN ENTOMOLOGIST}

who wrote the definition of the last word in the English language. So in at least one very small way Coues was justified.

Several amusing things happened in the course of the dictionary work. For example, one of the resonant words selected by Coues and sent over to me was Dundubia. It was easy of definition, but when it came to its etymology I was stumped. I searched for all possible Greek and Latin origins, and then wrote on the margin, under the head of Etymology, "Try Sanskrit," in much the same way that one would say, "It's all Greek to me."

Some weeks afterwards Benjamin E. Smith wrote me, "Professor Whitney [a great philologist of Yale, who was the Philological Editor of the dictionary] decides that you are right in deriving this word from the Sanskrit. It comes from the Sanskrit Dundub, which means a drum." As Dundubia is a genus of Cicadas-insects that make a peculiar drumming noise in the trees-the applicability of the name was obvious. I afterwards found out that the French authors, Amayot and Serville, who wrote many papers on the insects of this group, had lived in India, knew many Sanskrit words, and had used several of them in their nomenclature. I hope that Professor Whitney finally died in the full belief that I was a Sanskrit scholar.

The whole work was extremely interesting and had a high educational value. Things that I learned then have been of service to me in many ways. Then, too, the extra money was a great help. It brought me in, say, from twenty to fifty dollars a month for a long time. Years later I helped in the revision, made some changes, introduced a good many new words, and made some more money. It is a very good thing to have been connected with a dictionary of this high character and to have had dealings with such courteous and generous people as there were in the New York office.

Later, on request, I contributed several articles to the Century 


\section{FIGHTING THE INSECTS}

Magazine, and still later the Company published two of my books.

After this beginning with the Century Dictionary, I was able to get enough outside work to keep my family going. I worked on the Standard Dictionary, and also wrote many articles for the New International Encyclopedia and did a lot of other work of that general character.

And then there were not infrequent magazine articles and lectures, and of course the Insect Book and the Mosquito Book in I90I and the House Fly Disease Carrier in I9II.

I mentioned lectures in the last paragraph. Like so many young men, I was especially self-conscious, in fact, awkwardly so, before any kind of an audience, although, judging from some of the men I have known, mine was not an extreme care. I had always dreaded anything of the sort in college and could not hold my own in a public debate. As time went on in Washington, I read papers before scientific societies there and elsewhere, but I had never dared attempt a lecture without manuscript. My knees trembled at the very thought.

It must have been in the very early spring of 1898 that I received a letter from Dr. J. M. Taylor, the president of Vassar College. Dr. Taylor was not only a very charming man, but he was a very wise one. He had thought out a plan that I think was unique for a college president. He made up his mind that the students at Vassar did not know enough about the intimate details of their government, and decided that he would go to Washington and stay, if possible, at the Cosmos Club. There he felt sure he would meet men who were doing big things for the government in a quiet way, and he thought he could induce some of them to come up to Poughkeepsie and tell the girls about it. So he came down, and I put him up at the Club and introduced him to just the men he expected to meet. 


\section{THE STORY OF AN ENTOMOLOGIST}

The result was that I was one of the men invited to go to Vassar the next year. I knew that it was a chance that I should not avoid, and that I must learn to talk to an audience without manuscript. So I thought that I would begin in a gradual way at Poughkeepsie. I prepared a manuscript that would take about a half-hour to read and then planned to use the remaining halfhour in talking with lantern slides. When I reached the college it was about dinner time, and I dined with Dr. Taylor and some of the professors at a table in the big college dining-room. I asked the President in an offhand way what kind of an audience I could expect, and my fears were not at all appeased by his reply, which was to the effect that it was either the best audience in the world or the worst-that it all depended on whether you caught their interest at the start.

Then we went into the big chapel, and I was introduced to the amazingly attractive roomful of girls. I placed my manuscript on the reading desk-a temporary sort of thing. It was apparently an old music stand that screwed up somewhere near its middle. I made a few opening remarks, leaning my elbow on the tricky pedestal, and as I did so, the darned old thing gave way and the manuscript fluttered all over the place. Here accidentally was an incident sure to attract the interest of those girls, and how they did laugh! I looked at the manuscript in sheer despair and remarked that, after all, I imagined that was the best place for it. I went on with the lecture, and the audience was very appreciative. The best of it was that I gained great confidence in myself and have never used a manuscript in any public talk since. I have always felt very kindly toward Vassar, and many years later my youngest daughter graduated there. She was not born at the time of this incident.

After that chances to give lectures multiplied, and during the next thirty or more years I gave a large number, some of them 


\section{FIGHTING THE INSECTS}

at universities and others before all sorts of organizations, and I have grown to enjoy it. For many years I have not felt a trace of embarrassment before an audience. This lecturing, however, has not been frequent enough to interfere with my official work. In fact, it has helped very much to make it better known, and incidentally it has helped the family in its yearly expenses-not much, but enough so that it has counted.

By this time I had become interested in the carriage of disease by insects, and about the beginning of the century I gave many talks before medical societies, city improvement associations and health organizations about this important subject.

Among the most interesting and surely the most remunerative of the lectures I gave were those before the Lowell Institute in Boston in the early spring of I902. I had heard much of the Lowell Institute and had read many of the lectures given there by famous men and was therefore immensely flattered and delighted when dear old Dr. William T. Sedgwick, the Curator of the Institute, wrote me with Mr. Lowell's consent and asked me to give eight lectures on Economic Entomology. I don't know how those lectures are carried on nowadays-possibly in much the same way-but in those days they were held in one of the old buildings of the Massachusetts Institute of Technology, on Berkeley Street. The audience had to be seated at eight o'clock, for the doors were then locked and the lecture began. At nine o'clock the doors were unlocked, and people could leave whether the lecture was finished or not. I suppose that the time tables of suburban trains accounted for this regulation, but it took a mighty interesting lecture to keep people there after nine.

My lectures were illustrated by very good lantern slides, and in the eight I covered all of the field of Economic Entomology that was known at that time. I remember that the first one was on the subject of the carriage of disease by insects. Mr. and 


\section{THE STORY OF AN ENTOMOLOGIST}

Mrs. Lowell were seated immediately in front of me, and with their charming courtesy they managed to appear interested until the close. I was a little annoyed by the slowness of the lantern operator, but Sedgwick explained to me that he was an elderly negro who had been running the lantern for years, and that he thought he knew how to do it better than the lecturer did. I was a little afraid of the people in my audience as they looked so preternaturally intelligent; and I was very serious during the first seven lectures. Just before entering the hall to give the last lecture, however, Sedgwick gave me Mr. Lowell's check for twelve hundred dollars, and with this in my pocket I felt exhilarated and able to take liberties even with a Lowell Institute audience. To my surprise, they liked it and seemed to enjoy my stories so much that I told many of them. Even the Boston Transcript spoke next day with especial favor of that last lecture, informal as it was.

In mentioning the Lowell Institute audience I am reminded of an incident. I spent the five weeks during this lecture course at the St. Botolph Club, and on one of the off nights after dinner, in one of the reading rooms, I heard two men, sitting not far from me, discussing some subject rather vigorously. One of them said, "I tell you, my friend, the world is full of sham, and I think that Boston's pretense to intellectuality is large part sham. Look at lots of the things you see around us here. Take the Lowell Institute lectures, for example. A lot of people go there because they think they ought to. They listen to a whole lot of uninteresting and sometimes absurd statements and look owlishly wise, and then go home and say to themselves, "What superior people we are." "

I could not help overhearing the man and listened with a very amused interest. I caught the eye of the other one, who hap- 


\section{FIGHTING THE INSECTS}

pened to be Dr. Woods of the Harvard Medical College, and he called me over.

"Dr. Howard," he said, "I want you to know Mr. Wilton Lockwood, one of our foremost artists. Mr. Lockwood, this is Dr. Howard of Washington, who is now giving a course of lectures before the Lowell Institute."

Lockwood was not at all abashed and at once asked whether I had heard what he had just said, and when I said that I had he went on to say that he would not take it back and that he firmly believed it all. But then, somewhat apologetically, he went on to say that, after all, that frame of mind was by no means confined to Boston, that there were plenty of similar shams elsewhere, and plenty of intellectually or culturally pretentious people in other parts of the country.

"For example," he said, "over in the Catskill Mountains there is an organization known as the Onteora Club, where a lot of writers and artists and their admirers have built a stone wall around themselves and have assumed a holier-than-thou feeling that is displeasing to their neighbors and to people like us who see clearly."

My rejoinder was difficult, but I really had to tell him that I was a charter member of the Onteora Club. He shrugged his shoulders, said good night and went to bed. Was there really anything else he could do at the moment?

The next morning he joined me at breakfast. (He lived out of town and was staying a few days at the Club.) As he sat down he said, "I'm afraid that I owe you an apology. I really know about the Onteora Club only from hearsay, and I may be very badly informed. But I insist that I was right about the Lowell Institute audience."

Of course I told him all about the Onteora Club (the real truth), and we had a very pleasant talk together. It turned out [86] 


\section{THE STORY OF AN ENTOMOLOGIST}

that in addition to being a famous painter, he was greatly interested in raising ducks and he told me especially about the spoonbill variety. He said that their bills are so shaped that they skim off things on or near the surface of the water and that in this way they swallow many mosquito larvæ.

I am constantly reminding myself that this is "The Story of an Entomologist," not the story of his family life, or of a lot of other things that I have told about that might be thought extraneous. But they will work in, and some of them, I am sure, are fairly interesting.

I have said that in I886 I married, and I think I should say a little about this. I married a very charming girl who lived in Washington and whose parents came originally from Maryland. The bald facts are that I built a little house in Washington Heights in which we lived for a time and then moved to old Georgetown. My wife was very musical and so was I. For six years we had no children, and then at intervals of four years our three daughters were born, all in Georgetown. In I90I we moved back to northwest Washington and lived there for many years. There has been almost nothing in our family life that would be of interest to anyone but ourselves, but it has been a very happy one. Mrs. Howard died in 1926, but the three daughters are rather remarkable and very delightful and mean a great deal to me.

There is one thing, however, that rather stands out and that is, after our first daughter was born, we built a little summer house in the Catskill Mountains in a community that has come to be known as the Onteora Club. This colony was founded by an aunt and an uncle of mine, Mrs. Candace Wheeler and Francis B. Thurber. Of course this is the club spoken of in the preceding anecdote about Mr. Wilton Lockwood. This summer home 


\section{FIGHTING THE INSECTS}

has been of great advantage to all of us. Through it we have met many distinguished and delightful people, including many writers, artists, and other persons of note. The children grew up there from babyhood, and I think that during school days they looked upon Onteora as their real home and Washington simply as the place where they had to go to school. I was never able to spend much time there myself until I retired in 1927 , since summer was always my busiest time. But every year I usually managed to put in a week or ten days up there during which time I formed many friendships. I need not mention any of the fine people who have been going there for years and who are members of the Club, for it has been done many times, most recently, perhaps, by Hamlin Garland in one or two of his later volumes.

Inasmuch as we have touched upon the subject of ways and means in this chapter, I must point out that to a certain extent my own experiences and life in Washington for so many years must have been to a certain extent typical of the average government employee, more particularly of those engaged in some one of the scientific bureaus. And this leads me to say something about the wives of these men. Here and there a man of means has, with his wife, shared the rather odd social life of Washington, but such cases have been rare. Nearly all of the scientific people have been comparatively poor, dependent almost solely on a small government salary. I have known, in one way or another, many of the wives, and I never knew what may be called a "social struggler" among them. They have been wrapped up in their husbands' scientific careers, and have made every necessary sacrifice gladly, without pointing out, and apparently without realizing, that they were making such sacrifices. I bow before these women with great admiration, and I wonder if their husbands fully realize what their wives have done for them. When one 


\section{THE STORY OF AN ENTOMOLOGIST}

stops to think of it, there is a lot of pathos in the lives of many of these women, but after all, is there not pathos in the lives of most women? Most of them put on such brave faces that they do not appear to realize it and isn't it lucky for their husbands that this is so? 


\section{Chapter V}

\section{W}

HEN I was told in June, I93I, that the great Capper Award had been made to me, largely because of my special interest in promoting that side of "natural control" that depends upon the work of parasitic and predatory insects, I began to wonder to just how much of the credit I was really entitled. It is true that I had made many investigations concerning Hymenopterous parasites and had begun the study of a limited but important group as early as $\mathbf{1} 879$. This happened in a perfectly natural way. When Professor Comstock was at the Department of Agriculture at Washington, in 1879 , we were rearing certain insects in order to learn their life histories, and in doing this we reared many parasites in our breeding cages. There was no one in the United States who had studied any of these creatures except E. T. Cresson who had described many of our Ichneumon flies. The smaller Chalcis flies of this country were practically unknown. So I took up their study and began to describe new species. In I880 I wrote a paper describing the parasites of the scale-insects, to accompany Comstock's report on these important plant enemies. In the introduction to this report I pointed out the ease with which such parasites could be carried from one point to another to help in destruction of the pests in places where para- 


\section{THE STORY OF AN ENTOMOLOGIST}

sites were lacking, and I soon began a card catalogue of the recorded host-relationships of these useful insects, which comprised the whole world.

A few years later, rather significantly, my address as retiring president of the Entomological Society of Washington, in I884, was entitled: "A Commencement of the Study of the Parasites of Cosmopolitan Insects," and in it I discussed the general question and printed tables indicating the extent of our knowledge of such forms at that time, so far as I had been able to bring them together from the literature.

From that time on I wrote more or less frequently on the subject, and not only continued the great catalogue, but began to see many opportunities for the promotion of natural control work of this kind.

Of course there had been earlier suggestions of this general nature, and these have been referred to by Marchal and by Silvestri in their very much later publications on this general subject. And then, in 1888, came the extraordinary verification of the value of natural control in the introduction and acclimatization of the Australian Ladybird in Southern California. This extraordinary and now famous success, which undoubtedly saved the citrus growing industry of California from speedy destruction, was a good thing and a bad thing. It was a blessing since it started all over the world the long chain of experimental work which after many failures and much expenditure of money is gradually becoming understood and systematized. It was bad only because it aroused many false hopes. In fact, it is safe to say that progress in the battle against injurious insects on the western coast of the United States was set back for ten years or more on account of the supreme reliance on this method of fighting pests and the consequent abandoning of every other means and every other line of research. 


\section{FIGHTING THE INSECTS}

The story of the successes and the failures in experimental work of this kind is very long. I have told it in my "History of Applied Entomology" ${ }^{1}$ and in "The Insect Menace," ${ }^{2}$ so that it is not necessary to go into details here. Some startling, dramatic things have been done. The great sugar-cane industry of Hawaii has undoubtedly been saved by this method. The copra industry in Fiji (their principal industry) has also been saved by the introduction of parasites. The silk industry of Italy has profited enormously by the introduction and establishment of parasites of the white mulberry scale. These parasites were brought from the United States. Now the news has just come that the importation of a little parasite (Coccophagus Gurneyi) from Australia by Mr. Harold Compere under the direction of Harry Scott Smith, has again saved the citrus industry of California from approaching destruction, this time by the Citrophilus mealybug, or at least this introduction has relieved the growers from a tremendous burden.

It may very pertinently be asked, what had I to do with all this? The honest reply is, "Not very much," but I have been constantly writing on the subject and supporting and encouraging efforts of this kind and at the same time have fathered much of what has been done under the direct auspices of the Bureau of Entomology. It is true that some of the greatest successes have been made in other parts of the world, and that successes in this kind of work are much more easily reached in small and rather peculiarly situated countries, and especially in islands, where the climate is equable and where the native fauna and flora are simple. This does not hold for a vast continental area like the United States, and, consequently, although we have done

${ }^{1}$ Smithsonian Miscellaneous Collections, Vol. 84. Washington, Nov. 31, r930.

${ }^{2}$ Century Company, New York, I931. 


\section{THE STORY OF AN ENTOMOLOGIST}

much that counts over here, our work has not been especially spectacular in its results.

I have always contended, however, that it would be an excellent thing to do if we could bring into the United States from all of the parallel life zones of the world as many parasitic and predaceous insects as can possibly be acclimatized. And I have been furthering this as far as possible.

There has, in fact, grown up in the Bureau at Washington a very considerable force of trained young men who are devoting themselves almost wholly to such work, and we have had travelling experts in many of the European countries and in Japan, China, South America, and India as well, studying the parasites of a number of the insect pests of foreign origin that have established themselves in the United States, such as the Gipsy Moth, the Brown-tail Moth, the Alfalfa Weevil, the Japanese Beetle, the European Corn-borer, the European Elm Leaf-beetle, the European Earwig and others.

Many of my most interesting experiences have been connected with efforts to establish relations with different European countries to bring about a steady introduction into the United States of the European parasites of the Gipsy Moth and the Brown-tail Moth. As early as 1905 I went over, at the expense of the state of Massachusetts; and in 1906, and almost annually thereafter until the outbreak of the World War, Congress appropriated funds so that I was able to do the work at the expense of the Federal Government. I had visited Europe before at governmental expense, although for a different object, and had made personal friends among certain of the European workers. The quick response that I received from the scientific men over there to my request for advice and help was inspiring. From the very start, learned and important officials like Marchal in Paris, Berlese and Silvestri in Italy, Porchinski and Mokrzecki in 


\section{FIGHTING THE INSECTS}

Russia, Heller in Germany, F. Rebel in Austria, and Joseph Jablonowski in Hungary, advised me and helped me no end, and, largely on their advice, I established in several countries a regular service through which for years parasitized Gipsy Moths and Brown-tail Moths in their early stages were sent to Massachusetts.

As a matter of fact, before starting on this work, I knew more about the parasites that had been recorded in Europe as attacking both the Gipsy Moth and the Brown-tail Moth than any of my European colleagues. That, of course, was because for twenty years or more I had been hard at work cataloguing the European publications. Nevertheless, each man of those I have mentioned knew pretty well the principal enemies of these destructive pests as they occurred in his own country, and some of them were able at once to put me in touch with collectors who began immediately to help us out.

For example, the people at the great Museum in Vienna told me about a young man named Fritz Wagner. I looked Fritz up, and went out on an expedition with him. We found in one of the Vienna suburbs some street shade trees (I think they were what we call locusts-Robinia pseudacacia-in the United States) that had been partially defoliated by the Gipsy Moth, and on the bark of these trees there were many little white cocoons of an efficient and important parasite. Then we went on out to the famous Napoleonic battlefield of Wagram, and there we found some poplar trees whose trunks were fairly speckled with these white cocoons. So Fritz Wagner knew what we wanted, and for some years sent to Boston large numbers of boxes full of these parasite cocoons and of Gipsy Moth caterpillars that had been stung.

After this I went on to Budapest. The people at the Hungarian National Museum took a courteous interest in my mission, but 


\section{THE STORY OF AN ENTOMOLOGIST}

offered no definite help. I inquired about a correspondent, Josef Jablonowski, and was answered that he was not a scientific man, but a kind of farmer who taught in the Viticultural Institute over in old Pesth. At that time (this was in 1905) such an attitude on the part of the Museum workers did not shock me, as applied entomology was hardly recognized as very scientific by the museum and university people. Fortunately we have gone away beyond this, and Jablonowski, at the time of his retirement in 1928, was a recognized scientific force in Hungary, as well as all around the world.

In spite of this discouraging comment, I crossed the Danube and rejoiced in my soul at the first sight of Jablonowski's beaming and welcoming face. He was then a man of perhaps fortyfive years of age. He was able to give me an important point at once. He showed me a dry-goods box with a wire gauze cover, and in the box were some of the previous winter's nests of the Brown-tail Moth. He told me that in the spring he had seen minute winged parasites on the underside of the gauze cover, and this of course meant to him and to me that there are parasites in these over-wintering silken nests, and that we had only to collect these nests in large numbers and ship them to the United States.

But there was always the possibility that these minute creatures were not parasites of the Brown-tail Moth, but that they had simply crawled into the nests for protection during the winter. Jablonowski and I could not understand each other perfectly at that time, since his French was not of the best and mine was even poorer, but I gathered that he was emphatically of the opinion that the little creatures he had seen were true parasites of the Brown-tail.

At all events, I was prepared to take the risk, and as a result during the following winter many thousands of these silken nests 


\section{FIGHTING THE INSEC'TS}

were received in Massachusetts, coming from Transylvania, from the Hartz Mountains, from Switzerland, and Northwest France. I feel reasonably convinced that the practical disappearance of the Brown-tail Moth as a pest in New England is due, partly at least, to my first interview with this charming and enlightened man, who was at that time at least thought by his contemporaries in the Museum in Budapest to be "not a scientific man, but rather of the farmer class."

Those years of annual visits to Europe were full of interest and of unusual episodes. I remember very well that in 1905 (the year when Paul Marchal was president of the Entomological Society of France) I addressed the Society in Paris on the general subject of our need of these European parasites in the States. What I said was published in the Journal of the Society, and this met the eye of René Oberthür of Rennes. As this splendid man told me afterwards, he feared that the members of the Society would not be able to do anything for me, and so he at once offered me his services. He and his brother Charles were the heads of the great Imprimerie Oberthür of Paris and Rennes, which for years did much of the printing for the French government. During the winter, in the vicinity of Rennes, he had no less than ten thousand nests of the Brown-tail collected and sent to the United States. He did this entirely as an act of courtesy, and would accept no compensation. The following year one of Marchal's assistants (André Vuillet) was employed by us, and stationed at the Oberthürs in Rennes, where he studied parasites and sent over large shipments. Vuillet was killed in the first year of the World War, but his widow took up his work, and was one of Marchal's laboratory assistants, for some years, when she married again. She is now living in Algeria.

Still, through René Oberthür, the work was continued in the South of France. I took up one of his collectors, Harold Powell, 


\section{THE STORY OF AN ENTOMOLOGIST}

for a time, and later secured another man, M. Dillon, who largely used soldiers on leave to collect caterpillars that had probably been parasitized.

In some of the out-of-the-way places in the Department of the Bouches-du-Rhone, the peasants became greatly interested in this work, and wondered why we were doing it. A very old peasant explained it on the ground that it is a well-known fact that every millionth caterpillar has a diamond in its head, and that this was a somewhat laborious American way of accumulating a fortune.

It was on my first visit to the Midi on this mission that I had an unusual experience. I called on Dr. Siepi, at that time Headkeeper of the Marseilles Zoölogical Gardens, and I found visiting him no less a person than Mistral, the famous Provençal poet. Siepi promised to collect for me predatory beetles that destroyed the Gipsy Moth caterpillars, and Mistral showed much interest in the plan. He asked me if I knew his friend, J. Henri Fabre, at Serignan, and offered to introduce me to Fabre if I would go down to Arles with him the next day. I did so, and thus first met the "insect Homer" through the courtesy of the great poet.

About four years after Fabre's death, I visited Serignan, in company with Dr. Marchal and M. P. Vayssière, and wrote an account of the visit which was published under the title of "A Pilgrimage to the Home of Henri Fabre."

During those early years much of the search in Europe for these particular parasites was done in France, and we owe much to the encouragement and assistance given to us by the French experts. There are many interesting incidents connected with our French experiences.

Along about 1909 it became obvious that nursery stock which was being received in several parts of the United States direct from France carried the eggs of the Gipsy Moth and nests of the Brown-tail Moth directly into hitherto uninfested parts of 


\section{FIGHTING THE INSECTS}

our country, and this was used by us as one of the arguments in favor of the passage of a plant quarantine law.

In that year, therefore, I visited the great nursery-growing regions in France, and found that it was a season of unusual abundance of both these insects. The road-side oaks and hedges in Brittany and Normandy were defoliated by the Gipsy Moth, and the fruit trees and forest trees carried many nests of the Brown-tail. In fact, caterpillars of many kinds were unusually abundant. It is worthy of mention that a year later, I9Io, exactly the opposite conditions were found: caterpillars of all kinds were scarce, no Gipsy Moth caterpillars were found, and very few Brown-tail.

In the course of my igro trip I hunted up M. G. Fermaud, the agent of the Franco-American Seedling Company of Geneva, New York and Angers. I had met him the previous year, and had found to my surprise that he had lived long in America and had married an American girl as his first wife, so that his children by this wife, then nearly grown, were practically American. As agent for his company, M. Fermaud was growing nursery stock in many different small lots in the country around Angers. In order to show the clean condition of the stock in the field, he took me to one place after another where farmers or agents were growing young apples and other fruit stock for subsequent shipment by his company to America.

At one place in the suburbs of the city of Angers we stopped at a gate in a high stone wall, which reached nearly to the tops of the small stone buildings within and near by, and he said to me, "Here is one of the men who is growing stock for me, and who, by the way, is one of the most successful flower growers in France, making a specialty, perhaps, of roses." We entered, and found ourselves in a perfect paradise of flowers. Row after row of magnificent rose-bushes of different varieties, many of 


\section{THE STORY OF AN ENTOMOLOGIST}

them in blossom, and bed after bed of annual plants, producing such a mass of color as I had never seen before except in Holland during the tulip season, and in the Great Basin of California in the blossoming time of sweet-peas and nasturtiums.

Inquiry of a laborer led us down into a part of the garden where we found the owner, who was introduced to me as $M$. Théophile Gautier. I was dumb for a moment with the recollection of the brilliant author of "Le Capitaine Fracasse" and of "Mlle. Maupin," for here in front of me was apparently a hornyhanded peasant in rough corduroy trousers, belted, with sabots on his feet, and a weather-beaten countenance and straggly brown beard, but with eyes of keen intelligence. He greeted me cordially and showed us about his place. We examined his stock and found it clean and free from insects and diseases. I took his photograph, standing in his field, and promised to send him a copy. He told me that he was the originator of several new varieties of roses. One of these he had named after the Czar of Russia, a fact which had brought him a letter of thanks from his Imperial Majesty. He cherished this document highly.

We were pressed for time, so we soon left M. Gautier, marvelling at his skill as a horticulturist, and the fact that a man of his standing, and apparently so prosperous, should retain his peasant costume and his little stone house and his extremely simple style of life.

On my return to America, I sent a copy of the photograph of Gautier to M. Fermaud, but heard nothing further about it. 'Two years later, in the summer of 1912, I again visited Angers, and, in company with M. Fermaud's eldest son, once more visited some of the stock plots of the Franco-American Seedling Company. I suggested to young Fermaud that we look up Gautier, and so we did. He recognized me at once as the man who took his photograph, and called his wife and introduced me. He 


\section{FIGHTING THE INSECTS}

sent a messenger down the street after his two sons, and immediately began picking flowers to give me. I told him that I did not know what I should do with them, but he cut an immense armful and carried it out and put it in our automobile. He urged me to come into the little stone cottage and have a glass of wine with him. Then he insisted on my taking a photograph of the whole family, including his wife and his two sons. Mme. Gautier was in her working clothes and protested, but was overruled. Two big, manly, fine-looking sons came hurriedly in, and two or three neighbors, including the butcher next door, joined the group. We all had some more wine, and Gautier showed me a diploma of Officier de l'Ordre de Mérite Agricole that had been given him by the President of France since my last visit. I knew how highly the decoration of Chevalier of this Order is prized by some of my colleagues in America, and to find this apparently simple peasant with such a decoration was a surprise. I photographed the group, took some shares in a raffle for a bicycle for the benefit of a church to which one of the sons belonged, refused to take shares in a raffle for another church in which the butcher was interested, and left with hearty handshakes all round.

Fermaud told me that an injurious insect was never allowed to live on Gautier's place, and that his skill with flowers was almost uncanny. His decoration by the government was highly deserved.

This episode proved to me again what I had already believed: that French democracy is even more intense than our own. And it also seems to indicate that the giving of decorations, when properly done, as it appears to be in France, is something that we really miss, and perhaps need, in the United States.

The coincidence of the name with that of the famous poet and novelist seems to be simply a coincidence, as this modern [ 100 ] 


\section{THE STORY OF AN ENTOMOLOGIST}

Théophile Gautier was not aware of any relationship. The carload of flowers, by the way, was carried to the Convent of Sacré-Cœur in Angers, and given to the Mother Superior for a novice who was the daughter of one of my colleagues in the United States Department of Agriculture.

To go back to the parasite importations. After I had engaged Fritz Wagner in Vienna, and E. Schlöpfer in Dresden (the latter on the advice of Dr. Heller), I went to Switzerland and looked up Dr. Herbert Haviland Field, the Director of the Concilium Bibliographicum Zoölogicum, who at once introduced me to one of his principal helpers, Fräulein Marie Rühl, who was a competent entomologist, and through whose services the United States surely profited greatly. Her father had started a small but well-known journal, called Nature Novitates, which she had carried on after his death. She therefore knew by correspondence very many collectors, especially in Switzerland, Germany and Austria, and for a number of years was able to assemble thousands of parasitized Gipsy Moth larvæ and Brown-tail nests in Zürich, where she packed them uniformly and sent them on to Massachusetts.

Miss Rühl carried on this work successfully until the outbreak of the Great War. I saw her in Zürich in 1925. She was still working for the Concilium, which, after Dr. Field's death, had been taken over by the Swiss government with the financial aid of many foreign organizations. I learn that since then Miss Rühl has died. She was a fine woman and a useful one. She will always be remembered by the force in Washington.

But this was by no means all we did in Europe before the war in this particular investigation. As early as 1907 I went out into Russia. I had corresponded with Professor N. Porchinsky of the Ministry of Agriculture at St. Petersburg, and he had [IOI ] 


\section{FIGHTING THE INSECTS}

written to several experts in Little Russia and Bessarabia, telling them of my coming and my purpose. So in the early spring of that year I took the Oriental Express from Paris down to Budapest, picked up my former courier, Alexander Pichler, a capital fellow who for years was one of the leading couriers of Southeastern Europe, and started to the northeast for Kiew. We broke the journey at Lemberg, in Galician Poland, a place later to become famous in the great World War. The country from Budapest to Lemberg seemed one gigantic wheat-field. Previous to leaving Budapest, I had met in the lobby of the Hotel Hungaria a number of men connected with great grain firms in Liverpool, who had come down in the spring to look into the prospects of the wheat crop for that year, and who told me that it was an annual journey for them. Eventually reaching Kiew, I met by appointment Professor Waldemar Pospelow of the University there, a slender, handsome, blond-bearded young Russian of high scientific attainment, and with him talked over the question of the Russian parasites of the Gipsy Moth. He recommended to me the desirability of renting a garden in the suburbs of Kiew, and conducting there through the summer a large number of rearing experiments with the parasites of both the Gipsy Moth and the Brown-tail Moth, and to make at the same time some biological studies concerning them. I fell in with this plan very readily. This was the first bit of work of this precise kind that was done for us in a foreign country. One of Pospelow's graduate students was engaged for the season (I have forgotten his name). The garden had already been selected, and I advanced money to Pospelow to complete the contract and to pay the rent for the first two months. It was a large garden filled with fruit trees-in fact, it was an orchard rather than a gardenand probably covered two or more acres. The rental price was fifteen dollars a month. 


\section{THE STORY OF AN ENTOMOLOGIST}

After a day in Kiew, a beautiful place on the banks of the Dnieper (then in flood), and with an extraordinarily beautiful cathedral, we took train for Odessa, and from there made a trip to Kischiniew, where a similar station was established under the charge of Professor Isaak Krassiltschik.

Returning to Odessa, we took boat for Sebastopol, where I found letters from Professor Sigismund Mokrzecki of Simferopol, a well-known economic entomologist, asking me to meet him at Bachtisserai, halfway between Sebastopol and Simferopol, in the heart of the agricultural region of the Crimea. As it happened, dear old Pichler, the courier, had developed an enormous carbuncle between his shoulders, which completely incapacitated him. So, leaving him in the hands of a surgeon, I started with the hotel porter, who spoke German, on the morning train to Bachtisserai. On the station platform there I met Mokrzecki, accompanied by the Chief of Police and his bulldog, and by a General Müller, who had come with him from Simferopol as interpreter, since he had spoken English since his boyhood days passed in an English school. The porter from Sebastopol took the train back to that city, and the three of us proceeded to an enormous farm owned by a count whose name I have forgotten, where we were met by the manager, a most intelligent man by the name of Andrieff. Neither Andrieff nor Mokrzechi was content to wait until their Russian was translated into English by General Müller, so, since Mokrzecki knew a little German, and Andrieff rather more French, the conversation was mostly carried on in those two languages, except when General Müller insisted on talking to me on his own account.

We spent the next two hours walking through the enormous apple orchards of the estate, which were at that time in full bloom (it must have been about the sixth of May). Never have I seen finer trees or more healthy ones. At the recommendation 


\section{FIGHTING THE INSECTS}

of Mokrzecki the manager had purchased American spraying machinery and had built a fumigating house for all nursery stock. The orchard seemed singularly free from insect pests, with the sole exception of the apple weevil, which, although quite abundant, apparently had done little damage.

After two hours' walk in a hot sun we went to the mansionlike farmhouse, and were introduced to Mme. Andrieff and her children. She had made ready a wonderful luncheon, at which all sorts of dishes of which I was ignorant were served. A great loaf of Passover bread was on the table, and many other kinds of bread, stuffed with meat and with fish. Many bottles of champagne were opened, and Andrieff made an enthusiastic and altogether too complimentary speech in French.

All of us then went to the village of Bachtisserai, and spent the rest of the daylight hours going through the old Palace of the Khan of the Crimea, a wonderfully beautiful structure, although somewhat dilapidated. It had been the purpose of the Czar to maintain this as an historical museum of the Tatar régime in that part of Russia, but the plan had been stopped for the time by the financial embarrassment caused by the RussoJapanese war. There was only one caretaker, and everything was covered with dust. The famous Countess Potocka was at one time imprisoned in the place, and there is a fountain in the palace known as Les larmes de Potocka. The palace is built of wood, but it is very beautiful and wonderfully effective. It was used at one time as a winter resort by Catherine the Great. Delightful and picturesque as this place is, it seems rarely to have been visited by tourists.

At nightfall we boarded the train again, and arrived before bedtime at Simferopol. The following day we spent at the Mokrzecki museum, a very good regional museum which Mokrzecki had built up by his own efforts, and which was 


\section{THE STORY OF AN ENTOMOLOGIST}

devoted to the fauna and flora of the Crimea, spreading out a bit into the general fauna of the Black Sea region. The collection of insects had a much wider range, and included a great deal of material from other countries.

As had been the case with other European official entomologists, Mokrzecki entered at once into my plans for the introduction of parasites of the Gipsy Moth into the United States, and would not hear of any remuneration from the state of Massachusetts or from the United States government. He had already reared an egg parasite of the Brown-tail Moth and was subsequently of much help to us.

In anticipation of my arrival, Mokrzecki had prepared an elaborate address of welcome, illuminated by a clever artist in the museum and beautifully bound in Russian leather. I was amused to read in gold letters on the cover the words "Sir Leland Howard," which indicated that someone had confused American customs with English ones. Mokrzecki lived very comfortably and had a beautiful wife, as well as a young son and daughter.

There was an incident connected with my departure which could hardly have happened in any other country at that period. About five o'clock in the afternoon we all went to the train, a party of perhaps eight or ten, including Mokrzecki's family, the Chief of Police, a prominent advocate, General Müller and Mokrzecki's assistants. We all stood on the station platform for perhaps a half-hour, awaiting the train and talking together in an animated way. Next morning at Sebastopol I received a telegram from the Chief of Police at Simferopol, warning me that a suspect had been seen to enter the carriage next to mine on the train. He was described as a short, robust man of the working class, with a strong mark on his forehead. The Chief apologized for the warning and said that my Simferopol friends were 


\section{FIGHTING THE INSECTS}

anxious about me, and that perhaps I did not know they were living in troublous times. I never saw the suspect, but I learned later that the week before my arrival a bomb had been thrown by some anarchist into the Police Station.

The next day or so, while we were waiting for the Black Sea boat for Constantinople, we spent in Sebastopol and the surrounding country. There was an interesting Marine Biological Station, not so elaborate as the one at Naples, nor so extensive as that at Roscoff, but well equipped and in the charge of a very intelligent zoölogist. I was especially impressed by the library of periodicals, which seemed to contain about everything worth while. It may be interesting to state that a few years after my visit Dr. Paul Galtsoff became the director of this station. He later escaped when the Red Army overwhelmed the Crimea and is now holding an important position in the Bureau of Fisheries at Washington.

While I was seated at luncheon on one of these days (Pichler was still in bed with his carbuncle) a card was brought to my table, and I asked the waiter to show my visitor in. A large, handsome, bearded gentleman entered with a large volume in his hands and introduced himself in fairly good English as Mr. Constantinoff. He explained that he was the Manager of the Black Sea Line of steamers, and that he had come on behalf of the Mayor of the city, Mr. Maximoff, who was detained by official duties, but who greatly desired to have me see his country place and his large vineyards. Mr. Constantinoff had been selected by him as the only man of his acquaintance who knew English (the large volume was a dictionary of Russian-English and was intended to facilitate conversation). I accepted the invitation and we drove out to a beautiful hilly estate beyond Balaklava, where the manager of the estate was introduced, and where we spent the rest of the afternoon in the vineyard or on the grounds 


\section{THE STORY OF AN ENTOMOLOGIST}

or in the wine cellars. The estate was large, and the Mayor must have been a very wealthy man. His vineyards were in excellent condition, with no evidence of Phylloxera or, in fact, of any injurious insects. The buildings were all of a glaring white, modern, very handsome, with good architectural lines, but strangely ornamented by a series of patterns, the unit of which was a round black spot, a little more than two inches in diameter. Constantinoff told me that these spots were the butts of champagne bottles that had been picked up on the ground when the estate was bought. He accounted for their presence by the fact that the French troops, during the Crimean War, were encamped on that part of the Peninsula. The bottles had been set in cement and formed a very artistic ornamentation to the building.

In a spare hour I was unwise enough to visit the War Museum, which was connected with a great panorama of the Crimean War. I got from this museum the best idea that I had ever had of the horrors of war, and it caused me many a nightmare later.

It is a wonder to me that so few tourists have visited that garden spot of the Crimean Peninsula. The scenery of the rocky place on the coast known as Ialta is of the most beautiful and impressive character. The old palace at Bachtisserai was one of the greatest curiosities of Europe. The climate of the whole Peninsula was delightful, the hotels were good, and the people were hospitable. The descendants of the old Tatars were still living there in numbers.

But I must not leave Mokrzecki with this brief mention. Great trouble was to come to him, as well as to my other Russian scientific friends. After the Second Revolution and the overthrow of the Kerensky Government, the Red Armies spread through Little Russia and invaded the Crimea. As is well known, thousands upon thousands of people fled before them into Sebastopol 


\section{FIGHTING THE INSECTS}

and boarded vessels of many nations anchored in the harbor. It must have been a scene of frightful confusion. Mokrzecki and his daughter managed to reach a vessel that carried them to Constantinople. His wife and son probably boarded some other vessel. At all events, they were separated and, so far as I know, they have never come together again. Eventually Mokrzecki and his daughter reached Belgrade, where for a time he taught in a local institution. I have since met one of his laboratory assistants there, Madame Anna Bragina, a most intelligent woman, who had studied in Jugoslavia the parasites and the ecology of several imported pests, and who, since the war, has been of much assistance to the experts of the United States Bureau of Entomology. Later, Mokrzecki and his daughter went on to Poland. He is now in charge of the entomology at the important agricultural college at Skierniewice, where I visited him in 1927. The little girl whom I had known in the Crimea twenty years before had grown into a beautiful woman and was married, but she and her husband lived with her father, who then held, and still holds, a high place in the esteem of the agricultural ministry of Poland.

Many stories could be told concerning the work I did in Europe between 1902 and 1912 , relating to this parasite introduction. A number of countries were visited, and I had some amusing adventures. Excellent services were started in a number of countries, and hundreds of thousands of parasitized caterpillars were sent to the United States. The most perfect arrangements were made with the European shipping authorities, and the late United States despatch agent of New York, Mr. I. P. Roosa, took the keenest interest in the work and helped us in many ways. I should say a special word for the American Express Company. The agents of this organization at Paris, Marseilles and Havre, at Hamburg and at Naples, may have re[ 108$]$ 


\section{THE STORY OF AN ENTOMOLOGIST}

ceived instructions from headquarters, but they helped the government very intelligently and very greatly. An expert of the Bureau, Mr. J. N. Summers, was caught in Germany at the beginning of the World War and got home with difficulty. The war, naturally, stopped all of the importing work. But of late years it has been resumed to some extent, and skilled experts of the Bureau have been maintained in Eastern Europe, to rear and send over promising parasites that we had not received in sufficient quantity before the war. For some years a laboratory for this purpose was maintained by our government in Budapest, and such work has also been done in Poland, Czechoslovakia and Jugoslavia.

While nothing spectacular has been accomplished by this introduction of the parasites of the Gipsy Moth and the Brown-tail Moth, there is absolutely no doubt that the introduced parasites have aided very greatly indeed in our fight against these pests.

I tried to get into the World War, although far past the age for active service. I felt sure that I could do something as a liaison officer, because of my knowledge of the French language and my personal acquaintance with many leaders among the French scientific men.

After the war there was one of these parasite introductions of a reversed kind, that is, from America to Europe, instead of from Europe to America, in which I played a small but direct part. There is, native to the United States, a plant-louse that lives upon the roots of apple and pear. It is a little bluish creature covered with white stringy wax that gives it a woolly appearance. It is known over here as the Woolly Root-louse of the apple (Schizoneura or Erisoma lanigera). One hundred and fifty years ago or more this insect was accidentally imported through commerce into England, and by like means it spread later to France 


\section{FIGHTING THE INSECTS}

and many other portions of the world. It is known in other countries as "The American Blight." In most parts of America, especially where the soil is light or rather sandy, this pest lives principally upon roots; but in England and France, especially in clayey soils, it multiplies enormously aboveground and seriously drains the vitality of the trees.

When in the United States this insect appears aboveground on suckers from the trunk, it is destroyed by many other insects, but particularly by a very minute parasite known as Aphelinus mali.

Dr. Paul Marchal had talked to me about the advisability of importing this parasite into France, but soon after that the war came on and all else was forgotten. When peace came, and rehabilitation on a large scale began in France, Marchal's functions were enlarged, and he was given more assistants, which enabled him to establish several field laboratories. Then he was ready to attempt the introduction of the Aphelinus. We were only too glad to have a chance to help him, for we owed him much. So in the spring of 1920 I had men in several different parts of the United States gather twigs of apple and pear, the twigs selected being, for the most part, suckers bearing the dead and swollen bodies of the plant-lice. Each of these swollen bodies contained a dormant parasite. These twigs were carefully packed in small boxes, and the boxes themselves were made into a packet a foot or so square. In late May I started out with this packet in my luggage. While at Washington it had been kept at a temperature of about forty degrees F. Arriving in New York, I boarded the boat and at once consulted the Chief Steward. By his orders, the man in charge of the meats placed the packet upon a shelf in his refrigerating room, the temperature of which I was assured ran from $37^{\circ}$ to $4 \mathrm{I}^{\circ} \mathrm{F}$. Each day of the journey the temperature of this room was reported to me, and 


\section{THE STORY OF AN ENTOMOLOGIST}

at no time did it exceed $39^{\circ}$. (Previous work had shown that the insects became active only at $42^{\circ} \mathrm{F}$.) I arrived in London late at night. The weather was cold, and I placed the packet on the window ledge outside my room. Early next morning I looked up a fishmonger and got him to put the packet in his cold room, since for two or three days I had to attend the important triennial meeting of the Imperial Bureau of Entomology.

Then one morning I took it out, boarded the boat train, reached Paris at four o'clock in the afternoon, and was met at the Gare du Nord by Dr. Marchal. We hastened across Paris in a taxi to his laboratory in the Rue Claude Bernard, where a pear tree, well covered with the Woolly Aphis, stood in a large pot covered with gauze. The surface of the ground in the pot in which the gauze-covered tree had been planted was covered by white paper.

Now was the interesting moment. The laboratory assistants gathered around. The gauze was removed. The boxes were opened one by one, and their contents were dumped on the white paper. To our great chagrin we saw at once that many (possibly all) of the little black parasites had already issued and died. Their minute black corpses showed plainly on the white paper. It was a great disappointment, but we placed the gauze over the tree again and left it.

The next day Marchal and I started on a long journey to visit his laboratories in the south of France. We went by train to Lyons, and thence by boat to Avignon. There we were met by a government automobile driven by a soldier and were carried off to Arles, where we were joined by P. Vayssière, with whom we went south to the Gulf of Fos, incidentally visiting several places to see the work against the Moroccan locust. We stopped, by the way, at J. H. Fabre's old place at Serignan, and at Orange, where we called on Vayssière's charming old grandmother, then 


\section{FIGHTING THE INSECTS}

proceeded to Montpellier, where we spent a day with Picard. And it was here that we had the first encouraging news from Paris. Marchal received a telegram stating that ten living Aphelinus had emerged from the odds and ends on the paper under the pear tree!

We then went on to Marseilles, and later to Menton, to see the Insectarium then existing there under the charge of Poutiers. There we had more good news. Another telegram came from Paris. Two hundred more of the Aphelinus had emerged.

A few days later I went down into Italy, and when I found myself in Paris again, late in August, the grandchildren and great-grandchildren of the survivors of the parasites I had brought over were existing in Marchal's experimental garden literally by millions.

Thus, apparently, there had been added to the French fauna a new element that promised to be of great use. But the question as to whether it would pass the winter successfully was still unanswered. It did. And from that beginning it has been sent from one country to another, establishing itself successfully in practically all of the more southern countries, where it has helped greatly to settle one of the serious problems of the fruitgrowers. In the more northern countries it has not done as well. I am told that in England it has not proved of great value. Recent reports, however, show that in certain of the Balkan countries it is doing very well.

But this is not all. A South African student, Mr. A. E. Lundie, studying at Cornell University a year or so later, sent woolly root-lice parasitized by this Aphelinus to South Africa, and in certain places in the Union it is said to thrive. Moreover, after my return to the United States I sent the species in number to Uruguay, and from there it was sent to other South American countries. The reports concerning its work are enthusi[II2] 


\section{THE STORY OF AN ENTOMOLOGIST}

astic, and it is said to have done away with the pest. Again we sent from Washington boxes of the parasite collected in different parts of the United States to Dr. R. J. Tillyard at Nelson, New Zealand, where they were cared for and liberated with enormous success. Tillyard sent specimens to L. J. Newman in Australia (at Perth), who also reports enthusiastically. The first sendings to Japan have failed to take hold, but other experiments are on the way.

Thus Aphelinus mali has shown itself to be a potentially cosmopolitan species. And it is a great joy to realize that I had something to do with its spread.

This general subject of natural control is an attractive one. There have been many failures and much unnecessary waste of money, but the great successes have far more than compensated for this expense. And, judging from present reports, there is no doubt that work of this kind will be carried on for a long time to come. Many men whose names might be mentioned have taken prominent part in this work. It seems to me, however, that we should remember especially C. V. Riley, Albert Koebele, Frederick Muir, and W. F. Fiske among the earlier ones. It is true that George Compere was an indefatigable worker along this line, but Compere was not a trained entomologist, and in spite of his admirable persistence, coupled with his great enthusiasm, his labors as a whole did not add greatly to our knowledge.

Although Albert Koebele was a great friend of mine, the published mentions of this admirable man have, I think, been over-enthusiastic. As I have stated previously, I am convinced that an expression that has crept into the German entomological literature-"the Koebele method"-as applied to natural control is a mistake. Koebele was a keen-eyed collector and a surpassingly good preparator, but he was not a scholarly man. $\mathrm{He}$ 
had had almost no education and he was not a broad entomologist.

While W. F. Fiske's work in a quite different region did not bring about the spectacular results that came from Koebele's sending of the Australian Ladybird to California, he was a welltrained and extremely thoughtful and ingenious man. His work at the receiving end of the sendings of the parasites of the Gipsy Moth and the Brown-tail Moth from abroad, as displayed in the large volume published as Bulletin 9r of the Bureau of Entomology, has given him a distinctive rank and a very high one among the early workers. And then his subsequent work as an explorer added greatly to his standing.

In a book that I wrote rather recently and that was published in 1931 by the Century Company under the title, "The Insect Menace," I told at some length two of the most striking stories connected with parasite introduction. One was of the late Frederick Muir and his extraordinary and successful efforts in the face of great obstacles to find and to import into Hawaii the parasites of the Sugar Cane Beetle Borer. The other was of Fiske's remarkable achievement in the finding of a certain Gipsy Moth parasite in the forests of Gioatauro, in Sicily, and of his persistence and great ingenuity in securing quantities of this parasite and getting it sent successfully to America. I wish that I could retell these stories here. But I must not do so. They can be looked up easily.

In I896 I published a bulletin entitled, "A Study in Insect Parasitism." I am glad that I did so, not so much because it was a good bulletin, but because it attracted Fiske's attention and turned him toward this line of work. Unfortunately, he left the service about I9I2. He was then commissioned by the English to take up a study of the Sleeping Sickness, and for a time con[II4] 


\section{THE STORY OF AN ENTOMOLOGIST}

ducted an admirably equipped camp laboratory on an island in Victoria Nyanza. When the World War came on, he turned his attention to military service for the British, and since the war

I have lost track of him. He was an exceptionally ingenious man and did great work. 


\section{Chapter VI}

\section{$\mathrm{W}_{\mathrm{E}}$}

E ARE fond of saying that circumstances have conspired to bring about such-and-such a result, and surely a series of different things led me naturally to take a great interest in the subject of the insect carriers of disease. There were plenty of mosquitoes at Ithaca, and long before I read Réaumur's fascinating account of the development of the common rain-water mosquito at Paris in the middle of the I8th century, someone had told me that the little wrigglers in buckets of rainwater and in horse troughs were young mosquitoes. I had not only studied their transformations out of mere curiosity, but I had found that in this aquatic stage they were readily killed by pouring a few drops of kerosene on the surface of the water. But of course I was only a boy, and mentioned it only to my boy friends.

When I came to Washington I developed a slight case of malaria. I consulted a physician, who told me that it was due to my open windows at night-that the miasma came in from the Potomac flats. I shut the windows, took quinine, and got well. But I never had the slightest suspicion that there was any such thing as an Anopheles mosquito. Mosquitoes were bad in most places in those days. The New Jersey coast one was at the height of its reputation, and I remember that it was almost 


\section{THE STORY OF AN ENTOMOLOGIST}

impossible, in many parts of the Northern States, to sit out of doors at or after dusk from late May until September. In Ithaca, where I spent my boyhood, the low-lying part of the city which we called The Flat was very malarious. "Chills and fever" were common, and extended up the West Hill for some little distance. The East Hill, on the summit of which the University was built, and which was gradually covered with private houses, was not malarious. As I look back, I can remember that the presence or absence of malaria in the different parts of the town could plainly be seen by the appearance of the houses and dooryardswell-painted and well-kept on the East Hill, a little more slovenly in The Flat.

From time to time we received letters in Washington asking information about mosquitoes, and I published a number of notes in Insect Life. In I892 I built a little house in the Onteora Club, in the Catskill Mountains, and in the summer found mosquitoes very prevalent. On my land there was a surface pool of water covering about sixteen square feet, and, remembering my boyhood experience in Ithaca, I poured kerosene on it, making a complete surface film. This not only killed the mosquito larvæ, but also the female mosquitoes which alighted on the water to lay their eggs. I read an article about this before the Buffalo Meeting of the American Association for the Advancement of Science, and the newspapers took it up. The article itself was later published in Insect Life.

When I became Chief of the Service in 1894 , it occurred to me that it might be a good idea to write a long and comprehensive bulletin on the subject of household insects, and this I did in collaboration with my assistants, C. L. Marlatt and F. H. Chittenden, each of us signing the portion which he contributed. Mosquitoes, the housefly, and certain other insects fell to my lot, and before writing I studied their biology rather carefully. 


\section{FIGHTING THE INSECTS}

Apparently no one had studied the development of the commonest of the rainwater mosquitoes since Réaumur had written in Paris one hundred and fifty years before, and of course I found that in Washington things were rather different.

So I was getting more and more interested in mosquitoes, and later worked out the life histories of several species. Among these was Anopheles quadrimaculatus, afterwards shown to be a malaria-carrier. Then came the announcement of Ross's discovery. I was now ready to publish a bulletin on this subject, but before I did it I sent an illustrated article on the life history of a malarial mosquito to the Scientific American. It was published and attracted much attention.

Almost coincident with Ross's discovery, the Italian school of observers, led by Battista Grassi, had made similar announcements. Dr. W. S. Thayer, of Johns Hopkins University, who had been specializing on malaria, went to Rome to study the matter, and on his return came over to Washington to talk with me about malarial mosquitoes. He became interested in a campaign of instruction on these new discoveries, in the State of Maryland, and I remember lecturing with him at a Maryland town under the auspices of the State Board of Health. I had already lectured before the American Medical Association, before a Medical Association in Texas, and before other audiences in different parts of the country on this general subject.

It resulted from all this that when Dr. Walter Reed, of the U. S. Army, wanted to start a thorough investigation of Yellow Fever in Cuba at the end of the Spanish-American War, he came to my office to make a study of certain mosquitoes prevalent in Cuba, and especially of the one then known as Culex fasciatus, which had been suggested by a Havana physician, Carlos Finley (son of a Spanish mother and an English father), as the probable carrier of Yellow Fever. He brought 


\section{THE STORY OF AN ENTOMOLOGIST}

with him Dr. Jesse W. Lazaer and later Dr. James Carroll, who were associated with him in the famous Yellow Fever Commission. Dr. Aristides Agramonte, a native Cuban, was also a member. The work of the Reed Commission is well known. During all their investigations, Reed constantly wrote to me, not only on questions relating to the different species of mosquitoes, but also to tell me of the progress of their work.

No end of fame has come to the Walter Reed Commission, and the results of its work have done much to revolutionize conditions in the Southern United States, Central and South America and Africa. They have really opened up vast regions for safe settlement by the white race. But since those days the statement has been made publicly that Reed himself viewed his results more from a scholastic or scientific point of view than from the practical. This is distinctly not true, since in his correspondence with me, after he considered that his demonstration of the carriage of Yellow Fever by the mosquito was perfect, Reed dilated on what it would mean to the world, and was kind enough to say nice things about the anti-mosquito measures that I had recommended.

In I90I I wrote a book entitled "Mosquitoes, How They Live, How They Are Classified, and How They May Be Destroyed." ${ }^{1}$ Its publication in the summer of that year, following as it did the announcement of the results gained by Ross and by the Reed Commission, was most fortunate, for it was what is called the "psychological moment." The Surgeon-General of the U. S. Army, George E. Sternberg, saw that many copies were placed in the hands of the members of the Army Medical Corps, especially those stationed in tropical or sub-tropical regions. Its recommendations formed the basis of the clean-up of Havana, and for the early measures undertaken in the Panama Canal

${ }^{1}$ McClure, Phillips \& Co., New York. 


\section{FIGHTING THE INSECTS}

Zone. A little later, as the Bishop of New Orleans told me, it was a godsend to the people of that city when the epidemic of 1905 appeared.

But I was by no means satisfied with this book. The medical discoveries had inspired work relating to mosquitoes and their control all over the world. Andrew Carnegie had just founded the Carnegie Institution of Washington, and I applied for a grant to finance the preparation of an extensive monograph of the mosquitoes of North and Central America and the West Indies. After some delay a grant was made, amounting to two thousand five hundred dollars a year for three years. In the course of those three years the field opened up enormously. I found that there were many more species of mosquitoes than I had supposed, and that there were infinite variations in habit among the different genera. I had employed expert agents living in different life zones, and had associated with me Dr. H. G. Dyar and Mr. Frederick Knab. We found that we could not possibly produce such a work as we wished to bring out at the expiration of the allotted time. But the Institution insisted upon published results before continuing its appropriations. We were therefore left without financial support. But I had secured the help of many voluntary observers, and I also got Congress to appropriate ten thousand dollars each year "for the investigation of insects affecting the health of mankind and animals." Dr. Dyar was fortunately a man of some wealth, and he financed several expeditions to regions that had previously been unknown to us. And so the work went on. Finally, in 1912, we were able to present the manuscript of two volumes to the Carnegie Institution, and in 1917 two more. The work as a whole was received with much interest by the medical investigators, sanitarians and biological workers of the world.

Nineteen seventeen, however, was a long time ago. Knab, [I20] 


\section{THE STORY OF AN ENTOMOLOGIST}

bright little fellow, talented investigator and clever artist that he was, died in 1918 from a disease contracted, curiously enough, from the bite of an insect in Brazil years before. The mass of descriptive work that had been done in different countries was appalling. I applied to the Carnegie Institution for permission to prepare for publication an entire revision of the monograph, but finally, after a number of years, received a notification that but one more volume could be issued, and that this was to be entirely taxonomic in its character. This was not what I wanted, but it was much better than nothing, and Dr. Dyar, who had been keeping up his work all this time, prepared a large volume revising the classification and including many new species, and including also in its geographic scope the entire continent of South America. This the Carnegie Institution published in excellent shape under the title, "Mosquitoes of the Americas." This appeared toward the close of 1929 under the sole authorship of Dr. Dyar, who died soon after.

Harrison Gray Dyar was probably the best posted man on the classification of mosquitoes of his time, with the possible exception of F. W. Edwards, of the British Museum of Natural History. It may be worth while to tell how Dyar became interested in mosquitoes. He had graduated at the Massachusetts Institute of Technology and had studied bacteriology at Columbia University, New York, under T. Mitchell Prudden, gaining his Doctorate in Philosophy by a thesis on the air of New York City. He had always been interested in caterpillars, and in his idle moments in the summers had worked out a classification of these worms (larvæ of lepidoptera). In the summer of 1902, he was, I think, down at Woods Hole, Massachusetts, when he saw my book on mosquitoes, which had just appeared. He was struck with the illustrations of the larvæ of Anopheles, and soon after found some of these in a horse trough. 


\section{FIGHTING THE INSECTS}

Having studied their characteristic markings and structure, he began such work on the larvæ of mosquitoes. And thus began his work with this group which lasted until the time of his death. Dyar, by the way, was a very ingenious and original fellow. While he gave due weight to the opinions of others, these did not greatly influence his original thought. For example, let us take his thesis on the bacteria in the air of New York City. Having done some morphological work with insects, he was impressed by the difficulty in characterizing bacteria, in that they were morphologically so similar. This was at a time when the specificity of these micro-organisms, especially as to their causation of certain diseases, was being insisted upon by the Koch school. But Dyar insisted on the possibility that certain forms considered to be specific might not really be so, but that in different environments they might alter both in character and effect. It is interesting to note that bacteriology of late has been turning in the direction of his views.

But in telling of the preparation of the Carnegie monograph and of Dyar's much later volume and of Dyar himself we have gone far ahead of the story.

When the little book on mosquitoes was published in rgor, a friend came to me and said that he had heard some army people at the Chevy Chase Club talking vigorously about the way I had treated Dr. Reed in the book. I then became aware for the first time that, contrary to what I had stated on pp. 122-23 of the book, Dr. Reed had undertaken his mosquito investigation on his own initiative and without suggestion from the Surgeon-General. I was at that time preparing an article for the Review of Reviews on this general subject, and I went immediately to the Army Medical Museum to explain matters to Dr. Reed. He received me very kindly and said that he 


\section{THE STORY OF AN ENTOMOLOGIST}

could readily see how I had fallen into the error. I showed him the manuscript of my Review of Reviews article, which he approved. A little later another article of mine (illustrated this time) was published in the Century Magazine for October, I903, entitled "Yellow Fever and Mosquitoes," in which the statements were based on exact information that Dr. Reed had given me.

The truth is that while Reed and his Commission were at work in Havana the Surgeon-General of the Army and I met almost daily at the Cosmos Club and talked over matters of common interest. In fact, I talked often with the General on this subject of the carriage of disease by mosquitoes, and, since I was busy that summer working on the insect fauna of human excreta, with a special reference to the carriage of typhoid, we had many discussions on the subject of typhoid in the army concentration camps in I898. I naturally assumed that Dr. Reed had had his definite instructions from the Surgeon-General.

Just here it will be interesting to quote a letter received from Dr. Reed and dated January r3, rgor:

DEAR DR. HOWARD:

I enclose a copy of the Order relating to the Protection Against Mosquitoes. Of course you have already heard from Dr. Sternberg of our complete success in repeating our former observations. The mosquito theory for the propagation of yellow fever is no longer a "theory," but a well-established fact. Isn't it enough to make a fellow happy? Anopheles and Culex are a gay old pair! What havoc they have wrought to our species during the last three centuries! But with Howard and kerosene we are going to knock them out.

With best wishes,

$$
\text { Sincerely yours, }
$$

WALTER REED.

P. S.-Major J. R. Kean, Surgeon, U. S. A., was the Acting-Chief Surgeon of the Division of Cuba at the time this Order was published, and it was he who drew it up and recommended it to General Wood. He should have credit for it. 


\section{FIGHTING THE INSECTS}

This is all very interesting and has much historical value. W. C. Gorgas, who was then a major in the Medical Corps, was put in charge of the clean-up of Havana on the basis of the just proved carriage of yellow fever by mosquitoes.

Shortly after this the United States began the construction of the Panama Canal. The principal sanitarians of the country, remembering the disastrous ending of the effort made by the French under de Lesseps to construct a canal there, were greatly exercised over the sanitary aspects of the problem, and just at the time when the Panama Canal Commission was authorized by Congress, a committee of medical men went before President Roosevelt to urge the appointment of a thoroughly competent sanitarian as a member of the Commission. I shall tell in another chapter the story of this interesting interview. The world knows that Colonel Gorgas, fresh from his clean-up of Havana, was given full charge of the sanitary work in Panama.

Before he started for the Isthmus, Colonel Gorgas called at my office, and brought with him Mr. J. A. Le Prince, an engineer who had been with him in his Havana work, and we talked at some length of mosquitoes and mosquito remedies. I was then planning the Carnegie monograph, and asked Colonel Gorgas if he would have some one collect for me all the different species that could be found down there. He smilingly replied, "I'll have to turn that over to Mr. Le Prince." And Le Prince, with an amiable grin said, "Well, Doctor, I'll have to do it right away, because in a few weeks there won't be any mosquitoes left." I tell this as indicative of the confidence with which the two men went to work. In a book published some years later by Mr. Le Prince and Dr. Orenstein I tell this story in the introductory note that I wrote for the volume, at their request.

In the late spring of I90I I was invited to give the popular lecture before the Royal Society of Canada, and my subject 


\section{THE STORY OF AN ENTOMOLOGIST}

was "Insects and Disease." The Governor-General of Canada presided and introduced me. When I came to the subject of the so-called Tsetse fly disease, I said that it had just been discovered that the disease was not caused by a poison peculiar to the flies, but that they were carriers of the disease organism from one animal to another. I said that this discovery had just been made by Surgeon-Major Bruce, who at that moment was shut up in Ladysmith by the beleaguering Boer Army. I went on to say something about the sympathy that I and my friends had with the British in that war when suddenly a cannon was fired outside the hall. Cheers were heard, a military band struck up, and an aide-de-camp came into the hall, mounted the platform and gave a despatch to the Governor-General, who interrupted me to announce that Ladysmith had been relieved.

Before we leave the subject of yellow fever I must tell one more anecdote. In the summer of $193 \mathrm{I}$, while I was on my way from Washington to France by the western route, we passed through the Panama Canal, and some of the men in the Canal Zone gave me a very delightful dinner at the Miramar Club in old Panama City. One of the speakers (I think it was Dr. Clark, the Director of the Gorgas Institute Laboratories at Balboa, who was with the Sanitarians during the digging of the canal) told this story. He said that one day he remarked to General (then Colonel) Gorgas, "Aren't you weighed down by the enormous responsibility of your task?"

"Not in the least," said Gorgas, "I am carefree, comparatively. On questions of bacteriology I rely on Dr. Welch of Johns Hopkins. On questions relating to yellow fever I rely on Dr. Carter of the Public Health Service. On questions of mosquitoes I rely on Dr. Howard of the Department of Agriculture. Theirs 


\section{FIGHTING THE INSECTS}

is the responsibility. And I don't believe that they feel weighed down by it, either."

This was a graceful and altogether too modest statement, but I was delighted to hear it, as it brought my name in.

But to go back to malaria. Of course the great impetus of Ross's discovery in Calcutta was largely responsible for the fact that Walter Reed took up so enthusiastically his investigations into yellow fever at Havana. He had been much at the Johns Hopkins Laboratories in Baltimore and knew Dr. W. S. Thayer, who had just returned from Italy. Thayer, who had been a great student of malaria, went to Italy to study the results gained by Battista Grassi and his colleagues, who, it will be remembered, disputed with Ross the discovery of the carriage of human malaria by Anopheles, or, at least, the priority of this discovery. I remember well that after this trip Thayer came over to Washington to talk to me about the simplest way to differentiate Anopheles from other mosquitoes. I had pointed out in my publications that in one of the sexes of Anopheles the labial palpi are almost as long as the proboscis, whereas in the corresponding sex of Culex they are very short. Thayer came to me with the astounding statement that he had found the palpi to be much longer than the proboscis, and when I came to examine his specimens I found that he had mistaken the front legs for the palpi. Rather a good joke on so eminent a man!

I had been corresponding with Ross and had sent him my publications, and he in return had sent me his admirable little book entitled "Mosquito Brigades." And then in the summer of 1905 the Board of Directors of the International Exposition held at St. Louis organized an International Congress of Arts and Sciences and sent Simon Newcomb (who was to be the president of the congress), Hugo Münsterberg of Harvard, and Professor Small, the economist, of the University of Chicago, 


\section{THE STORY OF AN ENTOMOLOGIST}

to Europe to invite personally a certain number of eminent men to come over to St. Louis at the expense of the Exposition Fund, and read papers at this great congress. Ross was one of the men invited, and I met him for the first time at St. Louis. He was then a vigorous, apparently athletic, youthful man, I should say in his thirties. I took to him at once, and he was very good to me. We hobnobbed quite a bit, since we were both so interested in the mosquito question. He read a rather important paper in which he went into the question of Anopheles dispersion, treating it somewhat from the mathematical point of view. In talking about this paper with me, he told me that he was more interested in mathematics and in poetry than he was in medicine or entomology.

In the year of the St. Louis Fair, by the way, there was an outbreak of yellow fever at Laredo, and the following year a similar one at New Orleans-the last, we all hope and expect, that will ever occur in the United States. I mention the matter here incidentally because Mr. August Busck, who was then in charge of the exhibit of the Bureau of Entomology at the Fair, found the Yellow Fever Mosquito on the Fair Grounds and breeding in some numbers. It is therefore obvious that should any of the visitors to the Fair from Central American countries have been infected, there would have been a catastrophic outbreak of the disease at St. Louis.

In the following year I was visited in Washington by Professor Rubert Boyce of the Liverpool School of Tropical Medi. cine, and his friend and travelling companion, Viscount Mountmorris. They came with letters of introduction from Major Ross, and arrived, as I recollect, some time in August. Yellow fever was then rampant in New Orleans. I had just returned from Europe, and was trying to finish up accumulated business so that I might go down there. Professor Boyce (afterwards Sir 


\section{FIGHTING THE INSECTS}

Rubert) was anxious to go to New Orleans at once, to watch the work then being carried on so admirably by the U. S. Public Health Service under Dr. J. H. White. I furnished him with collecting materials and warned him that when he got to New Orleans he would probably have great difficulty in leaving on account of the very strict quarantines, which, of course, now seem to us rather absurd. He was quite ready to run all risks, and when I, anticipating his possible difficulties, offered to help him financially, he grinned in a grateful but rather superior way, thanked me and said that Liverpool's shipping interests would keep him supplied with money. I did not know at the time that he was the son-in-law of a great shipping magnate who, I believe, was a backer of the Liverpool School.

Lord Mountmorris, who was with him, was then a young man in his early thirties, and greatly interested in medical work. $\mathrm{He}$ did not go to New Orleans with Professor Boyce, but remained in Washington for some days. I remember that one night a group of us were chatting at the Cosmos Club about national agreements and disagreements and I suggested that national differences were rather trivial as compared to ethnical differences. Turning to Mountmorris, I said, "Speaking racially, I am just as good an Englishman as you are."

"Oh, dear me, I'm Irish," he said, and there was a general and hearty laugh.

Professor Boyce's stay in New Orleans interested him greatly. Dr. White put him upon one of the important committees, and he worked hard. But the emergency was soon past, and he was able to get away to the West Indies in the early autumn. His experiences are well described in his very readable book "Insects and Man," published in England a year later.

But although I started to get back to malaria, I see that I have been writing of yellow fever again, and I must really add [128] 


\section{THE STORY OF AN ENTOMOLOGIST}

a word or two about my own impressions of New Orleans during that fateful year. I returned from Europe in early August, and almost the first news that met me at New York was that the yellow fever situation in New Orleans was very serious and that many people had died of the disease, among them my old friend, Archbishop Chapelle. I was anxious to go down there as speedily as possible, but I found many things to attend to in Washington, so my departure was somewhat delayed. I had some work to do in Texas in regard to the Cotton Boll Weevil situation, and knew that if I went to New Orleans first, Texas quarantines would greatly postpone my entrance into that State. So I went to Texas first by way of St. Louis and the so-called Katy Railroad, and it must have been late in October or early in November before I arrived in New Orleans. By that time the emergency was past and the last case of yellow fever had been discovered. The city was recovering from its fright, and a feeling of great optimism prevailed. As I was registering at the St. Charles Hotel, I remarked cheerfully to the clerk, "Are there any mosquitoes about?" He said, "No, we killed the last one some time ago." Just at that moment unfortunately I looked at my left hand and there was an undoubted yellow fever mosquito quite ready to puncture me.

This reminds me of an interesting thing that occurred while I was still in Texas. I arrived at San Antonio late one night and went to my old hotel, the Menger, only to find that there was a big convention in town and that all of the rooms were occupied. The room clerk, an old acquaintance, said that he could give me a cot in a room with three other men. I accepted and went up with my luggage. As I was preparing for bed (there being no one else in the room at the time), I heard footsteps in the hall, the door opened and in came the other 


\section{FIGHTING THE INSECTS}

three men. I pulled out my hand lens, knelt on my cot and began to examine a spot on the wall.

"What are you doing?" said one of my roommates.

"I have just found a yellow fever mosquito," I said.

"My God!" said one of them, and they collected their luggage and left, leaving the whole room to me.

I spent a number of days in New Orleans, talking with Dr. White and going about with several of his able assistants (Dr. Rupert Blue, afterwards Surgeon-General of the Public Health Service, was one of them). I saw several demonstrations of fumigants, took a lot of photographs, and finally returned to Washington filled with enthusiasm over the wonderful results accomplished by Dr. White and his able assistants and the organizations of the prominent citizens of New Orleans. It was a magnificent demonstration of the value of the discovery of the mosquito carriage of the disease. The work carried on and based on this discovery undoubtedly saved thousands of lives, and established a fine confidence in the minds of almost everyone in our ability to prevent the disease in the future.

I was delighted when I was told by one or two of the leading citizens that they had made excellent use of my book on mosquitoes and their prevention and destruction, published four years before.

And now definitely to return to malaria: I visited the historic Roman Campagna for the first time in 1902, but I was in Italy for another purpose and did not meet the workers on malaria on this journey. I did, however, get an idea, and a very vivid one, of the comparative poverty of that region from the agricultural point of view, a natural consequence of generations of saturation by this disease.

Later, by reading Italian publications, and by the accounts [ 130$]$ 


\section{THE STORY OF AN ENTOMOLOGIST}

of Italian efforts published in other languages, I became thoroughly familiar with the great work that had been organized there, and in 1905 met some of the workers and talked with them.

It was not, however, until rgio that I had my first insight into the great economic importance of the results that had been accomplished under the auspices of the great Italian society for the study of malaria, supported, as it was, not only by government subsidy, but by a large sum from the privy purse of the King. I landed at Naples in early June, and in company with a very delightful young physician from Philadelphia, Dr. Vail, whom I had met on the steamer, went up to Rome and called on Dr. Angelo Celli at the Medical Department of the University of Rome. I had corresponded with Celli and had read his fine book on malaria in the English translation, and I knew the remarkable results of his experiments on the Campagna in the way of protecting the agricultural laborers, engaged in the harvest, by the screening of their huts, and the railway employees by the screening of the station buildings. This had always seemed to me a palliative only. I had always been and still am an advocate of Anopheles destruction. I may state incidentally that when the Rockefeller Institute financed Dr. C. C. Bass in his quininization work in Bolivar County, Mississippi, I suggested to Dr. Rose, then director of the Health Department of the Institute, that another county in the same State be selected, and that I be given the opportunity to control malaria there solely by Anopheles destruction. So when I met Celli that morning I told him about all this, and his instant reply was that his method of protection and quininization was much cheaper, and that mosquito control on the Campagna was entirely out of the question, largely on account of the enormous expense. Drainage operations were very difficult on account of the character of the 


\section{FIGHTING THE INSECTS}

soil-mainly volcanic tufa. As a matter of fact, however, extensive drainage operations had been carried out in this very region by the early Etruscans, as Celli himself had pointed out in his book.

The visit was a delightful one. Celli had to give a lecture, and he introduced me to Dr. Tiraboschi, an authority on fleas, who took us to his laboratory and talked Medical Entomology to us for an hour or two.

Before leaving us, Celli made an appointment to take us out into the historic regions of the Campagna on the following morning, which happened to be Sunday.

That was a great day. We took the train at an early hour and got off at one of the stations where the buildings had been protected during the early screening days and before the adoption of the universal quininization. Celli, who spoke French very well, and I were so interested in our talk that we barely succeeded in leaving the train before it started on again, and I left my camera in the railroad carriage. Dr. Vail, however, was with us and kept his presence of mind and also his camera, which was lucky, as he took some excellent snapshots in the course of the day. There was also with us Dr. Ivantcheff of Bulgaria, who had been the Health Officer of the Bulgarian troops in a recent outbreak in the Balkans and who had come on to Rome to study malaria.

The four of us walked about through the fields for the rest of the morning. What a contrast the Campagna offered to the scenes of eight years before! Then the aspect was comparatively desolate. The few inhabitants showed plainly the effects of chronic malaria, their faces emaciated, their eyes yellow, and the children with the characteristic pot-bellies, deroting enlarged spleens. But now in 1910, agriculture was flourishing. Although it was only June, they were already cutting the third crop of 


\section{THE STORY OF AN ENTOMOLOGIST}

lucern. Capital had come down from the north, and many barns and other agricultural buildings had been erected. We saw groups of people coming back from early Mass. The women were rosy-cheeked and vigorous, and the bright-eyed, active children clustered around Celli and begged for a story. Celli, by the way, was an obvious favorite with all of the peasants. They seemed to realize that he was largely the author of the vastly improved conditions. Dr. Vail photographed him talking to a group of the children, and from this photograph I made a lantern slide that $I$ have often used in public lectures since that day.

I wish that I had made notes of many of the interesting things that Celli said. However the impression of his delightful personality has remained with me ever since. Knowing of Ross's very decided opinion concerning the Italian School and of his more vigorous denunciation of their methods, I asked Celli rather jocularly about "our mutual friend Ross." He smiled amiably and said that he and Ross were very good friends, and that he had contributed a chapter on the malarial situation in Italy for Ross's big book on malaria that had just been or was about to be published in London. I told him that I also had contributed a chapter to that work, and that in it I had described the anti-malarial measures begun in the United States.

We walked until one o'clock, interviewing peasants, taking photographs, and examining the few irrigating ditches, where I had no difficulty in finding active anopheles larva. Thus we crossed from the railway over a good stretch of land to a tramway to the east and then to a wayside inn where we had a very excellent luncheon. And then we found that the tramcars did not run on Sunday. We were ten or twelve miles from Rome, and the day was hot. Celli proved himself a man of resource and asked the proprietor of the little inn about a 


\section{FIGHTING THE INSECTS}

vehicle of some kind. There was nothing to be had except a big two-wheeled haycart without springs and drawn by a single horse. The innkeeper, however, was a very agreeable man, and he evidently had a great admiration for Celli. He placed four chairs in the cart, and we jolted into Rome along the famous but badly conditioned Appian Way. Celli called it "our triumphal procession into Rome."

That was the last time I ever saw Celli except that he came down to the train to see me off for France the next morning. He died a year or so later. He was a wonderful man, and Italy owes him much.

I have said that I left my camera on the train on Sunday morning. We telegraphed ahead, notifying the conductor, and asked him to leave the camera at the station in Rome, but on the following morning it had not arrived and I went on to Marseilles without it. Celli promised to get it for me and forward it to the American Express Company at Marseilles. I waited for it there four or five days, and then, having to go on to Spain and Portugal, bought a new camera. I remember with great chagrin that I did not learn in the shop exactly how to operate it, with the result that some very interesting snapshots I took in Spain and Portugal were flat failures. It may be of interest to state that when I arrived in Paris some weeks later I found my camera at the American Express Company, where it had been forwarded from Marseilles, and I had to pay what seemed to me a very large sum in the way of customs' duty and forwarding charges. The only photographic record of this very interesting journey consists, therefore, in the excellent photographs taken by Dr. Vail in Italy.

On the afternoon before our expedition to the Campagna, and after our visit to Dr. Tiraboschi, I called at the laboratory of the famous Battista Grassi. I found him to be a short stocky 


\section{THE STORY OF AN ENTOMOLOGIST}

man, with his hair en brosse, German fashion. In fact his atmosphere was distinctly German, and I learned later that he had studied in Germany and had married a German girl. Finding that I could not speak Italian very well, he refused to speak French, and our talk was wholly in German. He also declined to talk with me about mosquitoes and malaria, but insisted on discussing in preference the Aphidids of the genus Phylloxera, a subject in which he was then interested. Although I had assisted Riley and Monell in editing their paper on the insects of this group, I was not especially interested in the subject, and left Grassi in a rather disappointed frame of mind.

But things changed. The Great War came and Germany was defeated, and when I visited Italy in 1920, Silvestri of Portici, happening to be in Rome when I was there, and happening also to be a friend and admirer of Grassi, brought him down to the Quirinal Hotel to talk. What a change! Grassi, who had in the meantime been made a senator of the Italian kingdom, according to the commendable custom they have in Italy of rewarding men of prominence, was no longer German. He spoke French fluently and with all the suave manners of a Frenchman. Moreover, he had already begun large-scale experiments at Fumacino, south of Rome, in the way of malarial control, and he had adopted Celli's manners and methods with the peasants. I must confess that these people had apparently taken him into their hearts and had become convinced that he was their friend and was laboring for their good.

In 1923 I visited Rome again and went with Grassi down to Fumacino, where he staged a demonstration of his method of fumigating stables. He showed me a shallow lake into which he was thinking of introducing Gambusia, and also a school in which the pupils were being told the necessary facts about malaria. Furthermore, he told me how he had finally been able 


\section{FIGHTING THE INSECTS}

to discover the mating habits of Anopheles. It was at a pigsty, and just before dusk the males came swarming out and hovered about, waiting for the females. Then they coupled with them during flight and soon disappeared. We drove back to Rome just at dusk, stopping at a temporary laboratory, where I had the pleasure of meeting Signor Negri, then one of Grassi's principal assistants. Grassi talked much to me about his own claims to be acknowledged as the real discoverer of the transfer of human malaria by Anopheles. He said that Ross had anticipated him only in the discovery of bird malaria, since Ross had studied first the malaria of the sparrow in Calcutta. Ross had already received the Nobel Prize, and Grassi was very indignant. He told me that some German writer had taken his side, and that he had written a long paper on the subject. He wished to have me translate this into English and have it published in the United States. But he never sent it to me, and I hardly believe that I would have done it in any event, since I think that the fame that came to Ross was justified.

One interesting little incident of our auto journey from Fumacino back to Rome should be told. We were passing a peasants' house in the middle of a cultivated field, where a man and his wife were working. The automobile stopped and the Senator called out, "Ho, Giuseppe!" The man dropped his hoe, but, instead of coming down to the road to see us, he went off into the house, while his wife came down to the gate, smiling a cordial welcome. There was a little talk in Italian, and while I was thinking that the man had purposely avoided us, he came out of the house with a bottle of wine in one hand and three eggs in the other. Knowing that the Senator did not drink, he offered me the wine, and insisted that Grassi should take the eggs. I took a drink, and Grassi, after protesting, put the eggs carefully into his pocket, and then he said to me, "Giuseppe, 


\section{THE STORY OF AN ENTOMOLOGIST}

here, is a great anarchist," and then to Giuseppe, "This gentleman is an American." Whereupon I remarked, "Yes, and we have no anarchists in America." To which Giuseppe instantly replied, "You are mistaken. I have a cousin who lives in Chicago, and he is a much more pronounced anarchist than I am." This staggered me so that I made no reply, and we went on into Rome. The Senator explained on the way that the previous winter Giuseppe had stabbed a man in a fight and had been put in prison. He himself had supported the wife during this time and eventually had had Giuseppe released. The gift of the three eggs was from gratitude, and it was repeated every time the Senator passed the house on his way to Fumacino.

That was the last time I saw Grassi. He had aged greatly since 1910, and had lost the sight of one of his eyes. Before I stop these anecdotes about him, I must mention the fact that on one of my visits I was the first to inform him of Sambon's theory that Pellagra is carried by Simulium. He characterized this as nonsense and said that he knew many cases in Italy where there was Pellagra and where Simulium did not exist.

Again, on a later visit, I asked him about the efficacy of bats as devourers of malaria mosquitoes, and of the project that an engineer officer of the Italian Army had advanced (after visiting San Antonio, Texas, during the war, and making the acquaintance of Dr. A. R. Campbell) of erecting bat roosts on the Campagna. He replied that Mussolini had asked him for his opinion and that he had replied that it was nonsense. He told him further that he knew many very bad malarial localities in Italy where bats were most numerous.

Grassi was perhaps one of the best-informed general zoölogists in Italy, and did a great deal of admirable work. He died, I think, in 1924. Since his death the Rockefeller Foundation of 


\section{FIGHTING THE INSECTS}

New York has stationed an admirable man, Dr. L. W. Hackett, in Rome, where he is conducting a great work against malaria.

It seems strange that the possible usefulness of economic entomology in the World War was not at once appreciated. I am not sure, but I think that the English realized the value of professional entomological knowledge before any of the other battling nations. I remember that Mr. R. A. Peocock, a very competent man, although not known as an applied entomologist, went over to France at an early date to assist the men who were studying trench fever. Later other excellent men were commissioned by the English government and sent to different points. For example, H. Maxwell-Lefroy was sent to Mesopotamia. At a comparatively early date, Professor (afterwards Sir) Arthur Shipley wrote a book entitled "The Minor Horrors of the War," and followed it with another entitled "More Minor Horrors." When the relationship between typhus and trench fever was established and the body louse was thoroughly accepted as the transmitting agent, the Germans began an intensive study of this insect. A large book was prepared by Dr. A. Haase, whose investigations had been carried on in a camp of Russian prisoners.

The United States government was much slower in accepting the offers of numerous trained economic entomologists who were anxious to be of service. Some enlisted in the ranks, and their valuable knowledge was not used. It seemed to some of us that in certain respects it was unfortunate that Dr. Gorgas should have been the Surgeon-General of the Army, for he seemed indifferent as to malarial probabilities-for example, in his selection of many of the great concentration camp sites. A number of these were placed at points where mosquitoes, including Anopheles, were notoriously abundant. I imagine that it was his success in insect control in Panama that brought about this apparent indifference. When our country was getting ready, I 


\section{THE STORY OF AN ENTOMOLOGIST}

wrote him that there were many men, well trained in applied entomology, who could be used to advantage and who were anxious for service. Possibly he never saw my letter, but I received a reply from his office, signed by one of his assistants, stating that what they needed was men trained in sanitary engineering, such as they had employed at Panama, but that they did not need entomologists-men "trained to count the spots on a mosquito's wing." This seemed stupidly absurd to me, since it was perfectly obvious to a clear mind that as soon as a disease is discovered to be carried by an insect, almost the first man to be called in is the man who has been trained in insect life and the best ways of controlling it. Later, however, there was something of a change. Van Dine and Herms were commissioned and well placed in two of the big camps near San Antonio. Middleton, although not commissioned, was used in the same capacity in a more northern camp. And there were others, although I do not recall their names. At the close of the war, Van Dine was sent to New York to assist in the delousing of the returning troops, and Hutchinson did elaborate work with the housefly and the body louse both at Washington and at New Orleans. So far as I know, no entomologists were sent to France on account of their entomological knowledge, but many did go as private soldiers. A notable example was H. L. Parker, who rose to a captaincy. Still later he got a Doctorate from the University of Paris, and is at this time in charge of the U. S. European Parasite Laboratory at Hyères.

Much of this I summed up, together with many other instances in which the entomologists helped during those strenuous times in an article entitled "Entomology and the War," published in the Scientific Monthly. ${ }^{1}$

\footnotetext{
${ }^{1}$ Volume 8, No. 2, pp. I09-II7, Feb. 1919. Reprinted in the Smithsonian Annual Report for 1919, pp. 411-419, 1921 .
} 


\section{FIGHTING THE INSECTS}

Writing of the strenuous days of nineteen sixteen to eighteen naturally reminds me that food contamination by the housefly in concentration camps and wherever great bodies of men are brought together is a subject upon which we have not touched. I began to study the housefly carefully as early as I 896 . I published a special bulletin about it a little later, and, as shown in a previous chapter, went thoroughly into the question of food contamination by flies coming from human excreta. I like to think that my investigations and publications helped to start the widespread housefly crusade in the early part of the century. Surely a book that I published in IgII under the title "The Housefly-Disease Carrier" ${ }^{1}$ lent a boost to the crusade. It is true that typhoid inoculation was brought forward only a few years later, and that by it the importance of the housefly as a typhoid carrier was greatly lessened. But the pestiferous little creature carries other diseases beside typhoid, and, by the aid of boards of health and citizens' committees, the crusade was continued with excellent effect. It is true that the gradual disappearance of horses in large cities, because of the extraordinary development of the automobile industry, has been responsible for the great reduction in the number of flies in cities, since the housefly used to breed principally in horse manure. But the crusade was an admirable one, and I am very glad to have taken part in it. The United States really led the way in this direction, although England took it up shortly after and excellent work was done in London. Other countries followed. My book was translated into Russian, Hungarian and Spanish; and I learn that since the war intensive anti-housefly work has been begun in Italy. My dear friend, Dr. Jablonowski of Budapest, began to translate the book as soon as he received it, and he

1 Frederick A. Stokes \& Co. New York. 


\section{THE STORY OF AN ENTOMOLOGIST}

brought his manuscript with him to the Entomological Congress at Oxford in 1912 for me to read. The World War, however, came on so soon thereafter that his translation was not published until 19r7. He has recently written me that it was used as a reader in the public schools, and that very dilapidated copies are still to be seen in the school libraries.

Why did the world endure the housefly so long? I remember a meeting of the American Civic Association in Washington. Dr. Woods Hutchinson of New York talked to the meeting about the housefly. He said very bad things about it and commended the Association on its strenuous efforts to promote the warfare against it. At the conclusion of his lecture, a dear old lady arose in the audience and said, with breathless indignation, "In the name of the women of the United States and of that of the Society for the Prevention of Cruelty to Animals, I protest against the wholesale murder of these defenseless creatures." Perhaps that was one of the reasons.

But I must not leave the subject of the housefly without telling one more story. In the early autumn of 1912 an international congress of hygiene and demography was held at Washington and was attended by many eminent sanitarians from all parts of the world. There was a section on the Zoölogical Aspects of Sanitation, presided over by the late Dr. Herman P. Biggs-at that time, I think, Chairman of the Board of Health of the City of New York, and a very eminent man. I had known him when he was a little boy at Trumansburg, New York, and I think that I was the first one to interest him in natural history studies. My house guest at the time was Dr. George H. F. Nuttall, a famous parasitologist and head of the Quick Laboratory of Cambridge University, England. We went together to this zoölogical section. Dr. Mesnil of the Institut Pasteur at Paris was to have been the principal speaker, but for some 


\section{FIGHTING THE INSECTS}

reason he did not attend. I was asked to make the opening address. In deference to Mesnil, I spoke especially of the admirable work done by the Pasteur Institute, instancing particularly the fundamental discovery of the malarial organism by Laveran; also the work of Marchoux and Salimbeni against Yellow Fever in Rio di Janeiro and of that of the brothers Sergent on Malaria in Algeria. I spoke more or less historically and wound up with some rather extensive remarks about the housefly, as I had at that time only recently published my book on this insect. Dr. Nuttall was the next speaker, and in the intensive discussion that followed, the housefly was almost the only creature mentioned. The last to speak was Dr. C. V. Chapin, the health authority of Rhode Island, who rather threw cold water on the importance of the housefly by stating that its importance as a carrier of typhoid in well-sanitated cities was by no means proved, and that we should have more laboratory demonstrations. He further stated that a close mathematical study of the spread of typhoid in cities should be made on the same general lines as the mathematical studies on the spread of malaria by Sir Ronald Ross.

I was called upon to close the discussion, and I at once tried to overcome the impression made by Dr. Chapin. I instanced Washington as a well-sanitated city in which there could be no doubt as to the importance of the housefly in the spread of typhoid. I called attention to the human excrement deposited in alley-ways during the hot summer nights in Washington, and of the swarming upon these excreta by houseflies in the immediate neighborhood of the open windows of kitchens and dining-rooms, especially in the lower portions of the city. I showed that it had been proved that a definite per cent, say five, of persons who had recovered from typhoid were chronic carriers, and that therefore a certain definite proportion of these 


\section{THE STORY OF AN ENTOMOLOGIST}

excreta were dangerous. Further that typhoid must be carried frequently to food supplies by the flies that swarmed upon these droppings. I made it as strong as I could.

To my surprise, Dr. Biggs asked Dr. Nuttall if he had anything more to say. Nuttall got up in his quiet way and said, as I remember it, "I have studied the housefly and its bacterial flora and content taken in the classrooms at Cambridge and in the college bakehouses and have isolated typhoid organisms from all of them. After these studies, which have been prolonged, I consider that a single contaminated housefly is a greater source of danger than many gallons of polluted water. What we need in considering this question is not mathematics but common sense!"

This finished the discussion, and I feel sure that the impression made upon the minds of the large audience was not the one desired by Dr. Chapin. I have often told this story since in lectures, and once, I remember, at one of Graham Bell's Wednesday Evenings, when Dr. Simmons, long-time secretary of the American Medical Association, and other medical men, were present. I am sure that Nuttall's words have had due weight in the minds of many important men.

In fact, they often come up in my mind when I am reading some of the rather laborious and possibly far-fetched adaptations of mathematics to other branches of biological science. 


\section{Chapter VII}

\section{$\mathrm{R}$}

UNNing back for nearly two hundred years, every once in a while some one has been filled with the idea that silk culture would prosper in the United States. I seem to remember that colonists in South Carolina began it. Down to the present time it has never amounted to anything. The so-called Morus multicautis craze in the 1830 's resulted in the planting of thousands of mulberry trees and in the starting of exaggerated ideas on the part of many people, especially, perhaps, in the state of Connecticut, with the result that many small fortunes were lost.

When I came to Washington in November, 1878, Professor Riley had a good stock of silkworm eggs of a race that he had been trying to develop in Missouri and that fed upon the leaves of the Osage orange (Maclura aurantiaca). The following spring these eggs hatched, and I saw the domestic silkworm for the first time. Riley had written an article about silkworms in one of his latest Missouri reports, and following the directions in this article I fed the worms to full growth, when they spun their cocoons from which later the moths issued and laid a new lot of eggs. Some of the high officials in the Department of Agriculture were interested, and we did the same thing again the following year. 


\section{THE STORY OF AN ENTOMOLOGIST}

In the meantime Riley resigned in the spring of 1879 , and Professor Comstock was put in his place. Before leaving the Department, however, Riley had me write a manual of silk culture, which was published over his signature before he left.

Riley returned to the Department in I88I, and after a year or two took up the subject of silk culture rather vigorously. He realized that the success of the industry in this country would depend largely on our ability economically to reel the cocoons, and he had heard of an electric reel invented by General Serrell, an American then living in France. He was fortunately able to secure the services of Philip Walker, a nephew of General Serrell's, a young man of much ability and charm. He brought him to Washington, established a Serrell reel, sent out silkworm eggs to correspondents, and helped two or three local associations interested in the matter, notably a California organization, one in Louisiana, and a rather pretentious "Women's Silk Culture Association" that had its headquarters for some time in Philadelphia. Congress made small special appropriations for this work, which were repeated for several years.

At the expiration of this time Mr. Walker became convinced that the industry could not succeed in the absence of an import duty on raw silk, and he stated this frankly to committees of the House of Representatives.

At that time the McKinley Tariff Bill was being prepared in the House, and a ten per cent duty on raw silk was proposed. This was naturally strongly opposed by the Silk Manufacturers' Association and failed, and the matter of silk culture was dropped by the government for the time being.

In 1898 James Wilson of Iowa was appointed Secretary of Agriculture. He had been prominently connected with the Iowa State Agricultural College and Experiment Station and had also been a member of Congress. Very justly wishing to familiarize 


\section{FIGHTING THE INSECTS}

himself with the different aspects of agriculture over the country, he travelled extensively, and was much struck by the conditions that existed in the Southern States. He realized the defects of the one-crop system that then prevailed and thought much about the possibility of introducing household industries that would help. He thought of poultry, bee culture, and silk culture, and when he returned to Washington he consulted me about the latter project. We had already started bee culture work on an intelligent basis under Frank Benton, and I argued the silk matter with the secretary. He was quite firm in his opinion that it should be tried again. The white mulberry, he said, is widely distributed in the United States, and the Osage orange is largely grown both as a hedge plant and as a windbreak in the Far West. He felt sure that the reeling difficulty could be overcome. I assured him that the difficulty was so great that with the machinery then existing it would be impossible profitably to reel cocoons here on a large scale, even if the cocoons were presented gratuitously to the reeling establishments. $\mathrm{He}$, however, did not believe this, and asked Congress for a small appropriation (ten thousand dollars, I think).

We decided to buy healthy eggs in quantity from one of the reliable Italian dealers, to distribute them gratuitously to all correspondents who wished to raise cocoons, and to accompany each shipment with The Silk Culture Manual, which had been revised by Walker and republished. Then the plan was to set up a small reeling establishment in Washington, to buy the cocoons from our correspondents at standard European prices, and to reel them, selling the resulting raw silk to American manufacturers.

This seemed a very logical plan, and it was carried out.

About this time a very competent lady of Charleston, South Carolina, Miss Henrietta Aiken Kelly, who had been the head 


\section{THE STORY OF AN ENTOMOLOGIST}

of a large and fashionable young woman's school in that city, had, through a recent long stay in Italy, become much interested in silk culture as a household side-industry. She corresponded with us, and, convinced of her ability, I got her to write a new manual of silk culture. And then I went to Europe to study the industry, to buy eggs and reeling machinery, and to engage expert reelers.

I looked up the reels first, and finally, going to Lyons, a great center for that sort of thing, I bought, with the help of the American consul, Mr. Covert (a cousin or nephew of Ezra Cornell), the very latest thing in the shape of a three-basin reel. After much trouble, Mr. Covert, who was courtesy and helpfulness personified, succeeded in finding a mother and her daughter, both expert reelers, who would come to America. It was a great undertaking for these two French women, and they made many stipulations, among them the very natural one that in case of illness or death they should be returned to France at the expense of the United States government.

The matter of the reel once settled, I went to the South of France and then on to Italy, studying in both countries the way the peasants raised the silkworms in their own homes, the methods of the buyers of cocoons, and the conduct of the bacchicultural laboratories for the safeguarding of the eggs against the causative micro-organisms of pébrine.

It was during this visit to Italy that I first met a certain Duke and Duchess. The Duchess was American by birth. Their large estate was in northern Italy, and practically all the peasants on the estate raised silkworms. In a near-by town was a large establishment from which I arranged to buy eggs for our government. Thus the place was admirably adapted to my mission in every way. There were large plantations of mulberry trees of different ages, and not only did every peasant's home contain the 


\section{FIGHTING THE INSECTS}

trays for rearing the worms, but the attic of the old castle was turned into a rather large scale rearing establishment.

I spent one of the pleasantest and most profitable ten days in my life in August, 1902, with these fine people at the old castle which stands on the summit of a hill looking north over a wonderful valley. Fortunately, while I was there the cocoonbuyers made their annual visit and into the courtyard of the old castle came the peasants from the estate, men and women each with huge hampers of cocoons upon their shoulders, and the children tagging along to see the fun. The cocoon-buyers set up their scales in the courtyard, and each wicker hamper was weighed with and without its cocoons. The peasants were intensely interested in the weighing process, and in each case the weighing machine was surrounded by a struggling and expostulating crowd. Not only did the peasants from the estate bring out their hampers, but the servants in the castle did the same. I remember that the cook came out in his white cap and apron, with a huge and well-filled hamper on his shoulders. I imagine that the trays in the attic must have been used by these house servants.

But the silk culture aspects of this stay at the old estate were by no means the most interesting. I was intensely interested in the Duke and the Duchess and in their mode of life. Afterwards I became very much attached to them, and I visited them frequently in later years. In fact, after the Great War they came to America on a visit and spent some time with Mrs. Howard and me in Washington.

Although this first visit was made almost wholly for the purpose of looking up silk cultural matters, this is a good place to say something about my hosts. During only one of my visits were there other guests, and usually the three of us used 


\section{THE STORY OF AN ENTOMOLOGIST}

to sit at the dinner table until after midnight, talking of all sorts of things.

Although the Duke was the most democratic of men, he could not get away from the fact that he was the head of three old ducal families. It is true that after his return to Italy he had broken with the middle-men who ran the estate, and that the peasants at his suggestion had organized themselves into a managing body, electing their own headman from among their own number and consulting together about the management of the smaller details. This act in itself had made the Duke lose favor with the middle-men, who virtually controlled most of the great estates, and to a certain extent with the proprietors themselves; while through a novel that he wrote some time later he made himself unpopular with the Catholic Church. In fact, he told me once that he was the most unpopular man in Italy. I got him to write up his agrarian experiment and had it published for him in an American review.

In spite of his democracy, as I have hinted, he could not get away from many of the old feudal ideas. The peasants on the estate were for the most part descendants of the retainers of his ancestors, as was shown in many ways that were strange to me as an American. For example, one morning after breakfast the peasant who happened at the time to be the president of their organization called to ask the Duke's consent to the marriage of two of the young peasants.

I shall never forget those long evenings when the dear people told me about themselves-in fact, gave me the history of their lives. I made no attempt to respond in like fashion, since my own story had been so commonplace. Here in a brief and bald way is what they told me.

As a girl, the Duchess had been small and beautiful and blond. She was born and had spent her girlhood in one of the Southern

$$
\text { [ I49] }
$$




\section{FIGHTING THE INSECTS}

States. She was an adventurous youngster, and the home town, charming as it was, rather irked her. She finally induced her parents to send her to Boston to study singing. When she got there she soon found that her voice was not worth while, and in some way she got a job on a newspaper. I believe that she did not inform her parents. But Boston did not satisfy her, either, and she induced the managing editor of her paper (she had proved herself a clever writer) to send her to England to write up a certain angle of a rather important affair that was transpiring at that time. On the steamer, going over, she met a wellto-do young Englishman who married her soon after their arrival in London.

Of course this is all sketchy. I am telling only the bare facts.

Her husband caught a bad cold, and tuberculosis developed. They went to the Enghadine, where he died of what we used to call quick consumption. She was broken-hearted and returned to the Enghadine year after year to do what she could for any of the tuberculous young English people who used to go there. Her husband had left her well-to-do.

The Duke's father was an ardent Italian patriot, a friend of Cavour and of Victor Emmanuel and, of course, of Garibaldi. But he died when his son was a little child. When the boy had reached a certain age (twelve or thirteen or perhaps fourteen) he found out certain things that distressed him extremely, and in his despair he ran away from home (taking with him, fortunately, papers to prove his identity). He got down to Naples and boarded a vessel bound for the Argentine. On reaching Buenos Aires, he did all sorts of work to support himself, even menial things. As he grew to manhood, he got a job as a vaquero on a large cattle ranch owned or managed by an Italian. Here he had all sorts of adventures and had many accidents. He told me that almost every bone in his body had been broken at 


\section{THE STORY OF AN ENTOMOLOGIST}

one time or another, and he had adventures with the Indians that were well worth telling.

He had told the ranchero his history, and it happened that on a certain visit that the latter made to Buenos Aires he noticed in a newspaper printed in the Italian language an advertisement asking for the wherebouts of the young man, with the further statement that a certain firm of attorneys in Buenos Aires wished news of him and had information for him that would be to his advantage. On his return to the ranch, the ranchero showed the boy the newspaper. They talked it over, and the upshot was that the young Italian went to the city, learned that his mother had died, proved his identity, and started for home.

But he did not go directly to Italy. The spirit of adventure and the itch for travel were too strong. He went out to the Philippines (years before the American occupation), and then he went to the United States and stayed there many months and of course learned English, a language which he spoke and wrote with great fluency for the rest of his life.

Eventually he returned to Italy, assumed his titie and claimed his estates. He found himself a wealthy and much sought-after man-in fact, a great match. He married and in course of time his wife presented him with two daughters. And then they had trouble and she left him. He was hurt beyond measure. Nothing seemed worth while any more. Life was not worth living, and he took no care of his health. His physical and mental situation became desperate. With difficulty his friends induced him to consult a famous physician, who advised the outdoors and sent him to the Enghadine. He went to a certain hotel that had been recommended to him, and from there as headquarters he took long tramps, sometimes lasting several days.

$\mathrm{He}$ had been told that he could have his rooms at the hotel only until such time as some one who was described as "The 


\section{FIGHTING THE INSECTS}

Little Sister" should arrive, and that she was expected in two or three weeks.

One night on his return from a two days' tramp he entered the dining-hall of his hotel and found that most of the guests were greatly interested by the presence of a new face, that of a charming, vivacious little golden-haired woman. It was "The Little Sister." The Duke was introduced, they became fast friends, and eventually they fell in love.

But the Duke was married, and he was a Catholic. Italy was Catholic, and there were no divorce laws even in such obvious cases as his. And so the lovers lived on, puzzling their brains for some solution to their difficulties. And this lasted for seven years.

Then the Duke, through an old relative, made a discovery. He learned that his father, who, as we have seen, was an ardent Italian patriot, did not wish his son (he expected a son, of course) to be born a subject of Austria. And so, when he found that his wife was about to give birth to their first child, he carried her off to Paris, and there the baby was born.

I don't see what difference that made, but it seemed to straighten out the legal difficulties, and the Duke got a French divorce and then married "The Little Sister."

After a time they went back to Italy and to the old castle, and the peasants organized a great fête, with a triumphal arch. It is an interesting story, isn't it?

To get back to silk culture. Quite as I expected, although I tried hard for success, the silk culture work under Secretary Wilson turned out to be an economic failure. We distributed quantities of certified eggs to many people in many parts of the country. Some of them who were Europeans with a thorough knowledge of silk culture, and others who were aided by our 


\section{THE STORY OF AN ENTOMOLOGIST}

manual of instruction, raised excellent cocoons and sent them to Washington in bulk. We paid them the current European price, and then we reeled the cocoons.

We soon found that our correspondents would not continue to raise cocoons at the rates we were paying, and we also found that when we sold the reeled silk we did not receive enough even to warrant the prices we had paid for the cocoons. So the experiment was abandoned.

Therefore, for many years, I took it that we had fairly well proved that we can not produce in the United States reeled silk that in price will compete with the silk received from Japan and China, where labor is so cheap.

At the San Francisco World's Fair in 1915, a new type of silk reel was exhibited. A very clever chemist, Guy Wilkinson, who had made a large sum of money through some invention, became interested once more in the possibilities of silk culture in America. He bought a place in Northern California that he named Serriterre-not far from Chico. He found a Swiss Italian who had new ideas about planting mulberry as a hedge surrounding arable fields, thus occupying little land space. He also got the Weber-Vitali reel from San Francisco and engaged the expert Italian reeler who had been sent over to the Exposition with it. He raised very excellent cocoons, and his experiment was rather a promising one. But eventually it failed, and I think he died.

There have been other attempts since on a larger or smaller scale, but all have failed except one. That one is now being carried on with large capital and on new principles at Ensenada, some miles northeast of San Diego, California. Its promoters have studied carefully and scientifically every aspect of the industry in Southern Europe, and they have combined practically all of the features of the silk industry into one institution. In 


\section{FIGHTING THE INSECTS}

other words, they are making or are planning to make silk stockings and perhaps other silken things, and are raising their own silk with which to make them. I have visited this place twice and have been much impressed by the confidence, ability and intimate knowledge of its manager, but naturally I am making no prophecies. 


\section{Chapter VIII}

$\mathrm{T}$

HE Entomological Service at Washington grew rather wonderfully. Prior to, say, I89o, it was considered a necessary service but one that needed financially rather small support. Nevertheless, I do not wish to underestimate the results accomplished with small funds and a limited number of workers. We economic entomologists did some big things and laid the bases for much bigger things. What we did attracted the attention of practical men, and demands came from them to legislative bodies to spend more money on the work.

And then came in comparatively rapid succession the series of events that we have already referred to, and that helped to focus the attention of the world and especially, perhaps, the people of the United States, on the subject of economic entomology. Not since the Grapevine Phylloxera days in the late I860's and I870's had there been so much excitement caused as by the discovery of the San José scale in eastern United States orchards in 1892 , and the subsequent embargo of practically all of the countries of the world against American fruit that was started by a German proclamation in 1898 . Then, too, the Gipsy Moth had been discovered in America only two or three years earlier, and in 1894 we became distressingly conscious of the 


\section{FIGHTING THE INSECTS}

fact that the Mexican Cotton Boll Weevil had crossed the Rio Grande and was a threatening factor in the production of cotton in Texas and potentially in the whole Cotton Belt. To cap the climax, an English surgeon in the Indian medical service, Major (afterwards Sir) Ronald Ross, discovered in 1898 that the mosquitoes of a certain genus (Anopheles) were the sole transmitters of malaria.

Is it any wonder that people began to appreciate the importance of insects as dangerous enemies to mankind, and that Congress and the state legislatures began to appropriate more money for the study of these enemies?

Nevertheless, when we view the situation from our present standpoint, the action of the world as a whole seems rather slow. The best trained men in the university laboratories continued their intensive work on non-economic creatures, and practically only in the agricultural colleges were studies of injurious insects carried on. But in these colleges and in the state agricultural experiment stations and in the Federal Bureau of Entomology at Washington there was an almost immediate response. More and more men were trained. More and more bright young men were attracted to the subject as a means of livelihood, and this was encouraged by larger appropriations from legislative bodies.

So the federal organization of which I happened more or less accidentally to be chief assumed a new importance. Appropriations began to jump. The service took on a Bureau rank. More and more men were taken in. Soon our investigations began necessarily to spread into other countries. The obvious reason for this was that nearly two-thirds (reckoned by species) of our first class insect enemies-that is, those insects that damage us to the extent of hundreds of thousands of dollars annually -were of foreign origin. 


\section{THE STORY OF AN ENTOMOLOGIST}

The rate of growth of the service may be expressed concretely by the statement that, whereas the annual federal appropriation for this purpose in 1894 was about thirty thousand dollars, in 1927, when I retired, it approximated three million dollars. Another striking change in the public attitude that I have already pointed out in another book is the fact that in 1876 the Federal Congress, after a discussion lasting many months, finally passed a bill appropriating eighteen thousand dollars to be expended by a commission of three men (none of them connected with the United States Department of Agriculture) for the investigation of the Rocky Mountain Locust or Colorado Grasshopper. And this was done only after a long delay and after the reduction of the sum from twenty-five thousand dollars and of the number of members of the commission from five to three. Whereas in 1929 the Congress (both House and Senate), after a delay of only a few hours, appropriated four million two hundred and fifty thousand dollars to be spent by the Department of Agriculture in an effort to exterminate the Mediterranean Fruit Fly in Florida.

What shall be said about the years that intervened between I894 and the present time? Obviously, there was great activity; obviously, the problems were very great; and obviously, the labors of the entomologists must have been to some degree successful in order to justify the confidence implied by the extraordinary increase in funds. The whole period is filled with memories of successes and failures, of more or less dramatic incidents, of wide contacts with remarkable personalities. But it is not an individual history. As chief of the federal service, my own life was not what it might seem to an imaginative person. I stuck steadily to a certain amount of research. Dr. B. T. Galloway, when Assistant Secretary of Agriculture, once said that I was the only Chief of Bureau to do this. I could not help it: my 


\section{FIGHTING THE INSECTS}

interest in insects was so great. But my individual work was petty compared with the work of many men in the Bureau and in the state organizations.

Think of a young man not long from an agricultural college, sent suddenly to start a camp laboratory, with a half dozen assistants and plenty of supplies, on one of the vast Arizona cattle ranges, to investigate the ravenous and extremely injurious Range Caterpillar. Think of Dr. Hunter, educated at the University of Nebraska and teaching temporarily at the Agricultural College of Iowa, sent down to southern Texas to begin work on the Cotton Boll Weevil and to study a great crop with which he was previously unfamiliar. And yet Wildermuth was entirely successful in Arizona, and Dr. Hunter not only became an authority on everything connected with cotton and pointed out at an early date to the Southern planters a perfectly competent way to grow cotton successfully in spite of the Weevil, but gained the affection and respect of the whole South. Think of the dozens of young men sent to foreign countries, to nearly all of the countries of Europe, to Japan, to China and to India, to Central America, to South America, to Australia and to other parts of the world, a few of them linguists and others furnished only with a keen desire for success, great resource and indomitable perseverance. How I wish that the stories of some of these men could be collected and published!

The foreign search for parasites unquestionably appeals to the imagination more than the work done in our own country. It involves to an extreme qualities on the part of the workers that are not called upon to the same extent in work at home. I have allowed myself to tell stories about two of these men in "The Insect Menace." I should like to repeat them here, but haven't the space. In the home work-that is to say, in the United Statesthe sense of adventure is naturally not so great, yet there is 


\section{THE STORY OF AN ENTOMOLOGIST}

plenty of adventure of a kind in the work, for example, which was carried on in the great northwestern forests against the Pine Bark Beetles.

I early hit upon the idea that it was important for the chief of the service to visit his outlying stations as early and as often as possible, and these field stations, beginning with 1898 , became very numerous. The value of these visits was partly psychological. The man working alone or with only one or two assistants, in a far-away region, away from scientific societies and scientific companionship, and confronting the most difficult problems, is likely to grow discouraged at times. In such cases a short visit from the chief of the service is very encouraging, especially if the chief sees, as he always does, many things that bring forth complimentary words. If the worker is patted on the back and told that he is doing admirably, he goes at the work more cheerfully and in a much more hopeful spirit.

I remember one very marked instance of this sort of thing. A minute Thrips was playing havoc with the pear orchards in the Santa Clara Valley in California. A field laboratory was started and Dudley Moulton, a promising entomologist (now Commissioner of Agriculture for the state of California), was placed in charge. After some months' work of an intensive sort, in which he showed great intelligence and resource, the problem still promised no solution. The fruit-growers were becoming desperate. Some of the most prominent were threatening to cut down their orchards and sell their land for city lots or for some other purpose. About this time I dropped in on Mr. Moulton, praised him for the admirable work he had done, and confidently prophesied ultimate success. He told me afterward that this did him no end of good. He went at his work with renewed energy and in a few months the end came. He showed the 


\section{FIGHTING THE INSECTS}

fruit-growers how to handle the Thrips, the danger vanished and a great industry took on a new lease of life.

And there is a second psychological point connected with such field visits. As I have shown in an earlier chapter, it was the routine of the Agricultural Committee of the House (then in charge of the preparation of the Agricultural Appropriation Bill-this work is now being done by the Committee on Appropriations) to call the bureau chiefs of the department in early December to explain the need for estimates that had been sent in. This is the psychological point: if I could explain to the Committee that a month or two months before I had visited the field laboratory engaged in a certain investigation and had seen the whole situation, the Committee at once realized that I knew what I was talking about, and, since I am an honestlooking man, they accepted my word. But if I had been able to state only that So-and-so had told me of the need, there might have been some doubt in the minds of the Committee.

So I took many of these field trips, down through the South to study Boll Weevil conditions and laboratories; into Florida to visit the laboratory where citrus pests were being studied; out to California, up to Washington, east to Idaho where as early as 1898 C. B. Simpson was working on the Codling Moth; further east to the Bitter Root Valley, where we were working on the Spotted Fever Tick; down to Kansas, where E. G. Kelly and afterwards J. R. Horton were engaged with the grain insect problems; further east to Indiana, to visit J. J. Davis (who later left the service and is now a professor in Purdue University), and then out into New England to watch the intensive work that went on for many years against the Gipsy Moth and the Brown-tail Moth.

This doesn't sound very adventurous or at all dramatic, for none of us ever got into what are called "the wilds" (except 


\section{THE STORY OF AN ENTOMOLOGIST}

in the case of the forest entomologists), for we were always close to some kind of agriculture; but everyone who has ever travelled extensively among farming communities will appreciate the wealth of humorous incidents, the great number of unusual people, and, in a small way, the inconveniences and hardships. I have just spoken of the forest entomologists. Once when I was starting out from Washington I told my wife that incidentally I intended to visit a logging camp in northern California. She begged me not to do it. She said that it would be dangerous and that I ought not to take any risks. I didn't know the country, but I reassured her and started out. Eventually, after a long journey with many stops, I reached Klamath Falls in the heart of the great forests. I had expected rough quarters and a roughish life, but there were several omnibuses at the station. I asked one bus driver which was the best hotel. "Oh," he said, in his frank, honest, Western way, "that isn't my hotel. You'd better go to the White Pelican." Which I did. And the White Pelican proved to be the best and most up-to-date hotel that I had seen since I left the east. The pages were in uniform; there was an electric grill; many rooms had baths; and there was an elevator service that could hardly be surpassed. I thought of my wife's fears and went to sleep, probably, with a broad grin on my face. The next morning a trained assistant called with an automobile and took me to the camps and the surrounding forest. I encountered no dangers whatsoever.

These trips were nearly always taken in the summer months. By the first of September or a little later the chiefs of bureaus had to be back in Washington to prepare their annual reports which went to the Secretary of Agriculture on the first of October. The Secretary then wrote his own annual report, based largely on the information handed in by the chiefs, and this report he submitted to the President on the first of November. 


\section{FIGHTING THE INSECTS}

The President, having in hand the annual reports of all of his Cabinet officers, then proceeded during the month of November to write his own annual message to Congress, which of course was read on the convening of Congress on the first Monday in December.

Although when we think of the great growth of the Service in little more than thirty years, brought about by public necessity, by increased financial means, and above all by good things accomplished, this growth seems very rapid, still at the same time it did not seem so rapid to us who were in the middle of things. I, for example, did not fully appreciate it. It was really a busy and exciting life, and it was thoroughly congenial. I did not have time to stop and attempt to think broadly over the whole field. Important things were pressing all the time. But there was growing constantly an added respect for the potentialities of insect life, and an appreciation of the fact not only that we were doing necessary work but that it was pioneer work and that we needed more help. We needed more entomologists, trained in the latest methods, and also we needed the appreciative assistance of workers trained in many other lines. We began to see that the plant physiologists, the farm planners (agronomists), the agricultural engineers, the men trained in chemistry and in physics, could be of the greatest assistance, if they could be brought to see it. And so we began eventually and at first very guardedly a campaign of public instruction.

We wished above all things to avoid the accusation that we were trying to scare people unnecessarily. Unfortunately, however, we did not entirely escape this accusation. The ideas that we put forth proved to be popular with certain newspaper men and certain space writers. Some of these people, although trained writers, did not appreciate the importance of exact scientific 


\section{THE STORY OF AN ENTOMOLOGIST}

truthfulness, and many of my friends, especially those whose sense of humor was somewhat distorted, were inclined to chaff us. Professor Frank Wigglesworth Clarke, a famous chemist and an equally famous joker, once said to me, "I never see you without thinking, 'Let us spray." " 1

We have been joked about our extraordinary but well-founded estimates of money loss, and since we began to talk and to write seriously about the matter a facetious friend said to me one day at the Club, "You are as bad as the roadside advertisements. You make me tired." But I was used to him. He would have made me tired if he had not said it with a twinkle in his eye which showed that he really agreed with me.

Thus as time went on in the earlier part of the present century more and more men came into the work, more new ideas came to light, and new fields opened up. We gradually came to appreciate tha: we must know absolutely everything about insects from the first segmentation of the egg down to the last detail in the behavior of the adult. Not only must all insects be classified and named, but we must understand their intimate physiology and all of the things for which we have no better term than psychological. So as the workers increased in number and new minds became attracted to our problems, we became encouraged and more hopeful. I used to go to my desk of a morning in an expectant frame of mind. The feeling in the United States among the entomologists had spread all over the world. The entomologists of all nations had come to appreciate the fact that national boundaries did not exist, that we were working for all

${ }^{1}$ Here is an example of Clarke's readiness in witty response: $\mathrm{He}$ was at the time the President of the American Chemical Society and had not as yet been elected to the National Academy of Science. He was sitting at the Cosmos Club when Dr. Ira Remsen, the President of Johns Hopkins University and President of the National Academy, also a great joker, entered the room and seeing Clarke, said, "How are you, Professor Clarke? How goes it with the Comical Society?" "First rate," said Clarke. "How goes it with the Notional Academy?" 


\section{FIGHTING THE INSECTS}

humanity. Until the very end of my official career, I never opened my morning mail without the joyful feeling that perhaps among the letters I would find the announcement of some important discovery, and frequently that happened. There was thus the sense of adventure in the work and of adventure of far import.

I believe that it was not until 1920 that I first began to formulate in my mind the enormity of the problem. I had just translated Bouvier's book, "La Psychologie des Insects," 1 and through it had become acquainted with the more or less imaginative early writings of Maeterlinck. I think very likely that these had a strong effect on me, because during that same summer I wrote an address to be read as the retiring address of the President of the American Association for the Advancement of Science, and that address concerned itself principally with the subject, "War against the Insects." I was greatly encouraged by the reception of this address. Newspaper men and magazine writers took up the topic, and I suddenly found myself considered as a propagandist, which, for a modest scientific worker supposed to deal only with facts and not with theories, was at first rather disconcerting.

This suggests a rather serious thought. The average scientific man absorbed in his work does not welcome newspaper publicity. But I have always had a kindly feeling for newspaper people. And then, too, there have always been in Washington some of the cleverest men in the newspaper profession. The great journals have always had representatives there who were very able men, and I have known many of them. To the best of them, almost everybody in Washington, from the President down, would talk freely, confident that the information would not be

1 The Century Co., New York, 1920.

$$
\text { [ I64] }
$$




\section{THE STORY OF AN ENTOMOLOGIST}

misused. By talking freely to such men at just the right times, by not forcing oneself upon them, and by treating their juniors with courtesy, a scientific man, especially if he be engaged in applied science, soon finds himself known to the public. That happened in a minor degree to me. I did not realize its dangers for a long time; and I am not at all sure now that it is not far more desirable than undesirable. At any event, newspaper people have always been good to me, and I am very sure that their help to the Service has been great.

The first time that I realized that newspaper notoriety might be a disservice was many years ago. I had been lecturing before the National Geographic Society in Washington on the subject of Medical Entomology. When I came out of the building to the street I found a tall, fine-looking man, apparently in his fifties, awaiting me. He introduced himself as Major Louis Livingston Seaman, and I at once recognized him as a medical man who had written much, who had been a great traveller and who was greatly interested in army medicine and hygiene. He had stirred up the "canned beef" scandal in the Spanish War, and had recently published a book entitled "The True Triumph of Japan," which pointed out the great advance that Japan had made in the Russo-Japanese War in army sanitation. Major Seaman at once confessed to me that he had had the opinion that I was a publicity seeker, and that, being in Washington, he had come to the lecture to convince himself. He was good enough to say that the lecture was strong and sound, and that he had entirely changed his opinion of me. Naturally, we later became very warm friends. But it was a great shock to find out that so big a man should have formed so unfavorable an impression from the fact that the newspaper men had frequently quoted me.

Intelligent people who are getting along in years have noticed $[165]$ 


\section{FIGHTING THE INSECTS}

great changes in the way scientific measures have been handled by the press in the United States. Back in the 1870's the great metropolitan dailies devoted much space to the accounts of the meetings of the American Association for the Advancement of Science, and many will remember that when Thomas Huxley came to the States in 1876 the big New York dailies published his lectures in full. I well remember, in fact, that when I was a junior in college we had to digest these lectures as they were printed in the New York Tribune.

But there came a great change and it was a degenerative change. Reports of scientific affairs became greatly shortened. The flippant reporter developed until there came a time when almost no scientific functions or other matters were treated seriously. Intelligent and serious-minded reporters were not assigned to scientific functions. I remember, for example, a meeting of the American Society of Naturalists held in Chicago about the end of the last century. The American Society of Bacteriologists was one of the societies that met with the naturalists. Professor F. G. Novy of Ann Arbor was down for a paper on a new bactericide, and I went to hear him. His talk seemed to me to be very important. He had discovered a new compound (I think it was a peroxide of one of the benzols) which was instantly fatal to all forms of bacterial life-as fatal as direct sunlight. And what a field this discovery seemed to open up! But the compound was extremely expensive. As I sat there, listening absorbedly and my mind filled with the great possibilities suggested, a young chap, apparently not more than twenty, who was sitting next to me, whispered to me that he was a cub reporter sent there by one of the great Chicago dailies to report the meeting and that he could not understand the import of Dr. Novy's paper. This incident illustrates very well the news value of scientific stuff to city editors at that time. 


\section{THE STORY OF AN ENTOMOLOGIST}

The situation grew to be so bad that the American Association for the Advancement of Science decided to employ a press editor. The late Theodore Waters, a very clever and intelligent reporter and magazine writer, was chosen. He was an acknowledged member of the newspaper fraternity and knew newspaper men and how they thought. He was employed to see not only that the best things were properly reported, but that flippant and derisive articles were not written. I shall mention in another chapter an amusing story of how he did this. ${ }^{1}$ With Waters' efforts the situation began to improve, and this improvement has gone on rapidly ever since.

A clever scientific man, a chemist, named E. E. Slosson, wrote a book entitled "Creative Chemistry" and showed to a marked degree that science may be made vitally interesting by the right kind of a writer. The eyes of newspaper editors were opened to the fact that they had been neglecting an enormously interesting field. Mr. Scripps, of one of the great press associations, got this idea at an early date, and talked much about the subject with his friend Professor W. E. Ritter of the University of California. From these conferences came the founding of Science Service, which has on its board of control representatives from the National Academy of Sciences and the American Association for the Advancement of Science to insure the scientific accuracy of everything put out. Its director was Dr. Slosson, who was

${ }^{1}$ Waters, dear fellow, died rather recently. When he left the American Association he became connected with the Christian Herald and late in the World War was sent on a relief supply expedition to the Orient. He had become a great friend of my youngest daughter, who, he knew, intended to become a newspaper woman, and he wrote her a letter on the steamer somewhere off the east coast of Africa in which the following paragraph occurred: "And if, Janet, you wish ever to express the idea of sheer and utter ineffectiveness" (he had told her in the preceding sentence that some hens had broken from their coops on board) "think of a flock of hens scratching for worms on the iron deck of a tramp steamer in the Indian Ocean." 


\section{FIGHTING THE INSECTS}

succeeded by his chief assistant, Dr. Watson E. Davis, another scientific man who can write.

Even before the founding of Science Service, however, the space devoted to scientific news in many journals increased greatly and manuscripts were accepted from certain scientific men who found that they could write. Many magazines followed suit. And at the present time I think that science is receiving nearly adequate attention at the hands of the press. Some of us old timers, however, have a feeling that in certain cases scientific workers of great promise, having found that they can write acceptably and that they are well paid for doing so, are in a way abandoning fields of research in which they could do more permanent good.

Not only with the Science Service but also in other ways is this press reporting of scientific matters becoming systematized. For example, Mr. Austin H. Clark of the National Museum, a man broadly trained, especially in biological science, has taken on the duties of press secretary of the great old association. He tells me that the newspapers are avid for good sound stuff. Surely the average reader of newspapers has had no difficulty in getting adequate ideas of the important features of all the recent meetings. Even over here in Europe, where I am writing this in the early spring of 1932, I have had no difficulty in following the course of events at the January meeting of the Association at New Orleans. 


\section{Chapter IX}

$\mathrm{B}_{\mathrm{r}}$

THE time I assumed the office of Chief of the Service in June, 1894 , it had become apparent to me that there had been going on for a long time an interchange of injurious insects between countries. Of course this was a perfectly unwitting exchange and came about ignorantly in the course of international commerce. It was obvious to us that the United States was one of the greatest sufferers in this way, although there had been striking instances in European countries as well, at least for a hundred years. As we have already shown, the Woolly Root Louse of the apple, for example, appeared in England in the seventeen hundreds, and became known as the American Blight; and many years later, the Grapevine Phylloxera was found to have been carried from North America to many different parts of the world, and, in fact, brought about a strict quarantine in many countries against American vines.

But the United States had done nothing, and in the meantime rapidity in steamship transportation was increasing. As a result, more and more insects were being brought in, and many of them had become established.

It is worthy of note that the State of California passed a [ I69] 


\section{FIGHTING THE INSECTS}

quarantine law as early as I88I, but the other States did nothing, and the Federal Government took no action.

In I895 I took as the subject of my address as retiring chairman of the Section of Zoölogy of the American Association for the Advancement of Science "The Spread of Land Species by the Agency of Man, with Especial Reference to Insects." I brought together what seemed to me a rather impressive series of facts and arguments. I had intended to go into the matter more deeply than I did and to watch personally the arrival and unloading of transatlantic steamers in order to investigate the possibilities of the introduction of what might be termed "chance passengers" in the way of insects other than those attached to, or contained in, plants or plant products. I was unable to do this, but I think the argument, as it stood, was almost as strong as if I had done it.

About this time other State laws began to be passed, and these laws were collected and published in successive bulletins by the United States Department of Agriculture.

In 1895 , in an address entitled "Injurious Insects and Commerce," delivered before the Peninsular Horticultural Society at Dover, Delaware, I made a strong plea for the extension of such legislation, calling it "the crying need of the present time." And the following year I delivered a similar address before the Massachusetts Horticultural Society at Boston.

In the meantime, I had begun a study of those pests to agriculture in various foreign countries, especially those that had not yet made their appearance in the United States, but that were likely to be introduced in the course of commerce and were potentially extremely dangerous. In I897, I used much of the information thus gained in an article entitled "The Danger of Importing Insect Pests," published in the Yearbook of the United States Department of Agriculture. 


\section{THE STORY OF AN ENTOMOLOGIST}

At that time the orange-growers of California were much exercised over the possibility of the importation from Mexico of a maggot that damaged oranges in the state of Morelos, the exact Mexican distribution of which was not known. California, in fact, quarantined against all Mexican oranges. It was suspected in some quarters that this quarantine was rather unjust, and that it was passed very largely to avoid competition between Mexican and Californian oranges, more especially since the Mexican oranges came on the market earlier in the season than the Californian ones. Since most Mexican oranges that had hitherto entered California came from the adjacent state of Sonora in Mexico, I took my first Mexican trip in the autumn of 1898 , to find whether this particular insect really existed in that state.

It was a wonderful trip, and many funny things happened. I had never been in Mexico before, and did not realize how very peaceable it was under the somewhat autocratic administration of President Diaz. So I took among my collecting supplies a very serviceable revolver. I went down from Nogales to Hermosillo, investigated the large citrus plantations there, and then went on to Guaymas, on the shore of the Gulf of California. As I wished to go into the interior and to investigate both citrus and cotton, the Swiss proprietor of my hotel engaged a man with an open carriage to take me out to San José de Guaymas. The driver was a villainous-looking chap, pockmarked and with slightly crossed eyes, and as I sat on the seat behind him I furtively reached into my toilet bag, took out the revolver, and put it into the side-pocket of my coat. At that time I knew only a word or two of Spanish. After a bit I noticed some little donkeys by the roadside, and said interrogatively to the driver, "Burros?" To which he replied amiably, "Sí, sí." And then there was a silence for a few moments. Then he turned his head and said "Burros Americanos muy grande?" To which I replied, "Sí, sí." 


\section{FIGHTING THE INSECTS}

Encouraged by my agreement, he said something else in Spanish which I could not in the least understand, but to which I replied wisely with, "Sí, sí." I was beginning to enjoy the conversation and so I quoted to him the opening paragraphs of the Declaration of Independence. He quite agreed, and was evidently in a conversational mood, since he assented with a smile, "Sí, sí," and began a long monologue which, for all I knew, might have been a chapter from "Don Quixote." By that time I was ashamed of my revolver, so I took it out of my pocket and put it back in my bag. It was a delightful conversation, but neither of us understood a word the other one said, except the extremely useful "Sí, sí."

Eventually we arrived at San José, and I was deposited with a letter of introduction at the rancho of a man named Parodi. Parodi was an Italian who had come out from Italy to British Columbia, where he was engaged in mining until the climate and the hardships drove him south, when he went to Mexico, the land of the sun. He had picked up some French somewhere, he knew Italian, of course, and had learned a little English in British Columbia. That was the reason I had been sent to him. He was a successful ranchero, had accumulated quite a large property, and had gained the dictatorial, masterful way of addressing people common to men who associate with peons. I remember that two or three times a day he would come out into the field where I was watching insects and remark in a loud voice, "Well, what you say?" And I would reply with an ingratiating smile, "Anything you like." He always said then, "Let's have a drink." If I agreed, as I generally did, he would march majestically back to the rancho, with me following meekly behind. When he reached the porch he would say, "Take a seat," and then would enter the house and come back with a big bottle and glasses and would say as solemnly as though it 


\section{THE STORY OF AN ENTOMOLOGIST}

were a religious rite, "All strong drinks is bad! But ze best of zose strong drinks is mescal! Help yourself."

Parodi's versatility as a linguist was notably shown one night at dinner when an interesting insect buzzed in and alighted on the table. I reached for it, and Parodi warned me in three languages spoken at once: "Gardez! gardez! zat animalito sting like ze dev." But it was too late. The insect was Rasahus biguttatus (Comstock calls it the two-spotted Corsair) and my forefinger was badly punctured.

I found no Morelos orange worms in Sonora, and so notified the California State government, but it had no effect on the quarantine, although it did furnish an excuse for a trip to Mexico by some of the State officials.

This was the first of a number of trips to Mexico, during which I made the acquaintance of the late Alfredo Dugés of Guanajuato, and of my warm friend, Professor Alfonso Herrera.

May I tell a little yarn connected with one of these later journeys? We were going south on the Mexican national line from Juarez. In the carriage with me were Joseph Greusel, an old newspaper man of Cleveland, Ohio (now dead), and a younger Cleveland lawyer. They were going down to Oaxaca to look after some mining interests. At a certain point the train stopped for a little time, and there was some sort of a commotion outside. Greusel put his head out of the window and said, "Hello, what's all this?" There was a fourth man in the compartment, a young Mexican mining engineer who had studied at Stanford University, and who therefore spoke rather fair English. The Spaniard said, "Zis place is Hildalgo, where Hildalgo, ze priest, sound ze tocsin of Mehican liberty in I8I4, and today is the Mehican Fourth of July. Ze young man at ze head of ze procession is ze gran'son of Hildalgo." Greusel was 


\section{FIGHTING THE INSECTS}

very much impressed, and said, "By George, how interesting this is!" In the meantime the young Mexican engineer stepped out on the back platform and said to the crowd in Spanish that the man with his head out of the window was the grandson of George Washington. Whereupon the crowd broke out with lusty Vivas, all directed at Greusel, who withdrew his head and said to us, "This is one of the most interesting international incidents I ever encountered. I must write it up for my home paper." The Cleveland lawyer then remarked, "But, Joe, we didn't see the whole show. We didn't see the grandmother of Hildalgo." Joe said indignantly, "Are you pulling my leg? Are you kidding me?" And the young Mexican engineer said joyously, "Certainlee, Hildalgo, he was a priest, he was a celibate, he could have no descendants." During the next few weeks we met a number of English-speaking people who were mainly American and English mining men, and I told this story several times in Greusel's presence. Finally he said to me, "Doctor, that's a darned good story, and you tell it well. But if you do it again, I'll write it up for my paper and make you the butt of the joke." Newspaper men can do pretty well as they please with us, after all. They can, to a certain extent, make reputations and unmake them.

Conditions in Mexico prior to 1904, under the régime of Porfirio Diaz, were very stable, and it was a great pleasure to travel in that beautiful country. I remember that once I called on the governor of the state of Oaxaca and asked for information about the cotton-growing regions in his state. He told me that he would get the information for me in two or three days, and that he advised me meantime to visit the ruins of Mitla, some thirty miles from Oaxaca. He said that he would give me a detachment of Rurales as an escort. I expostulated and told him that conditions were so very peaceful that I would not need 


\section{THE STORY OF AN ENTOMOLOGIST}

a military guard. He replied that although that was perfectly true, I could use the soldiers to collect insects for me!

On another occasion I called on Dr. Eduardo Liceaga, the president of the Superior Board of Health in the City of Mexico, at a time when I wished to study the geographical distribution of the Yellow Fever mosquito in Mexico. Dr. Liceaga had been one of the first Mexicans to accept enthusiastically the findings of the Walter Reed Commission concerning the transfer of Yellow Fever by a certain species of mosquito. He told me with much pride (this was in 1904) that he had organized the whole republic in such a way that there was perfectly satisfactory mosquito inspection going on at all the principal points, and he showed me a detailed list of inspectors on his pay-roll at each place. I went gradually from the City of Mexico (eight thousand feet elevation) down to the seaboard at Vera Cruz, stopping at several points on the way, including Orizaba and Córdoba. At each point I searched for Liceaga's inspectors, and at last in Córdoba I found a lady who told me that she had seen a solitary lazy Indian with a sign on his cap and a quart can of kerosene. Evidently Liceaga's inspectors were drawing their pay from the government, but it is doubtful if they did much work.

While at Córdoba, by the way, an American lady, Mrs. Mary Knight Wood, a composer of charming songs, gave a little tea party and invited a number of people who understood English. Among them was a young girl of seventeen, a Mexican, who in rather efficient but halting English said to me, "It must be very embarrassing for you to see the monument in our principal plaza." It was a monument erected to heroes who died in the war of 1847 against the United States. I replied that it was a beautiful monument, and that the sentiment was also beautiful, but I asked why I should feel embarrassed. She replied that it was because the Mexicans had won the war. 


\section{FIGHTING THE INSECTS}

"Why," I replied, "I thought that the United States won that war."

"Oh, no," she said. "Our school histories all say that Mexico won it."

This reminded me strongly of the collection of school books published in the Southern States during our Civil War. I remember an arithmetic, for example, in which one of the problems was: "If one Southerner can whip seven Yankees, how many Yankees can eleven Southerners whip?" And this, of course, reminds me of the books on American history that were published during my schoolboy days and the prejudices against England that were built up in the minds of all the children in the States by the lengthy accounts of the Revolutionary War.

My last trip to Mexico was in 1904. This was the journey on which I was studying especially, perhaps, the geographical distribution of the Yellow Fever mosquito, and at the end of the investigation I learned that the dread disease had just broken out at Laredo on the Rio Grande. I knew that the State of Texas would be up in arms with a rigorous quarantine, including a shotgun barrier along the river, and I had no wish to be held in a detention camp. So I went to the office of the Morgan Line Steamers in the City of Mexico to look for passage by steamer from Vera Cruz to New York. I bought my ticket, and in paying for it brought out a United States government transportation request.

"Oh," said the clerk, "you are one of those government fellows. One of them was in here a few weeks ago, bought a ticket on one of those requests, and borrowed fifty dollars from me, which he has never returned."

I overcame his scruples and got my ticket, and afterwards discovered that the man who negotiated the loan was a member of [ $\mathrm{x} 76]$ 


\section{THE STORY OF AN ENTOMOLOGIST}

the party that included Pothier and Beyer of New Orleans, and that had been sent out to investigate the cause of Yellow Fever. They were sent by the United States Public Health Service, and it may be remembered that they reported that they had discovered the causative organism. It may also be remembered that a later party, headed by Rosenau, sent out by the same service, decided that this organism was nothing but a yeast cell.

On the journey home our steamer towed a great barge from Vera Cruz to Progresso, Yucatan, carrying some hundreds of Yaqui Indian prisoners and their families, who had been concerned in a rebellious uprising in Sonora and who had been condemned to labor in the hennequin plantations.

We also stopped in Havana Harbor. As I have said previously, I was the only person allowed to go ashore, on account of the Yellow Fever scare.

Since those days Mexico has had no end of trouble, and the old peaceful times have often seemed far away. My friend, Herrera, for example, has had tremendous ups and downs. Under the Huerta régime he lost his post and much of his private property and with his family started to flee for the coast. But his train was attacked by revolutionaries, and, escaping with difficulty, he reached Córdoba, to be attacked by brainfever. He remained for weeks in a hospital, but finally, with his family, reached Vera Cruz, in a deplorable state of health and in financial distress. This happened to be just at the time of the American occupation of Vera Cruz during President Wilson's early administration, and Herrera managed to get a cable through to me, telling me of his location and condition. General Funston was in command of the American Expeditionary Forces then in occupation at Vera Cruz, and I cabled him, telling him of Herrera and of the help he had been to the United States government by his kindness to our experts. Gen- 


\section{FIGHTING THE INSECTS}

eral Funston at once sent aid from his Quartermaster's Department. Eventually Herrera returned to Mexico City, and under the following administration resumed his work and finally organized a Department of Biological Studies.

Years later destructive locusts invaded some of the southeastern states of Mexico and played havoc with the crops. A competent German, Dr. Alfonso Dampf, who had done work in the tropics, was engaged to investigate this matter, and eventually was made Chief of the Department of Research and Pest Control in the Federal Office of Agricultural Defense.

In spite of Mexican internal troubles, experts from the United States have been sent down there on entomological problems, and some have been stationed there for a long time. I remember that at one time we had a laboratory in the so-called Lagunas district, and a cheerful photograph that one of the men sent me showed the body of a revolutionista hanging from a tree immediately in front of the laboratory entrance. Under the present government (this is written in 1931) coöperative work is being carried on in a mutually helpful and very cordial way between Mexico and the United States. A competent laboratory has been furnished by the Mexican government in the federal district and it is manned by American experts. Its purpose is largely to study the so-called "fruit flies," and its necessity is emphasized by a serious outbreak of one of these flies in the new citrus orchards on the Texas side of the Rio Grande, and by the remarkable outbreak of the Mediterranean Fruit Fly in Florida in the late winter and spring of 1929.

Mexico is a wonderful country, and she has had some wonderful men. I remember Señor Limantour when he was Secretario de Fomento, a cultivated, broad-minded statesman of whom any country might be proud. And I remember my friends among $[178]$ 


\section{THE STORY OF AN ENTOMOLOGIST}

the scientific men. Undoubtedly Mexico has a great future; but when?

In those days the United States was fairly well protected against injurious insects from the Orient by the State inspection services on the Pacific coast. But the Atlantic coast was more dangerous on account of the greater rapidity of steamship service from Europe. For many years-in fact, from i 898 to 1912-concerted efforts were being made to pass a satisfactory plant quarantine act by the federal government that should measurably protect the whole country. Many hearings were held before congressional committees and several bills were prepared. All of them met the strenuous opposition of the National Nurserymen's Association through its committee on legislation. Finally, in early 1912, despairing of success in our own country, I went to Europe to try to get certain European governments to strengthen their own plant inspection laws, and to secure in this way a competent system of inspection of and certification of plants and plant products going to America. I interviewed high officials in England, France, Belgium, Holland and Germany with a fair degree of success. I met with fair promises and great courtesy everywhere, and in some cases the inspection services were strengthened. I remember suggesting to $\mathrm{M}$. Vassilière that it might be a good plan to station American inspectors at some important points, like Angers, for example, and he replied that that was entirely out of the question, since it would create a bad diplomatic precedent. Later I remember that at a hearing before the United States House Committee of Agriculture the same suggestion was made by Mr. Lever of South Carolina, at that time Chairman of the committee. I told him M. Vassilière's comment, and he at once acknowledged its force. 


\section{FIGHTING THE INSECTS}

After all my hard work with these officials in Europe during June and July of 1912, I received, early in August, in London, a cablegram from the Hon. James Wilson, then United States Secretary of Agriculture, stating that a competent quarantine bill had just passed Congress and had been signed by the President. Thus my summer's work had been entirely unnecessary, although my interviews with different people had been extremely interesting, and of much educational value.

The individual credit for this legislation on the part of the United States is due almost wholly to my then first-assistant and ultimate successor in office, Dr. C. L. Marlatt, who was promptly made the chairman of the Federal Horticultural Board, and who administered its affairs with great tact and firmness.

All this is a legitimate part of the story of an entomologist, although, as a matter of fact, all of these quarantine efforts were directed not only against injurious insects but against plant diseases. Before leaving this subject, it may be well to mention briefly the International Conference of Economic Entomologists and Phytopathologists, held in Wageningen in Holland in 1923. I strongly suspect that this conference was called by the Dutch people for the purpose of strengthening the international feeling on the subject of the so-called Quarantine No. 37, then recently promulgated by the United States government. This restricted the importation into the United States of all bulbs, except under certain conditions, and I am inclined to think that I was selected as Honorary Chairman of the Conference with the idea that I might be brought to favor its aim. But this of course may not have been the case. The conference was largely attended by men from different countries, and there was a strong delegation of Americans, none of them, however, connected in any way with the Federal Horticultural Board. There were visits to large bulb-growing districts, and luncheons [180] 


\section{THE STORY OF AN ENTOMOLOGIST}

and dinners presided over by the Burgomasters of different towns, and everywhere the injustice of the American ruling was pointed out and insisted upon. Any danger from the importation of Holland products was declared to be absolutely non-existent. It was a very interesting situation for the American delegates. We could sympathize with the Hollanders and declare regretfully that we had nothing to do with the ruling and could not influence the Board. But I shall tell all about this conference in the next chapter.

The Wageningen conference did much good, even though it had no effect upon the United States Quarantine No. 37. It brought the scientific men of the different countries together, made new and lasting friendships, and started, internationally, a coöperation between the plant disease men and the agricultural entomologists that is bound to become closer and closer.

Ever since 1912 the Plant Quarantine Service has operated very successfully in the United States and has received increasing Federal appropriations for its support. I think we may all be thankful that it was started. At one time it was thought that appropriate inspection work for dangerous insects could be performed under the Bureau of Entomology, and for plant diseases under the Bureau of Plant Industry. But such an arrangement would have complicated greatly the work of those two organizations. I mentioned increasing appropriations just now. It should not be forgotten that a few years ago Congress with the acquiescence, but rather against the advice, of the experts, appropriated the huge sum of ten millions of dollars, to be expended in an effort to check the spread of the European Corn Borer. And none of us will forget the speedy appropriation of over four millions of dollars in the spring of 1930, for the purpose of wiping out the Mediterranean Fruit [181] 


\section{FIGHTING THE INSECTS}

Fly in Florida. Both of these appropriations were expended largely by the Plant Quarantine Service.

Of course the Bureau of Entomology and the Bureau of Plant Industry coöperate loyally and cheerfully with the Plant Quarantine Service, many of the experts in these bureaus constantly being called upon for advice. Naturally, moreover, a few experts in entomology and plant disease are officially connected with the Quarantine Service. Dr. Marlatt, the first Chief of the Service held, at the same time, the post of associate chief of the Bureau of Entomology. When I retired, in 1927, he became Chief of the Bureau. The problem of choosing a new chief for the Quarantine Service was a serious one and took many months of careful consideration. Finally Mr. Lee Strong, who for a number of years had been connected with the California Quarantine Service, was given the post, and he has directed the work admirably.

The comparatively new plant quarantine has created many disturbances and has caused much opposition in some quarters. I wonder if its principal officials have not passed many sleepless nights. Some of its important and quite necessary decisions have almost disturbed diplomatic relations. Surely they have caused changes in commerce and in industry! Experienced bulb-growers from the old countries, for example, have come to America and have started enterprises of their own in the United States. And our country is growing an infinitely greater number of plants than heretofore in her commercial nurseries. There are many annoying problems that come up all the while. I ran into one of them accidentally after I had retired from office. I happened to be in Seattle, Washington, at the time, and the inspectors at that port were so worried about a question that had arisen that they consulted me. I am telling this story simply to indicate the worries that these people have 


\section{THE STORY OF AN ENTOMOLOGIST}

all the time. A serious enemy to growing rice in the Orient is the Rice Stem Borer (Chilo oryzceellus). These Seattle inspectors showed me a lot of cheap toys that were coming in from Japan and that were intended for the Woolworth Ten Cent Stores. They were addressed to many parts of the United States and were all packed in rice straw. On opening some of these straws they found the larvr of this destructive pest alive and healthy. What was to be done? Rice straw was probably the only cheap packing that the Japanese had. The articles in which it was packed were so cheap that the expense of fumigation or other treatment was not to be considered. And yet they were to go almost everywhere in our country. Rice culture has extended enormously in the United States, possibly principally upland rice in east Texas and in the Sacramento Valley in California. The demand for rice has increased, and the sea islands on the coast of South Carolina and Georgia can no longer supply it. Moreover, the Rice Borer will probably attack other large-stemmed graminaceous plants. What a problem! I don't know how the Plant Quarantine Service has solved it. Possibly this new pest has already got a foothold in the States, but if so, I have not heard that it has been discovered.

Great credit not only for the operations of the Board for many years, but for the passage of the law, belongs to Dr. Marlatt; but I like to think of what I did in the early days to help bring about a popular sentiment. The whole history, I think, comes quite properly into the story of an entomologist. 


\section{Chapter X}

\section{$\mathrm{N}$}

EARLY everybody believes theoretically in Internationalism, and there is no movement that leads toward international understanding more than the tendency to hold international meetings and conventions on all sorts of topics. I once wrote an address on the evolution of Internationalism, but I shall tell about that later.

It is true that the big international gatherings of representatives of different nations brought together for political purposes are likely to break up in an indecisive way. But the smaller gatherings of people interested in some special line of endeavor bring about personal friendships among people of different countries, expose a community of ideas that are extremely enlightening, and promote an international understanding the extent of which can hardly be realized.

I have been lucky enough to attend a number of these gatherings, and I am sure that the work of the Federal Bureau with which I have been officially connected has been greatly helped by the contacts made. I am sure also that the same thing holds for organizations from other nations whose representatives have come together in this way.

The first international gathering of the kind that I ever [184] 


\section{THE STORY OF AN ENTOMOLOGIST}

attended was in St. Louis in 19c4. The managers of the World Exposition held that year in that city had arranged for an international congress of arts and sciences, and had not only sent certain distinguished men to Europe to carry personal invitations to well-known men over there to come to the congress and read papers, but reinforced the invitation by the information that all their travelling expenses would be paid. It was a big gathering. Many of the world leaders in things intellectual were there, and there was a notable series of addresses. There were also many important receptions, dinners, and affairs of that kind.

The organization of the congress into sections had already been arranged, and the programs had been practically made out, when some one suggested that it might be desirable to have an executive secretary to attend to such matters as the arrangement and assignment of meeting halls, registration and all other deails. I was appointed to this post only thirty days before the opening of the congress, and reached St. Louis ten days before the meeting began. I had great difficulty in finding the requisite number of meeting halls, and many other details were very puzzling; but as I had for some years been permanent secretary of the American Association for the Advancement of Science, the experience was there, and things probably went better than they would have if a person unaccustomed to such affairs had had charge.

Professor Simon Newcomb was the president, and, naturally, the majority of the speakers were drawn from the faculties of the leading American universities.

There was a bit of quiet rivalry among some of these institutions, notably between Columbia and Harvard, concerning the number of men selected from each institution. St. Louis was crowded at that time, the Exposition was in full swing, and 


\section{FIGHTING THE INSECTS}

the details of travelling in the United States were new to the European guests. Many difficult situations had to be straightened out. On the very valuable suggestion made, I think, by Hugo Münsterberg, six young American Doctors of Philosophy, familiar with certain European languages, were appointed to assist the executive secretary, especially by way of concerning themselves with the comfort of the European delegates. One of the difficulties that we encountered was a most unfortunate glut of luggage. Many of the Europeans, unfamiliar with our checking system, were greatly worried when they were not able instantly to reclaim their trunks, and so on. I remember one German professor who wailed in despair for two days because the box that contained the manuscript of his speech had not arrived.

An interesting incident was connected with the arrival of Henri Poincaré, the famous French mathematician. He made his first appearance at the registration office early one morning. I was not there, but an assistant was at the registration desk and he told me the story. Poincaré knew no English, and this particular assistant did not understand French, so they were apparently at a deadlock. But the Frenchman said in his own language that he had been invited by Professor Newcomb. The assistant caught the name, and by signs indicated that he would conduct the visitor to Professor Newcomb's room. They went to the dormitory where Newcomb was quartered and rapped on his door. A voice sang out, "Come in." The assistant opened the door and discovered the Washington astronomer in his bathrobe and wearing a most forbidding expression (with his leonine head and shaggy hair and beard he could seem most formidable). Poincaré advanced at once with hand extended and said, "Oh, Professeur Newcomb!" Then, seeing that he 


\section{THE STORY OF AN ENTOMOLOGIST}

was not immediately recognized, added, "Je suis Poincaré. Vous vous rappellez que vous m'avez invité personellement."

"Why," said Newcomb, somewhat staggered and for the moment forgetting himself, "you said you couldn't come." Then, recovering himself, he smiled broadly and went on, "Je suis enchanté-" etc., etc.

When Newcomb died some years later in Washington his friends held a memorial meeting, and I was one of the speakers. As was quite proper, the other speakers were solemn on the whole, but I permitted myself to tell the story I have just related. Mrs. Newcomb and her daughters were there, and I had some doubt as to how they would receive it. But they said that they were very pleased, and Mr. James Bryce, who was one of the other speakers, told me that he thought the incident was characteristic of Newcomb.

After Newcomb retired from the Naval Observatory, he took his luncheons regularly at the Cosmos Club, and he sat by preference, not with the scientific men, but with a group of architects. He told me that he thought architects were the most congenial people in the world. That to me was a new light on the great man's character.

The proceedings and transactions of this St. Louis Congress were published in a series of volumes that constitute a great record.

In 1907, the Seventh International Congress of Zoölogy was held at Boston, Massachusetts, under the presidency of Charles Sedgwick Minot, the distinguished comparative anatomist and embryologist of the Harvard Medical College. It is not my intention to write about the proceedings of this congress or of any of the other meetings of this kind that $I$ attended. At least, I shall not write about them in a serious way. But in some 


\section{FIGHTING THE INSECTS}

of the stories that I expect to tell, one may perhaps gain a slight idea of the effect of the coming-together of men of similar aims but of different home surroundings and methods of training. It is quite natural that the humorous incidents should stick more closely to my memory.

At Boston, the European countries were well represented. Many of the most prominent zoollogists in the world were there, and many matters of interest to the students of animal life were discussed. I went on from Washington and read the first paper in the section of Economic Zoölogy. I recall with especial pleasure that Vernon Kellogg, then of Stanford University, came to me after I had finished my discourse, his eyes shining with enthusiasm, and told me that my paper had made him regret extremely that he had not gone into the economic side of entomology, instead of interesting himself almost exclusively in the study and teaching of other aspects. I don't think that either of us at that time fully realized that the fundamental studies in which he had been engaged were basically of great importance from the point of view of applied science.

During the Boston meeting, the president, Dr. Minot, gave a dinner to twenty-five or thirty of us at the Saint Botolph Club on Newbury Street. It was a characteristically international dinner, and in welcoming us after the coffee Minot spoke in English, in German, in French, and finally, I think, in Italian. Admirable speeches were made by R. Blanchard of Paris and Professor Hubrecht of Holland. And then Minot called upon a well-known German professor. This was long before the days of Prohibition, and the wine had been circulating freely. When the German was called upon by name to say something, he did not rise, but said rather grumpily, "Wie kann man sprechen wenn es nichts zu trinken gibst?" Minot blushed, 


\section{THE STORY OF AN ENTOMOLOGIST}

touched the electric bell and ordered another case of champagne.

After the Boston meeting the congress visited New York and Washington. At the former city, there was a reception at the American Museum of Natural History. The director of the Museum stood at the beginning of the receiving line, with his charming wife next to him. As the visitors advanced in line one by one, he shook each cordially by the hand and presented him to his wife, and so they passed down the receiving party. This same German professor of whom we have spoken (and he knew no English) had noticed that the men ahead of him had announced their names, so when he reached the director, he said, "Heise Schmidt" (Schmidt wasn't his name, but it will answer for this yarn).

"Ah," said the director, "Professor Heise Schmidt, allow me to present you-"

Here the German interrupted him impatiently by saying, "Nur Schmidt."

"Oh," said the American. "I beg your pardon, Professor Nur Schmidt_- "

When the Congress visited Washington we gave them a number of interesting receptions, one at the Cosmos Club, one at the Zoölogical Park, one at the Smithsonian Institution, and a final one at the Congressional Library. As Chairman of the local committee, I presided at the meeting held at the Cosmos Club and introduced the Hon. H. L. West, then Commissioner of the District of Columbia, who made a capital welcoming speech on behalf of the District, and the Hon. James Wilson, the only member of the Cabinet at that time in Washington (it was then in late August) to welcome the Congress on the part of the Federal Government. Secretary Wilson made his usual good speech, and then Professor Blan- 


\section{FIGHTING THE INSECTS}

chard of Paris responded on behalf of the delegates. Blanchard was especially eloquent, but he used the French language (he knew a little English at that time but did not trust himself). In the course of this delightful talk he complimented Secretary Wilson highly and spoke especially of the very liberal policy of the United States Department of Agriculture in sending out its valuable scientific publications to all the countries of the world. These remarks were delivered so impressively and so beautifully that they were followed by vigorous applause, in which Secretary Wilson joined heartily.

A day or so afterwards I called at Secretary Wilson's office on a matter of business, and he said to me, "Doctor, that French professor was a real orator, wasn't he? I was greatly taken by his eloquence, although I couldn't understand a word he said. But I was carried away and applauded with the rest, and then it dawned upon me that he must have been saying very nice things about me, and that I had hardly done the right thing in applauding. It reminded me of Blind Tom, the wonderful negro pianist, who, at a concert, always applauded himself vigorously."

I think it was in that same year, 1907, that an International Congress of Agriculture was held in Vienna. I had been out in Russia and had come back from the Crimea by a Black Sea boat to Constantinople, and thence up to Budapest, where I left my courier and friend, Pichler, of the Hotel Hungaria, and then came on to Vienna and the Congress. I went to the Hotel Bristol and found my old guide, the then well-known courier, Carl Binder, who arranged matters for me with the local committee of the Congress. Of all the functions of the sort that I have ever attended, this one was possibly the most perfect. The local committee in charge of the arrangements 


\section{THE STORY OF AN ENTOMOLOGIST}

had done almost, if not quite, the best work of any organization of this kind I ever knew. There were all sorts of receptions, and many delightful mementoes of Vienna were given to delegates. The expense of the entertainment of the Congress must have been very great. The final dinner in the Burgomeister's Saale was incomparably admirable. To one from the United States, however, the most striking feature of the Congress was the evening reception at the Palace. Such an array of spectacular uniforms and decorations and women's costumes and jewels I had never imagined. But I was disappointed in Franz Josef. From his published photographs, I had pictured him as a man of heroic proportions and military bearing-an ideal emperor. When I saw the small, bent, senile person that he was at that time, I began to appreciate what has come to be known as the pathos of his reign.

I recall with especial interest one incident of this Congress. The Association of Bird Lovers of Austria had been allowed a special session of one of the sections of the Congress, for the discussion of the question of bird protection. Since it was an Agricultural Congress, it was obvious that the discussion would take the form of a strong advocacy of bird protection as an aid to agriculture. This happened to be a subject in which I had taken an especial interest. I had supported Antonio Berlese in his Italian work, and from my studies of the insect parasites of injurious species in the United States, I had come to the conclusion that by far the most important enemies of injurious insects are other insects. Considering the fact that birds feed rather indifferently upon various kinds of insects, I had even gone so far in my mind as to think that if the entire race of insectivorous birds were wiped out by some catastrophe, the balance of Nature would not be long upset. I have always

$$
\text { [I9I] }
$$




\section{FIGHTING THE INSECTS}

rather regretted this conclusion on account of what must, after all, be a sentimental interest in birds.

So I attended this particular séance. When I entered the room I found that my old friend, Professor J. Ritsema-Bos of Holland, was in the chair. The speakers in support of the birds were mostly pastors, I was told. The discussion was entirely in the German language. At the conclusion of a speech by one of these pastors, Ritsema-Bos said that in the United States much attention had been given to this question by a skilled scientific organization. Then he announced that I was present and invited me to say something on the subject. I protested that my faulty German would not allow me to express myself clearly and forcibly. Whereupon Dr. Max Hollrung of Halle, the well-known Nematologist, sprang to his feet and offered to interpret if I would speak in English. This I did. I argued that it was most unscientific and very unsatisfactory to speak of the food habits of birds in a general way simply from more or less casual observation, and that before any conclusions were reached it would be necessary to study the stomach contents of thousands of birds of different species. I said that such an investigation had been begun by the Bureau of Biological Survey of the United States Department of Agriculture, that already some thousands of these stomachs, collected at different seasons of the year, had been examined, and that already we had scientifically accurate information of the food habits of a number of our birds. These remarks were naturally received with silence, since very few who were there had understood what I said. But when my friend had put it into German there was strong applause, and the resolution under discussion was defeated or tabled or modified-I have forgotten which.

Although there were many fine men at this Congress, and there began for me there a number of friendships that became [ I92 ] 


\section{THE STORY OF AN ENTOMOLOGIST}

lasting, I was perhaps more particularly impressed by the personality of M. de Méline, former Minister of Agriculture of France. He was one of the most delightful men I have ever met, charmingly courteous, quick of wit, a wonderful speaker and apparently a thorough internationalist. He was at that time the president of the International Commission for Agriculture, and he held that position until the time of his death, many years later. The function of this commission was to arrange for the International Congresses of Agriculture held in different countries at intervals of three years, to prepare the programs, and in occasional intervening meetings at Paris to look over agricultural conditions for the whole world and thus to decide upon the questions to be discussed seriously at the congresses. Many of the functions of this commission, especially its broader ones, were afterwards assumed by the International Institute of Agriculture, which was founded with headquarters at Rome. The commission really acted as a permanent executive committee of the International Congresses.

This commission had apparently held a meeting before the final dinner of the Congress, and in the enthusiastic good fellowship coming with the breaking-up of the dinner, M. de Méline shook me warmly by the hand and told me that I had been elected the American member of the Commission. I have held this mernbership ever since, and have occasionally attended the meetings of the commission in Paris, which have always been held impressively in the great hall of the Académie d'Agriculture in the Rue de Belle Chasse. Incidentally, it may be stated that after the death of $\mathrm{M}$. de Méline he was succeeded by the Marquis de Voguë, who still presides. One of the most charming and remarkable personalities I used to meet at these meetings, a man of whom I was particularly fond, was M. Tisserand, 


\section{FIGHTING THE INSECTS}

another former Minister of Agriculture, and one of the grand old leaders of French farming interests.

In 1908 the English men of science arranged a great celebration of the hundredth anniversary of the birth of Charles Darwin. In the spring of that year I was appointed a delegate to this celebration from the Washington Academy of Sciences and soon afterwards left for an official journey that took me into Eastern Europe. In Budapest I was asked by my old friend, Geza Horvath, whether I expected to attend the Fête Lamarck in Paris in June. I had not heard of the fête, but was told that the French, on learning of the English plan to celebrate the Centenary of the birth of Darwin, had decided to anticipate it by a great Lamarck celebration. Lamarckian views of evolution were then being actively discussed, following the publication of August Weissman's work, denying the possibility of the inheritance of acquired characteristics.

This was an opportunity not to be lost, and I immediately wrote to Paris, proposing myself as a delegate of Washington organizations, and at the same time wrote to Washington for confirmation. So that summer I attended both of the big international scientific meetings.

The Paris celebration was impressive as well as charming. At the great opening meeting held in the Jardin des Plantes, in a large temporary structure facing the beautiful Lamarck statue, the President of the Republic, M. Faillières, was present, with that impressive personality, M. Leon Bourgeois, who at that time, I think, was Minister of Foreign Affairs, also in attendance. The principal address was effectively delivered by Edmond Perrier, at that time Director of the Museum of Natural History and a leader of the French Lamarckian School.

A number of distinguished Frenchmen received the foreign [ 194$]$ 


\section{THE STORY OF AN ENTOMOLOGIST}

delegates and showed them to their reserved seats at this function, and I recall that no less a person than Künckel d'Herculais did this for me. This leads me to a story. Many years earlier, this famous French scientist had charge of certain governmental investigations of locust outbreaks in Algeria. Suddenly one day the press dispatches in the newspapers fairly shrieked with a dramatic account of his death. It was stated that he had been overwhelmed by a cloud of locusts, and that the voracious creatures had completely devoured him, leaving only a part of a red necktie, by which his fate was realized. This announcement caused a great sensation, and scientific associations all over the world passed resolutions of regret. Biographical notices were printed in many languages. I recall that this was done at Washington, and that a speech commemorative of the supposed deceased was made by C. V. Riley, who had known him well.

It turned out, however, that the notices in the newspapers had been simply an instance of mendacious and sensational journalism. Many years later, at a dinner that the late Alfred Giard gave me, Künckel d'Herculais was present. After the coffee was served, Giard in his delightful way said, "Künckel, tell us about the time you were eaten up by locusts." The latter grinned and said, "While I am sorry on some counts that I can't tell you that, I can tell you of my great joy in reading, after I returned to Paris, the extremely laudatory sketches of my life."

At the Boston meeting the year before, it was decided to hold the next Zoölogical Congress at Gratz. Professor von Graff of that city, who was present at Boston, had been made President. Now, in Paris, at the Lamarck fête, there was a formal luncheon that was largely attended by prominent Frenchmen 


\section{FIGHTING THE INSECTS}

as well as by the foreign delegates. I was invited to sit at the head table, but declined, wishing to sit by my friend, Dr. Paul Marchal, in a less conspicuous seat. When the tables were filled, I noticed at the head table a man whose face was very familiar, but whom I could not place. I asked Marchal who he was, but he could not tell me, so I turned to the strange Frenchman on my right and said to him in French, "Can you tell me the name of the man at the head table between Perrier and Blanchard?"

"Ouit," he replied, "c'est evidemment M. Hovard de Washington."

I was of course in a position to assure him that he was mistaken. And there the matter rested until a month later, at Cambridge, I met Dr. von Graff one night at Sir Arthur Shipley's chambers. I recognized von Graff at once as the man I had puzzled about in Paris, and told him the story. His reply was characteristic and pleased me greatly. He said, "Vell, vy not? Ve are de same age, ve are de same size and wir sind beide lustige Männer."

The next month the celebration of the birth of Charles Darwin was held in Cambridge, England. It was enthusiastically described in many publications at the time. I not only enjoyed it thoroughly, but I was greatly impressed by the genius of the English in arranging functions of that sort. Delegates came from all over the world. Darwin's sons and their families were present, and there were receptions and garden parties and many notable speeches. I was quartered in Christ College, on a corridor immediately opposite the chambers occupied by Darwin himself when he was an undergraduate. And I ate at the Commons. Thus, surrounded by the English University atmosphere, the American delegates of my generation were enor- 


\section{THE STORY OF AN ENTOMOLOGIST}

mously impressed. It is not generally understood in England that we Americans, who have been educated in general along English lines and who have read literally hundreds of English books, know England and its institutions very well indeed, even without ever having set foot in the country. And for a college-reared man to find himself in the midst of surroundings that he has formerly visualized in his imagination was a wonderful experience. I carried away many enduring impressions.

But these impressions, wonderful as they were, had little to do with entomology. The great Cambridge entomologist, Dr. David Sharp, reverenced by his fellow workers all over the world, was not in evidence. However, I had not gone to the celebration with any idea of adding to my entomological knowledge, although Charles Darwin himself, broad naturalist that he was, knew a lot about insects. In his youth he had been especially interested in beetles.

At this celebration I saw Dr. Arthur Shipley, whom I had met previously at the Cosmos Club in Washington. By 1908 he had become a person of much importance. He was very proud of his standing in America and of the fact that Princeton University had given him an honorary doctorate. At the time of the Darwin Celebration he was already Master of Christ College. He was a rather convivial man, had stunning chambers and entertained every night after the other functions. I remember that von Graff, looking around hirn at Shipley's one night, said, "Shipley, I now understand why you have never married. It is these wonderful chambers."

This is hardly the place for an eulogium of Shipley, but this mention of him brings up a host of charming memories. He had collaborated with George H. F. Nuttall in a study of malaria and the malarial mosquitoes in England, and was a 


\title{
FIGHTING THE INSECTS
}

very well-known parasitologist. He was a man of infinite humor and of very broad reading and general culture. His books and magazine articles are full of delightful tales. I have elsewhere ${ }^{1}$ quoted some lines that he wrote me on the back of an invitation he once sent me to dine with him at his club in London, and they are worth repeating. He said, "You may not have heard that the hookworm has recently been found in Cornwall. This suggests the following lines:

\author{
If Cornish saints worked miracles, \\ The Bishop of this Diocese \\ Would quickly rid the Cornish mines \\ Of Ankylostomyiasis.
}

The last time I saw dear old Shipley was after he had been knighted and had been sent during the World War to the United States as the head of a British commission, the purpose of which, as I understand it, was to give Americans a more accurate view of conditions and to hasten the entrance of the United States into the conflict. Although his health was poor, he made some capital speeches (I heard one of them at the New Willard Hotel). He died not long afterward.

In July, I9I2, the Royal Society of London celebrated its two hundred and fiftieth anniversary, and invited the principal universities and scientific organizations of the world to send delegates. By great good fortune, I was appointed the delegate of the Washington Academy of Sciences. There were about three hundred foreign delegates in attendance, twenty-four of whom came from the United States.

The Royal Society of London is the oldest scientific society

${ }^{1}$ History of Applied Entomology, p. 485 (Smithsonian Pub.). 


\section{THE STORY OF AN ENTOMOLOGIST}

in Great Britain, and one of the oldest in the world. On Monday night, July 15, 1912, exactly two hundred and fifty years from the date of the passage of the Charter by the Great Seal, Burlington House in Piccadilly, famous during the previous sixty-five years for the notable social and scientific functions of the Society, was brilliantly illuminated, and the delegates there assembled, many of them just from their steamers and trains, for the purpose of registration and for informal meeting and renewal of acquaintance.

The first formal function took place the next morning, on Thursday the sixteenth, at Westminster Abbey. The heat of the day was excessive. It would have been bad even in Washington, and in London it was overpowering. The majority of the delegates wore academic dress, and the service was attended by many distinguished Englishmen high in rank or in political service. One of the naves of the cathedral was reserved for delegates, the remainder of the space being filled by London Society. Addison's superb hymn, "The Spacious Firmament on High," was sung by the choir. While this hymn was undoubcedly appropriate to the occasion, I think most of the American delegates smiled when the words were chanted:

Th' unwearied sun from day to day

Does his Creator's power display,

And publishes to every land

The work of an Almighty Hand.

The service was impressive, and most significant was the short address of the Dean of Westminster, based on the passage, "But Truth abideth and is strong forever." He recalled the perturbation that was wont to take possession of men's minds during the last century with regard to discoveries made in natural science-perturbation which sometimes betrayed it- 


\section{FIGHTING THE INSECTS}

self in fear, impatience and indignation. But these times were now changed, and he thought that he might claim to speak in the name of the whole world of Christian thought when he gave expression to the gratitude that, as a rule, the clergy has little or no opportunity for offering, to the amazing enrichment of human thought which had resulted from patient researches into natural science during the past two hundred and fifty years, and in particular in the past eighty years. He thanked God in their name, for the great and glorious work that had been done by men of science, for the widening of human thought. With all humility, he expressed their grateful acknowledgment for the benefits which had been rendered in Great Britain by the Royal Society.

In the afternoon of Tuesday, delegates were received in the great library of the Royal Society, Burlington House. Sir Archibald Geikie, the president, was accompanied by Lord Rayleigh, vice-president, and the officers. Most of the delegates wore official robes or academic dress. Among the doctors' gowns were prominent the crimson and gold cloaks of some of the German professors, the scarlet and gold uniform, with brown fur cloak, of an Hungarian delegate, the inconspicuous but rather bizarre olive green uniform of members of the French Academy, and the silk robes and turbans of the Indian representatives. The heat again was almost overpowering, and although the room is called "The Great Library," the delegates were so closely crowded that it required the intense interest of the function to overcome the feeling of personal discomfort.

Elaborately prepared and beautifully bound credentials were presented in order by the delegates of the countries represented.

I remember now with especial interest that when Germany was called, twelve men of academic appearance marched down the central aisle, followed by workmen carrying a great bronze 
plaque to be inserted in the wall of Burlington House. The inscription bore testimony not only to the great admiration of German men of science for English men of science, but of Germany for England, and stated further that nothing could ever disturb their most friendly relations. This was only two years before the outbreak of the World War. It is a curious fact that the famous "Manifesto of the Intellectuals," which was sent out by German professors in the autumn of 19I4, and which insisted that Germany was attacked on all sides and was only defending herself, was signed by every one of the twelve German delegates to the Royal Society Celebration of 1912. I received one of these manifestos from a German colleague, and am keeping it largely in memory of this incident.

The galleries of the great hall were filled with beautiful English women in colorful summer costume, and the whole scene was of the greatest charm. Although I am writing this in Paris in 1932, I can see it before my eyes as though it were yesterday.

On Tuesday night a banquet took place at the Guild Hall. The delegates were all present, as well as hundreds of men prominent in most walks of life in England. Whenever one glanced around the assemblage, his eye fell upon some man of world-wide fame. At the conclusion of the dinner there was an extraordinary list of toasts. I was impressed again by the different significance of the word toastmaster in England. In the United States the toastmaster is an important functionary. He may be very good, but usually he is very bad. He is often too long-winded, and we have all known him to make the speech which we expected from the speaker on whom he was calling. In England, however, the toastmaster is literally an announcer of toasts. In other words, the business of the toastmaster is simply to toastmaster. On this occasion he was a 


\section{FIGHTING THE INSECTS}

very large man with a very large voice, who at the request of the presiding officer, announced in stentorian tones the toasts that were to be drunk, always beginning "My Lords and gentlemen."

A notable speech was that of Mr. Asquith, then Prime Minister of England. It was historical in large part. One sentence which aroused laughter was as follows: "When the universities were engrossed in the din of civil war, 'to the neglect,' as a contemporary writer says, 'of academical studies,' science and philosophy took refuge in the comparative peace and tranquillity which the streets of the city of London could then afford." Another pleasantry of the Prime Minister's was as follows: "In the same rôle with John Dryden is one of the chief victims of his satire, George Villiers, Earl of Buckingham, who, amid his various qualifications for the chief office of state, was, as you know, 'chemist, fiddler, statesman and buffoon,' and I see from your records that history tells us that when this, perhaps the most original of the original Fellows of the Royal Society, was committed to the Tower, a special laboratory was fitted up for him in order that he might practise chemistry, and, according to Bishop Burnet, he was very successful in discovering the Philosopher's Stone-an illustration which suggests that some people might be more profitably employed at present than in either Westminster or Whitehall."

Characteristic of the address of the Prime Minister was the frank acknowledgment of the benefits derived by government from the work of men of science. He said very gracefully that the administration of the grants of the Royal Society is not so much a benefit conferred on the Society by the State as a service rendered to the State by the Society.

The distinguished scholar and eminent politician, Lord Morley, gave a most scholarly and able speech after proposing a [202] 


\section{THE STORY OF AN ENTOMOLOGIST}

toast to universities at home and abroad. I was also greatly impressed with a speech made by Mr. Balfour, and by the talk given by the Archbishop of Canterbury. I have forgotten the subject of Mr. Balfour's toast, but that of the Archbishop was "The Learned Societies in the Old and New World." $\mathrm{He}$ was delighted that this toast had been entrusted to an ecclesiastic. He called his hearers' attention to the fact that Smithfield and St. Paul's Cross were very near to the Guildhall, and he remembered to have heard that there was once a great gathering of orthodox ecclesiastics under that roof, or the one that preceded it, together with certain adventurous students of science, who might have been on their way to Smithfield that the one group might see the other suffer.

There were many other striking functions. The Duke and Duchess of Northumberland gave a garden party at Syon House, and one of the famous conversazioni of the Society took place at Burlington House. But probably the most striking of them all was a garden party at Windsor Castle, where the members of the Society and the delegates were received by Their Majesties, the King and Queen. The delegates were grouped according to countries, and passed Their Majesties in single file along the Rose Terrace. The garden party that followed this reception was attended by nine thousand of England's best. It was a beautiful day, the weather having grown cooler. The wonderful green of the English trees and turf, the brilliant colors of the summer costumes of the women, the variegated refreshment marquees, the stirring strains of several military bands, the sound of the charming English voices as they passed from group to group, the feeling that one had that he was mingling with the best that England could produce in culture, attainment and social position-all these together produced an exalted condition of mind not to be forgotten. 


\section{FIGHTING THE INSECTS}

I have mentioned only a few of the many strikingly interesting things connected with this celebration. On other occasions I had appreciated the genius of the English in the organization of scientific meetings and international congresses and celebrations, but never before had I met with such perfection of arrangement and such cordial hospitality.

A little later, in 1912, the Second International Congress of Entomology was held in Oxford, England, under the presidency of Professor E. B. Poulton. The entomologists had held an international congress two years before at Brussels, at the time of the International Exposition. I had been in Europe in 1909, but for some reason I was unable to leave Washington in rgro. However, I could not miss this one in England. In the early summer I had been in many European countries, and in late July I found myself in Brussels, visiting Professor A. Severin. I remember that Horvath of Budapest dined with us on his way to the Congress in England, and I remember also, with great distinctness, the stormy passage from Ostend to Dover in company with Severin and Ball.

The big, genial and learned Poulton was an ideal presiding officer, and naturally the English entomologists turned out in force. One of the leading members of the Committee on Organizations was G. B. Grosvenor, a young man of brilliant promise, who the year before, had been a Carnegie student in the United States. We who knew him prophesied great things for his future, and those of us who had the future of applied entomology at heart were much encouraged as we thought of his possibilities. But after the Congress he went to the seaside and was accidentally drowned.

As I had been at the Cambridge celebration four years before, I was quite prepared for the Oxford atmosphere. The wonderful 


\section{THE STORY OF AN ENTOMOLOGIST}

Hope Museum, over which the venerated John Obadiah Westwood presided for so many years, attracted many of us even away from some of the sessions of the Congress.

A very encouraging feature to me was the first meeting of the section on applied entomology. Practically down to that time the so-called economic entomologist, devoting himself almost entirely to agricultural entomology, had been considered by the university laboratory men, by the museum men, and by the amateurs interested wholly in Taxonomy, as a sort of farmer, with nothing like the same scientific standing as themselves. I think that there had been no section on applied entomology at Brussels, and I believe that this was the first time the experiment had been tried. I had been named as the chairman of the first session of this especial section, and I entered the meeting room with a fear that the speakers would have no audience and that their papers would not be discussed. My fears, however, were unjustified. The group was large, and no section had a better attendance. I am inclined to rate the Oxford Congress as a high point in the progress of applied entomology in the esteem of other branches of science.

I recall the final dinner with especial pleasure. Many excellent speeches were made. It was announced that the next congress would be held in Vienna, and that Anton Handlirsch would be president. Handlirsch, delightful man that he is, sat at Poulton's right, and in response to the applause following the announcement made a charming little speech in German.

But the Vienna Congress was never held, for in the summer of 1914 Vienna was in almost a volcanic condition. In fact, the Fourth Congress did not take place until thirteen years later. Apropos of the interrupting, catastrophic war, I recall that at the Oxford meeting, Poulton unexpectedly called upon me to make some remarks, and that I fancifully said that we 


\section{FIGHTING THE INSECTS}

were all brothers there, that we were not English or French or German or Austrian or Russian or Italian, but that we belonged to the World Nation of Entomologists. And yet two years later the very nations I mentioned were in desperate conflict.

It was long after the close of the war that peaceful international scientific congresses, attended by delegates from the former battling nations, were resumed. One of the first of these was the international conference of phytopathologists and economic entomologists that was held at Wageningen, Holland, in 1923.

There were present at this congress delegates from nearly all of the countries that had been at war. We were naturally curious to see whether there would be any stiffness or any change in mutual attitudes as a result of the previous violent national feelings, but everyone seemed determined to ignore the past, and to act as though the events of the period between I9I4 and I918 had never occurred. I think, however, that the eyes of each of us were rather keenly watching for the minutest signs of discomfort on the part of the others. I thought I noticed that the Germans were rather on the defensive at first. I saw signs which indicated that they did not know exactly how they would be received and treated, though they were friendly enough and seemed ready to meet the others in a whole-hearted way. This sensitiveness soon passed away, and most of them assumed their old pre-war-time manner.

Socially and scientifically, this Wageningen Conference was a great success. The delegates were royally entertained, and taken from one point to another through the wonderful bulbgrowing districts of Holland. Many speeches were made by prominent Dutch officials, and, as I have stated before, much indignation and regret was expressed at the action of the United States government. The American delegates were fre- 


\section{THE STORY OF AN ENTOMOLOGIST}

quently called upon to speak after addresses of this sort at dinners and luncheons, but of course all that we could say was that while we sympathized deeply with the Hollanders, we had no influence whatever, always making the general statement, however, that we believed that any nation had the right to protect itself by quarantine against plant enemies and diseases, just as it had the right-just, in fact, as it was its dutyto quarantine against human diseases.

At the last meeting of this conference a permanent organization was established and representative committees were appointed, with the idea that future international conferences of the sort would probably be called.

There was much discussion as to the name of the new organization. In the original call it had been termed an International Congress of Economic Entomologists and Phytopathologists. In most European countries, and in certain others, the term Phytopathology is held to include the damage done by insects to growing plants, and it has often resulted from this use of the term that botanists have been placed in charge of entomological work. We in America can see no reason why an insect should be called a disease of plants, or why two services requiring such different technique and training should be combined under a single misleading term. So when the motion was made to omit the words economic entomologist, and when later some of the delegates, especially the Germans, proposed to compromise by adopting the words Plant Control (Pflanzen Schutz), we opposed both suggestions, and, with the important help of the English delegates and some others, we carried our point.

It may be stated incidentally that later we were able to do away with the European acceptance of Phytopathology as including Agricultural Entomology in the nomenclature used 


\section{FIGHTING THE INSECTS}

officially by the International Institute of Agriculture at Rome.

During that same summer of 1923 I attended two other international gatherings. The first was held in Madrid in May, under the auspices of the International Institute of Rome, and it was held solely for the purpose of considering the measures to be taken against the olive fly, a very injurious insect that often causes great loss to the great olive industry that centers in the countries about the Mediterranean Sea. The United States had been asked to send delegates, but had refused on the grounds that the olive industry in the United States was comparatively small, existing only in Southern California, and that the olive fly was unknown in our country.

I am reminded here of an interesting story bearing on these facts. A good many years ago Secretary of Agriculture James Wilson sent for me and told me that he had dined at the White House the night before, and that the lady on his right, the Principessa Brancaccio, had told him that she had asked to be seated next to him, for the reason that her husband's olive groves in South Italy were badly infested by the olive fly, and that she, knowing how practical the Americans are in such matters, had come to America largely to consult him about it. He told her that he was not an entomologist, but that he would send some one to her to talk about it the next afternoon. He placed his carriage at my disposal, gave me a card of introduction, and I went out to the beautiful house at the corner of Twentieth and Q Streets which the Prince and Princess had leased for the winter. The Princess was both beautiful and intelligent. When I asked the exact location of her husband's olive groves, she stated that they were in Portici, just outside of Naples. I then told her that the fly did not exist in the United States, and that the expert who knew most about it and the way to control it was Professor Antonio Berlese, of 


\section{THE STORY OF AN ENTOMOLOGIST}

the Royal School of Agriculture at Portici, which immediately adjoined her husband's property.

Although the United States, for the reasons before mentioned, declined to send delegates to the Madrid Conference, I found myself, just before the date of convocation, in the south of France, in company with Dr. Paul Marchal of Paris, who was to represent the French Department of Agriculture at Madrid. I am a great admirer of Marchal, and greatly enjoy his company. Then, too, the subject of the conference interested me, because some day this noxious little fly may make his way to Southern California. So I went with Marchal to Madrid.

The conference was very interesting and was attended by delegates from practically every country bordering the Mediterranean. My old friend Il Conde de Montornes presided, and the discussions were all in the French language. Certain purely scientific sessions were presided over by Dr. Marchal. The only technical delegates at the conference whom I had met before were A. de Seabra of Lisbon and Leandro Navarro of Madrid, but I took the opportunity to visit the splendid Museum of Natural History, and to have a long talk with the veteran Ignacio Bolívar and his son, Candido Bolívar y Peltain and with Ricardo Garcia y Mercet, who had done, and is doing, admirable work with certain groups of parasites.

During the olive fly discussions, the question of mechanical sprays was introduced, and it was stated that large scale-spraying by great machines would be most difficult in the majority of olive orchards because of the hilly character of the terrain. I was asked to explain how spraying was done in mountainous districts in New England in the work against the Gipsy Moth. Marchal had been over this ground with me in Massachusetts and southern New Hampshire in the summer of 1913. I told them not only about the spraying from great ground machines 


\section{FIGHTING THE INSECTS}

but also about the use of the aëroplane-a method which was proving effective both in the cotton fields and in forest insect operations.

I think that it was in August, I923, that the International Congress of Agriculture was held in Paris. As I was over there at the time, I naturally attended it, registering as an official delegate from the United States Department of Agriculture. Several other Americans who had been with me at Wageningen the month before also attended this conference.

The closing banquet was held in one of the great halls of the Hôtel Continental. The Marquis de Voguë presided with great ability, tact and charm, and many of the speeches were admirable. I had been notified that I would be expected to say something, and therefore I had written out a short speech. I had protested to the Secretary of the Académie d'Agriculture, the late Henri Sagnier, that I would have to make my remarks in English, but he insisted that I should speak in French, so I asked Paul Marchal to transcribe what I had written, turning it into his beautiful French, and this I memorized and delivered. The reason I tell this is so that I may add that I sent a copy of my remarks to Washington as a part of my official report. I received a personal letter from the then Secretary of Agriculture, Henry Wallace, who was a good deal of a wag. He thanked me especially for sending it in French, and said that I probably thought that this would puzzle him, but he assured me that he was quite as familiar with the French language as he was with his native Sanskrit.

I will speak a little later of the Pan-Pacific Union, a remarkable organization, originating in Honolulu and having its headquarters there. 


\section{THE STORY OF AN ENTOMOLOGIST}

In the summer of 1924 a Pan-Pacific Conservation Congress was held in Honolulu under the auspices of this Union, and delegates were present from most of the countries bordering the Pacific Ocean. Several of us went on from Washington as delegates from the United States Department of Agriculture, and other men went from different States, especially from those of the Pacific coast. Since conservation was the object of the Congress, the economic entomologists were well represented, and, although no one seemed to know just why, I was made first temporary, and then permanent, president. There were in attendance some extremely interesting men from Japan, China, Australia, New Zealand, Indo-China, the Dutch East Indies, Macao and other places, but, as I recollect, the Pacific coast of South America was not represented. The Congress was in session a little more than two weeks, and there were some highly noteworthy papers and discussions. Although on the whole the proceedings were harmonious, there were dissensions among the representatives from North China and South China, and at one or two of the functions the Japanese delegates were not treated by the prominent Korean citizens of Honolulu with much courtesy.

The late David Starr Jordan, President-Emeritus of Stanford University, was there with his charming wife and his talented son, Eric, who was killed in an automobile accident the following year, almost immediately after his marriage. A notable delegate was Sir Joseph Carruthers, former Premier of New South Wales. Dinners and luncheons were given almost every day by organizations from different nationals living in Honolulu, and quite naturally Dr. Jordan, as well as Sir Joseph, who proved to be an extremely witty after-dinner speaker, were called upon nearly every time.

I shall never forget how Sir Joseph turned the laugh on [2II ] 


\section{FIGHTING THE INSECTS}

me at one of these functions, given by the Chinese community. The presiding officer was Mr. Wang How, a dignified and impressive Oriental who made what was apparently a cordial and eloquent address of welcome. But he spoke in Chinese. As President of the Congress, I was called upon to respond. I complimented Mr. Wang How upon his remarks (of which I had not understood a single word) and spoke with admiration of the wonderful Chinese nation, of its marvelous history, and its wonderful inventions, referring, of course, to the discovery of gunpowder and the mariner's compass, and went on to demonstrate that the Chinese had been inventive in little things as well as big ones.

"For example," I said, "take the name of the distinguished Chairman, Mr. How. That happens to be the first syllable of my name, therefore my family must have originated in China." And I therefore greeted Mr. How as a long-lost relative.

After I had taken my seat, Sir Joseph was called upon. He began by saying that he was much interested in what I had said, but that he had anticipated me in my discovery of my relationship to Mr. How, since he had noticed the facial resemblance between us as we sat almost side by side at the head table!

My opening address as Chairman of this Conference was called "The Evolution of Internationalism"-the one referred to in the first paragraph of this chapter. I enjoyed writing the address and in thinking about the general subject. It was published locally, and was printed in full in the American journal Science. I thought that it would be a good idea to send it about a bit, and in doing so I had an interesting experience. I sent a copy to my friend Paul Marchal, in Paris, and asked him to hand it to the late Henri Sagnier, Permanent Secretary of the Académie d'Agriculture, for possible republication by 


\section{THE STORY OF AN ENTOMOLOGIST}

the Academy in French (a translation having been made by Dr. Marchal). Sagnier refused on the ground that the word "Internationalism" was altogether too suggestive of "Moscovietism." Whereupon Marchal took it to the editor of Le Revue Scientifique, where it was published in full with a somewhat modified title. ${ }^{1}$

In 1925 , I went to Europe with the purpose of attending three international gatherings, although I suppose the first could hardly be called international. It was the triennial meeting of the Imperial Bureau of Entomology of Great Britain, but it seemed almost international, since it brought together the official economic entomologists of the different British dominions and colonies. As a matter of fact, I believe I was the only foreigner invited. After the London Conference I was to have gone to the International Congress of Agriculture at Warsaw, and later to the Third International Congress of Entomology at Zürich. But I had a bad accident on shipboard, which resulted in compressed fractures of two vertebræ, and I was held in a Nursing Home in Glasgow so long that I missed the meetings at London and at Warsaw. But the Glasgow stay was delightful. Dr. R. Scott Frew and Dr. Archibald Young, who attended me, were kindness and skill personified. Miss Cameron, the head of the Nursing Home, was a charming Scotch lady, the nominal head of the Clan Cameron, I was told. I fell quite in love with five of my Scotch nurses. Since then I have never allowed anyone in my presence to slur Scotland, and I even listen with distaste to stories of Scotch frugality.

After a good rest, I was able to travel again. I went to

1 "L'Evolution des Rapports Internationaux," Retue Scientifique, Vol. 62, No. 24, pp. 753-754, December 27, 1924. 


\section{FIGHTING THE INSECTS}

London, then to Paris, and on to Zürich, where I met old friends and made new ones.

The Zürich Congress of Entomologists was large and enthusiastic, and I was not surprised, but very glad, to find that once more there was an increase in the interest in applied entomology. This was shown not only by the character of the papers, but by the increased attendance at the meetings of that section.

In 1927, having to go to eastern Europe (Poland, Czechoslovakia, Germany, Austria, Hungary and Jugoslavia) on an official mission, I took credentials from the Biological and Entomological Societies of Washington as a delegate to the International Congress of Zoölogy that was to be held at Budapest that summer. Here again there was abundant evidence that there was a great increase of interest among the scientific men in questions of applied zoölogy, and especially applied entomology. It was a great congress. The president, Dr. G. Horvath, already eighty years of age, was an entomologist, and during the days of the Phylloxera scare had done important work of a distinctly economic character. One of the most interesting of the general lectures was given by Professor Komarek of Prague on the airplane dusting of great spruce forests in Czechoslovakia against a disastrous outbreak of the Nun Moth. Then, too, the first session of the section on economic zoölogy (I was the chairman) was largely attended, and it was noticeable that nearly all of the papers read at this session and at subsequent meetings of this section were of an entomological nature. The final dinner, given at a great new hotel across the Danube, was attended by more than a thousand guests, and was one of the most brilliant functions of the kind that I have ever attended. 


\section{THE STORY OF AN ENTOMOLOGIST}

In 1928 the Fourth International Congress of Entomology was held at Ithaca, New York. The Zürich Congress of 1925 had selected the United States as the country for the 1928 Congress, had elected me president, and had left the choice of the exact locality to a small committee of Americans. We discussed the availability of New York, Boston and Philadelphia, and finally decided upon Ithaca, not only because that place is easily reached from the seaboard, but because the buildings of Cornell University are wonderfully adapted to the holding of big congresses in the summer time, as had been demonstrated the previous year at an international congress of botanists. Then, too, it was judged that the temperature in August at Ithaca would probably be somewhat lower than that at Philadelphia or New York. Pittsburgh had also been considered as a meeting place, largely on account of the existence there of the great Carnegie Museum, of which the distinguished entomologist, Dr. W. J. Holland, had so long been the director.

Although the weather was very warm on some of the days of the meeting, the Congress was a great success. The Americans, especially the Cornellians, had reason to be proud. Undoubtedly the experience of the previous summer with the Botanical Congress had made the local people more efficient in their arrangements than they might otherwise have been, for it is impossible to point out a single point in which they failed. All of the foreign delegates left in a very enthusiastic frame of mind. There was a large attendance of entomologists from the United States and Canada, as was to be expected, and it was the first international gathering that many of these men had seen. I think that nearly all of them left Ithaca with the firm resolve that they would never miss another international congress. This is one of the many proofs of the international value of such gatherings, of their helpfulness in bringing about 


\section{FIGHTING THE INSECTS}

understandings and their aid, although, it must be admitted, in a small way, toward the world peace that must come eventually.

In addition to these international affairs away from home, I have attended a number of such functions held in Washington, and in a very few of them have taken a small part. For example, at a Pan-American Health Congress held in one of the early years of the present century, I spoke on the geographic distribution of the Yellow Fever Mosquito. It was at this congress that I first met Dr. Carlos Finley of Cuba, who was accompanied by Dr. Juan Guiteras, and then also for the first time I met Dr. Eduardo Liceaga of Mexico. All these men have been mentioned in previous pages. I think that this meeting must have been in 1903. It was at this Congress that a reception was held by President Roosevelt that I shall mention in another chapter.

Later there was another Pan-American Congress, this time a scientific one, and at this I addressed one of the sections on the necessity for coöperation among the American nations in the warfare against insect pests.

In 1912, while I was returning from Europe, where I had attended the two hundred and fiftieth anniversary of the founding of the Royal Society at London, and the Second International Congress of Entomology at Oxford, I met in the smokingroom of the steamer, Dr. Zort, late Surgeon-General of the Baltic fleet of the Russian navy, who was on his way to attend an international congress of hygiene and demography at Washington. It will be remembered that the ill-fated Baltic fleet started from Russia during the Russo-Japanese War, and after supposedly firing on the British fishing vessels in the North Sea, made its way in time to Chinese waters, and there was 


\section{THE STORY OF AN ENTOMOLOGIST}

destroyed by the Japanese fleet. Dr. Zort told me that he had been picked up in the water by a Japanese rescuing boat and had been carried to Japan, where he received the most extraordinary courtesy. He was not only allowed to care surgically for his own compatriots, but was invited professionally to attend many major operations. On the transatlantic vessel at the same time was Professor Fujisawa, the mathematician, whom I had met in London, when he was a delegate to the Royal Society function from the University of Tokio. I brought the two men together, and Fujisawa countered Dr. Zort's stories concerning the courtesy he received in Japan by telling us of the extraordinary courtesy that he had received in Russia on his way across country from Japan to England.

Dr. Zort was a big man, convivial and companionable to a degree. I put him up at the Cosmos Club on our arrival at Washington, and one night, when I visited the Club, I found him in the library, where he had found a book entitled, "The Bartender's Guide," and was engaged in copying the recipes for rather more than fifty different kinds of cocktails.

The last one of these international gatherings that I have attended down to the present time was the recently completed Fifth International Congress of Entomology held in Paris. But this chapter is already too long, and I shall add something about the Congress in the very rambling final chapter. 


\section{Chapter XI}

$T_{\text {HE American Association for the Advancement of Science }}$ was founded in the early $185^{\circ}$ 's, some years before I was born. Its organization was based on that of the British Association for the Advancement of Science, and it has had a long and useful life. Its annual migratory meetings were interrupted by the Civil War, but only for two or three years, and its presidents (elected annually) have included many of the men who have been most prominent in scientific work down to the present day.

It was soon found that a permanent secretary was necessary. Professor Joseph Lovering of Cambridge was the first one. He was succeeded, in the early $1870^{\circ}$ 's, by Frederick W. Putnam of Salem, who held office by reëlection every five years until 1898 . At that time he was getting old, and there was a feeling that the Association was getting into a rut and was not increasing either in size or in usefulness, so it was thought best to look for another man. At the meeting held in August, 1898, at Detroit, Michigan, rather to my surprise, I was elected permanent secretary. I was glad to have the office, since it brought me into contact with scientific men all over the country, and also added somewhat to my small income. I held the office with 


\section{THE STORY OF AN ENTOMOLOGIST}

more or less success for twenty-two years. Looking back, it seems rather sure that no other experience could have been better for me in broadening my scientific outlook, and that in making the contacts which the position afforded, it helped the Federal service in which I was engaged. For the next twentytwo years the annual meeting was held in some city (usually at a university), and these migrations covered the whole country. The association included among its members nearly all the active working scientific men of the country, as well as a great number of others interested in science or who wished to become patrons of science in a small way.

Many incidents connected with these meetings come to my mind, and some of them may be told.

After the Detroit meeting in 1898 , a large number of us went on to Toronto, where the annual meeting of the British Association for the Advancement of Science was held during the week following our meeting. The Toronto gathering was a decided success. The meetings of the British Association have always been more brilliant socially than ours. The Governor General of Canada, Lord Aberdeen, was much in evidence, and many distinguished men had crossed the Atlantic to be present. Lord Kelvin and Lord Lister were there, as well as Sir John Evans, the president of the Association for that year, and many others of scarcely lesser note. As the newly-elected permanent secretary of the American Association, I was given a seat on the platform with the dignitaries at the public lectures. It was in August, and it was very hot, so, ignoring form, I wore my straw hat to these evening functions with my dinner dress. On leaving the platform after the first lecture, I found myself touching elbows with no less a person than Lord Lister, and to my great joy I saw that he also had a straw hat. I told him that I was much relieved to see this, and he put his arm around 


\section{FIGHTING THE INSECTS}

my shoulder and said in that utterly charming way of his, "My dear boy, it's not what's on your head that counts; it's what's in it!"

At the final banquet I was much impressed by the opening words of Sir John Evans' remarks. He said, as I remember it, "If it be given a man to write his own epitaph, I should like to word mine now: 'Here lies the body of Sir John Evans, who had the great honor of presiding over the Toronto meeting of the British Association, and who, during his lifetime, did a little toward the establishment of archæology as a science." Down to that time it had never occurred to me that any archæologist had ever considered his pursuit as non-scientific.

At this Toronto meeting I had my first introduction to the "Red Lion Club" of the British Association. This club is, or was, composed of the convivial members of the association, and at each meeting it was their custom to give a dinner at which there was all sorts of fun (a corresponding organization in the American Association for years was known as "Section Q"). At the Red Lion dinners all of the members were supposed to be lions. There were two or three ushers, known as jackals, whose wands of office were representations of human thigh bones, made of wood, but colored with red paint. It was not permitted to laugh, but the lions were expected to roar. At every dinner certain new men were initiated as cubs. At this Toronto dinner there were twelve Americans, and it would have taken too long to initiate each one separately, so a single one was chosen to personify the dozen. This happened to be General A. W. Greely, the Arctic explorer. The King Lion who presided was Professor MacAlister, the mathematician of the University of Dublin. He said, "I shall not only initiate General Greely into the mysteries of full-blown Red Lionship, but I will in addition confer upon him the degree of D.D." 


\section{THE STORY OF AN ENTOMOLOGIST}

(Loud roars.) "You seem surprised that I should confer this particular degree upon this man, and I will explain that it is because, although he did not reach the North Pole, he came d-d near to it."

I could go on for many pages with stories of the funny things that happened at these meetings. For instance, in 1905, we were meeting at New Orleans in the winter time. The city had recovered from what in June bid fair to be a serious epidemic of Yellow Fever, but which had been controlled and finally stamped out by well planned and conducted anti-mosquito operations under the efficient guidance of Dr. J. H. White, of the United States Public Health Service. During the meeting the officers and members of the Boston Club gave a smoker in honor of the officers of the Association. In the course of the evening there were three speeches. Dr. H. W. Wiley was called upon, of course. He was inimitable, as usual. I remember that he called attention to the fact that the city of New Orleans was largely built on soil that must have been brought down far from the north by the great Mississippi River and its tributaries. He went on to say that his father's farm was in southern Indiana, on the banks of the Ohio River, and that much of the farm had been washed away in the course of years. He felt sure that the soil from his father's farm formed the base on which the St. Charles Hotel was built, but that he had decided not to enter suit against the hotel or against the city for damages.

Then, since I was permanent secretary of the Association, I was called upon. I told a little story to this effect: One day at my office I was called to the telephone, and the man at the other end of the line announced that he was a Post Office inspector and wished me to come to see him at once. I asked for some reason, but he replied in a mandatory way that I must 


\section{FIGHTING THE INSECTS}

come immediately. And so I went. He proved to be a large, florid, important-looking person, and he said, somewhat with the air of a justice of a police court, "Mr. Howard, you are supposed to be the secretary of" (consulting some papers) "an Association of the name of the-ah, yes, here it is-the American Association for the Advancement of Something-or-other."

I said, "Yes."

"Tell me something about this organization," he demanded. "Has it any standing? Is it well known? Is it a new thing that you are trying to promote?"

"No," I replied, "it was founded fifty years ago."

"How many members has it?"

"Nearly two thousand," I told him.

"Has it any members in Washington?"

"Yes," I said; "very many."

"Tell me the names of some of them."

"Well," I said, "there is Professor S. P. Langley of the Smithsonian Institution; Professor Simon Newcomb, the head of the Naval Observatory; Professor Alexander Graham Bell, the inventor of the telephone; Chief Justice Fuller of the Supreme Court of the United States___."

"Hold on," he said. "That'll do. It really seems to be a rather meritorious organization," he added in a patronizing way, and then went on: "You see, it does beat the deuce how suspicious some people are! A man up in New Jersey received a notice from you stating that he had been elected a member of this Association and asking for five dollars' entrance fee. He immediately notified the Post Office that this was another fraud, and the case was assigned to me for investigation."

That evening I looked up the case and found that the man had been proposed for membership by a prominent professor in Princeton University. 


\section{THE STORY OF AN ENTOMOLOGIST}

Wiley's remarks and mine were well received, and then a local man, James J. McLaughlin, was called on. He was evidently a man of standing and culture, but to the surprise of us visitors he spoke in a strange dialect that we were told was Acadian ("Cajun" they call it down there). It seems that he was impersonating a mythical individual whom he had made locally famous and who was a native wit. He put into the mouth of this mythical person a sparkling series of comments on the remarks that Wiley and I had made, and upon the Association and its proceedings, mispronouncing and misinterpreting any number of scientific words and phrases that he had read in the newspapers in the preceding few days. His speech was an overwhelming success. The local members of the Boston Club had a hearty laugh at our expense, and we ourselves enjoyed it immensely.

At a meeting held in Denver, Colorado, in the early part of the present century, I first met John Hayes Hammond. He called at my office in the Brown Palace Hotel, told me that as at that time he was a citizen of Denver, he wished to do his share towards the entertainment of the Association, and asked me to invite twenty-five men of my own selection to dine with him at the Denver Club. I accepted the commission willingly, and picked out a rather famous company. I remember that W J McGee was one of them. When I asked him he said, "Of course I'll come. They have mighty good dinners at the Denver Club. But who is this man Hammond who's to be our host?"

"Why," said I, "don't you know? He is the famous mining engineer whose exploits have been in every one's mouths. He is the man who was carried across Mexico in a coffin to escape assassination. And have you forgotten that he is the American engineer who accompanied Jameson on his disastrous raid in the Transvaal?" 


\section{FIGHTING THE INSECTS}

"By George!" said McGee. "I would willingly pay a high price for sitting at the table with him."

I told all this to Hammond the next day, and he said, "Doctor, in view of the high standing of these men, I will reduce the price of introductions to, say, twenty-five dollars per."

As I have mentioned Hammond's name, I may as well tell one other story about him. Years later I was a guest at an engineers' dinner in Washington. Hammond was the principal speaker. His subject was "The Engineer in Politics," and he played up all the qualifications of the engineer-how he is the real man in big affairs, and how, of all citizens, his judgment is the best. Therefore, the engineer, for the good of the country, should go into politics and take a most active part. It was a good speech, and Hammond sat down probably well satisfied. At all events, the rest of us liked the speech extremely.

The man who followed him was Franklin K. Lane, then Secretary of the Interior, a delightful man and a famous afterdinner speaker. He smiled broadly at his audience, and said that he had been very much impressed by Mr. Hammond's speech, and was inclined to agree with him.

"But," he said, "back in my brain I think that, if I remember, the last time that $I$ heard of an engineer going into politics, he wound up in jail!"

Of course the Jameson Raid was fresh in our memories, and we all yelled with delight.

While there can be no doubt that this permanent secretaryship was a good thing for me personally, in ways that I have already pointed out, it must also have been beneficial to applied entomology, since it brought an entomologist into intimate association with workers in other branches of science, who were more highly esteemed by people at large, and it helped to show 


\section{THE STORY OF AN ENTOMOLOGIST}

them that an entomologist is not necessarily a confounded crank.

At all events, I made hundreds of friends, and many warm ones. When it appeared that my job might well be taken on by a younger man, the Council apparently had no hesitation in making me president of the Association. Of course this, too, helped to broaden the concept of an entomologist.

It is the custom of the Association to ask its president to deliver his retiring address at the meeting following the one over which he presides, and thus it happened that, although I occupied the chair at the meeting held in Chicago in the Christmas holidays of 1919, I gave my address at the meeting in Toronto, Canada, in the holidays of 1920-1921.

This mention of the time of the year when these meetings were held reminds me of another matter which should be mentioned. In the early days the annual meetings were held in August, following the plan of the British Association. Since this was during the long vacation, it was especially convenient for the professors in the colleges and universities and for the teachers in the schools. Moreover, although August in the States is not so distinctly the vacation month as it is in European countries, it is chosen by many people. But with the new century we made a change, and since that time we have held the annual meeting in the week which includes January $\mathrm{I}$. In order to bring this about we conducted a lengthy correspondence with most of the university people and secured the very general adoption of what is now called "Convocation Week," in which most of the learned societies now hold their meetings. Nearly all of the colleges and universities have arranged their Christmas vacation schedules so that their people may attend these meetings. The expression "Convocation Week" is now to be found in the later American dictionaries.

I remember that this idea originated in the old Committee 


\section{FIGHTING THE INSECTS}

on Policy of the American Association for the Advancement of Science. This committee had a rather interesting beginning. Before I was made permanent secretary, my predecessor, F. W. Putnam, conducted affairs in his own way, and there was a feeling that this was not quite right. So, gradually and very tactfully, Professor J. McK. Cattell and the late Professor R. S. Woodward of Columbia, as well as Professor Charles Sedgwick Minot of Harvard, formed themselves into an advisory committee and met frequently with me, thus constituting the beginning of the Committee on Policy, which lasted for many years, and of late has become known as the Executive Committee. Other members were added from time to time, but it was all done very tactfully-so tactfully indeed that I really supposed that I had something to do with it. As a matter of fact, I believe that $\mathrm{I}$ really did suggest the names of $\mathrm{W}$. J. Humphreys and H. B. Ward, who served on the committee for many years; and I readily welcomed H. S. Fairchild and D. T. Macdougal, who, I think, were suggested by Professor Cattell.

And now to go back for a moment to the Toronto meeting. I was treated royally, and was given the honorary degree of Doctor of Science by Toronto University. During my stay, I was the guest of Sir Reginald Falconer, the President of the University, and gave an address that was well received by the association. It was in this address, by the way, that I first pointed out in a somewhat strenuous way what I conceived to be the great insect menace, upon the subject of which I have recently written a book.

One of the interesting incidents of this Toronto meeting was the presence of Professor William Bateson of Cambridge University, who gave an evening lecture on some of the aspects of evolution. In this he incidentally spoke of the broadening of the concept of evolution and hinted at some of the weak points in 


\section{THE STORY OF AN ENTOMOLOGIST}

Darwin's famous "Origin of Species." As was quite to be expected, this point was seized upon at once by people of different sects, and the lecture was played up in the newspapers as a tremendous blow to the whole Darwinian hypothesis. Bateson was a delightful man-a tall old fellow with beetling gray eyebrows. He made an after-dinner speech at the annual dinner of the American Society of Naturalists, held during this Toronto meeting. He was the first speaker, and had not finished his cigar when he was called upon. He did not discard his cigar when he rose to speak, but would occasionally stop in the course of his remarks, and puff on it a bit. The next day, meeting him at a luncheon, I said to him, "Professor Bateson, some of us were a bit worried last night at the difficulty that you had in keeping your cigar going while you were speaking. In fact, one of us left the room immediately after your speech and spent the rest of the night trying to invent an apparatus by means of which an after-dinner speaker can smoke and speak at the same time."

The fine old chap beamed down upon me under his beetling eyebrows and remarked, "Fancy! What an extraordinary people you Americans are!"

I must say a little about that remarkable man, Charles W. Eliot. I met him first at the Boston meeting in the summer of I898. As President of Harvard, he very naturally made one of the principal addresses of welcome. I was not especially impressed by his personality, but I was by the great respect and affection which the Boston people apparently had for him. Most of them seemed to think that he could not possibly make a mistakethat he was all-wise. As an outsider and familiar only with the broad aspects of his career, I rather wondered at this.

During the World War there was some talk of abandoning one of the annual meetings on account of upset conditions. Travelling was difficult. Trains were fewer and were over- 


\section{FIGHTING THE INSECTS}

crowded, and many of the most prominent members were actively engaged in war work. But Pittsburgh offered itself as a meeting place and urged us to come. We finally accepted, and as Dr. Eliot had been elected president, largely since a new section of education had been established, I notified him of the decision. He wrote me that he thought it would be very unwise for him to accept. He was then seventy-nine years old, and the following year, when he would have to make his address as retiring president, he would be eighty. We used some sound arguments, and he finally accepted. I naturally saw much of him at the Pittsburgh meeting and during the following year.

When he arrived at Pittsburgh he was apparently in vigorous health. I asked him how he had spent the summer, and he rather startled me by replying that he had largely occupied himself with rowing and bicycling. He did his duty at Pittsburgh almost more than conscientiously, and introduced certain features that were new. He conceived it to be his duty as president to pay a visit to each one of the many sections-a capital idea, which I had seen carried out in the British Association for the Advancement of Science.

The new section of agriculture was founded at this time. Dr. Eliot attended the first meeting, and of course was called upon to speak. We were all in a state of great excitement about the war, and his remarks, beginning naturally with a consideration of the necessity for intensive agriculture in our country in the existing emergency, went on into other features of the great conflict. He was very bitter against the Germans and spoke at some length concerning the alleged Belgian atrocities that were then reported luridly in the newspapers. During his speech four German professors who, while they had not been interned here, had been caught in the United States and were unable to go [228] 


\section{THE STORY OF AN ENTOMOLOGIST}

home, rose from their seats, walked down the aisle, and left the room.

The newspapers said nothing about this incident since we had a very clever press secretary in those days (the Theodore Waters whom I have told about in a previous chapter), who conceived it to be his principal duty to keep certain things out of the newspapers rather than to see that certain other things got in. So this incident was covered up. But a day or so after the meeting Waters told the story to a little group of newspaper men with whom he had been associated. One of them-one of those newspaper chaps who think in headlines-said, "Gosh, Waters, why didn't you tell us? Oh, what a headline! 'And the Germans goose-stepped down the aisle while Eliot hurled denunciations at the Huns." "

I have said that I met Dr. Eliot for the first time at the Boston meeting in 1899 . That, I think, was the last of the August meetings of the Association, and it was a memorable one for many reasons. Since it was the first at which I officiated as permanent secretary, I have probably remembered the interesting and funny things more vividly. It was very hot at the time. There was a lobster salad served at one of the general luncheons, and that salad is still remembered by many members, who, through it, became acquainted with a rather mild ptomaine poisoning. One friend of mine always refers to it as "that lobster salad meeting."

Josiah Quincy was then Mayor of Boston, and he gave a dinner at the Union Club for a number of us. He sat at one end of the big table, and an interesting friend of mine and of his, E. A. MacDowell (a son of General MacDowell of Civil War fame), sat at the other. After dinner the Mayor introduced a famous French anthropologist who was a special guest of the association at the meeting. The Frenchman rose and began: "Zis morning I did spik to the Association in ze French, and I fear me they 


\section{FIGHTING THE INSECTS}

did not understand me. So tonight I will spik in ze English." Whereupon MacDowell at the other end of the table (or possibly it was Professor Sedgwick) sang out in a purposely villainous French, "Ici ong parle français," which caused a great laugh and confused the Frenchman, who nevertheless went on in somewhat halting English.

At this dinner I sat between Dr. Chadwick and the famous botanist Professor W. G. Farlow. They were great friends and had been fellow students at Harvard. They chaffed each other unmercifully and very wittily. I'd give a farm, if I had one, if I could remember some of the clever things that they said!

I became well acquainted with Professor Farlow afterwards. He was one of the most charming men I have ever known, and one of the wittiest. He was president of the American Society of Naturalists a year or so later. Their annual meeting was held at New Haven. Farlow invited me to come on and speak at the final dinner. As I remember the subject was "Zoölogy under the Government." It happened that the Society had been having a general discussion that afternoon on the topic of research in the universities, and I took my cue from that. But just before I began to speak one of the men whispered to me that although Farlow was an old bachelor, it had just been announced that he was engaged to be married. And so I began my remarks by asking the old conundrum: "Why does a married man live longer than a bachelor?"- -stating that it was apropos of something I had just heard about, and of course I gave the answer: "He doesn't. It only seems longer." And then I went on with my remarks. I referred to the afternoon discussion and said that many of the teachers regretted greatly that they had no time for research, and that very possibly they envied the government men for that reason. But, I pointed out, that while the government men apparently had all of their time for research, just as 


\section{THE STORY OF AN ENTOMOLOGIST}

soon as one of them showed any great ability he was put into an executive position, where he had to fritter away no end of time in the multifarious things demanded by the red tape of government. And so, I went on to say, the government men did not have the great satisfaction of having trained the early steps of some future great investigator.

I thought I had made a good point and sat down rather satisfied with myself. But Farlow, probably still resenting my reference to his engagement, said, "That is all very interesting, but I am sure that many of us here would be only too glad to turn over to Dr. Howard the training of the early steps of many future great investigators." This met with an instant response from the four hundred teachers present, who broke into hearty laughter at my expense.

A year or so later Farlow was president of the American Association for the Advancement of Science, and in the early part of his retiring address he spoke of the progress of science and wittily referred to certain attempts at progress as resembling the locomotion of a crab, sometimes sidewise, sometimes backward, or to that of the squid, which conceals its exact position by emitting clouds of ink.

In a previous chapter I referred to New Orleans and to the charming French restaurant kept by Victor Bérot on Bourbon Street. During the New Orleans meeting of the Association in I904 or 196.5, I naturally visited this restaurant as often as possible and introduced many members to it. So on New Year's Eve, when Professor Farlow invited me to sit out the Old Year with himself and his wife at some good restaurant, I naturally took them to Victor's old place. The restaurant was crowded, and at five minutes to midnight the head waiter came to our table and presented the compliments of the proprietor, with the hope that he might join us in drinking our healths on the stroke of mid- 


\section{FIGHTING THE INSECTS}

night. Old Victor was dead, but the new proprietor, with the same charming French courtesy that characterized his predecessor, came down the long room, stood with us as we rose, and with exquisite courtesy drank to our health and prosperity. It was quite as if it had been the ghost of old Victor himself. 


\section{Chapter XII}

I

Have no very good excuse for writing about the Presidents of the United States under whom I have served so long. During his office the President lives in the limelight, and the people throughout the country know much about him. But he is, for the term of his office, our first citizen, and therefore anything about him is of interest to all of us. Therefore, I shall set down what has happened to me in the way of contacts with presidents. With nearly all of them, these have been scanty, and it must be remembered that in all these years I was simply an insignificant office holder, and that there were in Washington very many others whose reminiscences of Presidents would be much more interesting than mine.

When I first went to Washington in November, I878, Rutherford B. Hayes was President-not a very popular President, but a very good one. He was a clean, straightforward, fine man, and Mrs. Hayes was one of the most beautiful and charming women I have ever met.

It so happened that Rutherford B. Hayes, Jr. (Rud Hayes, we called him) had been a fellow-student of mine at Cornell. In an earlier chapter I have told how Mac Borden and I used to go to the White House occasionally to play whist. Then we often saw 


\section{FIGHTING THE INSECTS}

both the President and Mrs. Hayes. The President seemed rather austere and was probably weighed down by official troubles, but Mrs. Hayes was friendly, democratic and motherly, and completely won the hearts of two rather lonesome boys. Her beauty and her charm are readily seen in the portrait of her painted by E. F. Andrews (my old and very dear friend) that still hangs in the White House.

The Presidential mansion was overrun with visitors in those days, and they were admitted to almost all parts of the building. They could even peep in the door (always open) of Mrs. Hayes' sitting-room, where she was often seen at her sewing-machine. As I remember it, her personal charm was like that of Mrs. Coolidge, so wonderfully well known to people of a much later date. Let me give you an example of the impression she made.

One day an excursion party arrived from Ithaca. They called upon their Member of Congress, Mr. Dwight, and asked him if he could get them a chance to shake hands with the President and Mrs. Hayes. Mr. Dwight arranged it readily, and they were asked to assemble at the White House at eleven o'clock one morning. Two of the excursionists, prominent Ithaca business men, old friends of mine, called on me at my office and asked me to go with them. The excursionists were a miscellaneous lot. We were ushered into the East Room, formed in line, and the President and Mrs. Hayes and Rud came in. Rud spotted me and called me off to one side, partly under a curtain, where we watched the show. The excursionists were greeted cordially as they passed the Presidential party, and they were greatly impressed. A few of the earlier ones came over and joined Rud and myself. Presently a man who had just passed through (I am ashamed to say that his shirt and collar were dirty and that his chin bore traces of tobacco juice) came up to us, beaming all over. 


\section{THE STORY OF AN ENTOMOLOGIST}

"Boys," he said to us, "what do you suppose she said to me? Would you believe it? She said, 'I am very glad to know you, Mr. Smith.' I am going back to Ithaca and tell my wife that the finest lady in the world said that she was very glad to know me!"

I knew Garfield before he was President. I have told of meeting him at President White's in Ithaca. He was then a Member of Congress from Ohio. When I came to Washington I saw him several times on the floor of the House and in the Congressional Library, but was too bashful to speak to him. Colonel and Mrs. Carter knew him very well, and he sometimes dropped into their apartment in the evening, with his friend, Charles Foster (at that time also a Member of Congress from Ohio and afterwards Secretary of the Treasury), and I was frequently called in for a hand at euchre. Later still, he lived at the corner of Thirteenth and I, next door to Nelly McCauley's boarding house, where I took my meals, and where the Garfields sometimes came for dinner. He was one of my great admirations, but I was too bashful to talk to him, although he was a .most approachable man.

Of course my most vivid recollection of President Garfield was when I saw Jules Guiteau shoot him in the old Pennsylvania Railroad Station as I was starting on my first Western field trip. But that I have told elsewhere.

I sarv very little of Presidents Arthur, Cleveland, Harrison, McKinley and Coolidge, and any statements of my impressions of these men would not add to the interest of this story.

Both from his political activities and from the fact that he was a keen naturalist, Roosevelt had always appealed to my imagination and interested me greatly. I had met him before his elec- 


\section{FIGHTING THE INSECTS}

tion to the Vice-Presidency. Recently the Roosevelt Distinguished Service Medal was presented to Dr. C. Hart Merriam, whom I have mentioned on an earlier page, and Merriam's address after receiving the medal is published in full in Science for February 12, I932. It is entitled "Roosevelt the Naturalist." In this address Dr. Merriam modestly referred to a meeting of the Biological Society of Washington, at which he had discussed the validity of several species of western animals, crossing swords with Roosevelt. That was when the future President was a member of the United States Civil Service Commission, somewhere between I889 and I895. I remember that meeting very well, since I was president of the Biological Society at the time.

One day the program committee of the society asked Dr. Merriam to present a paper at the next meeting. It seems that in the columns of the journal Science, Roosevelt had criticized Merriam's classification of the big game animals of North America, not so much from the standpoint of the systematic zoölogist, but from the standpoint of a hunter, claiming that Merriam went into too many refined details, and that lots of points known to the old trappers and hunters should be taken into consideration in basing a classification. Merriam told the committee that he would prepare a paper on big game animals if Mr. Roosevelt could be induced to be present at the meeting and discuss the paper. So it was arranged.

After the meeting had opened (it was in the old hall of the Cosmos Club) Mr. Roosevelt and W. Hallett Phillips came in at the back of the hall and sat on a rear seat. They were rather conspicuous because they were the only persons in the room in evening dress. They listened intently to Merriam's talk, in which, of course, he riddled Roosevelt's argument in Science. It was a long and very interesting address. At its conclusion, from the chair, I invited Mr. Roosevelt to take part in the discussion 


\section{THE STORY OF AN ENTOMOLOGIST}

although he was not a member of the society; whereupon he and Phillips came to the front, Phillips sitting in a front seat while Roosevelt took the floor. He made a very forceful argument from his viewpoint and obviously from that of other hunters, and rather staggered some of the scientific men in the audience by the cogency of his reasoning. He talked at length, as was customary with him, and the hour of adjournment (ten o'clock), came before he had finished. But by unanimous vote he was allowed to proceed until he was satisfied. He sat down after having made a distinct impression on his scientific and rather critical audience. Merriam asked for five minutes in which to reply. He completely demolished the Rooseveltian argument, and there was nothing more to be said. It was a memorable meeting, and no one who was there will ever forget it. Most of us saw Roosevelt for the first time and were greatly impressed by him.

Incidentally, the W. Hallett Phillips who was with him was a member of the Metropolitan Club and also of the Cosmos Club. He had evidently been dining with Roosevelt at the Metropolitan Club before attending the meeting. I knew him simply as a clubman and a society man and rather wondered why he was with Roosevelt and why he was interested in the subject. The meeting was on Saturday night, and on the following Monday I saw by the newspapers that Phillips had died on the intervening day. He had gone down the Potomac on a yacht, and the boat had jibbed, a halyard catching him around the neck, breaking it and throwing him into the water.

I knew nothing of Phillips' real life until some months later, when Rudyard Kipling published a poem, "The Red Gods," describing the tendency of the young man to get close to nature, to leave civilized pursuits, to get out into the woods and trackless wilds, etc. And this poem, to my surprise, was dedi- 


\section{FIGHTING THE INSECTS}

cated to Phillips. On inquiry I found that Phillips, after his seemingly butterfly life in Washington during the winter, went every year into the North Woods or some other far place and hunted and fished. Furthermore, he was interested in ethnology and had made a study of the American Indian. Of course this accounted for his acquaintance with Roosevelt.

When Roosevelt became President in September, Igor, he was forty-three years old, younger than I. Then for the first time I felt that I was growing old. At least two rather remarkable incidents during his administration stand out in my recollection.

The Panama Canal was about to be built, and the question of the health of the employees was a vital one. A committee consisting of Doctors Osler and Welch, of the Johns Hopkins Medical School; Dr. John R. Musser of Philadelphia, who was then President of the American Medical Association; Dr. Bryant of New York (then President of the New York Academy of Medicine); and I (representing the American Association for the Advancement of Science) called on the President to urge him to appoint a distinguished sanitarian as a member of the Panama Commission. Dr. Welch, in his usual happy and forceful way, began to state the argument, but was interrupted before he had said more than a sentence or two by the President, who, as I recall, spoke about as follows:

"Dr. Welch and gentlemen, I appreciate as fully and strongly as you can possibly put it the importance of sanitation in the digging of the Canal. I realize that the sanitary problem is quite as great as the engineering problem. If I could, I would follow your advice and would appoint a man who would meet with your approval, but I can not. My hands are tied. I remember that once, when I was hunting in the Dakotas-just my guide and myself-the weather was distinctly bad. The thermometer was an incredible number of degrees below zero; and the wind 


\section{THE STORY OF AN ENTOMOLOGIST}

was blowing an incredible number of miles per hour. Neither my guide nor I had said a word for a very long time, and then it began to snow. I opened my lips after this long silence and said, 'I'd rather it wouldn't snow.' The taciturn guide replied, 'This isn't a day for rathers.' Now, gentlemen, I would rather do as you suggest, but it isn't a day for rathers. The Congress has already fixed the composition of the Canal Commission. There must be an engineer, a business man, etc. Nothing is said about a sanitarian. But, assuring you of my deep appreciation of the matter, I promise you that I will find the best man possible, to take care of the health of the Zone. And I will see that he gets full authority, even if I have to pay him a salary larger than those of the Commissioners themselves."

Of course, history shows that he did not have to look beyond our own army, and that General Gorgas, fresh from his clean-up of Havana, was put in charge of the sanitation of the Canal with military authority.

During the Roosevelt administration the famous conference of the governors of the different States was held to discuss the subject of conservation. This was the first big conservation movement in the United States. In anticipation of the conference, experts in different departments of the governments were asked to prepare reports, which were assembled and studied. I happened to be one of the experts and was therefore invited to the conference. The sessions were held in the big East Room of the White House, and the scene was most impressive. President Roosevelt was in the chair. At one side of him sat the members of the Cabinet, and at the other Justices of the Supreme Court. The Reverend Edward Everett Hale, at that time approaching his end, gave the invocation. In the body of the room were seated, not only the governors of the different States of the Union and their aides, but prominent national figures of various 


\section{FIGHTING THE INSECTS}

kinds. William J. Bryan, for example, was there; John Mitchell, the leader of the Federation of Labor; J. J. Hill, the great railroad builder; Andrew Carnegie; the presidents of a number of principal universities, and all of the government experts.

At the conclusion of the morning session the President arose and said, "We have come together in this opening session before I have had the chance to greet you formally and to welcome you to the White House and to this conference. Therefore, I will take it as a favor if, as you pass out of the room, you will form in line and give me a chance to shake you by the hand and bid you welcome." This we did, and, as chance would have it, I found myself in line immediately behind Dr. C. Hart Merriam, the animal and bird man. Immediately in front of him was William J. Bryan. As we reached the President, Mr. Bryan, in a pompous and somewhat condescending way (at least it seemed so to me), said, "Mr. President, I congratulate you, sir, on having started this conservation movement, which, in my opinion, has tremendous possibilities of good for the future of our country. I assure you, sir, that it meets my entire approval and will receive my hearty support." The President, with a trace of a humorous gleam in his eye, as he looked over Mr. Bryan's shoulder and saw Merriam and myself, said simply, "Mr. Bryan, I am pleased. 'Praise from Sir Hubert is praise indeed." Then, turning instantly to Merriam, he said, "How are you, Hart? What do you suppose John" (meaning John Burroughs) "and I saw on the twenty-fifth of March at Pine Knot? A Yellow Warbler, by George!" And then, turning to me, said, "Hello, Doctor! How are the bugs?"

He was hail-fellow-well-met with all sorts of people, but could be quite the reverse, in fact, extremely dignified on occasion. I remember that once during his administration I went with the Pan-American Health Congress delegates to call at the [240] 


\section{THE STORY OF AN ENTOMOLOGIST}

White House. There was a long line of distinguished medical men from the Central and South American republics, and they were introduced to the President in turn by Dr. Walter Wyman, then Surgeon-General of the Public Health and Marine Hospital Service. The men in line could hear what the President said to each delegate as he was introduced. They were impressed not only by the solemnity of the occasion, but also by the extraordinary knowledge that the President showed concerning each individual presented, and by the happy manner in which he greeted him. For example, when Dr. Eduardo Liceaga, the President of the Superior Board of Health of Mexico, was introduced, the President said, "Dr. Liceaga, it affords me the most profound pleasure to greet you, sir, not only as the eminent sanitarian and administrator that you are, but as the representative of our nearest sister republic, for which we have the greatest admiration and affection." He said things like this to each man as he advanced, and the delegates were greatly impressed and formed in a group to listen. However, near the end of the line was Dr. A. H. Doty of New York, who had been Health Officer of that port when the President was Police Commissioner of New York City. As he reached the President, Dr. Wyman said, "Mr. President, it is not necessary to introduce this gentleman." Whereupon the President slapped Doty on the back and said, "Old man, how are you?" This was all right as far as Doty was concerned, but it altered the impression that the President had been making upon the Latin American delegates.

By the end of his administration, Roosevelt had made definite plans to start immediately on his African trip, and on the day before the inauguration of President Taft an invitation came to the bureau chiefs to call and say good-by. I went up late with Secretary James Wilson, Logan Waller Page and Allerton Cushman. I think that we were the last ones received. Secretary Wil- 


\section{FIGHTING THE INSECTS}

son introduced us, although it was not necessary, as the President knew us, and we said good-by. Roosevelt did practically all the talking, as was nearly always the case, but I managed to slip in a remark, quite by good luck, to this effect, "Mr. President, take especially good care of yourself in Africa, and by all means avoid the Sleeping Sickness." With his usual broad grin, he replied, "Good idea, Doctor! That disease wouldn't comport with the popular idea of my character, would it?"

On his return from Africa, he lectured before the National Geographic Society, and I met him at a luncheon given by Gilbert Grosvenor. There were no speeches at the luncheon, but he answered questions, and when I asked him about the Sleeping Sickness, he gave us an extraordinary account of the disease and of the ravages it had made in Africa.

Before he reached this country on his return from Africa, he travelled in Europe, lectured before the Sorbonne in Paris and also before the University of Berlin. As it happens, I was in Paris a month or so after he had been there. I have always been most cordially and hospitably received by my French friends, but it seemed to me that when I met Raphael Blanchard he was especially enthusiastic over my arrival. He at once invited me to luncheon and placed himself and his laboratories at my service. I wondered what I had done to arouse such an access of friendship. It came out in the course of conversation, when he said, "I met Colonel Roosevelt after his lecture at the Sorbonne at a reception given him by the Faculty. When I was introduced, I said to him, 'Colonel Roosevelt, I know Washington. I have visited that city and I know some scientific men over there.' He said, 'Do you indeed? Who?' 'Well,' I said, 'Dr. Howard and Dr. Stiles.' 'Oh,' said Colonel Roosevelt. 'Fine fellows, fine fellows." 'Thus Blanchard's enthusiasm on meeting me so soon after the Colonel had been there was explained. 


\section{THE STORY OF AN ENTOMOLOGIST}

It will be remembered that after this European visit, following his African trip, Colonel Roosevelt went to London as President Taft's personal representative at the funeral of King Edward (May 1910).

It must have been about 1913 that I was dining one night at Mr. Charles Francis Adams'. Mr. Henry White, ex-Ambassador to Italy, who greeted Colonel Roosevelt on his arrival from Africa and accompanied him on his European trip, was present. After dinner he told a number of anecdotes of the trip. They were all characteristic and extremely interesting, and I hope that in his reminiscences Mr. White will tell them to the world. One, however, I can not help jotting down here. It seems that after the funeral, the Colonel said to Mr. White, "Well, Henry, let us pack up and get ready to start home."

Mr. White replied, "We really must make some calls before we leave. For example, we should pay our farewell respects to the Kaiser" [who was then quartered temporarily in Buckingham Palace].

"Oh, thunder!" said the Colonel. "Of course. Come, let us get it over." So they went out, took an open barouche and drove to the palace. They found that the Kaiser was out, so they left their cards, reëntered the carriage, and were driving away when up came the Kaiser, also in an open carriage, with outriders. Seeing Colonel Roosevelt, the Kaiser leaned out and said in his excellent English, "Oh, Colonel Roosevelt, I am so glad I caught you. Turn around and come in, and we will have a good talk." Mr. White said that the Colonel deliberately pulled his watch from his pocket, glanced at it and said, "Your Majesty, I can give you just twenty minutes."

Gifford Pinchot was a warm personal friend of Colonel Roosevelt and saw him almost daily during his Presidency. In fact, the President publicly acknowledged that the birth of the con- 
servation idea was due to Pinchot, and that his own interest had been aroused by his friend's efforts. One day in the summer, meeting Pinchot and James Garfield (then Secretary of the Interior) over in the White Lot at a departmental ball game, Pinchot asked me to go home and dine with them informally. I did so. Secretary Wilson was at the table and so were two or three other men. The weather was hot, and everything was of the most informal character, although the dinner was excellent and the service what one would expect in such a well-appointed house. Toward the end of the dinner Pinchot said, "I must tell you what happened yesterday. Robert Bacon has just been appointed Assistant Secretary of State and made his first formal call on the President yesterday afternoon. The President looked him over and asked him if he would like to take a walk. $\mathrm{He}$ said that he would. And then the President telephoned me to come over to the White House for a tramp. I knew what that meant. I opened the door of a closet in my office and put on a suit of old clothes that I always keep there, then started post haste for the White House. When Bacon saw me he said, 'Why, Mr. President, I am not dressed for such a tramp as Pinchot and you are going on.' But the President said, 'Never mind, come along.' And Bacon, like the good sport he proved to be, came along. We went down south of the White House until we got into some waste land covered with high weeds and found ourselves on the bank of an old canal. We looked around for a boat, but there was none, and the President said, 'Come on, let's swim across.' Bacon took his watch and his pocket book out and put them in his tall hat and plunged in with the President and myself. On the other side, the President said, 'Come on, let's walk fast, boys, and get dry.' And so we tramped over through Georgetown, up over the hills into the Rock Creek valley, the President choosing a trail which he knew, and which is as stiff 


\section{THE STORY OF AN ENTOMOLOGIST}

a one as could be found. We kept it up till we arrived somewhere out near the 7 th Street road. There we found horses waiting for us, and we rode back into the city. You can imagine the condition of our clothes and how we looked. I reached home toward dark and as I came in the front door my old Irish nurse met me. She held up her hands and said, 'Oh, Mr. Gifford, you've been with the President again!" Pinchot urged us not to tell this story, but now it can be told. The President was evidently trying Bacon out, knowing that he was a man of wealth and could readily stand the damage to his clothes. It was not the kind of test that would appeal to most people, but it was Roosevelt all over.

At one time during his administration some one gave him or the White House a beautiful grand piano. It had not been installed very long before the Roosevelts gave one of their charming musicales. Mrs. Howard had a superb voice-a dramatic soprano-and she was invited to be the soloist at this musicale. I was invited to attend, but I had to leave that night for St. Louis, where I was to give a lecture before the Twentieth Century Club. I got ready to go to my train and stopped at the Cosmos Club on the way to the station. Then it occurred to me that I had time to listen to at least one song if I could arrange it. So I left my bag at the Club and walked down to the east end of the White House. There were numerous police. I walked up to one who looked authoritative and at the same time good-natured, and asked him if I could slip into the grounds and stand under the window of the East Room to listen to my wife sing. He didn't scratch his head, but looked as if he wanted to.

"I'm afraid it would not be allowed, sir," he said. "But why don't you go in? You say that you were invited, and I am sure that they would let you in." 


\section{FIGHTING THE INSECTS}

"But," I said, "I am not dressed. I am taking a train in an hour. It would be very simple for me to creep up to the window and listen."

"I understand your feelings perfectly, sir. I sympathize with you deeply. I'd feel just the same way if my wife were singing. But you see I have strict orders. I'll tell you what to do. The Captain is somewhere down there" (pointing indefinitely to the south). "Hunt him up and put the case to him." The Captain was too far away, and of course would never have given me permission. But the incident shows the extraordinary tact and sympathy of at least one of the President's guard.

We all had very pleasant expectations when William $\mathrm{H}$. Taft was elected President. He and Roosevelt had been warm friends, and we quite expected that Roosevelt's policies would be followed. But President Taft, while a most admirable person, and greatly liked by those who knew him best, had a different sort of mind. He was a big, broad, genial man, but his was a legal mind. I had hailed his election on account of his high standing, and, incidentally, felt a bit of family pride, since it was the first time in the history of the republic that a man of Howard blood had reached this high office. I had met him and chatted with him at Mr. Gardiner Hubbard's before he went out to the Philippines as Governor-General, and I liked him enormously.

Shortly after his inauguration, I went to Europe, and on my return to Washington, in late August, I was invited to a dinner at the Chevy Chase Club in honor of Mr. Wickersham, who had just been appointed Attorney-General. The hostess was Mrs. John D. Patten, a girlhood friend of Mrs. Wickersham. Almost every one was out of town at that time of the year, and Mrs. Patten was the only lady at the table. Mr. Wickersham sat at her right, and I on his right. I chatted with Mr. Wickersham

$$
\text { [246] }
$$




\section{THE STORY OF AN ENTOMOLOGIST}

while Mrs. Patten was engaged on the other side, and we had a very interesting discussion of Provençal poetry, a subject that is a great hobby of his. He was greatly interested to know that I had met Mistral, but the chat was necessarily very short. Before he turned from me, he said, "How do you find things on your return to Washington?"

"Oh," I said, "I am greatly distressed. My dear friend Pinchot has resigned, and my dear friends North and Newell are under fire."

"Are they such dear friends of yours?" said he. "Well, you might as well understand, Dr. Howard, that this administration is going to be a strictly legal administration." That seems to have been at the bottom of the trouble that ensued, and certain following events swerved my sympathy from the Taft administration, although I still admired the President very warmly.

I think that it was during the Roosevelt administration that I began receiving invitations to the White House functions, and this continued until I left Washington in 193r. I mention this here since I shall always remember the great pleasure it was to go to the White House while Taft was there. He was such a good fellow, so jolly, so cordial, that it made one feel good for a week to see him and shake his hand.

In I9II-I2 the American Association for the Advancement of Science met in Washington. The opening session was held in the large hall of the National Museum. President Taft had consented to give an address of welcome. Dr. Charles E. Bessey, a famous botanist, and at that time president of the University of Nebraska, was president of the Association. Dr. Bessey and I met the President at the north door of the museum. He was accompanied by Colonel Archie Butt, his military aide, and by other attendants, whom he dismissed. The four of us took places on the stage, the audience of course rising as we entered. A dozen 


\section{FIGHTING THE INSECTS}

or more ex-presidents of the Association were also seated on the stage. Colonel Butt was seated in the second row immediately behind President Taft, and I sat next to Colonel Butt. In his address of welcome the President was very happy, but I am telling this story on account of one little incident. He said substantially, among many other pleasant and pertinent things, "I am sure that the scientific men of Washington are very glad to have you here, and I feel that this meeting is a great honor to Washington. Moreover, I am sure that you are glad to come here. Not only is it the Capitol of the nation, of which every citizen should be proud, but it is a center of the greatest scientific interest. You will be glad to see for yourselves the inner workings of our great scientific bureaus, such as the Coast and Geodetic Survey, the Smithsonian Institution, the Geological Survey, the U. S. Naval Observatory, and- " Here he hesitated. His memory had failed him for the moment. Obviously he couldn't think of any more big scientific bureaus. At that time the Bureau of Entomology was small, but I was its chief and had its interests very much at heart. I said to myself, "Oh, if the Bureau of Entomology were only important enough to be mentioned right here!" Evidently there was a thought transference, for the President resumed, "And the Bureau of Entomology." And Archie Butt kicked me maliciously on the shins.

Years afterwards I had a chat one night in New Haven with the ex-President, and I told him this story. It brought out his famous chuckle, which, however, had lost some of its irresistible quality after the President had lost sixty or seventy pounds by diet and exercise.

I first met Woodrow Wilson in the early part of the century at a supper in Brooklyn. Professor Wilson, Professor Jeremiah W. Jenks of Cornell, and I had lectured the same evening in 


\section{THE STORY OF AN ENTOMOLOGIST}

different halls before the Brooklyn Institute of Arts and Sciences. The Hamilton Club of Brooklyn invited all three of us to a big supper following the lectures. But one speech was made, and that was by Mr. Wilson. I remember his opening very vividly. $\mathrm{He}$ announced that he understood very well that the members of the Club were mainly men of large affairs, engaged in the financial whirlpool across the river. He supposed, therefore, that they must think it strange that he, from the little town of Princeton, and Jenks, from the little town of Ithaca, should have the audacity to come to Brooklyn to tell them something about financial things.

"But," he said, "you are down striving in the middle of affairs, while Jenks and I are in the position of men up in a balloon. We see the perspective that you can not see."

For the same reason that I have omitted comment on four of the Presidents under whom I have served, I shall insert nothing more about Mr. Wilson. I met him occasionally, once upon the golf links, and I am sure that his devotion to this game helped to keep him fit during the long and anxious years when he occupied the Presidential chair.

Of course I shared the general public opinion on the election of President Harding, and my personal views concerning him were very much like those of most people. He was a handsome, impressive and very charming man. When I first shook hands with him at a White House reception he gave me the feeling that I was a man whom he was especially glad to know, and I feel sure that he gave the same impression to all. I rejoiced with every one else over the big international conference for the reduction of the navies of the world, and looked upon the newly established Bureau of the Budget with interest but also with watchful waiting. When, however, the President called 


\section{FIGHTING THE INSECTS}

the first meeting of the bureau chiefs of the government, I was enormously impressed. There on the platform were the President and his Cabinet, and General Dawes, the first director of the Budget. But the audience was composed of some six hundred of the men who had charge of the details of administration of our great country. I realized then as never before that Presidents and Cabinets come and go, but that these six hundred men go on year after year and that the successful administration of the country is largely in their hands. President Harding made the opening speech. He was not a very impressive speaker. His voice was monotonous, and his choice of words was far from scholastic. His gestures were rather awkward, but his benevolent face and fine presence carried it all off.

One more little personal incident. In the thousands of pages that have been printed about President Harding it has always been said that not only was he a small-town man, but that, like the small-town man, he was promiscuous in his friendships. $\mathrm{He}$ had not only a genius for friendships, but an obvious desire to be friends with every one. One day, a little after half-past four, I was at the Cosmos Club, having just gone there from my office, when I was called to the telephone. After I had said, "Hello," a voice replied, "Is that Dr. Howard? The President wishes to speak to you." I said to myself, "The President of what?" when Mr. Harding's fine voice said, "Good afternoon, Dr. Howard. A friend of mine from Atlanta, Georgia, has just told me that you refused to investigate an admirable remedy for the Cotton Boll Weevil that he is just beginning to exploit in a business way. Now I don't think you ought to refuse a request of this kind."

"Why, Mr. President," I answered, "I have done nothing of the sort. I shall be glad to have it investigated at the first opportunity. But I can't endorse it without investigation, and as it is 


\section{THE STORY OF AN ENTOMOLOGIST}

now November, the cotton has all been picked and the weevils have gone into hibernation."

"Well," said the President, "isn't there something that you can do about it? The man is a friend of mine, and he is a fine fellow."

"Is he there with you, sir?"

He replied that he was, and I asked him to send the man over to see me at the Club.

The man, a very pleasant fellow, came over and we had a talk. I told him politely that if he would send his compound to our laboratory at Tallulah, Louisiana, it would be tested the following summer. It seemed to me that this was obviously a case-and we encountered many of them in our work-in which, after the growing season, secret compounds were rushed on the market and were sold by the carloads before the coming season should give a chance for a test. And so it turned out. The remedy was a practical failure, and I believe that the man who called on me got into financial difficulties and committed suicide the next year.

But wasn't it an excellent example of President Harding's small-town friendliness? It was the only time in fifty-four years of government service that a President of the United States called me personally on the telephone.

There is one final anecdote that I must tell, since it throws an interesting sidelight. The Secretary of Agriculture during the Harding administration was Henry C. Wallace of Iowa. The bureau chiefs of the Department arranged a luncheon in his honor on his birthday. It was held in one of the big private dining-rooms at the Cosmos Club. Thirty or forty of us gathered at the appointed hour, and were standing at our places when the Secretary, a little late, arrived. I was to preside at the luncheon, and was standing at the end of the table next to the late Professor Whitney. The Secretary came to his place between 


\section{FIGHTING THE INSECTS}

Whitney and myself, put his arms around our shoulders, and said in a low voice, "I have been delayed at a Cabinet meeting, and as it broke up that fine President of ours took me by the arm and said, 'Henry, I hear that it's your birthday. Come in here.' And he took me into the next room, opened a cupboard and gave me a drink of the best whiskey I have ever tasted." So much for Prohibition!

It is probably not strange that I have never met President Hoover personally. He joined the Cosmos Club when he was Secretary of Commerce, but I have never seen him there. I think that his friends must have been asked not to introduce him to people, and I judge that he is naturally a very reserved and perhaps, even shy man. I know, however, that he is a lover of nature, and that when he wishes to do so, he can write with very great charm and with a pronounced sense of humor. One of the most beautiful addresses I ever listened to was read by him at a big dinner at one of the Washington hotels during a convention of the many societies of lovers of nature. It was on the delights of fishing. 


\section{Chapter XIII}

\section{L}

ors of people know that there is an extraordinary institution in Washington known as the Cosmos Club. At the present time it has become well known among a certain class. Nowadays, there are perhaps three other clubs in the United States that can be mentioned in the same breath, namely, the Saint Botolph of Boston, the Century Association of New York, and the Bohemian Club of San Francisco. In Europe I know of only one old club of similar standing, and that is the Athenxum. But, famous as it is, the Athenæum entirely lacks the charming atmosphere of the American clubs. It is frigid. A high standing in accomplishment in all lines of intellectual endeavor is required by the Athenæum, and some of the best names in Great Britain have been associated with it. The Saint Botolph in Boston has somewhat similar standards, and many of the finest men in New England have belonged to it. The same may be said of the Century Association in New York. Artists, writers and men of science are found there. The Bohemian Club is more catholic. It admits actors and musicians (the Saint Botolph Club also admits certain of the best of the Boston Symphony Orchestra), and also certain professional and business men of culture, and, 


\section{FIGHTING THE INSECTS}

possibly on account of the element of theatrical people, its "High Jinks" have become famous in America.

The Cosmos Club, however, seems to be a bit more restricted and at the same time somewhat broader than the other three American clubs. It primarily consists of men who have done meritorious work in literature, the arts and in science, but it also includes men who are distinguished in any one of the learned professions or in the government service. Moreover, it admits certain men who, although not professionally engaged in literature, the arts or in science, are known to be highly cultivated amateurs.

The Cosmos now occupies the old Dolly Madison house in Washington, and several adjoining houses have been added to it. It began in a small way about 1879 , and has grown in size, in reputation, and in facilities. At this time it has perhaps eighteen hundred members, about half of them non-resident.

When I married in I886, my wife, with extraordinary foresight, told me that I must join this Club, and I did so at her command. I have never regretted it. The charges were very reasonable in those days. The entrance fee was only $\$ 50$, and the annual dues were $\$ 35$, so that it was quite possible for poor scientific men to join if they could secure election. The late Mark W. Harrington, at one time Chief of the United States Weather Bureau, told me once that one of his assistants had said to him, "I have been urged to join the Cosmos Club, but I can't afford it."

Professor Harrington said to him, "My dear man, you cannot afford not to."

And he was quite right. The Club has done wonders for many a young man who, having achieved some scientific prominence, must work for an extremely modest government salary. During the forty-five or forty-six years since I joined this [254] 


\section{THE STORY OF AN ENTOMOLOGIST}

extraordinary Club it has become my second home. Not only has an endless procession of distinguished men, both Americans and foreigners, passed through its doors, but the membership itself has been not only a constant source of delight, but of the most enormous educational value. The talk there is not always brilliant, not always stimulating, but on the whole it is worth more than any talk I have ever heard elsewhere. If a man sits there chatting with a friend and some divided opinion shows up, it has been our custom to look around the rooms a bit, and it rarely happens that we do not find in some corner a world authority on the subject, reading a newspaper or writing a letter or chatting with some colleague.

What a chance for a young man who is unpolished in the ways of the world and rather narrowly trained, but who has done enough sound scientific work to fit him for entrance into the Club, to broaden out and get new ideas, and even to learn from older men how to look at his own work in a bigger way! I have seen many a raw young man develop visibly from month to month, even in matters of dress and personal habits. It must be confessed, however, that the individuality of many men is so strong that they remain unaffected, except, perhaps, in a small way. Some of them seem even more interesting from this fact. But the foreigners! There have been so many of them! Alexander Helmholz was there once, and other great men have made the Club their headquarters when in Washington. I have talked there with Joseph Chamberlain, with Henry Irving, with Lord Kelvin. James Bryce, when British Ambassador to Washington, came frequently to the Club. Jules Jusserand, when French Ambassador, belonged to the Club for many years, although he seldom visited it. A number of times I have met him at receptions and have said, "Excellency, why don't you come to the Club oftener?" and he invariably replied, "My dear 


\section{FIGHTING THE INSECTS}

Docteur, you see, I am so happily married." It is a pleasure to remember that Madame Jusserand is an American.

I was secretary of the Club for many years. In fact, I have held every office except that of treasurer. But I don't consider that my non-election to that office is any reflection on my honesty.

I remember once when we were giving a reception to Lord Kelvin, and I, as secretary, was introducing the men as they approached the receiving line, General Joe Hawley came up. At that time he was a United States Senator from Connecticut. On being introduced, he said, "Lord Kelvin, you are a Scotsman and a great physicist. You probably knew another Scotsman who was also a physicist. I met him in 1876 . His name was Sir William Thomson."

"Yes," said Lord Kelvin, "I imagine that no one knows him better than I do."

"I hope he is quite well," said Senator Hawley.

"He is quite well," said Lord Kelvin. "In fact, he is in the same condition of robust health as I am myself." It had evidently not occurred to the Senator that Lord Kelvin was once Sir William Thomson.

The Club has always been marked by a sort of dignified simplicity, but the atmosphere has been of the friendliest kind. Men speak to each other there without introduction, and one is sure to find every other man interesting. Some of the cleverest things I ever heard have been said there in ordinary conversation. In fact, it is said in Washington that if one wishes to dine well, he should go to the Metropolitan Club, but that after dinner he should always adjourn to the Cosmos Club for conversation.

In the old days before Prohibition the Club was rather noted for its safe liquors. In fact, the so-called "Wiley Scotch" was widely known. It was named after Dr. Harvey W. Wiley, the 


\section{THE STORY OF AN ENTOMOLOGIST}

great chemist and author of the Pure Food Law, who for a long time was chairman of the House Committee. Dr. Wiley was not only of great service to the Club in that capacity, but he was a constant joy to all of us. I think that he was the wittiest man I have ever known. At one period we were often invited to speak at the same dinners, but before long I made up my mind that it was desirable for me to speak after Wiley and not before. The climax was reached at a dinner in New York, at which I preceded him. Nearly all the speakers were from Washington, and I pointed out this fact, and, since they were all probably strangers to the diners, I told something about each one. As to Wiley, I repeated one or two stories. When he got up, after a few words, he said, "As to my friend Howard, I advise him to stop his study of the Cotton Boll Weevil and the San José Scale and the malarial mosquito, and to turn his attention encirely to the Chestnut Blight." Whereupon the audience roared at my expense so vociferously that never afterwards did I speak before him.

Every old member of the Club must have a host of recollections of unusual and interesting people, and of unusual and interesting conversations. One night in the billiard room I saw a well-known zoölogist and an equally well-known writer playing billiards. The author was a large, heavy man, and he played in a very deliberate way. I listened to the following conversation between them:

Zoölogist: It is surprising to me that so fine a man should be so lazy.

Author: Do you know that I attribute my splendid physical condition at this advanced age entirely to indolence? Lazy people and the lazy animals always command my admiration and respect. Take the alligator, for example. There is an ideal animal. He lies on his belly and basks in the sun for hours upon hours. When the necessity or 


\section{FIGHTING THE INSECTS}

opportunity to feed comes, he goes at it in a momentary fit of energy, swallows a fugitive negro baby, and then lies and digests and basks in the sunlight while the barnacles gather undisturbed on his back.

Zoölogist: Your combination of alligators and barnacles is an unfortunate one. Alligators live in fresh water, and barnacles in salt water.

Author: You don't seem to be very familiar with the science of geography. In the State of Chiapas in Mexico there is a place where the salt water and the fresh water mingle, and where the alligators have acquired a taste for brackish water, and the barnacles have acquired a thirst for semi-freshwater, and they cohabit, the one upon the other, in the most perfect harmony.

Zoollogist: If you had told that to another man, he might have believed it, but I was born in the State of Chiapas.

Author: Then, under the new constitution of the Republic of Mexico, adopted last month, you are a citizen of that country. What are you doing, holding public office in the United States?

Zoölogist: I would be out of place if my statement of having been born in the State of Chiapas were not exactly the same kind of statement as yours about the alligators and the barnacles.

Author: Nevertheless, I have a deep fellow sympathy for both the alligator and the crocodile.

A bystander: After all, what is the real difference between an alligator and a crocodile?

Author: I'm not very familiar with the real structural differences, but they have many points of resemblance. Both have low retreating foreheads, and, consequently, a rather inferior mentality. But each has a different opsonic index.

Zoölogist: How essential a vocabulary is to a popular writer!

Author: Yes, Doctor, that's all he needs!

Artists are not so numerous in the Club as are scientific men. I shall speak of Frank Millet, but there have been a number of others, some of them of quite his rank, and still others of very considerable reputations. On September 20, I925, I made a note of the fact that one of the greatest living American sculptors, Paul Wayland Bartlett, had just died in Paris. I hap- 


\section{THE STORY OF AN ENTOMOLOGIST}

pened to know him slightly at the Club. I like Bartlett's work immensely, but my opinion of that doesn't count. I liked him greatly as a man, however, and that does count. Probably my liking for him is largely due to what he said when Glenn Brown, the architect, introduced me to him at the Club. Brown said in his deliberate way, "Mr. Bartlett, I want to introduce you to Dr. Howard, who has probably done as much in his way as you have in yours."

"Oh," said I, protesting, "Mr. Bartlett has done such big things, and I am working with such little things."

"But," said Mr. Bartlett, with his charming and clever French courtesy, "you do it in such a big way, Dr. Howard!"

In 1915 Bartlett exhibited at the San Francisco Exhibition a superb equestrian statue of Lafayette, with sword held aloft. He presented a small replica (about three and a half feet tall) to the Cosmos Club, and it was placed in the Reading Room. One day a member was showing a visitor around the Club, and they stopped in the doorway of this room. Dr. Henry S. Washington, a man of striking and distinguished appearance, was standing at a reading table, looking over the journals. Looking at the statue, the visitor said, "Is that Washington?" The member, looking at Washington, said, "Yes." The visitor, walking over to the statue and looking at the label, replied very politely, "You're a liar. It's Lafayette." The humor of this incident is difficult to analyze, but it is distinctly there-to an American, at least.

I can't leave the subject of the Cosmos Club without referring again to Harvey W. Wiley. He was a great human being. I saw him in many places, at the Department, at scientific meetings, at dinners and receptions, but most often at the Club. In fact, he was one of my original sponsors there back in the spring 


\section{FIGHTING THE INSECTS}

of 1886 . He will always be remembered for his great scientific work, and more particularly for his successful labors in the cause of Pure Food and Drugs, since he took up that idea at an early date and labored manfully until he had achieved success. In fact, one of my cherished recollections is a journey to Europe on the old St. Louis in 1902, when we sat side by side, day after day, and he talked to me at length about his plans for his famous so-called "Borax Squad," by the aid of which he hoped to show the exact function of borax as a preservative in canned food and its effect upon the human system.

But it was as a highly original and very delightful humorist that Wiley will live longest in the minds of many. I have the impression that I knew him for ten years before I ever heard him talk seriously. He was one continuous sparkle of humor, and the good things that he said will be quoted for years to come. It was not a malicious humor. As I remember it, none of the funny things he said ever hurt anyone. And he occasionally wrote very comical poetry, some of which has been published. I am sorry that I cannot place my hands on some of his best, but there is one amusing little thing that comes to my mind.

Back in 1922, C. A. Jacobson, of the University of West Virginia, organized with the assistance of the chemical faculty of the university a spelling match among the several hundred students taking the course in General Inorganic Chemistry. It was a public match for the spelling of chemical formulx of such compounds as are ordinarily included in a first-year college course in chemistry. This match was described by Professor Jacobson in the journal Science for September 29, 1922. I read the article with interest, and sent Dr. Cattell the following note, which was published in Science for October 20 of that year: "Hurrah for Professor Jacobson and his chemical spelling [260] 


\section{THE STORY OF AN ENTOMOLOGIST}

match at the West Virginia University as described in Science for September 29! 'Twenty-odd years' experience when permanent secretary for the American Association for the Advancement of Science, in reading the proofs of the programs of the chemical section, gave me some definite opinions of chemical terms. I was delighted in reading the preface to a book recently published by the veteran naturalist Auguste Forel to note the expression: "la vraie science est l'ennemi des grand mots." Is it a plain inference from Forel's dictum that chemistry is not a true science?"

In Science of the next week appeared the following jingle signed by Wiley:

\section{Howard on Chemical Spelling}

Oh, Leland, tell me, tell me true-

The explanation's up to you-

Why did you break the portals down

And jump into the Chemists' Town?

But wait a minute; now I see

To solve the riddle's up to me.

You still are in your own domain,

Where you without a rival reign,

For, as the fact appears to me,

You're trying to catch that spelling-bee.

I am sorry to record that these two bits of nonsense called forth a rather serious protest received by the editor of Science, which he sent to me for my opinion, remarking in his letter, "You see what happens to the editor of an otherwise respectable scientific journal if he once admits to its columns a bit of chaff."

During the time of the Great War, the Club was extremely interesting. The government had brought together in Washing- 


\section{FIGHTING THE INSECTS}

ton a large number of specialists from the university laboratories. Naturally, they were put up at the Cosmos, and many of them lived there. They were all in uniform. There were not only many physicists and chemists, but there were also economists, lawyers and medical men from all over the United States. And there were astronomers and mathematicians, too. I never knew exactly what the latter did, but they were useful. The others did all sorts of valuable things. Many of them were so anxious to help that they were willing do do anything. I remember that the eminent Dr. William $\mathrm{H}$. Welch, of Johns Hopkins, disappeared from Baltimore (he was and is an old bachelor), and his friends got worried about him. It came about that for days he had occupied a desk outside the office door of the Surgeon-General of the Army, and was concerned simply in slitting open letters, until an office suitable to his extraordinary ability was found.

As an indication of how widely the university laboratories were represented, I was sitting in the window one day when a college professor from Chicago approached and said, "Howard, you know a lot about the details of management of different universities in this country. Can you tell me what the practice is (in such and such a situation) in, say, Harvard and the University of California?"

I answered that I could not tell him, but pointed out across the room two men at the mailbox, looking for letters, and said, "There are a Harvard professor and a California professor standing side by side. Go and ask them."

And not only was the Club crowded with men of this type. The uniforms of the liaison officers of many of the allied nations were seen there daily. The great dining-room on the fifth floor was crowded, especially at luncheon. I have seen all of the [262] 


\section{THE STORY OF AN ENTOMOLOGIST}

members of President Wilson's cabinet (they were nearly all Club members) waiting for a chance for a seat.

Along in October, 1917, we began to notice the increasing number of uniforms of the officers of the allied armies. They had been sent over from England, France and Italy. They were nearly all experts in some special line, and had been sent to the United States to assist us in our manifold preparations. Not only were these men selected by their governments for their skilled knowledge in branches of science whose applications to war purposes had been discovered and enormously developed during the previous year or two, but they were chosen also, apparently, for their attractive personalities, and, very naturally, for their command of the English language. The latter point had been especially forced upon us the summer before. One night I was sitting in the reading room of the Club, and some man from the State Department came in and said, "Oh, Doctor, you're just the man I want to see. You speak French. Come and meet some of the French scientific men who have just arrived." I went into the big reception room and found six finelooking Frenchmen in the beautiful French uniform, and was introduced. Among them were Professor Henri Abram, of Paris; Professor Fabbri, of Marseilles; the Duc de Guiche, a famous amateur physicist of Paris; and three others whose names I have forgotten. Dr. Henry S. Washington and I kept up a somewhat laborious conversation with these men in the French language until, at the expiration of an hour or two, it gradually dawned on us that they all spoke English much better than we did French.

Along in October I happened to be talking at luncheon at the National Museum with Austin H. Clark, a Harvard graduate, and a well-known oceanographer, who had travelled all over the world. At that time he was possibly thirty-five years 


\section{FIGHTING THE INSECTS}

of age. We spoke of the charming Italian and English officers whom he had met recently (he speaks Italian and Russian). I told him that I had met a number of these men in little groups at the Club, and together we hatched out a plan to bring them all together at an informal reception with the ambassadors of the different allied countries. Invitations were sent out at our suggestion by the Board of Management of the Club on the 2gth of October (the last of the wet Monday nights in Washington under the provisions of the then new Prohibition Act, which went into effect November Ist). The different allied ambassadors had been invited to bring with them their Embassy staffs, and all of the expert officers and members of commissions in town.

The reception was largely attended. Perhaps two hundred members of the Club were there, and possibly a hundred of the Allies, together with other guests holding cards. The officers wore their medals and decorations, and it was as brilliant a reception as I have beheld since the Court reception in Vienna in 1907. But only one of the ambassadors was there, and that was Sato of Japan. Spring-Rice, of Great Britain, had gone to Canada to attend a wedding, the Italian ambassador was sick, and Jusserand had another pressing engagement. But a number of the attachés were present, and there were many military men, representing Italy, France, Russia, and England.

It had been a question of some doubt in my mind as to whether any of the German-American members of the Club would turn up. As a matter of fact, I saw only one of them there, Professor Schmidt, of the Congressional Library, a very pleasant man, and probably a pro-Ally. I don't know.

The house committee had provided a very good buffet supper, with plenty of strong rum punch, and, after a little initial stiffness, things warmed up, and the crowd stayed in animated talk 


\section{THE STORY OF AN ENTOMOLOGIST}

until midnight. I introduced myself to Colonel Mizukuchi of the Japanese Army, who knew a lot of my Japanese friends, and who in turn introduced me to Captain Nomoura of the Japanese Navy, and also to Baron Sato. I met, as well, the Russian Lieutenant-General Vladimir Roop; the Italian General Guglielmotti and the other Italian officers, General Tazzi, Captain Count Enrico Luserna di Campigniole, and Baron Balentini. The Frenchmen I met were Colonel Martin, Captain Rostand, Lieutenant Paternot and Lieutenant l'Englais. I also met a number of the English officers. Lord Eustace Percy had been a member of the Club for some years and had been an attaché of the Embassy before the outbreak of the war. The other English officers were General McLacklan, General McCormick, Colonel Goodwin, Major Row, Captain Kingman and Captain Dudley. I was especially impressed by General Guglielmotti. He was then a man of fifty-one, with a complexion like a boy of eighteen, and was full of vivacious interest and good nature. I introduced to him Lieutenant Crenshaw of the U. S. Reserve. Crenshaw was a chemist who formerly worked in the geophysical laboratory and had been badly poisoned with chlorine gas the year before. He had recovered, had been given a commission, and put at work on poisonous gases-obviously a very appropriate appointment. General Guglielmotti was much interested in him, examined his uniform and remarked on leaving him, "I go away tomorrow. When I see you again I predict you will be at least a colonel, probably a general." I talked with the general for some time, and he never failed to say the kind, tactful, interesting thing. The Frenchman Paternot had been in prison in Germany and had had a devil of a time. He showed it in his face. Another Frenchman, l'Englais, a young chap with one of the sweetest faces I ever saw, had lost his kneecap from a shrapnel wound received on the Aisne. 


\section{FIGHTING THE INSECTS}

The whole reception was beautiful and inspiring, and it helped, undoubtedly, to bring about a feeling of friendship and brotherhood that should have spread out even more than it did among the allied nations.

The memories of those of us who lived through the war period will be crowded forever with interesting incidents. That is true even with those of us who did not go to the Front, and it is, perhaps, especially true of those of us who lived in Washington, where the high direction of the United States activities centered. And it was the special function of the Cosmos Club to be the host of many quiet but important actors in the drama. In November, 1917, there came to see me at the Club, Dr. A. Caccini, a highly educated Italian physician, who had been connected in the early part of the century with Celli, Casagrandi, Grassi and that group in the mosquito-malarial work at Rome. $\mathrm{He}$ was a classmate, by the way, of Tiraboschi. He had come to this country in 1904 and had begun corresponding with me in 1906. He had located in New York and had practised there for a number of years. He put me in correspondence with the Italian school at Rome and gave me very effective letters to Celli, Grassi and the others when I went over in the spring of I9ı. He was a broad biologist and, I think, a naturalized citizen. At all events, he was a very patriotic American. At the time of the outbreak of Asiatic cholera in Italy (in IgII, I believe), he came down to Washington, and I went with him to the office of the Surgeon-General of the Public Health Service to introduce him to Dr. Walter Wyman. He offered his services as quarantine officer at the Italian ports. His high scientific and medical standing, and his familiarity with Italian and other foreign languages, fitted him admirably for this work. The interview was pleasant enough, but his offer was turned down 


\section{THE STORY OF AN ENTOMOLOGIST}

rather unceremoniously and an American officer of the Public Health Service was kept in charge.

It seems that when we declared war against Germany, Dr. Caccini offered his services to the Medical Reserve, was appointed a Major, and was placed in charge of the medical work at the great aviation training-school at Fort Worth, Texas. He was then on his way from the aviation training-camp at Mineola. I introduced him to a lot of men, and he told us many interesting stories. While at Forth Worth he used the airplane to visit his different stations, and, speaking many languages, and being a social sort of man, he talked with all kinds of people. Once when he was conversing in German with a restaurant keeper he was accused of being a German spy in American uniform. He was promptly exonerated through his personal acquaintance with the District Judge. When he told this story at the Club an American member said, "That is interesting, but not half so exciting as something that occurred here at the Club. A man put his head into the reading room and remarked, 'See that German professor?' The alleged German professor, who was an extremely patriotic American, picked up his chair, hit the man over the head and killed him instantly. He was carried to the police station, where he got into consultation over the telephone with the Chief of Police, the Attorney General of the United States and the Chief Justice of the Supreme Court, who all agreed that the homicide was so justifiable that the man was liberated before bedtime."

This story was told seriously, and it was amusing to see the puzzled expression on Caccini's face, and also on that of Captain Luserna de Castiglione of the Italian Commission. They were not accustomed to the exaggerated American sense of humor.

Then we all went into the library and examined the Italian war maps given to the Club by General Guglielmotti, and 


\section{FIGHTING THE INSECTS}

Caccini explained the campaign then going on in North Italy. $\mathrm{He}$ predicted that the Italians, if speedily supplied with ammunition and cannon, would drive the Austrians back to the mountains about the first quarter of the winter and would annihilate them in the mountain passes. He said that it would be an experience similar to the retreat of Napoleon I from Moscow. Afterwards, we stood for an hour and a half listening to a discussion between the Italians on social conditions in Italy as compared with those in America, with especial reference to the army composition and support. The interesting point was pushed that the Italians did not need men, since they had eight million, but only munitions, guns and supplies. They said that more men from the allies would be embarrassing, since it takes twice as much food to support a soldier of any other nation as it does an Italian. Then, too, every Italian can cook. A lot of other points were brought out, which I did not quite get, as I understood only about every third word of their rapid Italian speech. Another irteresting man I met at the Club during this general period was Dr. L. P. DeBussy, the charming Hollander of whom I have written elsewhere. He had travelled extensively with me in the States in 1910, and had then gone back to Sumatra. In May, I9I7, he had received an appointment as director of the Zoölogical section of the Colonial Museum in Amsterdam. He had started from Sumatra in late August, arrived in San Francisco about the first of October, and found there that if he took the next transcontinental express he might arrive in New York in time to get a vessel for Holland. So he came on without buying any clothes, not even a felt hat in place of his straw one. When he arrived in New York he found that no steamer had left, and that no one knew when one would leave. He was vigorously guyed on the streets of New York on account of his unseasonable headgear. The steamship people told him that he [268] 


\section{THE STORY OF AN ENTOMOLOGIST}

must stay in New York, since word from the United States government permitting the departure of Dutch vessels was liable to be received any day. They held him there, five hours from Washington. They finally told him that he might go to Washington for forty-eight hours and that they could wire him in abundant time to return for the boat. He stayed in Washington at the Club for three days. Then the Nieuw Amsterdam was permitted to sail with the proviso that it should take ten tons of corn for the Belgians, and that it should take on board all Hollanders in this country who wished to go home.

In those three days DeBussy told us many interesting things about the life in Sumatra and, what interested us more, many things about the privations which the people in Holland were suffering under war conditions. Among other things, he said that what little fuel they had, consisted mainly of old newspapers soaked in seawater, then dried and cut in briquettes. All petroleum and gasoline had long since disappeared. The head of one of the great petroleum companies in Holland, who had a standing comparable to that of John D. Rockefeller as the head of Standard Oil in this country, and a man who had a dozen automobiles, had broken his leg recently by falling from his bicycle, which was the only possible means of locomotion in Holland. The Dutch were in momentary fear of an overwhelming invasion from Germany. DeBussy said, "We are between the devil and the deep sea, and are having a perfect hell of a time!"

One afternoon in August, 1918, Major Plotz of the Sanitary Corps of the Army called on me at the Club to talk over the question of lice in the camps. He was a young man, and had been in Serbia with the Red Cross Commission as a typhus expert, since he had studied the so-called Brill's disease in Mt. 


\section{FIGHTING THE INSECTS}

Sinai Hospital in New York. He told me that over there he had had the pleasure of meeting Dr. Ivantcheff, whom I had met in Celli's laboratory in 1910, and who had gone with Celli, Dr. Vail and myself on the never-to-be-forgotten journey to the Campagna which I have described elsewhere. He told me that Ivantcheff was in charge of the Bulgarian governmental laboratories, that he had married and had had two children and had grown very gray since I had seen him.

I knew that Ferdinand of Bulgaria was a good deal of a naturalist, and that his name had been removed from the list of honorary members of the Entomological Society of France when Bulgaria entered the war on the side of Germany. Dr. Plotz told me that he had met King Ferdinand on several occasions, and that he had sat with him one evening, listening to the birds' calls, Ferdinand identifying them all from their notes. The King was greatly afraid of disease, and especially of typhus fever. An interesting bit of unrelated history is that on one occasion, after having visited certain Balkan torvns, Dr. Plotz was called before a War Council at which were seated, among others, the Crown Prince of Bulgaria and Field Marshal Mackensen of the German Army. After Dr. Plotz had bowed, the Crown Prince said to him, "You have visited certain towns. Is there typhus present in those towns?"

Dr. Plotz replied affirmatively.

The Crown Prince then asked, "In your opinion, would it be unsafe to quarter troops in those towns?"

And Dr. Plotz again replied affirmatively.

The significance of this inquiry appeared later, since it altered the intention of the Germans and the Bulgarians to concentrate large bodies of troops at these points for the purpose of wiping out the Allies at Salonika, a military maneuver which, had it 


\section{THE STORY OF AN ENTOMOLOGIST}

been carried out, might have proved most disastrous to the allied forces.

\section{Quoted from my diary of February 27, 1918.}

It is a bright, almost spring-like day, with the air rather sharp. I felt under the weather all the morning, a reflex, perhaps, of my last week's trip to Boston and New York-perhaps a touch of spring fever. At any rate, I was rather dizzy and heavyheaded. I left my desk at a quarter after twelve, walked aimlessly down Twelfth Street, stopped in at the Greek's for no especial reason and had my shoes blacked, walked across the street and bought a noon Times, stopped in at a barber shop and got shaved without especially needing it, and walked on up to $G$ Street. The restaurants did not look inviting, so I went on over to the Cosmos Club, in spite of the fact that I knew the dining-room would be crowded at one o'clock.

The Club is too far away from the office for regular luncheon purposes, and I rarely go there unless some one takes me up in a car from the office. Note that I had not intended to go to-day. Note also that I, without necessity and without aim, had had my shoes blacked and my cheeks shaved.

I found a seat at one of the long tables, and presently Mr. Herbert Quick, a member of the Federal Farm Board, a writer of several novels and other books, and a well known economist along agricultural lines, sat next to me. As it happened, I had been puzzling my head about the conditions of the farm loan banks, having a considerable sum of money (for me) invested in their bonds. Therefore, Mr. Quick was exactly the man I wanted to see. He set my mind at rest, and we finished luncheon pleasantly.

As I got up to leave, I saw at the adjoining table Major John 


\section{FIGHTING THE INSECTS}

H. Wigmore, Dean of the Law College at Northwestern University, and the author of "Wigmore on Evidence," a work considered by many the soundest and most brilliant law book published in a generation. The Major stopped me, saying that he wanted to see me and would join me below-stairs in a few minutes.

A year or more before, a rather sumptuous volume had appeared, the title of which I do not recollect for the moment, but which was supposed to be a tribute from American scholars to French scholarship. This work, compiled by Wigmore, was published before the United States went into the war, and proved an incentive to American students to go to France for postgraduate work, since the German universities were closed to them.

When I picked up the book at the Club, I was delighted with its appearance, and prepared to enthuse over its contents. Idealistically, such a book should be written with inspired enthusiasm by men intimately acquainted with France and the French, as well as all departments of French scholarship. But it was distinctly disappointing. In spite of the introduction by President Eliot of Harvard, some of the chapters were not sound, and in those about which I had any real knowledge the writers were semi-ignorant. They wrote without any enthusiasm, and made many blunders, and the effect produced on me was that any one of the men in my office, after a little reading and a free use of "Minerva" could have done rather better. On the spur of the moment I had sat down and written Wigmore a letter, which he never answered-he was awaiting his time to talk to me about it.

So in a few minutes he came down and told me all about the work, explaining the many difficulties he had encountered, especially in the selection of scientific men. He accounted for [272] 


\section{THE STORY OF AN ENTOMOLOGIST}

the apparent lack of enthusiasm by saying that when the book was prepared this country was still neutral. He thanked me on the whole, however, for my criticisms.

While we were talking, my old friend Dr. Maurice Francis Egan, United States Minister to Denmark, came up to shake hands, and in his inimitable Irish way glossed over by European diplomatic experience, began to pay me compliments in French, for which I was very glad, both because Egan is a man much in the public eye, and because it indicated my acquaintance with the French language and, ergo, with French conditions. Wigmore was glad to meet Egan, and we all had a few minutes' conversation, tactfully avoiding the subject of Egan's welcome at Copenhagen to Dr. Cook when he returned to civilization after his supposed discovery of the North Pole.

A moment after, Mr. William Kent, formerly Independent Member of Congress from California, and now a member of the Federal Tariff Commission, whom I had not seen for months, stopped and shook hands, and wanted to chat, but there was no time; so he asked me to play golf with him the following afternoon at the Columbia Club, saying that he would send his car down for me at noon to take me out to his house for luncheon, then on to the Club, where we could have a satisfactory talk.

At that, I started for the doorway, but on the way met Dr. A. B. MacCallum, head of the Canadian scientific commission to the United States on research problems connected with the war. A physiological chemist by occupation, he is rather generally considered the most prominent scientific man in Canada to-day. He caught me by the arm and told me that he had been looking for me, as he wanted me to dine with the Canadian Commission and some picked American scientific men that night at seven 


\section{FIGHTING THE INSECTS}

o'clock. Note that my shoes were blacked and my cheeks shaved for this occasion, in psychological anticipation!

To cap the climax, I met Vernon Bailey and E. W. Nelson of the Biological Survey, two of the best outdoor men in the world, at the hat window, and they brought me back to the office in Bailey's automobile.

This experience is so unusual that it makes me feel rather sore about departmental office hours. I fancy that this sort of thing would happen often if I could go to the Club more frequently. It is the hour just now when all of the men who are doing big things at Washington in connection with war work of every kind are there together.

I knew Robert V. V. Sewell. He did many beautiful things, possibly the most notable being the Canterbury Pilgrimage frieze at George Gould's show place at Lakewood. Once when he was in Washington I put him up at the Cosmos Club, and one Sunday morning, as we were sitting in the big lounge, he said, "I like this room-its expanse and its proportion. I'll tell you what I'll do. If the Club will pay for the paint, I'll do a slightly reduced Canterbury Pilgrimage frieze for it." I thanked him and told him that I would take it up with the Art Committee. As it happened, the Chairman of the Art Committee at that time was Frank D. Millet. I told him with much enthusiasm of Sewell's offer, and to my surprise he almost instantly said that it wouldn't do. He knew the original frieze and said that it would kill any picture in the great room. I realize now that he was right, although at the moment I was mean enough to suspect that there was a bit of jealousy in his decision. Millet's most wonderful painting was hanging on the north wall at that time. It was the sketch for his "Ships in a Fog," for the Baltimore Customs House. It now hangs in the Assembly Room. I told 


\section{THE STORY OF AN ENTOMOLOGIST}

Sewell the decision, and he was kind enough to say that Millet's judgment was probably sound.

Millet spent the last years of his life in Washington, where he had loads of warm friends, as he must have had everywhere. He was the simplest and most unpretentious of men, and about the best mixer I have ever known. I remember that in the summer of 1907, I had Geza Horvath, of the Budapest Museum, and A. Severin of Brussels, as my guests during the Washington visit of the Seventh International Zoölogical Congress. It was in August, and, as my family was at Onteora, we slept at home, but had our meals at the Club. One night at dinner Millet passed us, and I stopped him and introduced him to the distinguished foreigners. He greeted Horvath in Hungarian, and then, turning to Severin, addressed him in Flammand. The Europeans were delighted, and spoke of the incident whenever I met them in future years. They knew that the name was familiar in art circles, but I am not quite sure whether they thought that they were talking to Jean François or to Sir John, as I purposely introduced him in French, pronouncing the name, "Millay."

Millet's fluency in foreign languages was extraordinary. Apropos to this statement, I once told the story I have just related to Charles Francis Adams, and he said that while no one was more fluent in the patter of a number of European languages, Millet's fluency took little account of grammar or form. He went on to say that while he, Adams, was United States Minister to Italy, Millet, who had just finished his work for the old New York Graphic in the Turko-Russian War, called at the Ministry and offered his services as secretary. Adams was greatly taken with him, admired his fluent use of foreign languages, and took him on. Later, at a reception, Adams, talking to the French Ambassador to Rome, apologized for his poor French and suggested that his secretary, Mr. Millet, would put his ideas into much 


\section{FIGHTING THE INSECTS}

better words. The distinguished Frenchman smiled at Adams and said that he knew Mr. Millet, but that he would reserve his opinion on the subject of Mr. Millet's French.

At the Millet Memorial Meeting held in the auditorium of the United States National Museum some months after the dear old chap went down on the Titanic, Mr. Adams made a most laudatory address. He was much affected. His voice trembled, and his eyes were tearful.

Millet liked all kinds of people. One of his favorites at the Cosmos Club was a shy old German, Dr. E. A. Schwarz, who spoke with a strong accent, complicated by badly fitting false teeth, but who had a delightful sense of humor. A story that pleased Millet greatly, and that he often told, was of a little boy who went to Dr. Schwarz's desk in the National Museum and said, "Oh, Dr. Schwarz, here is a very beautiful beetle that I found sitting on a milk-weed."

"Vell," said the dear, learned old fellow, "he's got to sit somevhere, ain't it?"

For a number of years we had in Washington an informal club composed of secretaries of national organizations having headquarters there. Richard D. Watrous, the secretary of the American Civic Association, was the leading spirit, and called the meetings. I went as the secretary of the American Association for the Advancement of Science. Colonel Ernest Bicknell, secretary of the American Red Cross, and about twenty others were usually in attendance. The luncheons were held at the Press Club. Millet, as secretary of the American Academy at Rome, was often there, and the last time I saw him was on the day he left for New York with Archie Butt, the Military Secretary of President Roosevelt, to sail to Europe. It was on that return trip that they were lost. As it happened, that day we were discussing the general subject of a Lincoln memorial. The secretary of the 


\section{THE STORY OF AN ENTOMOLOGIST}

National Good Roads Association was there, and was strenuously urging the Lincoln East-to-West Highway as the most appropriate and wonderful memorial that could be imagined. Millet had strenuously advocated the sufficiency of the beautiful Lincoln Memorial on the Mall. It came time for him to leave to catch his train, and his final words were: "I can understand the pride any man would have if some one were to name a cocktail or a brand of cigars after him, but no one would care about a road."

A story that Brander Matthews once told me at the Players' Club in New York brought in the Millets very prominently. Lawrence Hutton was with us, and Matthews told it rather to worry Hutton. It may have been published, but I have never seen it in print. Mr. and Mrs. Hutton were going over to Switzerland for the summer, and stopped in England to see the Millets, who were then living at Broadways. Soon after they arrived one of the Millet children said, "Oh, Uncle Larry, won't you buy us a donkey?"

"Perhaps," said Hutton. "I will think of the matter."

The next day he returned from London with a cage in which were a pair of rabbits. "You see," he told the children, "I found in London that donkeys had gone out of style; but as the Prince of Wales has just bought rabbits for his boys, I looked about and bought you two of the finest that could be found."

The children were delighted, and promptly named one "Uncle Larry" and the other "Aunt Nellie," after Mrs. Hutton.

On their way home from Switzerland in the autumn the Huttons called again at Broadways. One of the children called out, "Oh, Uncle Larry, what do you suppose has happened to those rabbits that you gave us? Nellie dug out under the hutch and ran away, and Larry-he's had kittens!" 


\section{FIGHTING THE INSECTS}

Two more stories might be added. The Club's first attempt at a dining-room was a simple grill-room in the basement. A capital negro cook named Dangerfield, whose ancestors might have been the slaves of the old Dangerfield family of Alexandria, was engaged, and his cooking was superb, especially all sea foods. One day a newly appointed Chairman of the House Committee went down to look into arrangements, and the following was the conversation:

Chairman: "Well, Dangerfield, how are you getting along?"

Dangerfield: "Fust rate, sah; but dey suttenly is a cu'ious set of men in dis yere club."

Chairman: "How's that? What do you mean?"

Dangerfield: "Well, sah, heah's a case: A gemman come down for lunch, and he ordeh a Spanish mackeral. Foh Gawd, sah, dey wa'n't no Spanish mackeral in de place, but I didn't s'pose de gemman would know de dif'rence. So I tuk a ordinary mackeral, cut off de head and de tail, split it and broiled it up fine, and sont it in by Torm, de waiter boy. Right soon Torm come back and he say, 'Mist' Dangerfield, de gemman say dat ain't no Spanish mackeral.' And I say, 'Torm, you go back an' tell de gemman dat sho is a Spanish mackeral,' and denn Torm come back and he say, 'De gemman say dat he want to see de head and de tail of dat fish.' I didn't s'pose de gemman would know the dif'rence, so I put de head and de tail on de silver waiter and sont it in. Putty soon Torm come back and say, 'Mist' Dangerfield, de gemman got you. He say de gills is de wrong shape and dat dey is too many rays in de tail.' I ask about dat gemman, and I find dat his name is Fedo Gill and dat he know mo' about fishes dan any man in America. I ain't puttin' up no mo' jobs on any of de gemman in dis here club."

The second yarn is also about the old grill-room. One summer evening eight of us were dining together at a big table. As the only Club officer among them, I sat at the head. The weather was hot and the conversation was not inspiring, so the men 


\section{THE STORY OF AN ENTOMOLOGIST}

began to bring newspapers and magazines to the table. This was distinctly not companionable, and I cudgelled my brains for a topic so interesting that it would overcome the influence of the weather. I thought a bit about the other seven men, and found that they were all of New England birth or education. And so I proposed this thesis: All of the New England eccentricities, the running after strange gods from Theosophy to Babbism, the great vogue of Christian Science, the interest in Spiritualism and in strange quackeries of other kinds, and even the New England conscience (which I contended was rather pathological than ethical)-were due to a chronic racial dyspepsia, produced by generations of bad cooking. The warm weather was forgotten, newspapers and magazines were discarded, and for six nights there was intensely animated conversation, accompanied by hammering on the table. I told them, for example, that Boston was the only city in the country in which they did not know how to cook beans, and I also mentioned the famous New England breakfast of doughnuts and pie. They grew greatly excited, and of course, disputed the latter point. I told them that only a few weeks previously, at a private house near Newburyport, I had been given stewed clams and seven kinds of pie for breakfast.

This was long ago, and I have forgotten just who the men were, but I seem to remember that Frank Wigglesworth Clark and Charles S. Munroe, both Harvard men; Carroll D. Wright, then President of Clark University; and Henry S. Pritchard, then President of the Massachusetts Institute of Technology, were four of them, and I am not quite sure but that Herbert Putnam, an overseer of Harvard, was there.

It is difficult to stop talking about the dear old Cosmos Club. I must add some more.

I have met a number of Arctic explorers at the Club. General Greely, the leader of the Lady Franklin Bay Expedition, has long 


\section{FIGHTING THE INSECTS}

been one of my warm friends. Lieutenant, afterwards Admiral, Peary, I knew when he first came to Washington, where he served first in the Coast Survey. Nansen I knew at the Club. Amundsen I met on a transcontinental journey shortly after he had discovered the Magnetic Pole, and later I talked with him in Washington. I came to know one of the members of the Greely expedition, a big young German named Biederbeck quite well, speaking with him frequently after the expedition returned to Washington. Later on, he held a post for a short time in the Department of Agriculture, then joined the Customs Service at the Port of New York. He told me that he was acting as hospital steward at the time of the rescue of the party by Captain, afterward Admiral, Schley. He said that Greely was lying desperately ill in the tent, and that he himself, getting up early in the morning, went out to the flagpole outlook and heard the first whistle and saw the first smoke from Schley's vessel. He ran back to the tent, opened the medicine chest, and poured the last remaining drops of whiskey between Greely's lips. This may have saved the General's life. We old-timers all remember how he was nursed back to health in the hospital at Portsmouth, New Hampshire, by Colonel Head of the Army Medical Corps, who had hastened down from his summer home at Bar Harbor.

One day in the Department of Agriculture lunch-room, Biederbeck introduced me to one of his Arctic companions, Lieutenant Brainard, and we had a long chat. I mention this because of what follows. That night (it was in the winter time) I was going home late from the Medical College and stood upon the front platform of the old horse-drawn street-car, smoking and occasionally stamping my feet. The bearded driver turned and said to me, "It's a cold night." To which I agreed very cordially. And then he went on to say that I ought to wear sealskin boots with the fur inside. I asked him what he knew about such things, and 


\section{THE STORY OF AN ENTOMOLOGIST}

he replied that he had been in the Arctic. I told him about my lunch with Biederbeck and Brainard.

"Oh," he said, "I was on the De Long relief expedition, and we put in at Halifax, where the Greely people were outfitting. A number of each crew met in a bar-room and started a row. The 'blue-nose' police were called in, and both parties of Americans joined forces and cleaned out the police. I remember your man Biederbeck. He was a big young German, and Lord! how he could fight!"

I shall never forget Nansen's first lecture at Washington. After it, a reception was given in his honor by the National Geographic Society at the old Arlington Hotel. Graham Bell, then the President of the Society, introduced General Greely as the appropriate person to introduce Dr. Nansen, since it was he who held "the next Farthest North record." Greely's address was particularly happy. He referred at once to Dr. Bell's words and went on: "I am reminded of an incident of the first America's yacht race off Cowes. Her Majesty, Queen Victoria, had gone down to see the finish. After a time she asked the attending English admiral what news had been received about the vessels.

"Alas, Your Majesty," said the Admiral, "the America seems to be in the lead."

A little later the Queen repeated her question and received the same reply. At length the race was over, and she asked the Admiral which vessel had won.

With great reluctance he replied, "The America."

"Which vessel was second?" said the Queen.

"Alas, Your Majesty," said the Admiral, "there was no second!"

There is an interesting recollection of an incident that occurred as Mrs. Howard and I were just about to enter the lecture hall. Immediately ahead of us in the line was my old friend Dr. Sivan Burnett, and with him a frail little man whom I had met at the 


\section{FIGHTING THE INSECTS}

Club. I told Mrs. Howard he was Frank R. Stockton. As we moved slowly forward, Stockton suddenly began to fall and was caught by Burnett. We were told the next day that he was carried up to one of the hotel rooms, where he died.

Considering the purpose of this book, I have probably given too much space to the Cosmos Club. But it is hard to stop, yet I will do so with the following paragraph from a short address I made at the annual meeting in 1922 :

"Perhaps few of us realize it, but while we are enjoying the Club's homelike atmosphere, which an eminent artist once called one of 'dignified simplicity,' it is broadening to all of us and makes us more interesting to others and more interesting to ourselves. The Fiftieth Anniversary will celebrate the intimate commingling of scientific men and those of the near-sciences of engineering, political and social economy, forestry and archæology; of artists and of writers, of leaders of medicine, law and the church, and of men distinguished in the public service-all brought together to a degree and in a way that no other organization in the world has equalled. Long live the Cosmos Club!" 


\section{Chapter XIV}

T

big, generous soul of Alexander Graham Bell shone out in all his relations with the world. One realized this on meeting him. I think it was in November or December, I886, that I came home after my first introduction to Dr. Bell, filled with a sense of his charm and his broad interest in man and in all sorts of fine things.

The facts about that first glimpse of Dr. Bell are interesting. $\mathrm{He}$ and his father-in-law, Mr. Gardiner Hubbard, had been finarıcing the new weekly journal, Science, and it was a constant money drain. I don't think that they minded that at all, but Dr. Bell wished to know how the journal could be improved and made more interesting to scientific men and to those interested in science. As a preliminary step, he invited those Washington men who had been contributors to the journal (it had been started only a little more than three years before) to talk things over with him at his home. He was then living in a beautiful house at the corner of Rhode Island Avenue and Fifteenth Street. On the night of the conference, Andrew D. White happened to be his guest. Dr. White had retired from the presidency of Cornell University only the year before, and as he and Dr. Bell stood side by side greeting us, the contrast between the two men 


\section{FIGHTING THE INSECTS}

physically was very striking. White was short and slender, already gray, while Bell was tall, robust, with a shock of black hair and a full black beard-a big, strong, powerful man, strongly featured, but with a smile and a charm not to be described in words.

I have been trying to remember who were there. There must have been nearly forty of us, but all have died since that time except a few. Of those still living there were Dr. W. H. Holmes, Dr. C. E. Munroe, General A. W. Greely and Dr. C. Hart Merriam. Among those who have since passed away, were J. S. Billings, J. R. Eastman, G. Browne Good, W. C. Winlock, G. K. Gilbert, T. N. Gill, Major J. W. Powell, F. W. True, O. T. Mason, Simon Newcomb, Henry Gannett, Lester F. Ward, W J McGee, W. H. Dall, H. W. Elliot, C. N. Walcott, H. N. Paul, H. W. Wiley, and F. A. Lucas, thus representing the best that there was at that time in Washington science.

I have forgotten what was said, but I remember that Dr. White greeted us in his charming way, and that the meeting was a most satisfactory one, in that it brought us all together, and gave us an insight into Dr. Bell's character, personality and aims.

Many times since, I have wondered if this especial meeting did not arouse in Dr. Bell the germ of the idea that developed into the wonderful Wednesday evenings of later years. I always meant to ask him about this, but never thought of it at a likely time. I hope that it is so, for I should be quite proud to know that I was there when the idea was founded. Whether it came then or later, it developed into a charming, interesting and highly important series of gatherings that lasted for many years. I did not know that Dr. Bell had begun to bring his scientific and other interesting friends together at his home on Wednesday evenings during the winter months, until I met him one night a few years later at a small gathering at his father's house 


\section{THE STORY OF AN ENTOMOLOGIST}

in Georgetown. As I was leaving, he shook hands with me in his delightful way and said, "You ought to come to my Wednesday evenings. I will send you a card to remind you."

And so, for more than twenty years, a card would come late every autumn: "At home Wednesday evenings." It was always a matter of doubt with me and with others as to how often we should go. Some men, I believe, thought they ought to go every week; some, every other week, while others considered once a month or twice a year appropriate. Occasionally, Dr. Bell would stir up some of us with a second card.

But, however the invitations were interpreted, we all wanted to go every Wednesday evening. At first the attendance was not large. We could be seated very comfortably in the big parlor of the Connecticut Avenue home. But later an extension was added to the south, giving a beautiful room that could be used as a large music-room, or a small lecture hall. Then more people came, and the discussions often assumed a wider range and were of greater importance. I think I must have been there several times every winter. The parallel with the Sultan's forty wives was almost perfect, for every experience seemed more beautiful than the rest. In the series, all sorts of things were discussed, and every subject brought up was usually threshed out by someone who knew all about it.

Dr. Bell would say, "Dr. Blank, we haven't heard from you for a long time. Will you tell us what you are doing these days?" And then Dr. Blank would tell us of the ideas that were filling his mind during his productive hours just then. Many a time the Graham Bell group heard great ideas, wonderful inferences and startling conclusions long before they were given to the rest of the world.

Nothing was ever said about the desirability of not repeating certain things that were told-probably because that was unnec[285] 


\section{FIGHTING THE INSECTS}

essary with such a group of men. I remember that once a member of the Naval Board of Strategy told us the real diplomatic reason why President Roosevelt had just sent the Pacific fleet to Oriental and Australian waters. But the professional diplomatists who were occasionally present said little or nothing, as a rule. Once or twice Dr. Bell suggested that Mr. Robert Lansing should "tell us something interesting." But every time he smiled (I thought rather embarrassedly), and told us nothing.

I remember one night in the nineties when there was a rather small attendance and no one present seemed at all anxious to open up. Dr. Bell turned to Professor S. P. Langley and asked him to tell us of the progress he was making with his flying work. At that time I do not believe that any of us, except perhaps Dr. Bell himself, thought that Langley would succeed. In fact, we felt sorry that so eminent a man should waste his time on the visionary project of flight with a heavier-than-air machine. I recollect, however, how interested we all were in Langley's modest statement of his progress, and I noticed that Dr. Bell was very keen on the subject.

Later Dr. Bell wrote an enthusiastic account of the first flight of the unmanned model over the Potomac at Marshall Hall.

Dr. Bell's deep scientific and personal interest in aviation will naturally be fully displayed in his biography. I am here only mentioning it in an anecdotal way in connection with the Wednesday evenings and closely related occasions. At later meetings the subject recurred many times. McCurdy and other men of that type, in whose ideas Dr. Bell had become interested, were there and talked. And one night he had erected in the front parlor one of the great new tetrahedral kites. Using this as a model, he explained with great enthusiasm the advantages of the multiplicity of the tetrahedral cells.

Long after Langley's death, when the Wrights came to Wash- 


\section{THE STORY OF AN ENTOMOLOGIST}

ington for their public flights at Arlington, I met Orville Wright at one of these evenings, along with the young naval officer, Lieutenant Selfridge, who was killed during one of the first trips aloft.

Later, Santos Dumont, the Brazilian dirigible balloon expert, who first flew around the Eiffel Tower, was there as a guest, and proved to be as quiet and unassuming in his way as were the famous Wrights. Still later, Glenn Curtiss was there, and told us about his newly invented hydroplane.

I think it was at a Wednesday evening at which C. M. Manley, the engineer associated with Professor Langley in his first experiment, was present, that the first suggestion was made that the Langley man-carrying machine whose only experimental flight had failed (nearly drowning Manley), should be braced up, somewhat overhauled and tried once more, as a sort of vindication of Langley. As every one knows, this was done with success.

I wonder if Graham Bell ever made an enemy. It seems impossible. I think that all who knew him must have loved him. He was so catholic in his interests, he was so human, and he was so exquisitely kind. I can not believe that he liked me any more than he did hundreds of others, yet whenever I met him I felt that I was the one person he especially wanted to see. His tact and his careful watchfulness for the interest and comfort of his guests were natural and not acquired. They came from his warm heart and his liking for others.

One night he and Mrs. Bell were giving a reception to the Countess Montessori. The room was crowded, and a long line of people was passing. As I took her hand, I greeted the Countess in a choice Tuscan phrase that I had coined the night before with the help of a skilled Italian scholar of my acquaintance and had carefully committed to memory for the occasion. I had no 


\section{FIGHTING THE INSECTS}

time to listen for her reply as the line was moving rapidly. Twenty minutes later, however, when there was a lull in the arrivals, Dr. Bell, as excited and as interested as a boy, came hastening up to me and said, "Dr. Howard, the Countess is much impressed with you and with your Italian, and wants to talk to you, as she knows no English." I found the Countess standing alone, waiting for me, and immediately asked her whether she spoke French. She said that she did, but that she preferred Italian. Thereupon I explained to her that I had just used all the Italian I remembered in greeting her in the line, and that I had laboriously prepared that for the occasion. She replied in excellent French that it was a great bit of courtesy on my part and that she appreciated it highly. Then we chatted for a few moments in French.

Here is another anecdote which bears on Dr. Bell's human side. A committee of the old Joint Commission of the scientific societies in Washington, just then founding the Washington Academy of Sciences, was meeting for the purpose of counting the ballots for the original seventy-five members of the Academy. It was a very long affair. There were about a dozen of us there, and Dr. Bell sat at my side. About half-past eleven I offered him a cigar. He said, "No, I thank you," pulled out his watch and laid it on the table beside him. The meeting dragged on. Precisely at twelve o'clock he turned to me and said, "Now I will take that cigar if you don't mind," and added, "you see, my physician holds me down to three cigars a day, and when you offered me one a bit ago, I had already smoked my three for yesterday." And the beauty of the thing was that before the meeting adjourned at half-past one, he had smoked his next day's allowance. This happened in February, I898.

Oh, these doctors! If they find that a patient smokes, they either stop it or restrict it, but they never stop smoking them[288] 
selves. It used to be the same way with beer and other alcoholic beverages. Dr. Bell liked a glass of ale or beer, and there used to be an abundance of that sort of thing at the delicious little suppers that always terminated the Wednesday evening gatherings. But I noticed that as the years went on he let the others drink without him. Probably that same conscienceless doctor had again interfered.

One extremely interesting and fruitful discussion took place at Dr. Bell's house, although it did not occur on one of his famous Wednesday evenings. During the Christmas week meeting of the American Association for the Advancement of Science held in Washington in 1902, Dr. Bell consulted me (as permanent secretary of the Association) about the prominent scientific men present during the meeting who should be invited to dine with him. I suggested a number of names, and he added others, and I think that about thirty of us sat down at the big round table. I happened to be seated next to Dr. Daniel C. Gilman, then President of the Carnegie Institute of Washington. His successor as President of the Johns Hopkins University, Dr. Ira Remsen, was, I believe, also present. As usual at Dr. Bell's dinners, it was not long before conversation with one's neighbors ceased and the talk became general, one person addressing the whole table, Dr. Bell, on the opposite side from Mrs. Bell, silently repeating, with his lips only, for her benefit, everything that was said by the man who happened to be speaking.

At luncheon at the Cosmos Club a day or two before, Dr. Gilman had asked me about Walter Reed's Yellow Fever work in Cuba, and he now suggested that Dr. Bell ask me to tell the whole story. Of course I knew Reed, Carroll and Lazear personally-they had consulted me about mosquitoes before they started for Cuba, and Reed had been in correspondence with me during his work down there. Reed had died just a month before 


\section{FIGHTING THE INSECTS}

and this pointed the story. I told the tale of achievement that was to bring about the subsequent abolition of the dread scourge, and of the heroic self-sacrifice involved in Reed's work. I think that Dr. Bell himself suggested that a movement should be begun at once to secure a memorial to Reed and his colleagues, and suitable pensions to their widows. The idea met with enthusiastic response, and an organization was formed immediately to carry out the two suggestions. The late James Fletcher, then Hon. Treasurer of the Royal Society of Canada, was my guest at the time and was present at this wonderful dinner. On our way home he could talk of nothing but this incident, and of his admiration for Dr. Bell and his regret that the latter had not stayed in Canada to help them with such fine movements as he was pushing forward in the States.

The result of the discussion at this dinner was speedy. The next day the American Association for the Advancement of Science passed resolutions reciting the tremendous value of the work of Reed and his colleagues, and authorizing the President to appoint a committee of nine to secure a memorial to Dr. Reed. Dr. Gilman was appointed chairman; Dr. Bell, Surgeon-General Sternberg, Seth Low, Abram S. Hewitt, J. G. Schurman, Dr. S. E. Chaillé, Dr. W. H. Welch and Dr. Charles Sedgwick Minot were the other members.

I was very glad that Dr. Bell's name was included with this committee, as he was the first to suggest the movement. When a few weeks later the Walter Reed Memorial Association was incorporated in Washington, he did not appear as one of the incorporators. Original officers of this association were Dr. Gilman, President; General Sternberg, Vice-President; Charles J. Bell, Treasurer; General Calvin De Witt, Secretary; with an executive committee consisting of Major J. R. Kean, Major W. D. McCaw and Dr. A. F. A. King. Soon afterwards, the Amer- 


\section{THE STORY OF AN ENTOMOLOGIST}

ican Medical Association appointed a committee to coöperate with the Memorial Association, and Dr. W. W. Keen of Philadelphia was made its chairman. A large sum of money was raised by the Memorial Association, and several memorials to Walter Reed are in existence today.

Dr. Bell's Wednesday Nighters were, in a way, an unusual lot of men, and the fact that one was an habitual or an occasional attendant at these meetings stamped him as an interesting person. This fact was at least twice impressed upon me thousands of miles from Washington.

Once, as I entered the dining-room of the charming little Hôtel de la Poste at Rouen, a white-haired gentleman with a familiar face rose from a table where he was sitting with his wife and greeted me: "I am so glad to see you. I have forgotten your name, but $I$ have met you at one or two of Graham Bell's Wednesday evenings." Then, turning to his wife: "My dear, I want to present one of the interesting men I have met at some one of those delightful Wednesday evenings of Graham Bell's, of which I have told you so much." It proved to be Mr. Bunker of San Francisco. I joined them at dinner, and Mrs. Bunker told me of her husband's enormous interest in the two or three evenings he had been lucky enough to attend. She even remembered what he had told her of some particular discussion that he had heard, or in which he had taken part. (I remember one especial evening when we talked of labor troubles, and that Mr. Bunker gave us some illuminative ideas.)

At another time, in Honolulu in 1915, Mr. and Mrs. Alanson Bryan gave a reception in my honor, and the Governor of the Territory and other prominent people came, among them General Carter, in command of the post. Mrs. Carter told me frankly that she had wanted the General to go with her to another reception that was being given the same night in honor of some 


\section{FIGHTING THE INSECTS}

wealthy and socially prominent people from the States, but that the General had said, "No," that he was coming to Mr. Bryan's because he had met me at Graham Bell's, and that he was not going to lose a chance to see "one of those Graham Bell men!" That was a proud moment for me. To be called a Graham Bell man!

If one occasionally had such experiences far away from the States, how much oftener must they have occurred in this country! Quiet and unostentatious as these meetings were, they gradually became famous. This was impressed upon me strikingly one Wednesday morning when I met on a Washington street Mr. Spencer Miller, a New York inventor and engineer, a friend of some years' standing. After greeting him, I asked him to go with me that night to Dr. Bell's. His face brightened and he said, "By George, I have an important dinner engagement for tonight, with a conference afterwards, but it has been one of the ambitions of my life to go to a Graham Bell Wednesday evening, and I will go with you in spite of all the important engagements in the world." And so we went.

It was generally understood (and undoubtedly it was one of Dr. Bell's own charmingly tactful ideas) that when any member of the regular group brought with him an especially interesting stranger, the member was asked by Dr. Bell to "tell us something new and interesting." Then the regular would rise and say, "Really, Dr. Bell, I have nothing to contribute personally, but I have taken the liberty of bringing with me tonight $\mathrm{Mr}$. (So-and-so) who has been working on some big things, and I think he might be willing to talk about them a bit." So that night we went through that pleasant form, and Spencer Miller (really more embarrassed than I had ever known him to be before) told us about his invention for transferring coal from one vessel to another while under headway at sea. It delighted Dr. 


\section{THE STORY OF AN ENTOMOLOGIST}

Bell and greatly interested the rest of us. Mr. Miller later became a member of the distinguished group of men who formed the Naval Consulting Board, organized in the early days of the World War. It may be stated incidentally that at an earlier date he had perfected the cable-carrier system used in the construction of the Gatun Locks of the Panama Canal.

When the Great War came on, it seemed to make little difference at the Wednesday evenings. During the winters of I9I4, 1915, and 1916, Wednesday after Wednesday went by, the same interesting people were there, and, varying from time to time, the same tremendously wide range of subjects was discussed. So far as I know, never a word was said about the War. Good, broad Americans, with well-founded ideas of world conditions, and equally well-founded opinions of other nations based upon wide reading, travel, and intimate personal acquaintance, felt themselves growing more and more restless, more and more humiliated by the inaction of our government. Few of them realized how heavy a burden of shame they were bearing until April 1917, when America went in.

The Wednesday night after this event the Graham Bell circle broke loose. There was no previous sign of it, and no conscious intent. We simply couldn't hold in, and there was no longer any reason why we should. We gathered in the big room, and Dr. Bell turned to me and said, "Dr. Howard, we haven't heard from you for a long time. Haven't you something to tell us tonight?"

I had just that day received a letter from an Italian friend, who had been forced by bronchitis to go with his wife to Capri. I have referred to him at some length in another chapter. $\mathrm{He}$ was at this time too old for military service. In this letter the Duke indulged in a bit of satire that appeared to me to be so exquisite that it stuck in my mind and I quoted it as follows: 


\section{FIGHTING THE INSECTS}

"I wish that you were here sitting beside me, looking down on the islands of the Sirens and lolling, simply lolling. But I fear that this would not comport with the disposition of a onehundred-and-eighty-miles-an-hour American. Speaking of onehundred-and-eighty-miles-an-hour Americans reminds me that your President has not shown such mad velocity in the act of redressing the wrongs of those American citizens whose dear ones went down on the Lusitania. But that incident has at least procured for us literarily-minded Europeans the pleasure of reading exquisitely-penned notes which we trust will eventually be brought together in a book as a companion piece to the 'Fioretti' of St. Francis!" (Mr. Lansing was not present that night!)

It was this that started them. Dear old Dr. S. N. D. North sprang to his feet and gave voice to the patriotic sentiments of all of us, and speaker after speaker followed. There was much moderately restrained excitement.

After a bit, a man unknown to most of us arose and with an accent that sounded to our ears like German, began to speak. He turned out to be Frank Meyer, the agricultural explorer, and what he said was: "You vill think from my agsent dat I am a Cherman, but I am no Cherman; I am no Austrian. I am a Hollander. I haf listened to dese sentiments vith much interest. Von speaker has said that Militarismus is de cause of war-that Militarismus is de cause of all wars. But I tell you, chentlemen, dat dere is somedings dat is a surer and deeper cause of war, and dat is Patriotismus. Patriotismus is always and has always been de cause of almost all wars. What we must work for is not for country, but for humanity. If you t'ink in dis way, you vill become Social Democrats like me."

In my anecdote about Spencer Miller and his Wednesday evening talk, I purposely phrased my concluding sentence: "It delighted Dr. Bell and greatly interested the rest of us," for in 


\section{THE STORY OF AN ENTOMOLOGIST}

these words are expressed a striking difference between him and other people. What interested them, delighted him. I never knew a man with so many enthusiasms. I never knew a man who was so instantly and truly responsive to an entertaining or quaint turn of thought or to a fine new idea. He was as like a child to whom his little world is a Wonderland as it is possible for a great man with a great mind to be.

I thought of Dr. Bell when I heard James Harvey Robinson say, in his address on "The Humanizing of Knowledge," at Salt Lake City in June, I92r:

"Those to whom a commonplace appears to be extraordinary are very rare, but they are very precious, since they and they alone have made our minds. It is they who, through hundreds of thousands of years, gradually enriched human thought. ... Without them, the mind as we know it would never have come into existence. They are the creators of human intelligence. The mass of human kind must perforce wait for some specially wide-eyed individual to point out to them what they have hitherto accepted as a matter of routine or failed altogether to notice. These mindmakers are the questioners and seers. We classify them roughly as poets, religious leaders, moralists, story tellers, philosophers, theologians, artists, scientists, inventors. They are all discoverers and pointers-out. What eludes the attention of others catches theirs. They form the noble band of Wonderers. Commonly unnoticed things excite a strange and compelling curiosity in them, and each new question sets them on a new quest."

Voltaire once wrote, "Inventors will always hold the first place in the memory of mankind." This must be apparent to every one, and, as the originator of a great invention of enormous value to the human race, Graham Bell's memory will live for all time. But those who knew him, who were inspired by him, who were made better and happier through having met him, even rarely, must deeply regret that they cannot pass on to posterity the 


\section{FIGHTING THE INSECTS}

knorvledge of the rare and beautiful personality, the distinguished achievement, the great intellectual qualities of this man who still was filled with a youth that made no count of years. ${ }^{1}$

Undoubtedly there have been in Washington, groups of people who have held weekly or occasional meetings that in a way, perhaps, approached in interest and importance the Graham Bell Wednesday evenings. There was, for example, the old Literary Society, of which I was not a member, but to the meetings of which Mrs. Howard and I were occasionally invited.

Then, too, there was a small and exclusive group of people that for some years met from time to time at the home of Henry Adams. It is well known that Mr. Adams shunned publicity, and only a few people knew him. Although he was an original member of the Cosmos Club, I do not believe that he ever visited that institution. At all events, although I joined early in I886, I never saw him there, and, in fact, never met him. But I have heard that he was a delightful host, and that the small group who went to his "evenings" considered themselves very fortunate.

Eventually, there grew up another organization that became known as the Round Table Club. It deserves special mention.

Herbert Putnam is a very distinguished man and a charming gentleman. He must, by now, be approaching the retiring age. After much experience in library work at Minneapolis, Minnesota, and in the Boston Public Library, he was placed in charge (about 1909) of the Library of Congress. Since then, he has made a truly national monument of that institution, and has set the pace for all of the great libraries of the country.

${ }^{1}$ I wrote what precedes in this chapter after Graham Bell's death, at the request of his family, and 1 understand that it is their intention to use it in a biographical volume. It is published here with the explicit permission of Dr. Gilbert Grosvenor, Dr. Bell's son-in-law. 


\section{THE STORY OF AN ENTOMOLOGIST}

All this is well known to people in general, but only the elect know of the Round Table Club. Dr. Putnam started this as a lunch club soon after he came to Washington, and the principal heads of the departments in the library, and the near-by elect, like Henry Pritchett and O. H. Tittman of the Coast Survey and others, got together about a round table and had luncheon, at first daily, and later from time to time. The group was enlarged, and literary, artistic and scientific celebrities dropped in, until the Round Table Luncheon became a unique function. Conversation was general. Controversial subjects were avoided. Wit and good humor abounded.

I was invited to be a member many years ago, but since the Department of Agriculture was so far away, I seldom went, only, in fact, when something especial was going on, such as the presence of some particularly distinguished man, or when I had a famous guest and took this chance to introduce him to the right group. In fact, in a somewhat different way, the Round Table paralleled Graham Bell's Wednesday evenings, for while, on the whole, it was perhaps as entertaining, it was less informative.

On November 7, 1919, after an interruption of several years, due to the War and to Dr. Putnam's activities in Europe, a group of the members in Washington held a meeting, and made it special in that a loving cup was presented to Putnam for his leadership in the institution. It was a remarkable group. Ambassador Jusserand of France; Secretary Lane of the Interior Department; Mr. Justice Holmes of the Supreme Court; David Jayne Hill, ex-Ambassador to Germany; Thomas Nelson Page, ex-Ambassador to Italy; Dr. Garfield, president of Williams College and coal administrator during the war; Assistant Secretary Roosevelt, and a number of others (thirty-five in all) were there.

That delightful man, the Reverend Dr. Roland Cotton Smith, 


\section{FIGHTING THE INSECTS}

took the chair and in his very impressive way, which is an extraordinary combination of the conversational and the thoughtful and humorous, intensified by his partial stammer, began something like this: "Dr. Putnam for many years has been handing out books in decent and ... [pause for a moment] beautiful bindings." And then he went on, but the pause was enough to horrify his hearers, and the burst of relieved laughter that followed the latter words was very hearty. He spoke of Putnam's wonderful work in the library, and especially of his organization and carrying through of the enormous library service among the troops in France. He showed that five millions of volumes, if I am not mistaken, were circulated among the men, and that the books they chose were on the whole serious, rather than light.

After Dr. Cotton Smith, Thomas Nelson Page spoke at some length, and then Ambassador Jusserand made a gem of a speech. Jusserand was an extraordinary and charming man. During the luncheon, I told him that I was going to France in the spring after an absence of seven years. His eyes sparkled with pleasure as he said, "It is not as bad as you think, even in the devastated area-reconstruction is going on so rapidly. I heard only yesterday that although in this area four thousand four hundred schools were destroyed, last month three thousand of them were in full operation."

There was still another assemblage of men that bears mention. I have told of it before-an informal luncheon club, the members of which were all secretaries of national organizations that had headquarters in Washington. One of the last meetings of this organization was held during the early years of the Great War. Lord Aberdeen was the principal guest and told us some stirring things about conditions at that time in England. 


\section{THE STORY OF AN ENTOMOLOGIST}

ADDENDUM

Last September I had an interesting experience that may very well be added to this chapter (I am writing in the south of France in February, 1932). On a trip around the world, while my steamer was in the harbor of Kobe, Japan, the American Vice-Consul, Mr. Coville, son of my old friends, Dr. and Mrs. F. V. Coville of Washington, was good enough to come on board to see me. The Vice-Consul, who was a charming young man, invited me to go out with him to his summer home in the mountains outside of the city. I gladly accepted, especially so as I remembered that his wife is a daughter of Dr. and Mrs. Gilbert Grosvenor. Reaching the delightfully situated bungalow away up in the woods, I met their pretty little daughter-a child of about five years. While I had known neither of the young couple before, it was brought out at dinner that in the comparatively short space of fifty years I had known personally no less than five generations of Mrs. Coville's people. Old Professor Melville Bell and Mr. and Mrs. Gardiner Hubbard, the great-great-grandfathers and great-great-grandmother of the child, I knew rather well before they died in Washington. Then I knew still better her maternal great-grandfathers, Alexander Graham Bell and Professor Grosvenor of Amherst and their wives; and of course both of her grandfathers and grandmothers, Dr. and Mrs. Gilbert Grosvenor and Dr. and Mrs. F. V. Coville. In fact, I had always looked upon all of these grandparents as much my juniors. Wasn't it curious? It was unique in my experience, and I think would be very rare in any one's experience. Incidentally, it made me feel old. 
Chapter XV

\section{I}

HAVE been reading through the manuscript of the preceding chapters, and I see that I have omitted to tell about many incidents that were quite as interesting as those that I have mentioned. But there should be a limit to the ramblings of an elderly man. This chapter will therefore contain a few things that may seem out of place, but that would have extended some of the chapters, and it will also include a brief account of some recent experiences.

I see that Chapter II as I have written it is rather too long. Certainly it is too long to be added to. And yet there are one or two things that really ought to be said concerning the period from the spring of 1879 until the spring of $188 \mathrm{I}$, when Comstock was chief of the Service. One of these is of special interest from the viewpoint of practical work with insects.

In the late I870's and early 1880's, great damage was done to the clover seed crop in the eastern United States by a little midge that laid its eggs in the flower heads of red clover. The hatching larvæ devoured the contents of the seed-pods. It was the custom in those days in New York and adjoining states to cut three crops of clover annually. The first two were cut for hay and the third largely for seed. The third crop was the most important 


\section{THE STORY OF AN ENTOMOLOGIST}

and the most valuable. But it was found that by the time the third crop was cut, practically all the seeds had been devoured by this pest. We had studied the development of the midge and knew its exact periods of transformation. It occurred to me to investigate the crop-cutting times in relation to the insect transformation times, and I soon found that if the time for cutting the first crop were advanced ten days, the remaining two crops would not be attacked, and that perfect seed rould be developed in the third crop. This was published (under Comstock's name, of course) with the result that the Clover-seed Midge soon became a pest of slight importance.

This, I think, was the first time in the United States that crop practise had been altered solely to avoid insect damage. And it was a good deal of an achievement.

The working out of the life history of the Midge was largely done by Theodor Pergande. I helped, but Pergande made the close observations. The little man (he was only five feet two in height) was invaluable for many years on account of his close and careful studies. In fact, Cooper Curtice once remarked that the Bureau of Entomology without Pergande would be like the play "Hamlet" without Hamlet.

I promised on earlier pages to say something more about Pergande. In his younger days he was a mechanic in the great gun works at Stettin, in Prussia. Disgusted with the idea of war and war implements, and not liking the intensely religious attitude of the people who surrounded him, he came to America just before the outbreak of the Civil War. He landed in New York with no English and very little money. He did not know where to go. He found his way to the Grand Central Station, fell into the line at the ticket office and noticed that the man ahead of him bought a ticket for Syracuse. The word Syracuse sounded familiar, so he, too, bought a ticket to that point. $\mathrm{He}$ 


\section{FIGHTING THE INSECTS}

arrived in Syracuse early in the evening, wandered about the streets, homesick for the German tongue, and presently found himself before a chapel where he heard German spoken by the people passing in. So he, also, entered the church. Behold! he was back in the religious atmosphere. He spoke (in German, of course) to the young man who sat next to him, found him agreeable and went home to spend the night with him at his boardinghouse. The young man had no job, and when, on the next morning, while walking together through the streets, they saw a recruiting station, they both volunteered, adding their names to the first three hundred thousand recruited for the war. So, by the irony of fate, twenty-four hours after he landed, he found himself back in both the religious and warlike atmospheres.

At the end of the first three months, the enlistment having expired, Pergande's new found friend went back to New York, but the immigrant, with characteristic perseverance, stuck to the army for the full four years of fighting. At the end of the war he was discharged at St. Louis, and, having no other trade, went into the big gun works there. He had always been an amateur entomologist, collecting butterflies and beetles and such things, and on one of his Sunday afternoon collecting rambles he met Otto Lugger, then Riley's assistant. Lugger was about to resign and recommended his friend for his job. So Pergande stayed with Riley, and came with him from Missouri to Washington in 1878 , where he remained until the time of his death in the early 1900's.

I was much interested in letters on the subject of Spiritualism published from time to time in the English journal Nature, especially those that appeared in 1926 and 1927 . Possibly this interest was intensified by the fact that my esteemed friend, Dr. Robin J. Tillyard of New Zealand and Australia, entered the field on [302] 


\section{THE STORY OF AN ENTOMOLOGIST}

the affirmative side and was answered by Bryan Donkin and E. J. Dingwell. I have not read the seriously intended writings of Sir Oliver Lodge, Mr. Alfred Russell Wallace, or Sir Arthur Conan Doyle, nor was I at all impressed by the much earlier writings on this subject by my friend, Hamlin Garland. One reason for my indifference arose from a personal experience with Alfred Russell Wallace in Washington in 1892 or 1893 . That experience prepared me to believe in a general way that whenever a sound scientific man reaches a certain age and begins to think much of the possible hereafter, he is likely to lose his scientific acumen and is almost as easily deceived as are people of no scientific training.

Wallace was in Washington in the springtime of one of those years. I had met him at the Cosmos Club and at the Biological Society, where he was good enough to speak appreciatively of a paper I had read. He was a friend of my Chief, C. V. Riley, and he asked the two of us to attend with him a Spiritualistic séance given by a man named Keeler, at a house on Ioth or I Ith Street, just above Pennsylvania Avenue. Old General Francis J. Lippett, a confirmed spiritualist, went with us.

About thirty people were present. We paid fifty cents each. All except Wallace, Riley and myself were evidently habitués, and Wallace was known as a believer. A corner of the room was curtained off to a height of about seven feet. Behind this curtain was a table on which were a tambourine and other things. In front of this curtain were seven armless chairs in a row. What Keeler called a "battery" consisted of seven people seated in these chairs, with a curtain drawn in front of them so that all but their heads was obscured. Each person in the row held the wrist of the person next to him or her, Keeler himself forming one of the group, being seated the third from the right. At first the battery was composed only of believers. General Lippett turned 


\section{FIGHTING THE INSECTS}

the gas down very low, seated himself at a cabinet organ, and we all sang softly "In the Sweet By-and-By."

The tambourine began to rattle, and there was a general commotion behind the inner screen. Presently individuals were asked by name to hold a paper pad forward, close to the screen. Then a hand appeared which wrote messages, all of a satisfactory kind. Finally the chairs were jerked from beneath the two persons on either side of Keeler (by a belligerent spirit), and General Lippett turned up the gas.

In the following interval Riley said something to indicate his disbelief, and it was feared that the séance would not go on because of the sensitiveness of the spirit. But it was tried. Though I had been careful to show no incredulity, I was surprised, somehow, when Keeler chose me to be one of the next battery. He placed me on the extreme right end of the line. I held the right wrist of the lady next to me with my right hand. My left hand was free. The same performance went on as before (after a longer delay). I was close to the "materialized" hand that wrote the messages, and in looking at it closely, noticed a slight deformation that appeared every time, although each hand was supposed to be that of a different person. When I thought that we were about through, I took a firm grip of the rung of my neighbor's chair with my left hand, so that when the spiritualistic pull came suddenly and violently on her chair, I counteracted it with all my strength (and I was strong in those days). I could see that this discomposed Keeler, and when the lights went up and we were released from the battery I walked up to him and asked to see his right hand. I noticed the slight deformity at once, but said (for courtesy's sake), "Yes, it is quite different from the materialized hand."

He replied, "Of course," and looked me in the eyes in an [304] 


\section{THE STORY OF AN ENTOMOLOGIST}

appealing way, as if to say, "You're on, but don't give me away, old man."

Is it surprising that after that performance, and after seeing that Wallace was greatly pleased and fully deceived, I should hold very lightly the opinions of other great men who have become converts? That whole performance was a very transparent fraud.

A few years later I became well acquainted with Colonel I. Edwards Clark, a well-placed man in Washington society, who was almost childishly credulous about such things, and who took me to one or two séances conducted by his favorite woman medium.

In writing of Cornell University in one of the early chapters, I mentioned Professor Bernard E. Fernow, then Professor of Forestry, and promised to say something more about him. The dear old fellow died at Toronto, Canada, in the spring of 1923, at the age of seventy-four. A long article about him was published in the journal Science for March 2 of that year. He was a man of great culture and charm, who came to America shortly after the Franco-Prussian War. His coming was a personal protest against the militaristic policies of Germany. He had served through the war, and was one of the ten thousand troops especially selected to enter Paris after its surrender. He married a charming Brooklyn woman named Goodyear, and they raised a large family of fine children. They came to Washington in 1886, where he organized the Forestry Service of the Department of Agriculture. They lived there for twelve years, until he was called to Cornell to organize the first forestry school in this country.

Fernow was prominent in scientific circles in Washington. His broad culture and his fine mind made him a figure of note. 


\section{FIGHTING THE INSECTS}

He actively discussed big questions in the Biological Society, and also attended the Entomological Society, where he helped to broaden the talk into the bigger phases of biology. His illustrated lecture on "The Battle of the Forest," given at one of the Saturday afternoon public functions of the Biological Society at the National Museum, was very notable. President Schurman consulted me about his appointment at Cornell, and I pointedly remarked that, entirely aside from Fernow's high standing in forestry, it would be a big thing for Cornell to have a person of such culture in its faculty, on account of the unconscious influence that such a man exerts, not only on the students, but on the other members of the professional staff.

He had been there but a few years when the State stopped appropriations for the school, because of the protests of wealthy landowners in the Adirondacks against the system of reforestation that Fernow was introducing on public lands adjoining their holdings.

I was a trustee of Cornell at the time, and I tried to induce the Board to continue the school even without the State appropriation, on the ground that they had practically guaranteed the course to the students already enrolled, and on the ground also that the first forestry school in the United States should not be abandoned in a cowardly way. I argued the question at length and there was a heated discussion. Ex-Governor Stewart L. Woodford was in the chair and was about to put the question after my final speech when President Schurman interposed and took the wind quite out of my sails. He jumped to his feet and said, "Before this question is put, I should like the Board to know on whose advice I recommended Dr. Fernow as the first Director of the School of Forestry. It was done on the advice of the late Abram S. Hewitt of New York and of Dr. L. O. Howard of Washington." The question was put and I was de- 


\section{THE STORY OF AN ENTOMOLOGIST}

feated. Clear-minded Ruth Putnam and one other voted on my side. Mr. Schurman's remark made it appear that I had been making a personal fight for my own nominee rather than discussing the question broadly from the angle of University policy.

Later I recommended Fernow for the forestry school at Toronto, where he died as Professor Emeritus. In the early days of the World War I was appealed to by the governing body of Toronto University for information concerning his personal prejudices in regard to the land of his birth, and I like to think that what I wrote then had some weight. He was a loyal American. Let me tell a story. When the British Association for the Advancement of Science held its meeting at Toronto in 1898 , the members from England were invited by the Canadian Pacific Railway officials to go to the Pacific coast as the guests of the Company. Fernow was up in the Canadian woods, making forestry observations, and he joined the party at Banff, I think. One of the Englishmen, Poulton, was a great mountain climber-one of those strange men who collect mountains as a boy collects postage stamps. Seeing a promising big peak, Poulton challenged the party to climb it. None of the Englishmen accepted the challenge, but Fernow (who was born a German, mind you!) said that as an American citizen he would not allow himself to be bluffed by an Englishman.

They started and climbed most of the day. Then they decided to return. Fernow incautiously stepped upon an inviting green slope and slipped down toward a precipice of unknown depth. He managed to stop his downward plunge and to edge his way to one side into a rocky gully, from which he joined his companion. When finally, about sundown, they arrived at the foot of the mountain, they found the group of Englishmen awaiting them, fearful that something had happened. Marshall 


\section{FIGHTING THE INSECTS}

Ward, the botanist of Cambridge University, exclaimed with anxiety, "Did you encounter the avalanche?"

"Yes," said Fernow; "I was it."

A good many interesting and important things were done in entomology during the period we have been considering. We have pointed out that large agricultural crops-in fact, agricultural industries-have been saved from probable extinction by certain pests, by the introduction of parasitic and predatory insects. But beneficial insects have been used in other ways. It was during my time that the production of clover seed was made possible in New Zealand by the introduction of the Humble Bee from England. Another instance of this general nature in which I had a very strong interest occurred just at the end of the last century.

The Smyrna fig of commerce is a very superior article. It contains an enormous number of small seeds which are said to give it a medicinal quality. Californians, who were growing another kind of fig, were not satisfied with it. Out there they are always trying to do something bigger and better than other people. So for a number of years they grew the Smyrna fig tree. But as the so-called fruit is nothing but a large flower receptacle, they had no results. Then it became known that there was a fruit called the Capri fig which bore only male flowers, and that it was necessary to have the Capri figs near the Smyrna figs in order to secure fertilization. So Capri figs were introduced and planted in several places, among them National City near San Diego; Niles, not far from San Francisco; and Fresno, in the San Joaquin Valley, where a young man named George C. Roeding planted about six hundred of them. When these trees grew up and blossomed, he introduced pollen into the Smyrna figs by using a quill. In this way, he succeeded in fertilizing 


\section{THE STORY OF AN ENTOMOLOGIST}

them and in growing a small quantity of good fruit. But this would not do commercially.

Out in Smyrna, at a certain season of the year, the inhabitants have been picking the Capri figs, and carrying them down into the Smyrna orchards, with the result that minute insects covered with pollen, issuing from the Capri fruit, would enter the Smyrna figs and fertilize them. No one knows how old this process is. Miss Ellen Semple, the ethnogeographer, while studying the history of agriculture in the Mediterranean Basin, told me once that she saw this process described by an ancient Greek author. Certain botanists said at one time that this was all nonsense, but Count Solms-Laubach, a famous German botanist living in Italy, studied the question, and proved the correctness of the old legend which had passed into modern practise in Smyrna and elsewhere in that region.

A man of science living in San Francisco, Dr. Gustav Eisen, worked for a while with George Roeding at Fresno, and from time to time attempts were made to import the insects. In fact, once George Roeding went to Smyrna himself. But all attempts were unsuccessful. The Department of Agriculture at Washington became interested. I was ordered to take up the matter, and in I898 I visited California with the fig fertilization question very much in my mind.

As it happens, Dr. Walter T. Swingle, a botanical expert of the Department of Agriculture, was in South Europe at that time on leave. Through Solms-Laubach, he became interested in this question, studied the crops carefully, went to Algeria, and there at a period that he judged to be just right, he picked Capri figs, sealed their openings with wax, and shipped a lot of them to Washington, whence they were forwarded immediately to Roeding at Fresno. I happened to be in Fresno when they arrived. Roeding and I opened them. We found the fig 


\section{FIGHTING THE INSECTS}

insects alive and healthy. But $\mathrm{I}$ also found among them specimens of a destructive parasite known as Philotrypesis. I pointed these out to Roeding and told him that he must destroy them. Then I went forward on my journey. The little fig insects (known as Blastophaga grossorum) survived. Roeding carried their descendants through the winter in his Capri fig orchard. Next summer my learned assistant, Dr. E. A. Schwarz (who had studied the available literature carefully), went out to Fresno and spent the whole growing season helping to organize a proper method of handling the insects. He and Roeding did just about what the people out in Smyrna had done for years. At the right time, eight or ten of the little Capri figs were fastened to a horizontal stick, and these sticks were hung in the branches of the Smyrna fig trees.

A good crop of very superior Smyrna figs was the result, and thus a successful new industry was started in California. The trade name of this fruit, decided by prize competition, is the Calimyrna.

This rather fascinating story was published with numerous illustrations in the Year Book of the U. S. Department of Agriculture for 1900. It is available in almost any big library. The main credit for this fine achievement must be divided between Dr. Swingle and Mr. Roeding.

A humorous and very embarrassing incident occurred in 1909. I wonder if any of my American friends have ever experienced anything quite so awkward. One day in August of that year Major W. H. Wiley, then a member of Congress, and a famous raconteur and joker, came into the Cosmos Club and invited Dr. H. W. Wiley, at that time Chief Chemist of the Department of Agriculture, and myself, to take a ride with him in his automobile. We went out and found the Major's wife and another 


\section{THE STORY OF AN ENTOMOLOGIST}

lady in the tonneau. Dr. Wiley sat between them, I sat immediately in front of them, and the Major sat with the chauffeur. After we had started, Dr. Wiley pulled out a box containing the cross of the Legion of Honor, showed it to the ladies, and remarked that the Major had introduced a bill in Congress to permit him to accept it. I jokingly leaned forward and asked the Major if he would introduce a bill for me when I got my decoration. The Major replied, "Yes, I'll do it tomorrow, Doctor." I supposed that he understood the joke, but, to my horror, I discovered two days later that he had introduced such a bill and had left Washington. I was petrified and thought of all possible means of stopping the publication of any notice of such a bill. I telephoned the clerk of the Congressional Committee that it was a mistake, and even thought of going to the French Ambassador and explaining, lest some one in the Embassy should learn of the bill and correspond with Paris, to the utter destruction of all the respect of my many friends in France. But I found that the Ambassador was away for the summer and concluded that it was better to say nothing about it. As a matter of fact, it was overlooked, the bill was never resuscitated by the Committee (very possibly the clerk to whom I had telephoned had destroyed it), and the incident ended. I did, however, get the decoration sixteen years later, and my friend, Dr. H. W. Temple, annually introduced a bill to permit me to accept this and other decorations. None of these bills has ever been reported out from the Committee, and the insignia still rest in the safe of the State Department, where my daughters will find them after my death. Even now I can't have them, since I am on a pension.

Of course, as a good American citizen, I don't want to wear crosses and things, but, after all, it seems rather an absurd way 


\section{FIGHTING THE INSECTS}

to enforce loyalty on the part of public officials, or at least to prevent an insidious form of bribery.

I have served under many of the heads of the Department of Agriculture. In the old days, such an official was called the Commissioner of Agriculture, and the department itself was not a full-fledged department. It was one of the so-called independent offices, and was not represented in the Cabinet. During President Cleveland's first administration, however, it was made a cabinet office, and since then the head man in the department has been called Secretary of Agriculture. I have served under nine or ten of them, including no less than twelve years under Secretary James Wilson, the longest period in the history of the republic for which a Cabinet minister has held office.

When I first came to Washington in November, I878, General William G. Le Duc of Minnesota was Commissioner. He signed my first commission. It is a beautiful indication of a youth's wrong estimate of time, that then, at the age of twenty-one, I looked upon the General as a man of advanced years. He must, however, have been only fifty-five, since when he died, in 1917, his age was given as ninety-four. Perhaps, after all, an outdoor life and golf keep a man young for a longer time than was formerly the case. I saw very little of General Le Duc during his term of office, but once in a while he used to come up to the rooms occupied by the entomologists, bringing with him some distinguished guest, usually a Westerner. He would walk up to the insect collection contained in closed bookform boxes on shelves, open a box that occupied a certain place, and show his guest the then famous Rocky Mountain Locust that had done millions of dollars' worth of damage to the West during the years 1874 to 1876 . The Department was a very small affair in those days, and there was little to show guests, but the Gen- 


\section{THE STORY OF AN ENTOMOLOGIST}

eral considered this one of the important exhibits. In fact, he was rather proud of his ability to pick out the right box, since only the Latin names were written on the labels. Noticing this harmless pride on his part, we changed the boxes and substituted a box of butterflies for the grasshopper box. In a few days the General appeared, and made a great show of reading the Latin names on the outside of the forms. Finally he said, "Ah, here he is," and he picked out the box of butterflies and opened it before his guest. The guest remarked with a broad grin, "General, that's one on you!"

Le Duc really started some good things in the Department. $\mathrm{He}$ was the first man to protest against the absurd seed distribution that used to go on in those days. He started the cultivation of tea in South Carolina, and originated the branches of the service that eventually developed into the great Bureau of Animal Industry and the very competent Forest Service.

At one time during his term of office he was elected foreign member of the National Agricultural Society of France, and years later I received the same honor. The Society was eventually changed to the Académie d'Agriculture de France, and the General was retained on its list as a foreign member until the time of his death. He was proud of this honor, and always referred to it on his occasional visits to Washington.

Apropos to General Le Duc. Here is a curious little anecdote that shows the lack of knowledge that existed in scientific circles in France at that time, as to English and American conditions, and it illustrates also a certain carelessness on the part of certain foreigners as to the exact use of American addresses. There was a little natural history journal published in Washington by the old Potomac Side Natural History Club, which bore the name Field and Forest. This journal exchanged with certain European journals, among them a French publication 


\section{FIGHTING THE INSECTS}

that for many years after the death of the American journal came regularly to the Department of Agriculture addressed as follows: Monsieur le Duc de Field et Fôret, Washington, D. C. In some way they had found out that General Le Duc was the head of the Department of Agriculture, and got it into their heads that he was the Duke of Field and Forest.

At the time of his death I wrote a short account of his life that was published by the French Académie d'Agriculture.

After the World War the newspapers frequently hinted at the existence of an important personage who was wielding tremendous influence in the world's affairs, although he was very slightly known to the public. He was often referred to as "The Man of Mystery," and his name was Sir Basil Zaharoff. The English Who's Who, 1921, stated that he was a Knight of the Grand Cross of the British Empire, was holder of the Grand Cross of the French Legion of Honor, and was a banker of Paris. He was generally said to be the man who put King Constantine back on the throne of Greece, who financed a couple of Greek wars and who, whenever he got a new idea, visited the proper Premier and "put it across." He was further said to have been born of a Russian father and a Greek mother, but to have been French by nationality and English by education. It was also stated that he was fabulously wealthy, owned banks and theaters and half of Monte Carlo. All this and a lot of other gossipy things appeared in print, but Sir Basil neither replied to attacks nor noticed gossip. He remained "The Man of Mystery." This fact may warrant the introduction here of the following.

In June, 1920, at a séance of the Académie des Sciences at Paris, I was sitting with Paul Marchal, when Henneguey came up and told Paul that Sir Basil would see him on Thursday at 


\section{THE STORY OF AN ENTOMOLOGIST}

ten o'clock. Marchal asked him to get word to Sir Basil that he would like to bring me with him. When I asked who this individual with the Russian name and the English title might be, they told me that he was a man who had suddenly come into the public eye through services to the Allied governments. During the war he had made large gifts to France and England. The arrangement was made, and Paul and I called at the palace in the Avenue Hoche, and were conducted through tapestry-hung halls and chambers into a waiting-room, where we were interviewed by a French secretary. Presently Sir Basil appeared. $\mathrm{He}$ was tall and straight and gray-haired, with a gray mustache and goatee, kindly blue eyes and a charming manner. He spoke English with an Oxford accent. He was very responsive and rather deferential to Marchal's high standing as a scientific man. He was proposing to give the French government money to assist Marchal's branch of the service. He was especially interested in flies and wanted the government to investigate all kinds of them. Marchal told him that I had written a book on the subject, and showed him his own personal copy. Sir Basil expressed the greatest interest and asked if he might have the book. I told him that I would send him one from London later in the summer. That was all there was to the interview except that I left with the feeling that he was deeply interested in me and would do anything for me. That was his manner. It was nothing but manner.

In August, in London, I called at Mr. John Murray's to buy a copy of the English edition of the housefly book, but found it was out of print. I wrote a letter to Sir Basil and told him I would send him a copy of the American edition when I returned to the States. I received no reply. A few weeks later in Washington, I wrote to New York and instructed my publishers to send him the book and at the same time wrote him a letter of 


\section{FIGHTING THE INSECTS}

advice. I suggested that if he wanted to help the French government one of the best things he could do would be to buy the property at Menton which the Ministry of Agriculture was then occupying as an Insectarium. (It has long since been sold.) Again I received no answer. At the time I considered this very discourteous and made up my mind that Sir Basil was a good deal of a fraud. Now it seems to me that he was pulling too many wires in very great things to bother about corresponding with a chance American, even though he had been brought to his place by one of the distinguished men of science of France.

An episode that I shall never forget concerns itself with Dr. Nicolas Cholodkowsky, an eminent Russian entomologist, who was almost equally famous in his own country as a poet. He was professor of zoölogy in the military school at St. Petersburg. I had long known him by correspondence, and fortunately we had exchanged photographs. Unfortunately, however, I missed him on the occasion of my visit to St. Petersburg in 1909.

After the Second Revolution in Russia (I think it must have been in 1920) I received a letter from Cholodkowsky, written in Riga. It must have been sent by hand across Siberia and mailed in Japan, since the envelope bore the Tokio postmark and a Japanese postage stamp. In this letter he told me that he had lost his post and his pension, and that he was in dire financial difficulty. He must have been about sixty-five years of age at the time (perhaps a bit younger) but said that he felt that he had ten good working years before him, and that he wanted to work in some other country. Could I get him a post in the United States? It was an intensely interesting letter, and I was anxious at once to have him in the United States, since his published work had been of so high a character. A post under the Federal 


\section{THE STORY OF AN ENTOMOLOGIST}

Government was out of the question on account of the regulations of the Civil Service, and so I began to make efforts in other directions. I entered upon a long correspondence with Russian scientific people who had fled their country, and who were known by me to be living in many different parts of the world. I'll not mention their names, but in this correspondence I found that there was among them a perfect acquaintance with the doings and whereabouts of prominent Russians in different parts of the world. I had letters from London, Paris, Budapest, and New York. I also corresponded with Americans in the larger universities and research laboratories.

During this time I was playing golf one afternoon at the Columbia Club with William Kent of California, a remarkable and extremely interesting man, about whom I should greatly like to write much if I had the space. ${ }^{1}$ On the nineteenth hole (well known to all golfers), having Cholodkowsky's letter in my pocket, I showed it to Kent. He read it. "By George!" he said. "This is the most interesting human document I have ever read. I am lunching with Charley Crane tomorrow. Let me take it with me and show it to him." Knowing that Mr. Crane was a man of wealth, and the financial backer of the Woods Hole Marine Biological Station, I readily agreed.

The next afternoon at my office I was called to the telephone. Kent's voice said, "I have shown your Russian friend's letter to Crane, and he is enthusiastically interested. He says that if you can get the man over here he will see that he gets a job at Woods Hole." Then he hesitated for a moment and added, "How can he get over here? How much would it cost?" I

'William Kent's biography, I am informed, is being prepared. A book that he wrote before he died entitled Reminiscences of Outdoor Life was published by Robertson's in San Francisco in 1929. 


\section{FIGHTING THE INSECTS}

answered that I did not know about Cholodkowsky's family, but that I imagined that twelve hundred or fifteen hundred dollars would be enough.

"Well," said Kent, "I'll be responsible for that." And after a momentary hesitation, he added, "If I can't get it out of Charley Crane." The last phrase was one of Kent's characteristic jokes.

I was greatly delighted, and, meeting Kent next day, we talked about the matter. The first question naturally was how to get the money over to Riga. Kent said, "My old friend, Ira Nelson Morris, is U. S. Minister to Sweden. I think he could do it for us." So I wrote to Mr. Morris, and I wrote also to Cholodkowsky.

In course of time I received answers from both. But in the interval Kent's health had broken down, and he had gone off to the South Pacific. Then, to my confusion, I found that Crane had left for China. Where was the money to bring the eminent Russian over here? I wrote to Mr. Crane's New York office, and found that he had made plans for Cholodkowsky before leaving. I explained Mr. Kent's offer and his departure for his health, and found that Crane's business man would advance the funds. I sent a full statement to Minister Morris and enclosed a photograph of the Russian professor to assist in identifying him. The money and the photograph were sent from the Swedish legation to an American consular agent, then temporarily posted at Riga. This agent took the matter up and eventually found Cholodkowsky. But the day that he was found, he died.

This was only one of a million tragedies of that period, but it seemed pretty close, and the American entomologists who know this story will always regret that Cholodkowsky could not have spent those last ten working years to which he looked forward, among us in America. 


\section{THE STORY OF AN ENTOMOLOGIST}

When "The Insect Menace" appeared, it was extensively reviewed in many newspapers, and, in fact, inspired a number of good editorials. I was rather annoyed to see that some of the writers, and indeed some of my correspondents, attributed a certain paragraph to me, whereas I had distinctly stated that the idea, and even the general phraseology, really originated with Dr. W. J. Holland, the distinguished entomologist and former director of the Pittsburgh Museum. I have just seen one of these rather annoying references in the "So They Say" pages in the January, 1932, number of The Golden Book, and it occurs to me that the whole story has never been told in print. Here it is:

A good many years ago I gave a lecture at the Pittsburgh Museum on the general subject of Insects, and I divelt for some time on the subject of the persistence of the insect type, calling attention to the fact that all those forms of life that depended upon great size, defensive armor and brute strength for existence had passed away, and that the type that had succeeded in perpetuating itself was one that depended rather on extremely small size, great powers of rapid multiplication, swiftness, cunning and powers of concealment.

I was Dr. Holland's guest, and after the lecture was over we returned to his beautiful home and sat down with our cigars and something to drink to talk it all over. From the depths of his easy chair, the dear Doctor said reflectively and very impressively, "Do you know, Howard, that idea that you stressed about the persistence of the insect type impressed me enormously. I quite agree with you. In fact, I verily believe that when the atmosphere will have become so rarefied that all of the higher animals and all of the flowering plants will have passed away, there, on the top of some dying lichen, chirk and smiling, will be one of your darned bugs."

I was immensely pleased with this and told him so. He was 


\section{FIGHTING THE INSECTS}

also pleased with it, and some years later introduced it in somewhat different words as a footnote in his famous "Butterfly Book."

Thus to Dr. Holland belongs the credit for this clever remark. In it he anticipated Maeterlinck, who wrote of insects as "our rivals here on earth and perhaps our successors."

I ended my fifty-three and a half years' service under Uncle Sam June 30, 1931. I had retired from the office of Chief of the Bureau October I, 1927, on account of the age limit fixed by Congress. But a welcome provision of the retirement law permitted me to stay on in the service with the title Principal Entomologist for two additional terms of two years each, which brought me to my seventy-fourth birthday.

The whole period of my official career was full of interest, and I led a thoroughly happy life. I was hardly conscious that I was working, since I was doing the things that I most wanted to do. I saw a great service built up, and as head of this service for more than thirty-three years many honors came to me. Not that I deserved them any more than a number of my associates. They were bestowed on me merely because I happened to be Chief. There were scholastic honors, for example, and I have quite a collection of doctorate diplomas. In fact, my dear friend Jablonowski of Budapest, who is very fond of his joke, begins his letters sometimes "My dear friend, Doctor of everything except Music and Divinity." Then, too, I have been made an honorary member of a large number of foreign societies and have had some medals and things of that kind. Possibly the most widely known of these was the Capper Award for 193r. This was the second time the Award had been made. In 1929 it was given to my old friend, Dr. S. M. Babcock of the University of Wisconsin, largely for his invention of the cream separator. The 


\section{THE STORY OF AN ENTOMOLOGIST}

terms of the Award read, "For distinguished services to Agriculture." That is virtually the same wording as that of the First Medal Award of the New York Farmers, which came to me in 1929. People sometimes smile when they hear or read of this last organization. There isn't a real old-fashioned farmer among them. They are nearly all prominent New Yorkers who own large estates and carry on some especial work like stock breeding and other things of that kind. Chauncey M. Depew was at one time its president. The organization gives dinners through the winter, and usually invites some well-known expert to address them. I have been told that in the old days they used to chaff the speaker, and I remember that once Logan Waller Page was asked to talk to them about good roads. He had been warned in advance and rather forestalled chaff by his opening remarks. He told me that he said on rising, "I am perfectly familiar with the character of this organization. I know of the great things that you have done for agriculture. To take only one example, I believe that your experiments in watering stock have been of enormous benefit to American agriculture."

The announcement of the Capper Award came during my last month in Washington, and although it was a great prize, it was only one of many gratifying things that happened during those last days. They gave me a big dinner at the Cosmos Club. At this there was room for men only, so a lot of the wives of members arranged another dinner for me, at which I was the only man present. Then came a letter from a stranger, Colonel Charles E. Davis of Honolulu, stating that he understood that I was going to France and inviting me to go to Europe via Honolulu and the western route as his guest, urging me, incidentally, to stay in Honolulu with him as long as I could. Naturally, I accepted, and began to make inquiries about my future host. One day I received a call at my office from a very 


\section{FIGHTING THE INSECTS}

charming young man who announced that he was Colonel Davis' son. He told me that his father was looking forward with great pleasure to my visit. Now, I am very fond of talking and as a wise, precautionary measure I said to the young man, "Is your father a good listener?" His face broke into a broad and irresistible smile, and he replied, "Doctor, tell my father that you asked me that question and that I refused to answer!"

Journeys around the world are so common nowadays that there is practically no feeling of adventure connected with them. Nevertheless, to me this journey was a perpetual delight. We went from New York down through the Panama Canal, and I spent rather more than three weeks with Colonel Davis in Honolulu. He proved to be a delightful man, with a fine mind and broad experience. It was a joy to meet my old colleagues in Honolulu and to see the results of their wonderful recent work. At the time of my visit, it seemed that the great pineapple industry would be saved from enormous damage by a virus carried by the pineapple mealy bug, thanks to a discovery that had just been made by a former assistant in the Bureau of Entomology, Dr. Walter C. Carter.

Going on from Honolulu, I, met entomologists at almost every stop: at Kobe, at Shanghai, at Hongkong, at Manila and at Colombo. It was a memorable journey.

In my last four years at Washington I had written and published two books. The first was a "History of Applied Entomology-More or Less Anecdotal," which the Smithsonian was good enough to bring out in 1930. It was a great pleasure to do this book, and the entomologists of the world have received it very cordially. The second was "The Insect Menace," published by the Century Company in 1931. My friend, Professor E. L. Bouvier of the Institut de France, has published a favorable review of this book and has arranged for its publication in the 


\section{THE STORY OF AN ENTOMOLOGIST}

French language by Flammarion. The translation is to be made by Monsieur L. Berland of the Natural History Museum.

I am writing these closing words at the end of July, 1932. I have been living in Paris with my youngest daughter for about nine months, and have enjoyed life here greatly. A large part of the time has been occupied in writing the preceding chapters. I have attended the meetings of some of the scientific societies, have hobnobbed with a number of prominent French entomologists and have made many new friends.

But the most important events of this stay in Paris have been the celebration of the one hundredth anniversary of the founding of the Entomological Society of France and the Fifth International Congress of Entomology that followed immediately after the Centenary celebration.

The latter was a very imposing function. A Séance Solennelle was held in the great amphitheater of the Museum of Natural History. The President of the Republic, who, by the way, is much interested in scientific matters, was present. The Minister of Public Health, Monsieur Godart, presided, and in the course of his address told us that he was the grandson of the famous French entomologist, Godart. Remarkable addresses were made by Professor E. L. Bouvier and Professor M. Caullery of Paris, and an admirable response in behalf of the visitors was made by Professor A. Lamerre of Brussels. Formal written addresses were handed in by delegates from many foreign societies and universities. The great hall was filled; scholastic gowns and hoods gave dignity and color; and the striking uniforms of the members of the Académie des Sciences gave a high touch to the picturesqueness of the scene. The formality and the official character of the celebration were emphasized by the presence of the uniformed Republican Guards, who, of course, always 


\section{FIGHTING THE INSECTS}

accompany the President of France on such occasions. On the stage with the dignitaries and the officers of the Society were seated the honorary members of the Society. I was thus admirably placed to see the great audience and the important figures on the stage, since I was made an honorary member as early as 1905 .

These Centenary exercises were held on Saturday, July i6th, and on Sunday, the delegates paid a visit to the tomb of Latreille, at Père-la-Chaise. He was the first Honorary President of the Society.

The Fifth International Congress began on Monday the 18th, and continued through the week. Dr. Paul Marchal was the President. But since these congresses are all rather similar, I shall not go into details here. It was, however, a distinct success. And this success is the more remarkable since the whole world is suffering an unprecedented financial blight. Many international congresses scheduled for this year have been postponed or abandoned. But the indomitable French entomologists carried this one through in a perfect manner. In spite of everything the attendance was large. Thirty-three countries were represented, and four hundred and sixty persons were registered. Had it not been for financial conditions, the attendance would probably have been so large it would have taxed the ingenuity and hospitality even of Paris, accustomed as it is to big functions. For example, I am sure that under normal conditions, hundreds of men would have come from America, instead of the forty-five who actually attended; for certainly, at the close of the very successful congress at Ithaca in August, 1928, almost every American there made up his mind positively to come to Paris in 1932. I know, for example, of one prominent American entomologist and his wife who went home and at once engaged an apartment with a French speaking family in order to practise 


\section{THE STORY OF AN ENTOMOLOGIST}

the French language for four years in anticipation of their trip to Paris. But, alas, when the time came they could not make the journey. Take my own old Bureau of Entomology, for another example. There should have been a large attendance from that institution. As it happened, not only could the government send no one over, but it allowed only two to come at their own expense, and these only because they had work to do during their absence from Washington in certain European museums.

During the Congress many important papers were read of especial interest to the world of entomologists, as was quite to be expected. President Marchal's address was very notable.

And now I must stop. I have written quite enough, and perhaps more than enough. My eyes have lasted well up to this time, but now I must go back to the United States for simple cataract operations on both eyes. I have led a long and happy life, and I have been very lucky to have been able to spend it all working in entomology. Surely the world knows a great deal more today about our rivals, the insects, than it did when I was a youngster. I am thankful that fate has given me a chance to see this great progress, and to watch it from the inside, and to be one of the workers. 



\section{Index}

Aberdeen, Lord, 219

Acker, George W., 54

Adams, C. K., 19

Adams, Charles Francis, 243, 275

Adams, Henry, 296

Agassiz, Louis, 6

Allwood, W. D., 72

American Association for Advancement of Science, $218 \mathrm{ff}$.

American Muscum of Natural History, 5 I

Amundsen, Roald, 28o

Anarchist, a so-called Italian, 136

Anopheles, Life history, first studied, II 8

Anopheles, the mating of, 136

Andrieff, I03, 104

Aphelinus mali, I Iо

Army worm, 33, 38, 44

Ashmead, W. H., 78

Asquith, Prime Minister, 202

Australian Lady-bird, 47, 48

Babcock, S. M., 320

Bachtisserai, I04

Bacon, Robert, 244

Bacteria, specificity of, 122

Balfour, A. J., 203

Bartlett, Paul Wayland, 259

Bass, C. C., $13 \mathrm{r}$
Bateson, William, 226, 227

Bat roosts and Mosquitoes, Grassi's views, 137

Beers, George D., I 4

Beggars in the Department, 37

Bell, Alexander Graham, $283 \mathrm{ff}$.

Berland, L., 323

Berlese, A., 93, 208

Béro, Victor, and his restaurant, 45, 46

Bessey, C. E., 247

Beutenmuller, William, 52

Bicknell, Ernest, 276

Bicycle, the old high, and bicycle clubs, $57,58,59$

Biederbeck, 280, 28I

Biggs, Herman P., I 4 I

Binder, C., 190

Bischoff, the blind organist, 61

Black, General, 36

Blaine, J. G., 6I

Blanchard, R., I 88 , I 89,242

Blastophaga grossorum, 310

Blue, Rupert, I30

Bolivar, I., 209

Bolivar y Peltain, C., 209

Boll Weevil, Cotton, 53, 68, 156

Borden, J. McK., 26

Bos, J. Ritsema, 192

Bourgeois, Léon, 194

Bouvier, E. L., 164, 322, 323 


\section{INDEX}

Boyce, Rubert, 127, 128

Bragina, Anna, ro8

Brancaccio, Principessa, 208

Bruce, Surgeon-Major, I 25

Bryan, W. J., 240

Bryce, James, 187, 255

Bureau of Entomology, rapid growth, I $56 \mathrm{ff}$.

Burgess, Edward, 37

Burleson, A. S., 69

Burnett, Swan R., 28 I

Busck, August, vi, 127

Butt, Archie, 247, 248

Butterfly Hunters, The, 3

Cabbage Butterfly, Imported, 7

Cabbage Butterfly, Native, 7

Caccini, A., 266, 267

Calimyrna figs, 3 I

Campbell, A. R., I 37

Cannon, Joe, 70

Capper Award, 320, 321

Carnegie, Andrew, 240

Carroll, J., I I9

Carruthers, Sir J., 2 I I, 2 I 2

Carter, Colonel and Mrs., 27

Carter, H. R., I 25

Carter, Walter C., 322

Cattell, J. McK., 64, 226

Caulfield, John P., 50

Caullery, M., 323

Cecropia Moth, 3

Celli, Angelo, I 3 I ff.

Centenary of Entomological Society of France, 324

Century Dictionary, 77

Chandler, William E., 70

Chapin, C. V., I 42 , I 43

Chief of Service, Appointment as, 52

Chilo oryzaeelus, 183

Chittenden, F. H., I I 7

Cholodkowsky, Nicolas, 316, 3I7, 3 I8

Choral Society, 50

Citrophilus mealy-bug, 92

Civil Service, in the old days, 35

Clark, Austin H., I68, 263
Clark, Dr., of Panama, I 25

Clark, I. Edwards, 305

Clarke, F. W., I63

Clifton, Dora C., first meeting, 50

Clover seed midge, 300, 301

Coccophagus gurneyi, 92

Columbian University, 53

Compere, George, I I 3

Compere, Harold, 92

Comstock, J. H., 7, 13, 32, 45

Congress hearings before committees, 67

Congressional incidents, $63,64,65$

Congressmen, few with college education in the $8 a$ 's, 62

Change in this respect in later years, 63

Convocation Week, 225

Cook, A. J., 52

Coquilett, D. W., 48

Cornell, A. B., I5

Cornell, Charles, I5

Cornell, Ezra, I6

Corn pone, 34

Corson, H., $2 \mathrm{I}$

Corydalis cornuta, 9

Cosmos Club, 253 ff.

Cotton Exposition, 45

Coues, Elliot, 54, 77, 79, 80

Covert, Mr., Consul at Lyons, I 47

Coville, F. V., 299

Cox, J. D., 61, 65

Crane, Charles R., 3 I 7

Crawford, F. S., 48

Credit to Assistants, 30

Cresson, E. T., 90

Crimean War Museum, I07

Curtis, George William, 36

Curtiss, Glenn, 287

Cushing, Frank, I I, I2

Dampf, A., I 78

Darwin, Charles, 194

Davenport, C. B., I

Davis, Charles E., $32 \mathrm{I}, 322$

Davis, J. J., I60 


\section{INDEX}

Davis, Watson E., 168

DeBussy, L. P., 268, 269

Delhi, N. Y., I

d'Herculais, Künckel, 195

Dillon, Marcel, 97

Doty, A. H., 241

Dugés, A., I 73

Dumont, Santos, 287

Dundundubia, $8 \mathrm{r}$

Dutton, C. E., 30

Dyar, H. G., I20, I 21,122

Edmunds, George F., 62

Egan, M. F., 273

Eisen, Gustav, 309

Eliot, Charles W., 227, 228

Encyclopedia, New International, 82

Ensenada, California, and Silk Culture, 153

Entomology and the War, 139

Evans, Fred, 75

Evans, Sir John, 220

Everett, Congressman, 70

Fabre, J. H., 97

Faellières, President, 194

Falconer, Sir R., 226

Farlow, W. G., 230, 23 I

Ferỏinand of Bulgaria, 270

Fermaud, G., 98

Fernald, C. H., 37

Fernow, B. E., 20, 305, 306, 307, 308

Field, H. H., ror

Finch, Francis M., 16

Finley, Carlos, i 8

Fiske, W. F., I I 3 , II 4

Fiske, Willard, I 9

Fitzgerald, John J., 70

Fletcher, James, 52, 290

Forestry School at Cornell Abolished, 20

Franz Joseph, I9I

Frew, R. Scott, 213

Frost, Charley, 7

Fujisawa, Professor, 217

Funston, General Frederick, 177,178
Gage, Phelps, 14, 15

Gage, S. H., 9, 14

Gage, Susanna Phelps, I4

Galloway, B. T., 157

Galtsoff, Paul, r 06

Garcia y Mercet, R., 209

Garfield, James R., 27, 38, 39, 235

Garland, Hamlin, 88

Gautier, Théophile, 99, I00, I01

Geikie, Sir A., 200

Geological Survey, U. S., 63,64

George Washington University, 56

Giard, A., I95

Gilman, Danicl C., 289

Gipsy Moth, 53, 155

Godart, Minister, 323

Gorgas, W. C., 124, 138

Graff, Dr, von, 196

Grassi, Battista, I 34 ff.

Greely, A. W., 220, 277

Greusel, J., I73

Grosvenor, G. B., 204

Haase, A., ${ }_{1} 38$

Hackett, L. W., 137

Hale, Edward Everett, 239

Hammond, John Hays, 223, 224

Handlirsch, A., 205

Harding, President, 249, 250, $25 \mathrm{I}$

Harrington, Mark W., 254

Harris, George William, 3, I9

Hawley, General Joe, 255

Hayes, President, Rutherford B., 233, 234

Hayes, Rutherford B., 60, 233, 234

Hellgrammite, 9

Heller, Dr., 94

Helmholz, Alexander, 255

Herms, Professor, I 39

Herrera, Alfonso, I73, I77

Herrick, G. W., 74

History of Applied Entomology, 322

Holland, W. J., 319, 320

Hollrung, Max, I 92

Holly Tree Inn, 75

Holmes, J. A., 5I 


\section{INDEX}

Hop plant-louse, $7 \mathbf{I}$

Horton, J. R., I60

Horvath, G., 194, 214, 275

Housefly, I $40 \mathrm{ff}$.

How, Wang, 212

Howard, Dr. Calvin, 2, 58

Howard, Frank, 4

Howard, George, 4

Howard, Jacob M., 2

Howard, Ossian Gregory, I

Howard, O. O., 2

Hubrecht, Professor, I 88

Hunter, W. D., 158

Huntsville, Alabama, 44

Hutchinson, R. H., I39

Hutchinson, Woods, I $_{4} \mathbf{I}$

Hutton, Lawrence, 277

Insect Life, The founding of the Journal, 47

Insect Menace, The, 322

Insects Injurious to Vegetation, 3

International Congresses, I 84 ff.

Ithaca Academy, 4

Ithaca Natural History Society, 3

Ivantcheff, Dr., of Bulgaria, I32

Jablonowski, J., 140

Jamaica, Long Island, N. Y., 3

Jefferson, Joseph, His place in Louisiana, 44

Jesup, Morris K., 5 I

Jordan, David Starr, 52, 2 II

Jusserand, Jules, 255, 298

Kean, J. R., I 23

Kelley, E. C., I60

Kelly, Henrietta Aiken, I 46

Kellogg, V., I 88

Kelvin, Lord, 219

Kent, William, 70, 273, 31 7

Kerosene against mosquito wigglers, II 7

Khan of the Crimea, Palace of, 104

Kiew, 102

King, A. F. A., 54
Kinne, William, and his school, 4

Kipling, Rudyard, 237

Kischiniew, 103

Knab, Frederick, 120

Koebele, Albert, 48, I 13

Krassiltschik, Isaak, I 03

Lamar, L. Q. C., 6I

Lamarck Fête, 194

Lamb, Congressman, 69

Lameere, A., 323

Lane, F. K., 224

Langley, S. P., 286

Lansing, Robert, 286

Laredo, Texas, Yellow fever outbreak, I 27

Lazaer, J. W., II9

LeDuc, William G., 312, 313, 3I4

Lefroy, H. M., 138

LePrince, J. A., 124

Lever, Congressman, I 79

Liceaga, E., I 75, 24I

Ligyrus rugiceps, 44

Ligyrus ruginasus, 44

Lippett, Francis J., 303

Lister, Lord, 219

Lockwood, Wilton, 86

Logan, John A., 62

Loring, George B., 38

Lowell, Augustus, 85

Lowell Institute, 84,85

Luna Moth, 5

Lundie, A. E., I 2

McBride, J. H., 62

MacCallum, A. B., 273

McClure, S. S., 58

McCoppin, Frank, 49

MacDowell, E. A., 229

McGee, J. W., 223, 224

Mackensen, Field Marshal, 270

McLaughlin, J. J., 223

Malaria and the Roman Campagna, I30, I3 I

Malaria carried by Mosquitoes, 53, 156

Malaria, in Ithaca and Washington, I 17 


\section{INDEX}

Mallory, Garrick, 30

Manley, C. M., 287

Manners, E. C., 64

Man of mystery, 314

Marchal, P., 93, 97, I 10, 209, 314, 315,324

Mark, E. L., I 8

Marlatt, C. L., I 17, I 80,182

Married life, 87

Matthews, Brander, 277

Maximoff, Mayor, 106

Medicine, early studies in, 53

Méline, M. de, 193

Merriam, C. Hart, 236, 240

Meyer, Frank, 294

Middleton, William, 139

Miller, Spencer, 292, 293

Millet, Frank, 258, 274, 275, 276, 277

Minot, C. S., 187,188

Mistral, the Provençal poet, 97

Mokrzecki, S., 93, 103

Montessori, Contessa, 287

Montornes, il Conde de, 209

Morley, Lord, 202

Morris, Ira Nelson, 318

Morse, E. S., 6

Morton, Sterling J., 52

Mosquitoes, Book on, II9

Mosquitoes, Carnegie Monograph, 120

Mosquitoes, early studies, I 16,117

Moulton, Dudley, 159

Mountmorris, Viscount, I 27, I 28

Muir, F., I I 3, I I 4

Müller, General, 103

Münsterberg, Hugo, I 26, I 86

Murray, Professor, 78

Music, Interest in, and temporary loss of interest in, 50

Nansen, Dr., 280, 281

National Academy of Sciences, 63,64

Navarro, L., 209

Negri, Signor, Grassi's assistant, 136

Newcomb, Simon, 126, 185, 186

Newman, L. J., I 13

New Orleans, 40, 41, 42, 45
New Orleans, Yellow fever outbreak, 127

Newspapers and Newspaper Men, I64, I 65

New York Farmers, $32 \mathrm{I}$

North, S. N. D., 294

Novy, F. G., I 66

Nuttall, G. H. F., I 4 I, I 43

Oberthür, René, and Charles, 96

Olive Fly, 208

Onteora Club, 86, 87, 88

Page, Logan Waller, $32 \mathrm{I}$

Page, Thomas Nelson, 297, 298

Parasites, commencement of study of, 90, 91,

Parasitic Flies, extraordinary work, 34

Parasitic Insects, First interest in, 33

Parker, H. L., I 39

Patten, Mrs. John D., 246

Pear Thrips, I 59

Peary, Admiral, 278

Pellagra, and Simulium, Grassi's views, 137

Pennell, Joseph, 59

Pergande, Theodor, 29, 72, 301

Perrier, Edmond, 194

Philadelphia Centennial, I I

Philharmonic Society, 50

Phillips, W. Hallett, 236, 237

Phylloxera, tracheal system of, I 7

Phytopathology, its proper meaning, 207

Pichler, A., I02, 190

Pickering, Charles, 2

Pickering, E. C., 2

Pickering, Lois, 2

Pieris rapae, 7

Pinchot, Gifford, 243, 244

Plotz, Harry, 269, 270

Pocock, R. A., 138

Poincaré, Henri, I 86

Pontia Oleracea, 7

Porchinski, 93, I0 I

Portsmouth, Virginia, 33 


\section{INDEX}

Pospelow, Valdimar, 102

Poulton, E. B., 78, 204, 307

Poutiers, R., I I 2

Poverty called Blessed, 52

Powell, Harold, 96

Pratt, F. C., 3I, 32

Prentiss, D. W., 54

Prentiss, Professor, 21, 22

Proctor, John R., 36

Promethia Moth, 3

Putnam, Herbert, 297

Quick, Herbert, 27 I

Quincy, Josiah, 229

Rayleigh, Lord, 200

Rebel, F., 94

Reed, Walter, I I 8

Reed, Walter, Memorial started, 289

Remsen, lra, I63, 239

Rice Insects, 39

Rice Stem-Borer, I 83

Riley, C. V., 6, 7, 13, I 7, 18, 29, 30, $38,47,52$, I $13,145,195,303$

Ritter, W. E., I 67

Robinson, James Harvey, 295

Rockford, Illinois, I.

Roeding, George C. 308

Roosevelt, Theodore, 235 ff., 340, 34 I

Rose, Dr. (Rockefeller Foundation), I 3 I

Rosenau, M. J., I 77

Ross, Ronald, 53, I 26, 127

Royal Society of Canada, Lecture before, I 24, I 25

Royal Society of England, I97 ff.

Rühl, Marie, Io I

St. Botolph Club, 85

Sagnier, H., 210

San José Scale, 53, I 55

Saratoga Races, I I

Schizoneura lanigera, 109

Schlöpfer, E., ro I

School Histories, I 75, I 76
Schurman, J. G., I9, 20

Schurz, Carl, 6I

Schwarz, E. A., 44, 276, 310

Science Service, I67, I68

Scientific Names, 44

Scriven, Colonel John, 39

Scudder, S. H., 7, 52

Seabra, A. de, 209

- Seaman, L. L., I65

Sedgwick, W. T., 84

Seeley, L. Warren, and one of his poems, 59

Semple, Miss Ellen, 309

Serrell Silk Reel, I 45

Serriterre, California, I53

Severin, A., 275

Sewell, R. V. V., 274

Sharp, David, 197

Sherman, Harry, 50

Shipley, Sir Arthur, 138, 196, 197, 198

Siepi, Dr., 97

Silk Culture, 44 ff.

Silk Culture Manual, 29

Silvestri, F., 93, I35

Simferopol, 104

Simmons, Dr., I 43

Simpson, C. B., 160

Skierniewice, Poland, Io8

Slosson, E. E., ${ }^{6} 67$

Small, Congressman, 70

Smith, Benjamin E., 78

Smith, Goldwin, Io

Smith, H. H., 78

Smith, Harry Scott, 92

Smith, John B., 3 I

Smith, Roland Cotton, 297

Smyrna Fig story, 308, 309, 310

Standard Dictionary, 82

Sternberg, George M., I 9

Stiles, C. W., 242

Stimson, Henry L., 2

Stockton, Frank R., 282

Strong, Lee, I 82

Sugar Cane Insects, 43, 44

Summers, J. N., I 09

Swingle, Walter T., 309 


\section{INDEX}

Taft, William H., 2, 245, 246, 247

Taylor, Dr. J. M., 82

Temple, Dr. H. W., 70, $31 \mathrm{I}$

Thayer, Dr. W. S., I 18 , 126

Thompson, J. Ford, 54

Thompson, W. J., 43

Thurber, A. G., 26

Thurber, F. B., 25

Thurber, H. K., 25

Thurber, Lucy Dunham, I

Tillyard, R. J., I13, 302

Tiraboschi, Dr., 132

Tisserand, M., 193

Townsend, Congressman, 7I

Treat, Mrs. Mary, 3

Trenholm of the Treasury, Anecdote of, 37

Tsetse fly, 125

Typhoid Epidemic in Ithaca, 20

Ulke, Henry, 37, 44

Vail, Dr., I3 I

Van Dine, D. T., I 39

Vassar College, 82,83

Vayssière, P. 97, II I

Vedalia (or Novius) cardinalis, 49

Voguë, Marquis de, 193

Vorhees, Senator, 62

Vuillet, André, 96

Vuillet, Madame, 96

Wadsworth, James, 67

Wageningen Conference, 206

Wagner, F., 94

Walker, Philip, I 45

Wallace, Alfred Russell, 303, 304

Wallace, Henry C., 25I

Ward, Marshall, 307, 308

Washington, Henry S., 259, 263
Washington in the early 80 's, 6o, 61

Waters, Theodore, 167,229

Watrous, R. D., 276

Weber-Vitali Silk Reel, 152

Webster, F. M., 48

Welch, W. H., I 25,238

West, H. L., I 89

Westwood, J. O., 205

Wheeler, Candace, 3

Wheeler, W. M., 52

White, Andrew D., Io, I9

White, Dr. J. H., I 28

White, Fred, I6

White, Henry, 243

Wickersham, G. W., 246

Wigmore, J. H., 274

Wilder, B. G., I4

Wildermuth, V. L., 158

Wiley, H. W., 221, 257, 310, 311

Wiley, W. H., 310, 31 I

Wilkinson, Guy, I 53

Williams, John Sharp, 67

Williston, S. W., $5 \mathrm{I}$

Wilson, James, $145, \mathrm{I} 80,189,208,3$ I 2

Wilson, Woodrow, 248, 249

Windsor Castle, Reception at, 203

Wives of scientific men, 88,89

Wood, Mary Knight, I 75

Woolly Aphis of the Apple, III

Wyman, Walter, $24 \mathrm{I}$

Yellow Fever Mosquito at St. Louis, 127

Young, Archibald, 213

Youth's Companion, 76

Zaharoff, Sir Basil, 314

Zort, Dr., 216

Zyxomma, 8o 


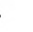




